\title{
Naar een employability monitor
}

\author{
Citation for published version (APA):
}

de Grip, A., \& Sanders, J. M. A. F. (2000). Naar een employability monitor. Researchcentrum voor Onderwijs en Arbeidsmarkt, Faculteit der Economische Wetenschappen. ROA Reports No. 9 https://doi.org/10.26481/umarep.2000009

Document status and date:

Published: 01/01/2000

DOI:

10.26481/umarep.2000009

Document Version:

Publisher's PDF, also known as Version of record

\section{Please check the document version of this publication:}

- A submitted manuscript is the version of the article upon submission and before peer-review. There can be important differences between the submitted version and the official published version of record.

People interested in the research are advised to contact the author for the final version of the publication, or visit the DOI to the publisher's website.

- The final author version and the galley proof are versions of the publication after peer review.

- The final published version features the final layout of the paper including the volume, issue and page numbers.

Link to publication

\footnotetext{
General rights rights.

- You may freely distribute the URL identifying the publication in the public portal. please follow below link for the End User Agreement:

www.umlib.nl/taverne-license

Take down policy

If you believe that this document breaches copyright please contact us at:

repository@maastrichtuniversity.nl

providing details and we will investigate your claim.
}

Copyright and moral rights for the publications made accessible in the public portal are retained by the authors and/or other copyright owners and it is a condition of accessing publications that users recognise and abide by the legal requirements associated with these

- Users may download and print one copy of any publication from the public portal for the purpose of private study or research.

- You may not further distribute the material or use it for any profit-making activity or commercial gain

If the publication is distributed under the terms of Article $25 \mathrm{fa}$ of the Dutch Copyright Act, indicated by the "Taverne" license above, 


\title{
Naar een Employability Monitor
}

\author{
ROA-R-2000/9
}

Andries de Grip

Jos Sanders

\author{
Researchcentrum voor Onderwijs en Arbeidsmarkt \\ Faculteit der Economische Wetenschappen en Bedrijfskunde \\ Universiteit Maastricht \\ Maastricht, november 2000
}


ISBN 90-5321-291-4

Sec00116/JS 


\section{Inhoud}

Voorwoord

Resumé

1 Inleiding 1

2 Het raamwerk voor de opzet van de Employability Monitor $\quad 7$

$\begin{array}{ll}2.1 & \text { Employability model voor werknemers }\end{array}$

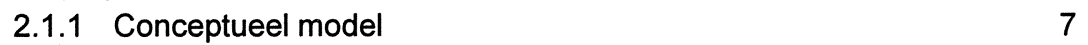

2.1.2 Individuele employability van werknemers 9

$\begin{array}{ll}2.1 .3 & \text { Behoefte aan employability } \\ 2.15\end{array}$

$\begin{array}{ll}2.1 .4 \text { Arbeidsmarktperspectieven } & 18\end{array}$

$\begin{array}{ll}2.1 .5 & 19\end{array}$

2.2 Employability model voor niet-werkenden 23

2.2.1 Conceptueel model 23

2.2.2 Individuele employability van niet-werkenden 26

$\begin{array}{ll}2.2 .3 \text { Arbeidsmarktperspectieven } & 30\end{array}$

$\begin{array}{ll}2.2 .4 & \text { Effectueringscondities }\end{array}$

3 Inventarisatie van bruikbare databronnen 33

3.1 Inventarisatie beschikbare databronnen 33

3.2 Inventarisatie naar employability-dimensie 44

3.2.1 Bruikbare databronnen voor de Employability Monitor voor werknemers

3.2.2 Bruikbare databronnen voor de Employability Monitor voor niet-werkenden

4 Een eerste invulling van de Employability Monitor: werknemers 57

4.1 Individuele employability van werknemers $\quad 57$

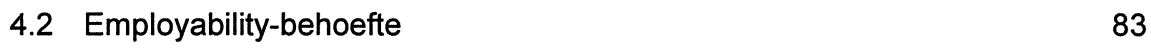

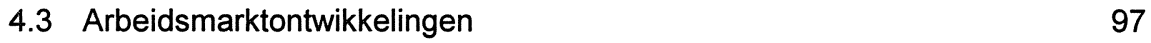

$\begin{array}{lr}4.4 \text { Effectueringscondities } & 101\end{array}$

5 Een eerste invulling van de Employability Monitor: niet-werkenden $\quad 117$

$\begin{array}{ll}5.1 & \text { Individuele employability van niet-werkenden } \\ 5.2117\end{array}$

5.2 Arbeidsmarktperspectieven van niet-werkenden 136

$\begin{array}{ll}5.3 \text { Effectueringscondities } & 138\end{array}$

6 Employability Index 143

6.1 Sectorale Employability Index voor werknemers 143

6.2 Employability Index voor niet-werkenden 157

7 Verdere ontwikkeling van de Employability Monitor 167

$\begin{array}{ll}7.1 \text { Lacunes in de beschikbare informatie } & 167\end{array}$

$\begin{array}{ll}7.2 & \text { Naar een periodieke Employability Monitor } \\ & 167\end{array}$ 
Appendix A Inventarisatie van de belangrijkste aandachtspunten 


\section{Voorwoord}

In dit rapport wordt verslag gedaan van een in opdracht van het Ministerie van Sociale Zaken en Werkgelegenheid door het Researchcentrum voor Onderwijs en Arbeidsmarkt (ROA) uitgevoerde studie naar de haalbaarheid van een nationale Employability Monitor. De studie werd uitgevoerd in het kader van de in 1999 door het kabinet en de sociale partners opgezette Employability Agenda.

Centrale doelstelling van deze studie is allereerst het beoordelen van de mogelijkheden om een periodieke Employability Monitor in te richten. Bovendien wordt in deze studie bekeken met welke frequentie een dergelijke monitoring het beste zou kunnen plaatsvinden en welke databronnen op dit moment de meest geëigende zijn om in de monitor op te nemen. Ten slotte wordt aandacht besteed aan de huidige lacunes in de datavoorziening en de mogelijkheden om deze op te vullen door aanpassingen in bestaande enquêtes of het inrichten van nieuwe enquêtes.

De haalbaarheidsstudie is als volgt opgebouwd: Allereerst is op basis van enerzijds bestaande theorievorming in wetenschappelijke en vakliteratuur en anderzijds een aantal gesprekken 'in het veld' een beeld geschapen van wat 'employability' nu eigenlijk betekent voor bedrijven, overheid en de sociale partners. Ook is aandacht geschonken aan employability in een internationaal perspectief, door in gesprek te gaan met het Britse Skills Task Force. In appendix A van deze rapportage zijn de belangrijkste bevindingen van deze wat meer kwalitatieve studie weergegeven.

In het tweede hoofdstuk worden vervolgens twee conceptuele modellen gepresenteerd, die het raamwerk vormen voor de Employability Monitor voor werkenden en de Employability Monitor voor niet-werkenden. Voor deze tweedeling is gekozen omdat employability voor werkenden een wat andere betekenis heeft dan voor nietwerkenden. Voor de werkenden ligt immers het accent op het behoud van werk, voor de niet-werkenden op het verkrijgen van werk.

Met de beide conceptuele modellen als leidraad is vervolgens nauwkeurig gekeken in hoeverre er met bestaande databronnen invulling kan worden gegeven aan de beide Employability Monitoren. In hoofdstuk 3 wordt hiertoe een groot aantal databronen besproken, elk gescand op mogelijk interessante data. Uiteindelijk blijken met name de Enquête Beroepsbevolking, het OSA-Aanbodpanel, de OSA-Vraagsurvey, het Hoe Zoeken Werkzoekenden-bestand en de Intemational Adult Literacy Survey een belangrijke bijdrage te kunnen leveren aan de invulling van de beide monitoren.

In de hoofdstukken 4 en 5 wordt vervolgens met behulp van deze en enkele andere databronnen een eerste invulling gegeven aan de Employability Monitor voor werkenden (hoofdstuk 4) en de Employability Monitor voor niet-werkenden (hoofdstuk 5). Bovendien wordt in deze beide hoofdstukken per indicator aangegeven in hoeverre op dit moment de benodigde data beschikbaar zijn, of in de toekomst mogelijk kunnen worden vergaard. 
De afzonderlijke gegevens die in de hoofdstukken 4 en 5 de revue passeren komen in hoofdstuk 6 samen in een aantal verschillende indices, waarvan de Sectorale Employability Index voor werkenden en de Employability Index voor niet-werkenden als sluitstuk dienen. Deze beide overall-indices hebben overigens niet de intentie een waarde-oordeel te geven over de employability-situatie voor bepaalde groepen mensen, maar zijn veel meer bedoeld ter signalering van mogelijke aandachtspunten voor het employability beleid. De Sectorale Employability Index geeft de employability-situatie weer op zowel het lage aggregatieniveau van 35 bedrijfssectoren als het hoge aggregatieniveau van 13 bedrijfssectoren. De Employability Index voor nietwerkenden geeft de employability-situatie weer voor een vijftal categorieën niet-werkenden, verbijzonderd naar 5 opleidingsniveaus.

In hoofdstuk 7 wordt ten slotte een overzicht gegeven van de lacunes in de datavoorziening op dit moment. Bovendien wordt een aantal aanbevelingen gedaan om tot een periodieke Employability Monitor te komen, voor zowel werkenden als niet werkenden. Een van de meest in het oog springende zaken daarbij is de noodzaak een competentie-enquête op te zetten. Ook wordt geconcludeerd dat het beste kan worden gekozen voor een tweejaarlijkse monitor, met tussentijdse rapportages waarin aandacht wordt besteed aan specifieke actuele thema's.

De projectleiding van dit onderzoek was in handen van Prof.dr. A. de Grip. Drs. J.M.A.F. Sanders speelde een centrale rol bij de uitvoering van het onderzoek en de totstandkoming van de rapportage. Aan het rapport is verder meegewerkt door S. Dijksman, R. Leclercq en drs. A.M.G. Jacobs. Onze dank gaat bovendien uit naar de leden van de begeleidingscommissie bij het Ministerie van Sociale Zaken en Werkgelegenheid, te weten: drs. H. Fekkes, drs. S. Pulleman, drs. L. Schrijver, drs. J.Timmerman, drs. F. Straatjes en drs. L. Bastiaansen en namens het Ministerie van Economische Zaken: drs. J. Beeftink.

Ten slotte willen wij de volgende mensen bedanken voor hun inbreng: Dr. D. de Gilder en Prof.dr. J.P. van den Toren, werkzaam bij de werknemersvereniging CNV, W. van der Meulen en Ing. J.M.G. Muijsers MA, beiden werkzaam op de afdeling personnel recruitment \& transfer van DSM, W.J.M. Berentzen en drs. Th. van den Hoven werkzaam bij branchevereniging FME/CWM, drs. J.W. Koole, werkzaam als secretaris onderwijszaken bij VNO/NCW, T. Hooijmans s.s.t.t., werkzaam als stafdirecteur HRM bij Cap Gemini en drs. M. van Smoorenburg, werkzaam bij Arbeidsvoorziening Limburg. 


\section{Resumé}

In Naar een Employability Monitor wordt verslag gedaan van de door het Researchcentrum voor Onderwijs en Arbeidsmarkt in opdracht van het Ministerie van Sociale Zaken en Werkgelegenheid uitgevoerde haalbaarheidsstudie voor het opzetten van een Employability Monitor. Het opzetten van deze Employability Monitor is een van de onderdelen van de in 1999 opgestelde Employability-agenda van het kabinet en de sociale partners. Centrale doelstelling is het verkrijgen van inzicht in de verschillende aspecten van de ontwikkeling van employability van de Nederlandse potentiële beroepsbevolking en de behoefte aan verdere investeringen in de employability van werkenden en niet-werkenden.

Employability wordt hier opgevat als het vermogen en de bereidheid van mensen om werk te krijgen en te houden (Ministerie van Onderwijs, Cultuur en Wetenschappen 1998). Deze definitie richt zich enerzijds op de potentiële beroepsbevolking en anderzijds op werkgevers en overheid. Tot de potentiële beroepsbevolking behoren werkenden, niet-werkende werkzoekenden en niet-participerenden. De rol van de werkgevers en de overheid (zowel in de rol van wetgever als in de rol van werkgever) is met name een voorwaardenscheppende c.q. faciliterende rol.

De haalbaarheidsstudie is stapsgewijs opgebouwd. Hierbij gaat het achtereenvolgens om de volgende zes stappen:

- inventarisatie van de wensen met betrekking tot de monitor;

- ontwikkeling en inrichting van de eerste opzet van een employability monitor;

- inventarisatie van de beschikbare databronnen;

- invulling geven aan de eerste opzet met gebruikmaking van de beschikbare data;

- inventarisatie van gegevens die weliswaar van belang zijn, maar (nog) niet beschikbaar;

- doen van voorstellen om te komen tot een optimale inrichting van de periodieke Employability Monitor.

\section{Wensen}

In een aantal gesprekken met Human Resource Managers (HRM) van verschillende grote ondernemingen, vertegenwoordigers van werkgevers en werknemersorganisaties als CNV, VNO/NCW, vertegenwoordigers van Arbeidsvoorziening en het Britse National Skills Task Force zijn de relevante aandachtspunten voor een Employability Monitor geïnventariseerd. Uit de gesprekken bleek dat rondom het thema employability met name over het belang van functioneringsgesprekken, opleidingsen ontwikkelingsplannen, competentiemanagement en het stimuleren van doorstroom een brede consensus bestaat.

\section{Conceptuele modellen}

In hoofdstuk 2 worden twee conceptuele modellen gepresenteerd: één voor werkenden en één voor niet-werkenden. Voor deze tweeledige aanpak is gekozen omdat voor de employability van werkenden andere aspecten van belang zijn dan voor 
de employability van niet-werkenden. Bij employability van werkenden ligt de nadruk op het blijven werken van werkenden. Bij de employability van niet-werkenden gaat het meer om het vermogen en de wil om aan werk te komen. Dit onderscheid vraagt om een aparte benadering van beide groepen. Hoewel de dimensies van beide modellen grotendeels dezelfde zijn, verschillen zij qua invulling.

\section{Werkenden}

Het model voor de Employability Monitor van werkenden kent vier dimensies, te weten:

- individuele employability;

- sectorale behoefte aan employability;

- arbeidsmarktontwikkelingen;

- effectueringscondities.

De individuele employability van werkenden wordt bepaald aan de hand van gegevens over hun vermogens, bereidheid, inspanningen en persoonlijke belemmeringen. De sectorale behoefte aan employability wordt in beeld gebracht door te kijken naar een viertal maatschappelijke ontwikkelingen en de mate waarin deze ontwikkelingen binnen de verschillende bedrijfssectoren een rol spelen. Bovendien wordt gekeken naar de arbeidsomstandigheden. De arbeidsmarktontwikkelingen worden in kaart gebracht door te kijken naar de arbeidsmarktperspectieven van de werkenden in de verschillende bedrijfssectoren op de middellange termijn ( 5 jaar). De effectueringscondities worden ten slotte in kaart gebracht door te kijken naar institutionele en fiscale maatregelen, bijvoorbeeld bepalingen in CAO's, faciliteiten gericht op de employability van werkenden, de bekendheid van werknemers met de bestaande faciliteiten en hun kennis van de arbeidsmarkt. De vier dimensies bepalen tezamen de employability van de werkenden in een bedrijfssector.

\section{Niet-werkenden}

Het model dat is geconstrueerd voor de niet-werkenden is opgebouwd uit een drietal dimensies, namelijk:

- individuele employability;

- arbeidsmarktontwikkelingen;

- effectueringscondities.

De individuele employability van niet-werkenden wordt eveneens bepaald aan de hand van hun vermogens, bereidheid, inspanningen en persoonlijke belemmeringen. Hierbij staan, anders dan bij werknemers, het intredevermogen, de intredebereidheid en de geleverde intrede-inspanningen centraal. Bij het in beeld brengen van de arbeidsmarktperspectieven van niet-werkenden met een bepaalde opleidingsachtergrond wordt gekeken naar de perspectieven op de korte termijn. Daarbij wordt 1 jaar vooruit gekeken. $\mathrm{Bij}$ de effectueringscondities is eveneens een iets andere invalshoek gekozen dan dat bij werknemers het geval was. Weliswaar wordt uitgegaan van dezelfde drie variabelen - institutioneel en fiscaal kader, faciliteiten en communicatie - maar de variabelen worden op een andere wijze geoperationaliseerd, doordat met 
name wordt gekeken naar wetten en maatregelen die gericht zijn op het bespoedigen van de intrede van groepen niet-werkenden. Reïntegratietrajecten en wettelijke en fiscale maatregelen ter bevordering van de deelname aan het arbeidsproces van specifieke doelgroepen staan hierbij centraal.

\section{Bruikbare databronnen}

In hoofdstuk 3 wordt een inventarisatie gepresenteerd van de meest interessante, op dit moment beschikbare databronnen bij het in beeld brengen van de employability van werkenden en niet-werkenden. De databronnen die zijn onderzocht op hun relevantie voor de Employability Monitor, zijn:

- OSA-Aanbodpanel (OSA);

- OSA-Vraagpanel (OSA);

- Enquête Beroepsbevolking (CBS);

- Sociaal Economisch Panelonderzoek (CBS);

- Continuing Vocational Training Survey (CBS/Eurostat);

- Schoolverlaters Informatie Systeem (ROA);

- International Adult Literacy Survey en International Life Skills Survey (OECD);

- SZW-Werkgeverspanel (SZW);

- Arbeidsverhoudingen-survey (TNO-arbeid);

- De Arbeidsmarkt naar Opleiding en Beroep (ROA);

- Werkzoekendenbestand (Arbeidsvoorziening/CWI);

- CAO-Inventarisatie (Arbeidsinspectie);

- Hoe Zoeken Werkzoekenden en Hoe Zoeken Ingeschrevenen (Arbeidsvoorziening/Research voor Beleid).

Afhankelijk van de steekproefgrootte en de variabelen die met bepaalde databronnen in beeld kunnen worden gebracht, is nagegaan in hoeverre een databron geschikt is voor de monitoring van employability. De Enquête Beroepsbevolking komt daarbij naar voren als de databron met de meeste gebruiksmogelijkheden bij het meten van de individuele employability, aangevuld met gegevens uit het OSA-Aanbodpanel en de International Adult Literacy Survey. Voor het bepalen van de individuele employability van de werkzoekenden zijn het 'Werkzoekendenbestand' en het 'Hoe Zoeken Werkzoekenden-bestand' overigens ook geschikte bronnen. Om de behoefte aan employability van werknemers in beeld te brengen is de OSA-Vraagsurvey het meest geschikt, aangevuld met de Enquête Beroepsbevolking. Arbeidsmarktontwikkelingen kunnen voor zowel werkenden als niet-werkenden het beste in beeld worden gebracht door gebruik te maken van de tweejaarlijkse ROA-studie De Arbeidsmarkt naar Opleiding en Beroep. Voor het in beeld brengen van de effectueringscondities kan gebruik worden gemaakt van een groot aantal verschillende bronnen. De CAOInventarisatie en het OSA-Vraagpanel zijn hierbij de meest interessante databronnen waar het de werknemers betreft. Voor de niet-werkenden is nog geen databron beschikbaar die informatie levert over de mate waarin maatregelen of trajecten worden gebruikt. Wel is een inventarisatie van beschikbare middelen mogelijk op basis van verschillende notities en wetteksten. Met gebruikmaking van de meest bruikbare 
databronnen is in hoofdstuk 4 voor werkenden en in hoofdstuk 5 voor niet-werkenden een eerste opzet van de Employability Monitor gepresenteerd.

\section{De eerste opzet van een Employability Monitor voor werkenden}

In hoofdstuk 4 wordt met gebruikmaking van data uit de verschillende bronnen een eerste invulling gegeven aan de Employability Monitor volgens het in hoofdstuk 2 gepresenteerde raamwerk. Dit levert een redelijk volledig beeld op van de employability van werkenden. De belangrijkste lacunes in de beschikbare data liggen op het gebied van de individuele employability, waarbij met name de informatie over competenties ontbreekt. Bovendien is geen geschikte informatie gevonden om inzicht te verschaffen in het vermogen en de bereidheid van werkenden tot een brede kwantitatieve inzet (in staat zijn op onregelmatige tijden te werken, overuren te maken en in wisselende diensten te werken), het vermogen tot een brede kwalitatieve inzet (in staat zijn uiteenlopende functies te bekleden), de inspanningen op het gebied van kwantitatief brede inzet en het al dan niet hebben van een arbeidshandicap. De sectorale behoefte aan werkenden met een goede employability als gevolg van technologische veranderingen, is slechts beperkt te meten en de mate waarin werknemers op de hoogte zijn van de beschikbaarheid van faciliteiten gericht op de versterking van hun employability zijn eveneens niet goed te bepalen met de momenteel beschikbare databronnen.

\section{De eerste opzet van een Employability Monitor voor niet-werkenden}

In hoofdstuk 5 wordt een eerste invulling gegeven aan de Employability Monitor voor niet-werkenden. Voor een dergelijke monitor bestaat er echter een groot aantal lacunes in de beschikbare informatie. Niet alleen is het vooralsnog onmogelijk de nietparticiperenden te verbijzonderen naar niet-participerenden met een werkende partner. Ook is het als gevolg van in de verschillende databronnen gebruikte routings voor een aantal variabelen moeilijk de niet-werkende werkzoekenden te onderscheiden van de personen die in het geheel niet participeren op de arbeidsmarkt. Veel van de lacunes kunnen in de toekomst met data uit de Enquête Beroepsbevolking worden opgevuld. Andere lacunes, bijvoorbeeld bij het in beeld brengen van competenties of de bekendheid van niet-werkenden en werkgevers met bestaande regelingen en trajecten, zijn niet zo eenvoudig op te vullen.

\section{Employability Index}

In het zesde hoofdstuk komen vrijwel alle resultaten van hoofdstuk 4 samen in een Sectorale Employability Index. De index maakt duidelijk dat de sectoren Bank- en verzekeringswezen en Kwartaire diensten er het beste voorstaan als wordt gekeken naar de individuele employability van de werkenden, de sectorale behoefte aan employability, de arbeidsmarktontwikkelingen en de effectueringscondities. De sec- 
toren Landbouw en visserij, Overige industrie en Transport en communicatie staan er daarentegen het minst gunstig voor ${ }^{1}$.

Ook is in hoofdstuk 6 getracht een Employability Index te construeren voor de nietwerkenden. Als gevolg van de beperkte beschikbaarheid van data en de slechte vergelijkbaarheid van de wel beschikbare data zijn de weergegeven indices voor met name de niet-participerende vijftigplussers en de niet-participerenden met een arbeidshandicap echter weinig informatief.

\section{Verdere ontwikkeling van de Employability Monitor}

In het laatste hoofdstuk van deze rapportage wordt de conclusie getrokken dat een Employability Monitor zeker haalbaar is, zij het dat de dataverzameling structureel zal moeten zijn. Dat wil zeggen dat de opvulling van de gevonden lacunes in de datavoorziening plaats dient te vinden binnen het kader van bestaande databronnen waarvan het voortbestaan in ieder geval voor de komende jaren vast staat. Met name voor de niet-participerenden zou er op die manier meer informatie moeten worden verzameld. De Employability Monitor zou bovendien moeten worden verrijkt met meer gegevens over de competenties waarover werkenden en niet-werkenden beschikken (vakspecifieke expertise, communicatieve vaardigheden, ICT-skills, e.d.). Hiervoor zou een Competentie Enquête opgezet moeten worden. In een dergelijke Competentie Enquête kunnen de competenties waarover mensen beschikken nauwgezet in kaart worden gebracht. Daarnaast kan worden gevraagd naar de competenties die vereist zijn voor de functie die men uitoefent, de vereiste inwerktijd, de mate waarin technologische en organisatorische vernieuwingen van invloed zijn op de vereiste competenties, de deelname aan trainingen, het salaris, het risico op verlies van werk, e.d.

De Employability Monitor voor werkenden zoals die nu wordt gepresenteerd, is slechts een dwarsdoorsnede van de employability van de werkenden in de verschillende bedrijfssectoren. Wanneer er meer inzicht in de employability van individuen zou moeten worden verkregen dan zou gedacht kunnen worden aan het opnieuw benaderen van het SMVO-cohort ${ }^{2}$ van het CBS. Dit zou een fraai longitudinaal databestand opleveren op basis waarvan een goed beeld van de relaties tussen capaciteiten, motivatie en attitudes, loopbaanontwikkeling en employability zou kunnen worden verkregen.

Ten slotte wordt voorgesteld de Employability Monitor tweejaarlijks uit te voeren omdat een aantal belangrijke databronnen tweejaarlijks beschikbaar is (OSA-Aanbod- en -Vraagpanel). Bovendien mag ook verwacht worden dat er op de meeste

1. Deze resultaten volgen uit het ongewogen samennemen van alle verschillende employability-aspecten. Hiermee is niet gezegd dat een sector er slecht voorstaat, enkel dat een aantal aspecten mogelijk bijzondere aandacht vragen.

2. SMVO staat voor Sociaal Milieu Voortgezet Onderwijs. Dit cohort is in 1977 opgezet om informatie over de schoolloopbaan van leerlingen die in het voortgezet onderwijs starten te verzamelen. Het cohort is gevolgd tot 1987. 
aspecten van de employability van werkenden en niet-werkenden in één jaar geen grote veranderingen optreden.

Daarbij zou de monitor zowel de beschikbare informatie over de verschillende aspecten van de employability van werkenden en niet-werkenden in beeld moeten brengen, als twee samenvattende indexcijfers moeten presenteren: de Sectorale Employability Index en de Employability Index Niet-werkenden. Eventueel zou ook een verdere verbijzondering mogelijk zijn, zodat ook indices kunnen worden samengesteld voor niet-werkende werkzoekenden, niet-participerende vijftigplussers en niet-participerenden met een arbeidshandicap. In deze rapportage is getracht deze verbijzondering al te maken, maar de beperkte aanwezigheid van data maakt dat met name de laatste twee indices nog onvoldoende betrouwbaar zijn. Om te bewerkstelligen dat de Employability Monitor zich ontwikkelt tot een aansprekende rapportage, is het belangrijk dat de veelheid aan cijfers die wordt gepresenteerd, wordt aangevuld met kwalitatieve informatie en eventuele op een bepaald aspect van de employability van werkenden of niet-werkenden toegespitste analyses. Het zou de helderheid en informatieve waarde van de rapportage daarbij ten goede komen, wanneer onderliggende tabellen in een bijlage worden opgenomen en de hoofdtekst enkel bestaat uit de belangrijkste conclusies en eventueel aanvullend kwalitatief materiaal.

Bij een tweejaarlijkse actualisering van de Employability Monitor bestaat de mogelijkheid in het tussenliggende jaar nader onderzoek te doen naar specifieke aspecten van de employability van werkenden en niet-werkenden. Ook zou er in het tussenliggende jaar onderzoek kunnen plaatsvinden in de vorm van specifieke case-studies. Deze case-studies zouden moeten worden gericht op specifieke thema's die blijkens de Employability Monitor extra aandacht behoeven. Op deze manier zou nader invulling kunnen worden gegeven aan specifieke aspecten van de employability van werkenden of niet-werkenden. Met de resultaten van het onderzoek dat in dit tussenliggende jaar plaatsvindt kan de nieuwe rapportage van de Employability Monitor in het daaropvolgende jaar weer verrijkt worden. 


\section{Inleiding}

In het kader van de door het kabinet geïnitieerde employability-agenda is door het Ministerie van Sociale Zaken en Werkgelegenheid het voortouw genomen voor het opzetten van een Employability Monitor. In dit rapport wordt verslag gedaan van een vooronderzoek gericht op de ontwikkeling van een monitor voor de employability van de (potentiële) beroepsbevolking en het employability-beleid van bedrijven, instellingen en overheidsinstanties. Employability wordt hierbij opgevat als het 'vermogen en de bereidheid van mensen om werk te krijgen en te houden' (Ministerie van Onderwijs Cultuur en Wetenschappen, 1998). Daarbij gaat het om het verwerven en onderhouden van capaciteiten die mensen in staat stellen optimaal te reageren en te anticiperen op de voortdurend veranderende arbeidsmarkt.

Ten minste drie schaalniveaus zijn blijvend relevant bij de systematische analyse van employability als concept en bij de voorbereiding van systematisch empirisch onderzoek naar employability als verschijnsel in de werkelijkheid, zoals dat met de Employability Monitor wordt beoogd. Het gaat hierbij om een individuele, arbeidsorganisationele en samenlevings- c.q. overheidsvisie op employability:

- Voor een individu is employability een indicator voor de kans op betaald werk, op een aantrekkelijke arbeidspositie, nu en in de toekomst;

- Voor een werkgever is employability een indicator voor de mate waarin het intern en extern beschikbare personeelsbestand past bij de kwalificatie-eisen geldend voor functies, nu en in de nabije toekomst;

- Voor een samenleving is employability een indicator voor de mate waarin de potentiële beroepsbevolking tussen 15 en 65 jaar qua competenties en kwalificaties past bij het geheel van arbeidsplaatsen, nu en in de toekomst.

De centrale doelstelling van de Employability Monitor is het verkrijgen van inzicht in de verschillende aspecten van de ontwikkeling van de employability van de Nederlandse potentiële beroepsbevolking en de behoefte aan verdere investeringen in de employability van werkenden en niet-werkenden. De nadruk ligt dus op het derde schaalniveau, maar ook de individuele employability zal in de Employability Monitor ruime aandacht krijgen.

Bij de employability van werknemers gaat het om het vermogen en de bereidheid om werk te houden, terwijl bij niet-werkenden het vermogen en de bereidheid om werk te krijgen centraal staat. Bij de niet-werkenden kan employability dan ook primair als de 'intredekans' worden gezien. Met de in dit rapport voorgestelde opzet van de Employability Monitor wordt beoogd zowel een groot aantal uiteenlopende aspecten van de employability van werkenden en niet-werkenden in beeld te brengen, als een algemene indicatie te geven van de verschillen in de employability van verschillende groepen werkenden. Deze dubbele doelstelling wordt gerealiseerd door in de Employability Monitor een groot aantal employability-aspecten te monitoren en daarnaast een 'samenvattende' Employability Index te ontwikkelen.

Zowel het kunnen krijgen als het behouden van werk kan, zoals reeds is aangegeven, van een groot aantal factoren afhankelijk zijn. Dit maakt employability tot een 
complex begrip. In deze monitor zal geprobeerd worden alle factoren die van invloed kunnen zijn op de employability van werkenden en niet-werkenden in beeld te brengen. Hierbij moet worden beseft dat een individuele werkende of niet-werkende niet op al deze aspecten goed moet scoren om employable te zijn. Zo kunnen mensen met een opleidingsachtergrond die hen een sterke arbeidsmarktpositie geeft een zeer goede employability hebben, ook als ze niet bereid zijn om te verhuizen of op onregelmatige tijden te werken. Bovendien moeten de verschillende aspecten van de employability van individuele werkenden worden afgezet tegen de employabilitybehoeften van de sector waarin men werkzaam is. Hiermee zal in deze eerste opzet van de Employability Monitor expliciet rekening worden gehouden.

Het bovenstaande betekent dat het bij de bespreking van de diverse employabilityaspecten van werkenden en niet-werkenden niet de bedoeling is automatisch een waardeoordeel over de employability van groepen mensen te geven. Ook de in hoofdstuk zes opgenomen samenvattende Sectorale Employability Index en de Employability Index Niet-Werkenden hebben niet die intentie. Deze beide samenvattende indices hebben veel meer het doel snel inzicht te verschaffen in die aspecten van employability waarvoor in een bepaalde bedrijfssector of voor bepaalde groepen niet-werkenden mogelijk extra aandacht gewenst is.

Of de gesignaleerde oorzaken van een relatief lage 'overall' employability-score ook daadwerkelijk om maatregelen vragen is afhankelijk van prioriteiten die door belanghebbenden (bedrijfssectoren, organisaties, overheid, e.d.) worden gesteld. Blijkt bijvoorbeeld dat de employability binnen een bedrijfssector gering is als gevolg van een relatief laag opleidingsniveau, dan hangt het af van de mate waarin de kwalificatieeisen in de sector toenemen of er sprake is van een situatie die verbetering behoeft of niet. Een wat lagere score op de Sectorale Employability Index betekent dus niet automatisch dat er sprake is van een zorgelijke situatie. Het betekent wel dat verdere analyse van de oorzaken van deze relatief mindere positie wordt aangeraden.

\section{Gesprekken met sleutelfiguren}

Alvorens over te gaan tot het monitoren van employability is het echter van belang een helder beeld te schetsen van de manier waarop verschillende partijen tegen het begrip employability aankijken en hoe er tot nu toe mee wordt omgegaan. Hiertoe is een aantal gesprekken gevoerd met organisaties die betrokken zijn bij de employability-problematiek. Uit deze gesprekken bleek dat er een brede consensus bestaat over het belang van functioneringsgesprekken, opleidings- en ontwikkelingsplannen, competentiemanagement en het stimuleren van de functionele mobiliteit. Ook blijkt er bij verschillende organisaties behoefte te bestaan aan een employability-benchmark. Mede op basis van deze gesprekken zijn de conceptuele modellen opgesteld, die een houvast bieden bij het in kaart brengen van de verschillende aspecten van de employability van werknemers en niet-werkenden. Van de gevoerde gesprekken wordt een samenvatting gegeven in Appendix A. In de gesprekken is met name ook afgetast in hoeverre er bij verschillende organisaties behoefte bestaat aan een employability-benchmark. Er zijn gesprekken gevoerd met sleutelpersonen die betrokken zijn bij het personeelsbeleid in de industrie en dienstverlening. Bovendien is 
gebruik gemaakt van documentatie van onderzoek naar employability binnen de agrarische sector. Daarnaast zijn gesprekken gevoerd met vertegenwoordigers van het CNV, de werkgeversverenigingen VNO/NCW en FME/CWM (Metaal- en elektrotechnische sector) en Arbeidsvoorziening. Ten slotte is de employability-problematiek aan de orde gesteld in een gesprek met de Britse National Skills Task Force.

Uit de gesprekken komt onder andere naar voren dat employability voornamelijk maatwerk is, omdat elke individuele werknemer of niet-werkende zijn of haar eigen specifieke wensen en voorkeuren heeft ten aanzien van de loopbaan. Mede daarom vormt het jaarlijkse of halfjaarlijkse functionerings- en beoordelingsgesprek in veel organisaties de basis voor het employability-beleid. Bedrijven en sociale partners stellen zichzelf dan ook voornamelijk tot doel een kader te scheppen waarbinnen werknemers en niet-werkenden zichzelf kunnen ontwikkelen. Hoe beter dit kader, des te beter het imago als werkgever en des te meer 'high potentials' aan de organisatie kunnen worden gebonden. Behalve het functioneringsgesprek als instrument bestaat er ook grote consensus over het nut van persoonlijke en bedrijfsopleidingsplannen, het gebruik van het intranet bij de bevordering van de interne doorstroom van personeel en systemen van functieroulatie. Daarnaast wordt scherp gelet op de kwaliteit van opleidingen. Bovendien wordt met name door kleinere ondernemingen binnen de agrarische en industriële sector steeds meer aansluiting gezocht bij andere ondernemingen om gezamenlijke opleidingstrajecten op te zetten. Tevens wijzen nagenoeg alle partijen op het belang van het meten van door scholing en arbeid verworven kwalificaties en competenties en de sectoroverstijgende erkenning ervan. Hierbij wordt met name gewezen op de erkenning van de buiten formele opleidingen 'eerder verworven competenties' (EVC's).

In het gesprek met de Britse National Skills Task Force kwamen enkele centrale competenties naar voren die bepalend zijn voor het functioneren van werknemers in een bepaalde context nu en in de toekomst. Tezamen met schrijf-, lees-, spreek- en rekenvaardigheden vormen volgens het Task Force ICT-skills, probleemoplossend vermogen, teamwork en leervermogen de kerncompetenties voor een goede employability van werknemers.

Arbeidsvoorziening streeft ernaar om met behulp van een tweetal instrumenten; - de Kansmeter (een administratieve intake) en de Kwint ${ }^{3}$ (een kwalificerende intake) - in beeld te krijgen wat een werkzoekende in zijn of haar mars heeft. Aan de hand van persoonlijke kwalificaties (taal, flexibiliteit, belastbaarheid, etc.), arbeidsmarktkwalificaties (opleiding, werkervaring) en het beroepsperspectief op korte termijn wordt binnen Arbeidsvoorziening sinds 1999 in kaart gebracht welke afstand een werkzoekende heeft tot de arbeidsmarkt. Via de Kansmeter en de Kwint wordt bepaald in hoeverre een werkzoekende op een bepaald moment bemiddelbaar is. Dit wordt uitgedrukt in fases. Een fase 1 werkzoekende is direct bemiddelbaar, een fase 2 werkzoekende heeft een (re)integratietraject van korter dan één jaar nodig, een fase 3 werkzoekende heeft een (re)integratietraject van langer dan één jaar nodig. Werk-

3. Vooralsnog gaat het bij de Kwint echter om een experiment dat in enkele regio's is uitgevoerd. Een centrale dataverzameling vindt nog niet plaats. 
zoekenden in fase 4 worden (voorlopig) niet meer in staat geacht een volwaardige plaats op de arbeidsmarkt te verwerven.

\section{Opzet van het rapport}

Op basis van de gesprekken en de beschikbare literatuur op het terrein van de employability worden twee conceptuele modellen ontwikkeld die het raamwerk vormen voor de verdere inrichting van de Employability Monitor. Eén model is erop gericht de verschillende aspecten van de employability van werknemers in beeld te brengen. Het andere model is gericht op het in kaart brengen van de employability voor niet-werkenden.

\section{Werknemers}

Werknemers met een goede employability gaan gemakkelijk om met veranderingen en zijn bereid om, wanneer dat nodig is, tijdelijk andere werkzaamheden te verrichten of zich ontbrekende kennis eigen te maken. Werkgevers vragen ook om een dergelijke houding, maar zij doen dat niet in gelijke mate. Bedrijven die worden geconfronteerd met ingrijpende veranderingen moeten flexibel zijn en hebben dus meer behoefte aan een erg goede employability van hun werknemers. Het belang van employability is bovendien afhankelijk van de situatie op de arbeidsmarkt. Een krimpende werkgelegenheid betekent voor werknemers dat het belang van een goede employability groot is. De mogelijkheid bestaat immers dat elders emplooi zal moeten worden gezocht. In dit kader zijn ook de uitwijkmogelijkheden die een werknemer op de arbeidsmarkt heeft van belang. Verliezen werknemers hun baan en kunnen zij bovendien nauwelijks uitwijken naar een andere sector, dan is het risico van verlies van werk groot. Om daadwerkelijk verlies van werk te voorkomen zullen werknemers op zoek gaan naar mogelijkheden om hun employability te versterken. In eerste instantie is het de werkgever die daartoe de faciliteiten zal moeten bieden. De mate waarin bedrijven faciliteiten bieden die het verbeteren van de employability voor hun werknemers vergemakkelijken wordt echter mede bepaald door centrale afspraken van de sociale partners en het overheidsbeleid. De Nederlandse arbeidswetgeving, de door de overheid getroffen fiscale maatregelen en de afspraken in collectieve arbeidsovereenkomsten vormen in belangrijke mate het kader waarbinnen werkgevers hun employabilitybeleid kunnen voeren.

Om de employability van werknemers te monitoren is dus inzicht nodig in achtereenvolgens de bij de werknemers in de verschillende bedrijfssectoren aanwezige employability, de behoefte aan employability als gevolg van diverse ontwikkelingen, de situatie op de arbeidsmarkt en de mate waarin voorwaarden zijn geschapen om de employability van de werkenden te versterken.

\section{Niet-werkenden}

De employability van niet-werkenden kan het beste worden opgevat als de intredekans: de kans op het verkrijgen van werk. Deze intredekans is allereerst afhankelijk van de kwalificaties van de niet-werkenden. Evenals dat voor de werknemers het 
geval was hangt de waarde van deze kwalificaties echter af van de behoefte eraan op de arbeidsmarkt. Het zijn niet zozeer de ontwikkelingen binnen bedrijven die bij het bepalen van de intredekans van niet-werkenden een rol spelen als wel de ontwikkelingen op de arbeidsmarkt. Groei van de werkgelegenheid of de vervangingsvraag betekent voor niet-werkenden een grotere kans op werk en dus een grotere intredekans. Afhankelijk van de huidige intredekans van niet-werkenden bestaat er de behoefte om hun employability te verbeteren en aldus de intredekans te vergroten. In deze behoefte wordt deels voorzien door de overheid, die middels wettelijke en fiscale maatregelen de arbeidsdeelname van bepaalde groepen niet-werkenden tracht de bevorderen. Bovendien wordt door uitvoeringsinstanties en Arbeidsvoorziening een groot aantal reïntegratietrajecten aangeboden om de intrede op de arbeidsmarkt van niet-werkenden te bespoedigen.

Om de employability, ofwel de intredekans, van niet-werkenden te monitoren is dus inzicht nodig in achtereenvolgens de aanwezige employability, de situatie op de arbeidsmarkt voor specifieke groepen niet-werkenden en de mate waarin er faciliteiten worden geboden om de intredekansen van de niet-werkenden te vergroten.

Bij het in kaart brengen van de employability van werkenden en niet-werkenden zou men in de eerste plaats kunnen denken aan het in beeld brengen van de employability op individueel niveau. Dit is echter een weinig realistische invalshoek. In feite behelst dit immers een volledige registratie van de employability van de potentiële beroepsbevolking. Dit is niet alleen een zeer kostbare exercitie maar ook een exercitie die waarschijnlijk veel maatschappelijke weerstand zal oproepen. Alleen bij de geregistreerde werkzoekenden zou dit een optie kunnen zijn bij de invulling van het beleid gericht op een 'sluitende aanpak' met betrekking tot de arbeidsmarktintrede.

In deze verkennende studie zal de aandacht zich geheel richten op het in kaart brengen van de verschillende aspecten van de employability van de werkenden, verbijzonderd naar bedrijfssector en de employability van de niet-werkenden, verbijzonderd naar opleidingsniveau. Hierbij zal alleen worden gekeken naar de beschikbare informatie op geaggregeerd niveau. Wanneer in de toekomst zou worden overgegaan tot een uitgebreide cohort-studie, waarin de employability van individuele werknemers en niet-werkenden longitudinaal in kaart zou worden gebracht, zou het inzicht in de factoren die van belang zijn voor de employability van mensen kunnen worden vergroot. Hierop zal in het slothoofdstuk worden teruggekomen.

De verdere opzet van dit rapport is als volgt. In hoofdstuk 2 worden de conceptuele modellen gepresenteerd die het raamwerk vormen voor de Employability Monitor voor werkenden en niet-werkenden. In aansluiting daarop wordt in hoofdstuk 3 verslag gedaan van de verkenning van de beschikbare databronnen om de verschillende aspecten van de employability van werkenden en niet-werkenden in beeld te brengen. In dit hoofdstuk passeren verschillende databronnen de revue, waarbij wordt gezocht naar de voor het inrichten van de Monitor meest relevante databronnen. Hierbij zal worden gelet op de mate waarin databronnen gegevens bevatten 
over de gehele onderzoekspopulatie, de steekproefomvang, het aantal door de databron gemeten variabelen en de periodiciteit.

Op basis van de beschikbare databronnen wordt vervolgens in de hoofdstukken 4 en 5 een eerste invulling van de Employability Monitor voor respectievelijk de werkenden en niet-werkenden gepresenteerd. In hoofdstuk 6 worden op basis van de in hoofdstuk 4 en 5 gepresenteerde informatie twee indices ontwikkeld die een samenvattend beeld geven van zowel de employability van werkenden, als de employability van niet-werkenden: een Sectorale Employability Index voor werknemers en een Employability Index voor niet-werkenden. In hoofdstuk 7 wordt ten slotte aangegeven welke lacunes zich voordoen in de beschikbare informatie, waardoor een optimale invulling van de Employability Monitor vooralsnog niet mogelijk is. In aansluiting daarop wordt een voorstel gedaan voor de verdere ontwikkeling van de Employability Monitor. 


\section{Het raamwerk voor de opzet van de Employability Monitor}

In dit hoofdstuk worden twee conceptuele modellen gepresenteerd die het mogelijk maken de verschillende aspecten die van belang zijn voor de employability van werknemers en niet-werkenden op systematische en consistente wijze in kaart te brengen. De modellen die in dit hoofdstuk worden gepresenteerd en onderbouwd vormen een raamwerk voor de opzet van de uiteindelijke Employability monitor.

\subsection{Employability model voor werknemers}

\subsubsection{Conceptueel model}

Employability van werknemers kan nader worden gedefinieerd als het vermogen en de bereidheid van mensen om werk te houden. Omdat een goede Employability Monitor vereist dat aandacht wordt besteed aan een zo breed mogelijk scala van relevante factoren is voor de duidelijkheid het model in een aantal dimensies onderverdeeld. Deze dimensie-indeling is afgeleid van de fase-indeling zoals die is gebruikt voor de Sectorale Employability Index (De Grip, Van Loo en Sanders, 1998). Allereerst wordt gekeken naar de individuele employability van werknemers, die werkzaam zijn binnen verschillende bedrijfssectoren. Vervolgens wordt gekeken naar de behoefte aan employability die op grond van diverse maatschappelijke ontwikkelingen binnen verschillende sectoren bestaat. Om een beeld te krijgen van de mogelijkheden die groepen werknemers hebben om aan de slag te blijven wordt vervolgens gekeken naar de arbeidsmarktontwikkelingen, die voor bepaalde groepen werknemers van belang zijn. Hierbij wordt gekeken naar arbeidsmarktperspectief en naar uitwijkmogelijkheden. Ten slotte wordt gekeken naar de bestaande effectueringcondities. Hierbij komt de rol van de werkgever aan bod als facilitator en wordt de vraag gesteld in hoeverre het institutionele kader faciliterend is voor de employability van de werknemers in de desbetreffende sector. Bij het in beeld brengen van de employability van werknemers is de bedrijfssector waarin men werkzaam is telkens de primaire invalshoek. Hiervoor is gekozen, omdat dit met name voor de effectueringscondities en de employability-behoefte de meest voor de hand liggende en praktisch haalbare invalshoek is. Het belangrijkste nadeel van een dergelijke benadering is dat geen inzicht wordt verkregen in de mate waarin de employability van werkenden binnen een bepaalde sector uiteenloopt. Met het aggregeren van individuele gegevens naar bedrijfssector wordt immers voorbijgegaan aan individuele verschillen. Hierdoor kan ook niet worden aangegeven hoe de employability van mensen zich op individueel niveau ontwikkelt. Verderop in deze rapportage worden om deze reden de mogelijkheden van een cohort-studie nader bekeken.

De situatie voor wat betreft de employability van werknemers in een bepaalde bedrijfssector kan op basis van het model vrij gemakkelijk worden bepaald. 
Figuur 2.1

Employability Monitor: model voor werknemers

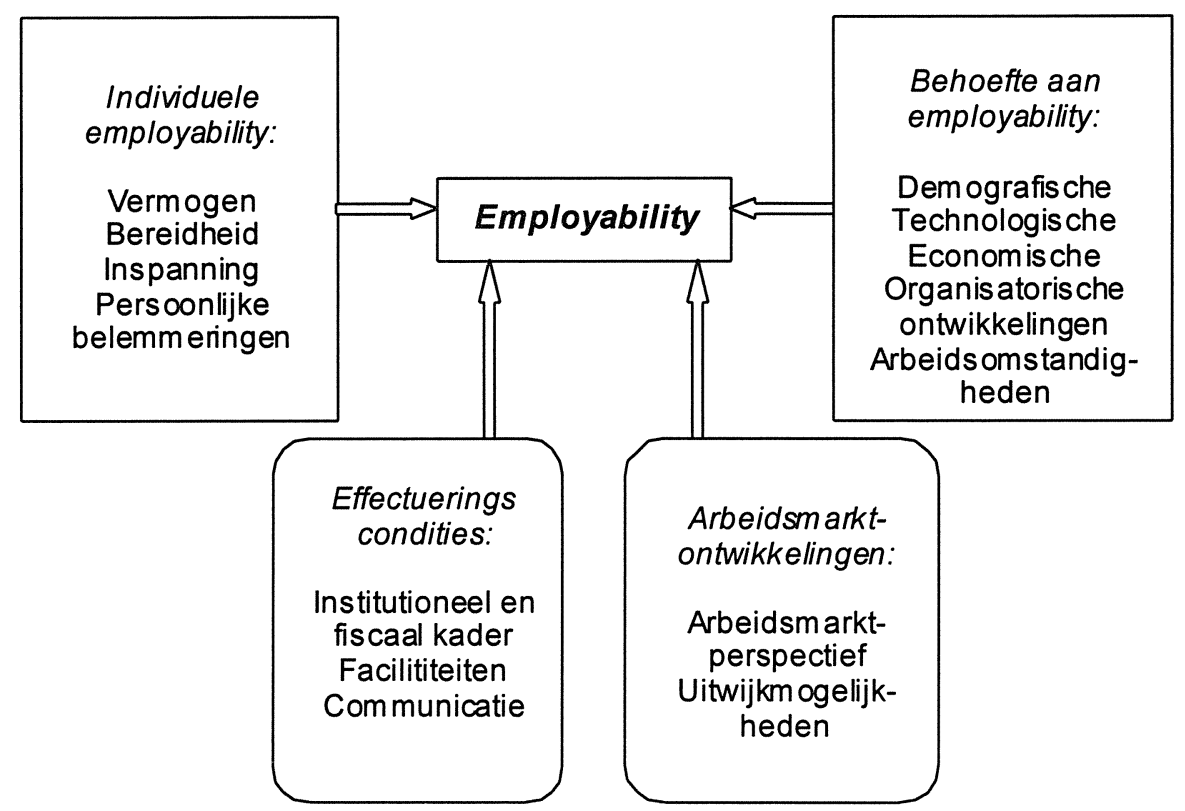

Allereerst wordt op basis van individuele vermogens, bereidheid, inspanningen en belemmeringen een beeld verkregen van de individuele employability van werknemers per bedrijfssector. Vervolgens wordt op basis van de mate waarin bedrijfssectoren worden gekenmerkt door vergrijzing, technologische vernieuwing, organisatorische veranderingen, gevoeligheid voor economische ontwikkelingen en belastende arbeidsomstandigheden bepaald wat de behoefte van bedrijfssectoren is aan werknemers met een goede employability. Door de individuele employability van werknemers in een bedrijfssector te vergelijken met de mate waarin in dezelfde bedrijfssector behoefte bestaat aan werknemers met een goede employability kan vervolgens een beeld worden verkregen van relatieve tekorten aan employability. Door vervolgens te kijken naar de arbeidsmarktontwikkelingen voor de betreffende sectoren kan in beeld worden gebracht in hoeverre een krimpende werkgelegenheid de gevaren van een tekort aan employability versterkt. Wanneer de employability relatief gering is en er bovendien sprake is van een teruglopende vraag naar arbeid lopen werknemers het risico dat zij én hun huidige baan verliezen én nergens anders aan de slag kunnen binnen de bedrijfssector waar men nu werkzaam is. Op basis van de uitwijkmogelijkheden kan dan nog worden bezien in hoeverre een werknemer in dat geval kan uitwijken naar andere bedrijfssectoren, waar sprake is van een groei van de werkgelegenheid. 
Afhankelijk van de mate waarin een tekort aan employability zich voordoet in combinatie met een krimpende werkgelegenheid is de behoefte aan beleid gericht op het vergroten van de employability van werknemers in een bepaalde sector vanuit de optiek van de werknemer groter en dus rijst de vraag of in de betreffende sector voldoende aandacht wordt besteed aan employability. Om dit goed in beeld te krijgen wordt ten slotte gekeken naar de effectueringscondities die binnen de verschillende bedrijfssectoren bestaan. Op basis van de inventarisatie van bestaande institutionele en fiscale kaders en door organisaties geboden faciliteiten ter bevordering van de employability is het mogelijk uiteindelijk te bepalen in hoeverre er binnen een bedrijfssector voorwaarden zijn geschapen om de employability van werknemers te bevorderen.

Door op de hier beschreven manier de employability van werknemers te monitoren is goed zichtbaar te maken op welke beleidsterreinen er een verantwoordelijkheid ligt voor de overheid om via aanpassingen van het bestaande institutionele en fiscale kader werkgevers en werknemers te stimuleren voortdurend te werken aan employability. Bovendien wordt duidelijk in hoeverre werkgevers gebruik maken van de ruimte die hen wordt geboden om te investeren in de employability van werknemers.

\subsubsection{Individuele employability van werknemers}

De individuele employability van werknemers kan het beste worden bepaald aan de hand van een viertal centrale vragen, te weten:

- Wat kan de werknemer (vermogen)?

- Wat wil de werknemer (bereidheid)?

- Wat doet de werknemer feitelijk (inspanning)?

- Zijn er persoonlijke belemmeringen die het werken aan employability voor de werknemer bemoeilijken (persoonlijke belemmeringen)?

Werknemers zijn bijvoorbeeld beter employable wanneer:

- zij over breed inzetbare kwalificaties beschikken;

- zij deze kwalificaties ook in brede zin willen aanwenden;

- zij hiertoe de nodige actie ondernemen;

- zij daarbij niet of zo min mogelijk worden belemmerd door persoonlijke omstandigheden.

\section{Wat kan de werknemer?}

Inzicht in wat een werknemer kan staat vanzelfsprekend aan de basis van het bepalen van de kans op het behoud van werk. Om een beeld te kunnen krijgen van de vermogens van werknemers wordt alleen gekeken naar het employability-vermogen dat een werknemer op dit moment heeft.

Dit vermogen kan worden bepaald door allereerst te kijken naar iemands initiële en vervolgopleiding. Opleidingsniveau en opleidingsrichting bepalen immers de diversiteit aan functies of werkzaamheden die een werknemer in potentie zou kunnen 
vervullen. Daarnaast is het van belang te kijken naar de competenties ${ }^{4}$ die werknemers hebben verworven. Naast scholing en competenties zorgt ook werkervaring voor de opbouw van het employability-vermogen. Werkervaring is daarbij niet alleen van belang voor de ontwikkeling van vakspecifieke vaardigheden, maar kan bijvoorbeeld ook zorgen voor het ontwikkelen van communicatieve en leidinggevende vaardigheden, een groter probleemoplossend vermogen en het leren werken in teamverband.

Opleiding, competenties en werkervaring en de daarmee verkregen kwalificaties vormen de basis voor een aantal vermogens die specifiek van belang zijn bij het in beeld brengen van de individuele employability van werknemers. Hierbij gaat het om het:

- mobiliteitsvermogen;

- opleidingsvermogen;

- vermogen tot een brede inzet.

Mobiliteitsvermogen is het vermogen van werknemers om op een andere dan de huidige locatie of in een andere dan de huidige functie te gaan werken. Het mobiliteitsvermogen van een werknemer hangt vooral af van de aanwezige kwalificaties. Opleiding, competenties en werkervaring vormen dus de basis. Omdat productiviteit een belangrijke bepaler is voor de mogelijkheden van werknemers om van functie te veranderen - een hoge productiviteit vergroot de mobiliteitsmogelijkheden (De Graaf en Luijkx, 1997) - en bovendien is aangetoond dat de productiviteit toeneemt naarmate een werknemer meer ervaring heeft en hoger is opgeleid (zie o.a. Becker, 1964), kan ervan uitgegaan worden dat het mobiliteitsvermogen toeneemt naarmate iemand meer opleiding heeft gevolgd en meer werkervaring heeft opgedaan. Het is echter wel van belang ook te kijken naar het soort opleiding(en) dat iemand gevolgd heeft en de breedte c.q. eenzijdigheid van de werkervaring. Thijssen (1989) duidt erop dat een geconcentreerde ervaringsopbouw ertoe kan leiden dat een werknemer vast komt te zitten in de huidige functie. Het aantal jaren dat een werknemer in één en dezelfde functie bij één en dezelfde werkgever op één en dezelfde locatie verblijft, indiceert iemands ervaringsconcentratie.

Opleiding en werkervaring zouden allebei apart moeten worden beschouwd om een beeld te krijgen van de kwalificaties van werknemers. Mede daarom ligt het voor de hand om het risico van ervaringsconcentratie als uitgangspunt te nemen bij het bepalen van het mobiliteitsvermogen. Is een werknemer hoger opgeleid, heeft hij een bredere werkervaring en verblijft hij relatief kort in de huidige functie bij de huidige werkgever dan bevordert dit de individuele employability. Het mobiliteitsvermogen van werknemers wordt derhalve bepaald aan de hand van de mate van ervaringsconcentratie.

4. Onder competenties worden in eerste instantie de lees-, schrijf-, spreek- en rekenvaardigheid verstaan. Samen met vakinhoudelijke en beroepsspecifieke vaardigheden vormen deze competenties de kwalificaties van werknemers.

10 
Opleidingsvermogen is het vermogen van werknemers om verder te leren. Het opleidingsvermogen van werknemers is bepalend voor de mate waarin werknemers in staat zijn om te worden bij- of omgeschoold. Er wordt derhalve in dit kader ook wel gesproken over de schoolbaarheid van werknemers. Om het opleidingsvermogen van een werknemer te meten is het aantal jaren scholing de meest voor de hand liggende indicator. Hierbij dient het echter wel te gaan om afgeronde opleidingen, omdat afgebroken opleidingen, waarvan niet bekend is waarom deze zijn afgebroken, weinig zeggen over het niveau waarop een werknemer opereert. Daarbij zou ook rekening moeten worden gehouden met de tijd die iemand nodig had om een bepaalde opleiding met succes af te ronden. Afhankelijk van de discrepantie tussen nominale en feitelijke duur van een door een werknemer afgeronde opleiding, zegt dit iets over het vermogen van werknemers om te leren. Immers hoe sneller een werknemer een opleiding afrondt hoe meer leervermogen de desbetreffende werknemer heeft, al zou daarbij idealiter ook rekening moeten worden gehouden met een eventuele externe oorzaak van de langere studieduur (bijvoorbeeld langdurige ziekte). Kanttekening bij een dergelijke meetmethode is dat per individu in principe voor de gehele studieduur zou moeten worden bepaald hoe de tijd is doorgebracht. De feitelijke studieduur kan immers van de nominale studieduur verschillen door ziekte, maar ook door extra-curriculaire activiteiten, bijbaantjes, het 'jaar-er-uit' of bijvoorbeeld veranderen van studie. Dergelijke oorzaken van een langere studieduur zijn nauwelijks meetbaar en zouden voor een grote ruis zorgen in de onderzoeksresultaten. Vooralsnog is voor opleidingsvermogen nog geen valide en betrouwbare indicator voorhanden.

Het vermogen tot brede inzet is het vermogen dat een werknemer heeft om buiten het eigen functiegebied bepaalde taken te verrichten. Een brede inzetbaarheid geeft werknemers een breed palet van vaardigheden, waardoor zij op meerdere plaatsen binnen de organisatie of daarbuiten gemakkelijker aan de slag kunnen. Het vermogen om breed te worden ingezet wordt opgebouwd door een brede opleidingsachtergrond en een brede werkervaring. Een brede inzet in het verleden is waarschijnlijk de beste voorspeller voor een brede inzet in de toekomst. Heeft een werknemer zich in het (recente) verleden dus breed ingezet dan zal zijn vermogen tot brede inzet groot zijn.

\section{Wat wil de werknemer?}

Naast een helder beeld van het employability-vermogen van werknemers is het ook van belang een beeld te hebben van de wensen van werknemers met betrekking tot hun loopbaan. Een werknemer kan immers nog zoveel functies kunnen vervullen, wanneer de wil er niet is om ze te gaan vervullen is de feitelijke inzetbaarheid van de werknemer gering. Om te bepalen waartoe een werknemer bereid is, kan het best direct worden gevraagd naar de bereidheid die werknemers hebben met betrekking tot de drie centrale employability-aspecten: mobiliteit, opleiding en inzetbaarheid. 
Hierbij zijn de volgende aandachtspunten van belang:
Mobiliteit: $\quad$ - de bereidheid om van functie te veranderen (Functionele mobili- teit);
- de bereidheid om op verschillende fysieke werklocaties actief te zijn (Geografische mobiliteit).
Opleiding: _ - de bereidheid om opleidingen en cursussen te volgen (Oplei- dingsbereidheid).
Inzetbaarheid: - de bereidheid om verschillende taken en functies te vervullen (Kwalitatieve inzetbaarheid);
- de bereidheid om extra werkzaamheden (overuren) te verrich- ten (Kwantitatieve inzetbaarheid).

Om deze verschillende vormen van bereidheid in beeld te krijgen moet worden gekeken naar de intenties van werknemers.

Functionele mobiliteitsbereidheid is een belangrijke indicator voor iemands individuele employability. Bij functionele mobiliteitsbereidheid gaat het om de bereidheid van werknemers om een andere functie te aanvaarden. Hierbij kan het ook gaan om een functie bij een ander onderdeel van de organisatie of een functie bij een andere organisatie. De mate waarin een werknemer bereid is van functie te veranderen kan bepalend zijn voor de mate waarin kwalificaties van een werknemer mogelijk zullen worden benut.

Geografische mobiliteitsbereidheid heeft betrekking op de bereidheid van werknemers om te verhuizen voor een andere functie. Hierbij kan het overigens ook gaan om het aanvaarden van een functie die min of meer gelijk is aan de huidige. Het gaat erom dat een werknemer aangeeft bereid te zijn op een andere locatie te gaan werken en daarvoor eventueel ook te willen verhuizen. Naarmate een werknemer minder gebonden is aan de huidige woon- c.q. werkomgeving, kan hij/zij zich gemakkelijker over de arbeidsmarkt verplaatsen.

Bij opleidingsbereidheid gaat het om de bereidheid van werknemers tot het volgen van scholing, opleidingen en cursussen. Is een werknemer bijvoorbeeld niet bereid aanvullende scholing te volgen dan zijn de mogelijkheden om door te groeien meestal gering. Bovendien is scholing tegenwoordig van dusdanig groot belang dat het niet volgen van opleidingen, hetzij vakspecifiek, hetzij meer generalistisch, er onherroepelijk toe zal leiden dat aanwezige kennis snel veroudert, waardoor de waarde van het menselijk kapitaal waarover iemand beschikt snel afneemt. De individuele employability van werknemers is er dus bij gebaat dat werknemers bereid zijn zich te laten (bij)scholen.

Bereidheid ten aanzien van de kwalitatieve inzetbaarheid heeft betrekking op de mate waarin een werknemer bereid is zich in te zetten op taakgebieden die niet tot de eigen functie behoren. Wanneer een werknemer aangeeft in principe bereid te zijn zich in te zetten op andere gebieden dan die van de eigen functie, is dat voor de werkgever een signaal dat betreffende werknemer zich breed wil ontwikkelen. 
Naast de kwalitatieve inzetbereidheid is ook de bereidheid tot een brede kwantitatieve inzet van werknemers van belang bij het in beeld brengen van de individuele employability. Kwantitatieve inzetbaarheid heeft betrekking op de mate waarin iemand bereid is extra uren te werken of met uren te schuiven. De mate dus waarin iemand flexibel is wat betreft de werktijden. Is een werknemer in principe bereid zo nu en dan eens wat extra's te doen dan maakt dat de werknemer vanzelfsprekend aantrekkelijker voor werkgevers wat hun positie op de arbeidsmarkt versterkt. Dit verbetert natuurlijk iemands employability. Kanttekening hierbij is wel dat het in principe niet zou moeten gaan om overuren die gemaakt zijn omdat iemand werk niet afkrijgt binnen de tijd waarin anderen dat wel kunnen.

\section{Wat doet de werknemer feitelijk?}

Natuurlijk is het van groot belang dat werknemers, die een bepaald vermogen hebben en een bepaalde bereidheid, ook de nodige acties ondernemen om de waarde op de arbeidsmarkt zoveel mogelijk intact te houden. Hoe vaak leiden intenties immers uiteindelijk tot inspanningen? Om deze reden is het belangrijk om ook inzicht te krijgen in de inspanningen die werknemers leveren om hun employability op peil te houden. Opnieuw zal hierbij moeten worden gekeken naar de drie aspecten van employability: mobiliteit, opleiding en inzetbaarheid.

Mobiliteit: $\quad$ - inspanningen om van functie te veranderen (Functionele mobiliteit);

- inspanningen om op verschillende fysieke werklocaties actief te zijn (Geografische mobiliteit).

Opleiding: - scholingsinspanningen van de werknemer.

Inzetbaarheid: - mate waarin een werknemer verschillende taken en functies vervult (Kwalitatieve inzetbaarheid);

- mate waarin een werknemer zich flexibel opstelt qua werktijden (Kwantitatieve inzetbaarheid).

Om een eenduidig beeld te kunnen schetsen van de inspanningen die werknemers leveren met betrekking tot hun functionele mobiliteit kan het beste worden gekeken naar het huidige sollicitatiegedrag van werknemers. Het is hierbij overigens wel van belang enige nuances aan te brengen waar het gaat om gedwongen mobiliteit doordat bijvoorbeeld een functie of afdeling wordt opgeheven. Is dit namelijk het geval dan zit er voor werknemers weinig anders op dan van functie te veranderen.

Ook inspanningen op het gebied van de geografische mobiliteit kunnen in beeld worden gebracht door naar het sollicitatiegedrag van werknemers te kijken. Naarmate werknemers meer solliciteren op vacatures waarvan de standplaats op enige afstand ligt van de huidige werkplek geven zij meer uiting aan hun geografische mobiliteit.

De inspanningen op het gebied van opleiding zijn eveneens van belang bij het in beeld brengen van de individuele employability van werknemers. Om de opleidingsinspanningen in beeld te brengen zal gekeken moeten worden naar wat werknemers 
op het moment aan scholing en opleiding doen gericht op de functie die zij op korte termijn hopen te bekleden. Dit kan overigens ook de huidige functie zijn. In dat geval zal het gaan om opleidingen die erop gericht zijn bij te blijven op het huidige vakgebied door op de hoogte te zijn van de nieuwste ontwikkelingen. Ook opleidingen die gevolgd worden omdat grote veranderingen voor de huidige functie op stapel staan zijn van belang.

Behalve inspanningen om in een andere dan de huidige functie aan de slag te komen, zijn ook de inspanningen op het gebied van de kwalitatieve inzetbaarheid van belang bij het bepalen van de individuele employability van werkenden. Het gaat hierbij om de mate waarin werknemers zich inzetten op andere gebieden dan die van de eigen functie. Dergelijke inspanningen maken de werknemer breder inzetbaar en dus beter employable. Vanzelfsprekend speelt hierbij ook het terrein waarop een werknemer zich breed inzet een rol, omdat nu eenmaal niet iedere opgedane vaardigheid even breed toepasbaar is. Het overnemen van taken van anderen heeft dus zeker geen eenduidige impact. Zeker is echter wel dat het regelmatig uitvoeren van andere taken en functie-onderdelen bijdraagt tot een bredere inzetbaarheid.

Ten slotte zijn de inspanningen op het gebied van de kwantitatieve inzetbaarheid van belang. Hierbij gaat het met name om activiteiten van werknemers die erop duiden dat de werknemer, indien nodig, extra uren of op wisselende tijden werkt. Naarmate werknemers op dit gebied meer inspanningen verrichten geven zij aan qua werktijden breed inzetbaar te zijn.

\section{Wat voor persoonlijke belemmeringen staan de werknemer in de weg?}

Ondanks dat werknemers misschien wel het vermogen en de bereidheid hebben en bovendien de inspanningen leveren om optimaal te blijven functioneren op de arbeidsmarkt heeft toch niet elke werknemer in dezelfde mate de mogelijkheden om de eigen employability te beïnvloeden. De ene werknemer heeft immers geheel andere omstandigheden om rekening mee te houden dan de andere. Behalve het vermogen, de bereidheid en de inspanningen van werknemers om op de arbeidsmarkt actief te blijven moet ook aandacht worden besteed aan de persoonlijke belemmeringen die iemands individuele employability verminderen. Belemmeringen die hierbij op het eerste gezicht invloed zouden kunnen hebben zijn bijvoorbeeld de gezinssituatie, de leeftijd of het hebben van bepaalde arbeidshandicaps.

De gezinssituatie is in bijna alle gevallen mede bepalend voor de mate waarin een werknemer inspanningen levert ten behoeve van de eigen employability. Het hebben van jonge kinderen kan bijvoorbeeld al tot gevolg hebben dat werknemers nauwelijks in staat zijn cursussen te volgen, omdat het hen aan tijd ontbreekt. Het hebben van schoolgaande kinderen of een werkende partner maakt dat werknemers minder geneigd zullen zijn te verhuizen over grotere afstanden. Er zijn immers meerdere belangen in het spel.

Leeftijd kan op meerdere manieren een belemmerende werking hebben. Allereerst bestaat er een aantal beroepen en functies waar leeftijd een belangrijk criterium 
vormt bij de selectie. Ook het feit dat, gezien de terugverdientijd van de investering, werkgevers minder in de opleiding van oudere werknemers investeren dan in de opleiding van jongere werknemers maakt leeftijd tot een belangrijke belemmering bij het werken aan de individuele employability. Ten slotte is het voor oudere werknemers die dreigen hun baan te verliezen veel moeilijker om een nieuwe baan te vinden en dus actief te blijven op de arbeidsmarkt. Leeftijd kan dus eveneens een belangrijke persoonlijke belemmering vormen voor het behoud van werk.

Inzicht in de belemmeringen die voor werknemers bestaan bij het werken aan de eigen employability zal een aantal zaken verhelderen die van groot belang zijn bij het maken van beleid. Voordat cursussen worden aangeboden kan bijvoorbeeld worden gekeken of het niet verstandiger is eerst een aantal belemmeringen weg te nemen. Het aanpassen van de werkplek of het zorgen voor kinderopvang kan voor veel werknemers net dat steuntje in de rug zijn dat zij nodig hebben om te besluiten een opleiding te gaan volgen, eens wat taken van anderen over te nemen of te veranderen van functie.

\subsubsection{Behoefte aan employability}

De behoefte aan employability die binnen de verschillende bedrijfssectoren bestaat wordt bepaald aan de hand van de intensiteit waarmee maatschappelijke ontwikkelingen een rol spelen voor de organisaties in de desbetreffende sector. Afhankelijk van de sector waarbinnen een organisatie opereert kan worden bepaald in hoeverre er behoefte bestaat aan werknemers die employable zijn. Een vijftal zaken is hierbij van belang (zie ook: De Grip, Van Loo en Sanders, 1998):

- demografische ontwikkelingen;

- economische ontwikkelingen;

- technologische ontwikkelingen;

- organisatorische ontwikkelingen;

- arbeidsomstandigheden.

Naarmate ontwikkelingen op de vier eerstgenoemde gebieden voor een bepaalde sector een grotere rol spelen, neemt de behoefte aan employability binnen een bedrijfssector toe. Snelle ontwikkelingen vragen immers om een slagvaardige groep werknemers, omdat kwalificaties sneller verouderen en functies sneller van inhoud veranderen. Bovendien maken belastende arbeidsomstandigheden werknemers extra kwetsbaar in hun functie. Binnen organisaties bestaat, afhankelijk van de intensiteit van de ontwikkelingen en de mate van fysieke c.q. psychische belasting, een bepaalde behoefte aan personeel dat zich gemakkelijk en snel aan veranderingen kan aanpassen. Aan beleid dat gericht is op het bevorderen van de employability van werknemers bestaat dus de grootste behoefte in die organisaties waar de ontwikkelingen in de context het snelst gaan en de arbeidsomstandigheden het meest belastend zijn. 


\section{Demografische ontwikkelingen}

De ontgroening en vergrijzing van de beroepsbevolking vergroten het maatschappelijke belang van de employability van oudere werknemers. Scenario-analyses van het CPB maken duidelijk dat het aandeel van de 55+-ers in de beroepsbevolking in de periode 1995-2020 verdubbelt of zelfs verdrievoudigt. Bovendien zal de groep 40-54jarigen in omvang aanzienlijk toenemen, terwijl de groep jongere werknemers zowel in relatieve als in absolute zin steeds kleiner wordt. De vergrijzing en ontgroening stellen organisaties voor een aantal problemen. Allereerst worden steeds meer van de in de afgelopen decennia in omvang toegenomen uittredingswegen (o.a. VUT) voor oudere werknemers te duur. Bovendien is het vroegtijdig laten afvloeien van oudere werknemers steeds minder interessant voor werkgevers aangezien zij niet langer kunnen putten uit een ruim aanbod van jonge mensen die klaar staan om de plek van de oudere werknemers over te nemen. De arbeidsmarktkrapte, die mede het gevolg is van deze demografische ontwikkelingen maakt het voor werkgevers erg belangrijk om oudere werknemers aan de slag te houden en jongere werknemers breed inzetbaar.

In die sectoren waar de vergrijzing en ontgroening van de werknemers zich het sterkst voordoen, zal de meeste aandacht moeten worden besteed aan employability. De behoefte aan werknemers die employable zijn is in die sectoren dan ook relatief groot.

\section{Economische ontwikkelingen}

Economische ontwikkelingen kunnen de aanleiding zijn voor ingrijpende veranderingen binnen de organisatie. Met name de concurrentie, zowel nationaal als internationaal, speelt hierbij een rol. Analyse van de (internationale) concurrentiepositie van bedrijven heeft duidelijk gemaakt dat het beschikbare human capital een steeds prominentere rol gaat spelen (Porter, 1990). Veranderingen in de manier van concurreren vragen in dit geval om extra aandacht voor kennis en vaardigheden van werknemers. De behoefte aan werknemers met een goede employability neemt daarmee toe, omdat concurrentie op kennis en knowhow vraagt om werknemers die in staat zijn zich snel aan te passen en zich snel nieuwe kennis en vaardigheden eigen te maken.

Behalve de manier van concurreren is ook de mate van concurrentie van belang. Opereert een organisatie in een vrije markt met veel concurrenten, dan wordt van werknemers een grote slagvaardigheid geëist, omdat snel moet worden ingespeeld op veranderingen in de context. Naarmate de concurrentie sterker is, is de behoefte aan employability dus groter. Ook is er bij bedrijven die te maken hebben met een sterke concurrentie over het algemeen wat minder ruimte voor investeringen in het human capital, waardoor de behoefte aan werknemers die zo snel mogelijk en zo goedkoop mogelijk nieuwe kennis en vaardigheden aanleren alleen maar toeneemt. De behoefte aan werknemers die employable zijn is in die organisaties dus groot. 


\section{Technologische ontwikkelingen}

Technologische ontwikkelingen spelen eveneens een belangrijke rol bij het in beeld brengen van de behoefte aan employability. Met name ontwikkelingen die plaatsvinden op het gebied van de informatie en communicatietechnologie (ICT) en de automatisering hebben belangrijke consequenties voor de kwalificatieveroudering van de werkenden in verschillende bedrijfssectoren. ICT-ontwikkelingen en automatisering hebben grote invloed op de manier waarop binnen organisaties wordt gewerkt. De introductie van geld-, stortings-, en wisselautomaten in de banksector heeft er bijvoorbeeld toe geleid dat kassiersfuncties ingrijpend zijn veranderd (Stroeken, 1993), om niet te spreken van de invloed van de introductie van computers, mobiele telefonie et cetera. Automatisering heeft echter niet alleen geleid tot het verdwijnen van een groot aantal functies en de sterke groei van een aantal andere functies. Het heeft er ook toe geleid dat werkzaamheden steeds sneller veranderen, waardoor veel werknemers worden geconfronteerd met een zekere mate van functiespecifieke kwalificatieveroudering. Dat wil zeggen dat de aanwezige kennis en vaardigheden niet meer toereikend zijn voor een adequate functievervulling. Werknemers en organisaties dienen continu aandacht te hebben voor manieren om kennis en vaardigheden up-to-date te houden. De technologische vernieuwingen die de behoefte aan employability het meest beïnvloeden zijn de mate van automatisering en de mate van informatisering.

\section{Organisatorische ontwikkelingen}

Doordat de omgeving van organisaties voortdurend aan verandering onderhevig is moet een organisatie zich een grote mate van flexibiliteit aanmeten om op een gepaste manier te kunnen reageren en anticiperen op deze veranderingen. Anticiperen en reageren doen organisaties door intern voortdurend veranderingen door te voeren. Deze veranderingen en ontwikkelingen zijn overigens in de meeste gevallen gerelateerd aan andere ontwikkelingen die in deze paragraaf zijn besproken. Technologische vernieuwingen bijvoorbeeld vragen vaak om ingrijpende wijzigingen van het productieproces en economische ontwikkelingen kunnen ertoe leiden dat bepaalde bedrijfsonderdelen worden afgestoten of opgedoekt. Met name organisatorische veranderingen die van invloed zijn op de personeelssamenstelling spelen een belangrijke rol bij het bepalen van de employability-behoefte. Fusies, reorganisaties en veranderingen in het productieproces zijn de meest sprekende voorbeelden. Bij dergelijke veranderingen is nagenoeg altijd sprake van een zekere verandering in de functie en de werkzaamheden van de werknemers. Reorganisaties kunnen er bijvoorbeeld toe leiden dat bepaalde functies geheel of gedeeltelijk komen te vervallen. In dat geval ontstaat er een behoefte aan employability van werknemers om ervoor te zorgen dat zij elders in de organisatie in een andere functie verder kunnen (zie ook: Borghans, c.s. 2000).

\section{Belastende arbeidsomstandigheden}

Ten slotte is het van belang een goed beeld te krijgen van de mate waarin de arbeidsomstandigheden van werknemers belastend zijn. Hierbij spelen zowel de fy- 
sieke als psychische belasting een rol. Fysieke belasting heeft betrekking op bijvoorbeeld zwaar tillen, werken met trillende apparaten, of werken in lawaaierige omstandigheden. Is er sprake van een hoge fysieke belasting dan wordt een werknemer waarschijnlijk eerder geconfronteerd met problemen bij het uitoefenen van diens functie. Deze problemen kunnen ertoe leiden dat een werknemer in een andere soort functie emplooi moet zoeken. Wanneer deze situatie zich voordoet, zal een beroep gedaan worden op de employability van de werknemer.

Psychische belasting heeft betrekking op die factoren die de werknemer mentaal belasten, bijvoorbeeld een hoge werkdruk, eentonig werk of een slechte sfeer op de werkplek. Ook deze factoren kunnen ertoe leiden dat werknemers op den duur hun huidige functie niet meer aan kunnen, als gevolg van burn-out of stressverschijnselen. Ook in dat geval zal een beroep gedaan worden op de employability van werknemers om vroegtijdige arbeidsmarktuitstroom te voorkomen.

De mate waarin arbeidsomstandigheden belastend zijn, bepaalt dus voor een belangrijk deel de mate waarin op bepaalde arbeidsmarktsegmenten behoefte bestaat aan een goede employability van werknemers (zie ook: ROA, 2000). Belastende arbeidsomstandigheden kunnen er immers toe leiden dat werknemers hun functie niet meer optimaal kunnen invullen. Zij zullen in dat geval uit moeten gaan zien naar een andere functie, waarbij hun employability een belangrijke rol speelt, zeker ook voor de organisatie waarbinnen zij actief zijn. Het is immers voor een organisatie ook aantrekkelijker werknemers te herplaatsen dan ze te laten uitstromen naar de WAO.

\subsubsection{Arbeidsmarktperspectieven}

De ontwikkelingen die aan de basis staan van de behoefte aan employability die binnen sectoren bestaat bepalen voor een deel ook de arbeidsmarktperspectieven van de werknemers in de verschillende bedrijfssectoren. Immers, de genoemde maatschappelijke ontwikkelingen zijn er in veel gevallen verantwoordelijk voor dat functies van inhoud veranderen, dat andere kwalificaties gevraagd worden en dat bepaalde functies zelfs geheel verdwijnen en er geheel nieuwe functies ontstaan.

De op middellange termijn te verwachten arbeidsmarktperspectieven geven een indicatie van de mate waarin werknemers erop kunnen vertrouwen dat de werkgelegenheid in het beroep, waarin zij nu actief zijn, stabiel zal blijven of zelfs zal groeien, of dat de werkgelegenheid in het beroep dat men uitoefent sterk zal afnemen. Daarbij is het van belang om ook te kijken naar eventuele sectorale verschillen (zie ook: ROA, 2000). Bovendien is het van belang of de opleidingsachtergrond die iemand heeft over enige jaren nog toereikend zal zijn voor een adequate uitoefening van het beroep dat men nu heeft. Dit maakt het eveneens interessant om te kijken naar de upgradingstendensen in de verschillende beroepsgroepen (zie ook: ROA, 1999). De arbeidsmarktperspectieven voor mensen met een bepaalde opleidingsachtergrond worden bepaald door een vergelijking te maken van vraag naar en aanbod van werknemers met de desbetreffende opleiding. 
Op basis van prognoses kan ook een idee worden verkregen van mogelijke alternatieven en ontwikkelingswegen die voor werknemers met specifieke achtergronden openstaan. Dit door te kijken naar de uitwijkmogelijkheden. De uitwijkmogelijkheden geven een beeld van de mate waarin arbeidskrachten met een bepaalde opleidingsachtergrond zouden kunnen uitwijken naar andere beroepsgroepen op een aansluitend of hoger functieniveau en/of kunnen uitwijken naar andere bedrijfssectoren. De uitwijkmogelijkheden kunnen worden bepaald aan de hand van een spreidingsindex, die een indicatie geeft van het aantal beroepsgroepen of bedrijfssectoren waarnaar men kan uitwijken (zie ook: ROA, 1999). Op basis van de uitwijkmogelijkheden zou bijvoorbeeld zichtbaar kunnen worden gemaakt wat de mogelijkheden zijn van bankwerkers in de metaalsector om uit te wijken naar een andere sector of een andere beroepsgroep.

\subsubsection{Effectueringscondities}

De confrontatie van de bij de werknemers in een sector aanwezige individuele employability met de behoefte aan employability in de desbetreffende sector levert een indicatie op van terreinen waar mogelijk extra inspanningen noodzakelijk zijn, hetzij door bepaalde faciliteiten te bieden, hetzij door bepaalde belemmeringen weg te nemen. In dit kader is het van belang een beeld te krijgen van de inspanningen die werkgevers leveren om de employability van de werknemers te effectueren. We spreken in dit verband van de effectueringscondities. Hierbij gaat het om mogelijkheden die werkgevers bieden aan werknemers om hun employability tot hun recht te laten komen c.q. versterken. Hierbij is het ook van belang oog te hebben voor de sectorale institutionele kaders waarbinnen werkgevers opereren. Bij bedrijfs-CAO's voor grote ondernemingen overlapt dit vanzelfsprekend met de door het bedrijf geboden faciliteiten.

Drie hoofdaspecten zijn hierbij van belang:

- Institutionele en fiscale kaders:

Centrale afspraken over toepassing van employability-instrumenten en -beleid.

- Faciliteiten:

Welke mogelijkheden bieden bedrijven aan werknemers om de employability te effectueren en/of uit te breiden?

- Communicatie:

In hoeverre zijn werknemers op de hoogte van de bestaande faciliteiten en in hoeverre waarderen zij deze?

Institutionele en fiscale kaders

Wat zijn de CAO-afspraken die de basis vormen van het employability-beleid van ondernemingen. Hierbij staat een aantal instrumenten centraal (zie ook: Arbeidsinspectie, 1999 en 2000), te weten:

Opleiding: $\quad$ Scholing, verbijzonderd naar:

- algemene scholing (nederlands op de werkvloer);

- functiegerichte scholing (leerlingwezen/BBL). 
Scholingsverlof, verbijzonderd naar:

- betaald verlof voor scholing;

- onbetaald verlof voor scholing;

- examenverlof en tijd sparen voor scholing.

Opleidingsplannen, verbijzonderd naar:

- persoonlijke opleidingsplannen (POP);

- bedrijfsopleidingsplan (BOP).

Afspraken omtrent de inrichting van een O\&O-fonds.

Mobiliteit en

inzetbaarheid: Motiverend beloningsbeleid, verbijzonderd naar:

- beloning expliciet gekoppeld aan mate van inzetbaarheid;

- beloning impliciet gekoppeld aan mate van inzetbaarheid via diploma-toeslagen, waarnemingstoeslagen en extra periodieken;

- functionerings- en beoordelingsgesprekken.

Om een helder beeld te krijgen van de bestaande sectorale institutionele kaders moet worden geïnventariseerd in hoeverre afspraken omtrent het gebruik van bovenstaande instrumenten per sector in CAO's zijn vastgelegd. Hierbij is het vanzelfsprekend eveneens noodzakelijk dat de verschillende CAO's gerelateerd worden aan de bedrijfssectoren, zoals die in de Standaard Bedrijfs Indeling van het CBS worden onderscheiden. In principe zal uitgegaan worden van 13 sectoren.

Naast de afspraken die in CAO's zijn vastgelegd bestaat er ook nog een aantal fiscale maatregelen die het voor werkgever en werknemer aantrekkelijk maken om te investeren in employability. De maatregelen zijn erop gericht bepaalde kosten, bijvoorbeeld voor scholing, aftrekbaar te maken van de loonbelasting of bepaalde inkomenscomponenten, bijvoorbeeld verlofspaarregelingen, vrij te stellen van belasting. $\mathrm{Bij}$ het in beeld brengen van de bestaande fiscale regelingen moeten allereerst de regelingen worden opgesomd, waarbij de doelgroep per regeling moet worden vermeld. Bovendien zouden gegevens per sector over het gebruik van fiscale voordelen met betrekking tot employability moeten worden gegenereerd.

Naast de afspraken op het gebied van genoemde instrumenten zal ook aandacht besteed moeten worden aan het belang van institutionele belemmeringen die het voor groepen werknemers en werkgevers moeilijk maken om aan de employability van bepaalde groepen werknemers te werken. Hierbij wordt gedacht aan bestaande VUT-regelingen die werkgevers en werknemers impliciete beperkingen opleggen bij het investeren in employability. VUT-regelingen ontmoedigen werknemers immers om op oudere leeftijd nog te beginnen aan opleidingstrajecten of functiewisselingen. In de wetenschap dat werknemers gebruik zullen maken van VUT-regelingen zullen ook werkgevers minder snel geneigd zijn nog te investeren in de ontwikkeling van oudere werknemers, omdat de tijd dat deze investering rendement kan opleveren te kort is. 


\section{Faciliteiten}

Wat gebeurt er binnen organisaties om de employability van werknemers te bevorderen?

Hierbij wordt gekeken naar de faciliteiten die door organisaties worden aangeboden. Het gaat dan om faciliteiten gericht op:

Mobiliteit, verbijzonderd naar:

- Voeren van loopbaan c.q. functioneringsgesprekken;

- Aanwezigheid van vacatures op intranet;

- Aanwezigheid van een mobiliteitscentrum, een arbeidspool of andere soortgelijke mobiliteitsondersteunende faciliteiten (loopbaanontwikkeling, personeelsplanning).

Opleiding:

- Aanwezigheid opleidingscentrum, scholingsaanbod.

Inzetbaarheid:

- Aanwezigheid van instrumenten gericht op functieroulatie;

- Aanwezigheid van flexibele arbeidspatronen (variabele werktijden, op- afroepcontracten, flexibele jaarroosters).

Leeftijdsbewust personeelsbeleid:

- Aanwezigheid van maatregelen specifiek gericht op het aan het werk houden van oudere werknemers. Dit leeftijdsbewust personeelsbeleid kan betrekking hebben op faciliteiten die gericht zijn op de mobiliteit, de opleidingsparticipatie en de inzetbaarheid van oudere werknemers.

ARBO-beleid c.q. verzuimbeleid:

- Aanwezigheid van maatregelen die erop gericht zijn de arbeidsomstandigheden te verbeteren om werknemers zo lang mogelijk inzetbaar te houden;

- Aanwezigheid van maatregelen gericht op het verkrijgen van inzicht in verzuimcijfers en achtergronden, alsmede begeleiding van verzuimenden en reïntegratie.

\section{Arbeid en zorg:}

- Aanwezigheid van mogelijkheden tot opvang van kinderen;

- Aanwezigheid van mogelijkheden om zorgverlof, ouderschapsverlof, kraamverlof, adoptieverlof en bindingsverlof op te nemen.

Het voeren van loopbaan- c.q. functioneringsgesprekken is voor de employability van werknemers van belang omdat in dergelijke gesprekken zaken aan de orde komen als toekomstbeeld, opleidingsplannen, tevredenheid e.d. Wanneer dergelijke gesprekken op een goed gestructureerde manier en regelmatig worden gevoerd bestaat er bij zowel werkgever als werknemer een helder beeld van de plannen en perspectieven van beiden. Omdat plannen en afspraken die tijdens een loopbaan- 
gesprek worden uitgewisseld goed worden gedocumenteerd, vormen dergelijke gesprekken een goede basis voor het door organisaties te voeren employability-beleid.

Ook inzicht in de mogelijkheden die werknemers worden geboden om tijdelijk of voor langere duur van functie te veranderen maakt het gemakkelijker om aan de slag te blijven. Het aanbieden van een vacaturebank op het intranet, die dagelijks of wekelijks wordt ververst, is een belangrijke maatregel om mobiliteitsmogelijkheden met het personeel te communiceren. Zicht op de mobiliteitsmogelijkheden binnen de eigen organisatie of daarbuiten maakt het voor werknemers gemakkelijker om uiting te geven aan hun loopbaanwensen om zo eventueel met enige regelmaat van functie te veranderen.

Mobiliteitsondersteunende faciliteiten, zoals bijvoorbeeld een mobiliteitscentrum, kunnen daarbij van groot belang zijn. Mobiliteitsondersteunende faciliteiten zijn faciliteiten die een organisatie inricht om de in-, door-, en uitstroom van personeel te coördineren. Wanneer een organisatie bijvoorbeeld van een mobiliteitscentrum gebruik maakt, maakt dat de mogelijkheden om de employability van de werknemers te verbeteren veel overzichtelijker. Mobiliteitsondersteunende faciliteiten vergemakkelijken derhalve het werken aan employability. Ook het voeren van beleid gericht op loopbaanontwikkeling en het gestructureerd vormgeven aan personeelsplanning zijn activiteiten van bedrijven die het bevorderen van de employability van werknemers faciliteren.

Bedrijven kunnen er toe besluiten een eigen opleidingscentrum op te zetten, om het scholingsaanbod eigenhandig te coördineren en er zo voor te zorgen dat die scholing die wordt aangeboden ook optimaal aansluit bij het werk dat werknemers binnen de organisatie verrichten. De aanwezigheid van een eigen opleidingscentrum maakt bovendien de drempel voor werknemers om een cursus te gaan volgen een stuk lager. Werknemers zullen daardoor eerder opleidingen volgen en dus beter in staat zijn hun kwalificaties 'up-to-date' te houden.

Om de inzetbaarheid van werknemers uit te breiden is het bovendien van belang dat binnen organisaties mogelijkheden worden geboden om tijdelijk een andere functie uit te oefenen, zodat werknemers voortdurend zicht hebben op de eigen kwaliteiten en interesses. Een van de belangrijkste manieren om werknemers te laten kennismaken met het werk in andere functies is de implementatie van instrumenten die erop gericht zijn functieroulatie te bevorderen.

Behalve naar instrumenten op het gebied van mobiliteit, opleiding en inzetbaarheid zijn er ook instrumenten die speciaal zijn ontwikkeld om de employability van specifieke groepen werknemers te faciliteren. Daarbij kan worden gedacht aan instrumenten die vallen onder het Leeftijdsbewust personeelsbeleid. Met name als gevolg van de doorzettende vergrijzing van de werkzame bevolking is het van belang instrumenten in te richten die erop gericht zijn vooral oudere werknemers voldoende 'employable' te houden. Omdat oudere werknemers niet altijd meer fysiek of mentaal in staat zijn om hun functie optimaal uit te oefenen, is het wenselijk hier zoveel mogelijk rekening mee te houden. Voert een bedrijf leeftijdsbewust personeelsbeleid 
dan duidt dat erop dat dit bedrijf zich serieus bezighoudt met de employability van specifieke leeftijdsgroepen.

Ook inzicht in het al dan niet structureel voeren van een ARBO-beleid c.q. verzuimbeleid is nodig om het inzicht in de effectueringscondities volledig te maken. Het voeren van een vorm van ARBO- c.q. verzuimbeleid duidt er immers op dat serieus wordt omgegaan met duurzame inzetbaarheid van werknemers.

Ten slotte is het van belang te kijken in hoeverre er binnen organisaties aandacht wordt besteed aan faciliteiten om arbeid en zorg te kunnen combineren. Het bieden van voorzieningen ter kinderopvang en het aanbod van (gedeeltelijk betaald) zorgverlof en ouderschapsverlof dragen ertoe bij dat de mogelijkheden om employable te zijn voor de groep werknemers die de zorg heeft voor kinderen worden verruimd.

\section{Communicatie}

Het is echter ook belangrijk in kaart te brengen in hoeverre de verschillende groepen werknemers toegang hebben tot genoemde instrumenten c.q. faciliteiten. Het is bijvoorbeeld van belang dat de faciliteiten die beschikbaar zijn om de employability van de werknemers te verbeteren bekend zijn bij individuele werknemers, zodat zij weten hoe zij hierop aanspraak kunnen doen gelden. Bovendien is het voor de werkgever van belang om te weten in hoeverre het personeel tevreden is over de aanwezige faciliteiten. Informatievoorziening staat centraal voor werknemer en werkgever.

Om de informatievoorziening in beeld te brengen moet worden gekeken naar een aantal zaken, te weten:

- Inzicht in de toekomstperspectieven van de huidige functie;

- Bekendheid met eventuele vacaturesites op het intranet;

- Aanwezigheid van opleidingscatalogi;

- Uitvoeren van tevredenheidsonderzoek onder werknemers.

\subsection{Employability model voor niet-werkenden}

\subsubsection{Conceptueel model}

Voor het in kaart brengen van de employability van degenen die (nog) geen deel uitmaken van de werkzame beroepsbevolking moet primair worden gekeken naar hun intredekans op de arbeidsmarkt: de kans op het verkrijgen van een baan. Omdat bepaalde groepen niet-werkenden verschillende motieven hebben om niet actief te zijn op de arbeidsmarkt is het van belang een aantal groepen niet-werkenden te onderscheiden. Hierbij gaat het met name om de volgende groepen:

- Niet-werkende werkzoekenden;

- Niet-participerenden. 
Met niet-werkende werkzoekenden wordt de groep niet-werkenden bedoeld die op het moment niet werkt of minder dan twaalf uur per week werkt, maar wel op zoek is naar een baan voor 12 uur of meer. De meeste niet-werkende werkzoekenden staan ingeschreven bij Arbeidsvoorziening. De groep niet-werkende werkzoekenden wordt door Arbeidsvoorziening onderverdeeld in vier groepen of fases, te weten:

- Fase 1: werkzoekenden voor wie arbeidsmarktinstrumenten beschikbaar zijn, gericht op directe bemiddeling of terugkeer naar de arbeidsmarkt. Zij zijn dus direct bemiddelbaar.

- Fase 2: werkzoekenden voor wie arbeidsmarktinstrumenten beschikbaar zijn, gericht op een zodanige verbetering van de kans op werk, dat zij binnen een tijdsbestek van maximaal één jaar als werkzoekende bemiddelbaar zijn op de arbeidsmarkt.

- Fase 3: werkzoekenden voor wie arbeidsmarktinstrumenten beschikbaar zijn, gericht op een zodanige verbetering van de kans op werk, dat zij binnen een tijdsbestek van meer dan één jaar als werkzoekende bemiddelbaar zijn op de arbeidsmarkt

- Fase 4: werkzoekenden die vanwege zware persoonlijke werkbelemmeringen zijn aangewezen op hulp en zorg die gericht is op een zodanige verbetering van hun positie dat pas op termijn arbeidsmarktinstrumenten inzetbaar zijn die gericht zijn op verbetering van hun kans op werk.

Behalve de groep werkzoekenden bestaat er ook een omvangrijke 'stille reserve'. Binnen deze stille reserve zal geprobeerd worden, drie groepen niet-participerenden te onderscheiden, die elk een aparte benadering verdienen:

- Niet-participerenden met een werkende partner;

- Niet-participerenden met een bepaalde arbeidshandicap;

- Niet-participerende vijftigplussers.

Niet-participerenden met een werkende partner hebben doorgaans zorgtaken binnen het eigen gezin waardoor zij vaak geen of weinig behoefte hebben om in te treden op de arbeidsmarkt. Deels zal dit echter wel beïnvloed worden door de condities waaronder men betaald werk zou kunnen verrichten. Daarbij kan worden gedacht aan aangepaste werktijden, kinderopvang, zorgverlof, e.d.

Veel (gedeeltelijk) arbeidsgehandicapten zouden wel willen werken, maar zij kunnen op grond van hun arbeidshandicap vaak moeilijk werk vinden. Ook bestaat er een grote groep niet-werkende vijftigplussers die vanwege vroegtijdige pensionering en dergelijke vrijwel geen financiële prikkels meer heeft om zich aan te bieden op de arbeidsmarkt. Als Niet-participerende vijftigplussers nog wel de wil hebben aan de slag te gaan dan krijgen zij hier vaak op grond van hun leeftijd nauwelijks kansen voor.

Mede als gevolg van de toenemende krapte op de arbeidsmarkt is het voor werkgevers steeds interessanter een goed inzicht te krijgen in de kwalificaties van deze drie groepen potentiële werknemers. Aan de hand van dit inzicht kan immers 24 
duidelijk worden gemaakt op welke groepen niet-werkenden werkgevers hun wervingsbeleid zouden kunnen richten en wat precies de belemmeringen zijn die zouden moeten worden weggenomen om deze groepen werkenden op termijn toch een volwaardige plek op de arbeidsmarkt te bezorgen. Zo kan het aanpassen van werkplekken betekenen dat niet-werkenden met een bepaalde arbeidshandicap kunnen worden geactiveerd.

Figuur 2.2 geeft een overzicht van het conceptuele model dat de basis vormt voor het monitoren van de employability van de niet-werkenden.

Figuur 2.2

Employability Monitor: model niet-werkenden

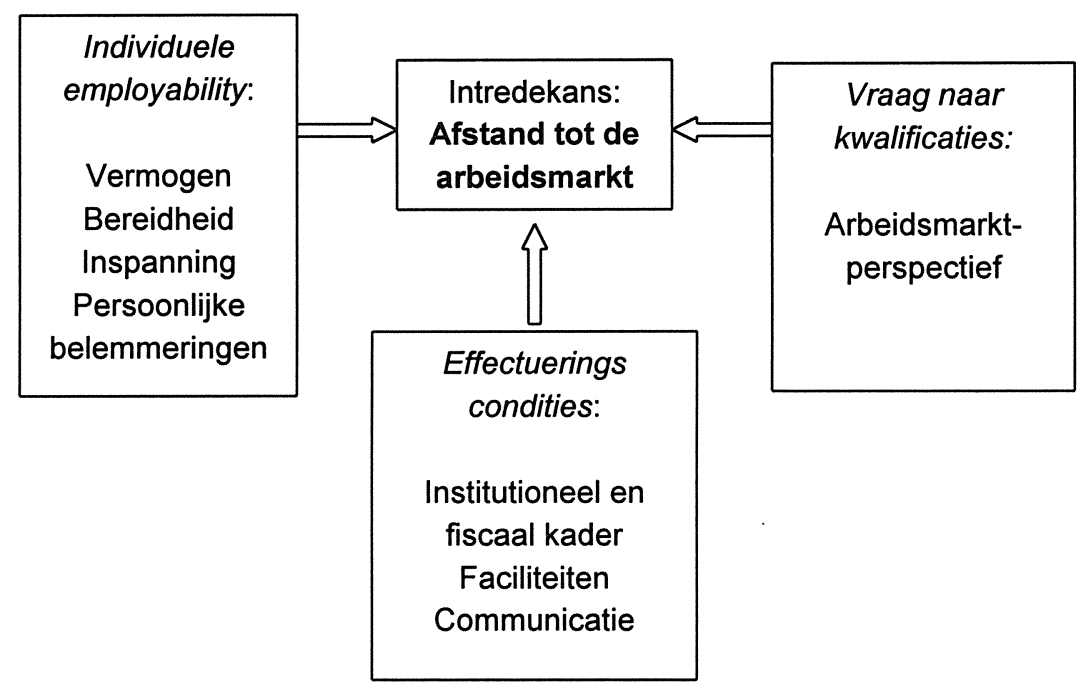

De employability van de niet-werkenden spitst zich, zoals gezegd, toe op de intredekans op de arbeidsmarkt die sterk gerelateerd is aan iemands 'afstand tot de arbeidsmarkt'. Deze intredekans is afhankelijk van zowel persoonskenmerken als van de kansen die de arbeidsmarkt mensen biedt. Naast deze 'vraag-aanbod' vergelijking met betrekking tot de employability van de niet-werkenden zijn ook de wettelijke en fiscale regelingen, faciliteiten en de bekendheid daarmee van groot belang om de arbeidsmarktintrede van niet-werkenden te stimuleren en de intredekansen op de arbeidsmarkt te vergroten.

Uitgangspunt bij het bepalen van de employability van niet-werkenden is, net als dat bij werknemers het geval is, de individuele employability. Hierbij gelden wederom de vermogens, bereidheid, inspanningen en persoonlijke belemmeringen als bepalende factoren. Is de individuele employability bekend dan wordt vervolgens gekeken naar de vraag naar de kwalificaties die een niet-werkende te bieden heeft, met andere woorden: het arbeidsmarktperspectief. Hierbij wordt in eerste instantie uitgegaan van de arbeidsmarktperspectieven op korte termijn op grond van iemands opleidingsachtergrond. 
Wanneer de afstand tot de arbeidsmarkt bekend is, door een vergelijking te maken tussen de individuele employability van de niet-werkenden en de vraag naar de kwalificaties waarover zij beschikken, is het van belang een helder beeld te hebben van de mogelijkheden om die afstand te overbruggen. We kunnen hier weer spreken van de effectueringcondities. Dit vereist een overzicht van de institutionele kaders die het mogelijk maken iemands employability te verbeteren en de faciliteiten die er voor niet-werkenden beschikbaar zijn om hun kans op werk te vergroten. Ten slotte zou in kaart moeten worden gebracht in hoeverre niet-werkenden op de hoogte zijn van de mogelijkheden om van dergelijke faciliteiten gebruik te maken.

Dit conceptuele model, dat als houvast kan dienen bij de monitoring van de employability van niet-werkenden, zal hieronder verder worden besproken. Waar nodig zal bovendien worden ingegaan op specifieke aandachtspunten voor bepaalde groepen niet-werkenden (niet-werkende werkzoekenden, niet-participerende (gedeeltelijk) arbeidsgehandicapten, niet-participerenden met een werkende partner en niet-participerende 50-plussers).

\subsubsection{Individuele employability van niet-werkenden}

Om de individuele employability van niet-werkenden in beeld te brengen moet in principe worden uitgegaan van dezelfde vier aspecten als bij de individuele employability van werknemers. Hierbij gaat het om de volgende vier vragen:

Wat kan de niet-werkende (vermogen)?

Wat wil de niet-werkende (bereidheid)?

Wat doet de niet-werkende feitelijk (inspanning)?

Wat belemmert de niet-werkende om in te treden (persoonlijke belemmeringen)?

Wat kan de niet-werkende?

Voor het in beeld brengen van iemands kans op werk is het vanzelfsprekend in de eerste plaats van belang vast te stellen wat iemand eigenlijk kan. Ook van niet-werkenden kunnen de vermogens het beste in beeld worden gebracht door te kijken naar de kwalificaties die men op dit moment heeft. Allereerst wordt dus wederom gekeken naar de initiële opleiding van niet-werkenden. Daarnaast is het belangrijk om te kijken naar de vervolgopleidingen en cursussen die men heeft gevolgd en de competenties waarover men beschikt. Ten slotte wordt gekeken naar de werkervaring die niet-werkenden in het verleden hebben opgedaan. Om een compleet beeld te krijgen van wat een niet-werkende kan, is het tenslotte ook van belang het intredevermogen, mobiliteitsvermogen, opleidingsvermogen en het vermogen zich kwantitatief breed in te zetten te monitoren.

Het intredevermogen van niet-werkenden wordt gedefinieerd als het vermogen direct in te treden op de arbeidsmarkt. Hierbij staat de vraag centraal in hoeverre niet-werkenden in staat zijn om per direct aan de slag te gaan. 
Het mobiliteitsvermogen van niet-werkenden kan het best worden bepaald aan de hand van hun opleiding en werkervaring. De mate waarin sprake is van ervaringsconcentratie (eenzijdige werkervaring) bepaalt of en in hoeverre iemand in staat is in verschillende functies te gaan werken.

Het opleidingsvermogen kan, net als dat voor werknemers het geval is, worden bepaald aan de hand van het totaal aantal jaren dat iemand met scholing bezig is geweest. Hierbij tellen alleen afgesloten opleidingen mee. Uitgangspunt hierbij is de hoogst genoten opleiding.

Het vermogen zichzelf kwantitatief breed in te zetten heeft betrekking op de vraag of men in staat is op onregelmatige tijden te werken en zowel fulltime als parttime te werken. Als dat het geval is zal men in principe voor meer functies in aanmerking kunnen komen.

Een belangrijk verschil met het conceptuele model dat als raamwerk dient om de employability van werknemers in beeld te brengen, is dat bij het in beeld brengen van het employability vermogen van niet-werkenden ook gekeken moet worden naar de periode van inactiviteit. Bij het vaststellen van de aanwezige kwalificaties wordt voor niet-werkenden rekening gehouden met de periode waarin zij eerder verworven kwalificaties niet hebben gebruikt. Het niet gebruiken van kwalificaties leidt immers in de meeste gevallen tot kwalificatieveroudering. Men spreekt in dit verband wel van 'atrofie' (zie ook: ROA, 2000).

\section{Wat wil de niet-werkende?}

Bij het bepalen van de employability-bereidheid van niet-werkenden moet vanzelfsprekend allereerst gekeken worden naar de bereidheid om te willen werken: de intredebereidheid. Om een duidelijk beeld te kunnen schetsen van wat een nietwerkende wil moet in eerste instantie worden gekeken naar de wensen die nietwerkenden hebben ten aanzien van hun toekomstige functie. Een viertal aspecten staat daarbij centraal, te weten:

- functionele mobiliteitsbereidheid;

- geografische mobiliteitsbereidheid;

- opleidingsbereidheid;

- bereidheid tot een brede kwantitatieve inzetbaarheid.

Behalve over de intredebereidheid is dus allereerst informatie gewenst over de verscheidenheid aan functies die iemand in principe zou willen vervullen. Dit kan worden aangeduid als de functionele mobiliteitsbereidheid. Naarmate een niet-werkende zich meer beperkt in het aantal functies dat hij of zij zou willen bekleden zal de kans op intrede kleiner zijn.

Naast de functionele mobiliteitsbereidheid is van belang helder in beeld te hebben in hoeverre niet-werkenden eisen stellen aan de plaats waar zij willen gaan werken. Dit wordt aangeduid als de geografische mobiliteitsbereidheid. Wanneer een niet-wer- 
kende niet bereid is te verhuizen voor het aanvaarden van een functie dan kan dat een handicap zijn voor het verkrijgen van een plek op de arbeidsmarkt.

De opleidingsbereidheid van niet-werkenden is van belang om te kunnen bepalen in hoeverre niet-werkenden bereid zijn extra scholing te volgen om de afstand tot de arbeidsmarkt te overbruggen. Met name in het geval dat niet-werkenden een aantal jaren niet actief zijn geweest op de arbeidsmarkt is opleidingsbereidheid vaak van groot belang. De niet-werkenden hebben immers te maken met een zekere kwalificatieveroudering die het hun moeilijk maakt direct in te treden.

Om de bereidheid tot een brede kwantitatieve inzetbaarheid in beeld te krijgen moet worden gekeken naar de bereidheid van niet-werkenden op onregelmatige tijden te werken. Daarnaast is de bereidheid van niet-werkenden om zowel partime als fulltime te gaan werken van belang. Is iemand immers bereid zowel in deeltijd als voltijds te werken dan bevordert dit de kansen op werk.

\section{Wat doet de niet-werkende feitelijk?}

In aanvulling op het in kaart brengen van de verschillende aspecten van het vermogen en de bereidheid van niet-werkenden om aan betaald werk te komen, moet ook worden gekeken naar de inspanningen die niet-werkenden daadwerkelijk leveren om aan een baan te komen. Hierbij wordt in de eerste plaats gekeken naar de inspanningen die een niet-werkende in het algemeen levert om aan werk te komen: de intrede-inspanning. In aanvulling daarop moet worden gekeken naar de inspanningen die niet-werkenden leveren met betrekking tot hun functionele mobiliteit, het volgen van opleiding en hun kwantitatieve inzetbaarheid.

Voor werkzoekenden zijn inspanningen om aan werk te komen vrij eenvoudig vast te stellen, omdat voor deze groep meestal geldt dat zij een sollicitatieverleden hebben. Voor de 'stille reserve' is het weinig zinvol een beeld te creëren van inspanningen, omdat zij zich (bijna per definitie) niet zelf inspannen om werk te vinden maar veeleer naar de arbeidsmarkt toegetrokken zullen moeten worden.

Voor niet-werkende werkzoekenden staat dus allereerst het sollicitatiegedrag centraal. Op basis hiervan kan worden bepaald in hoeverre een werkzoekende daadwerkelijk acties onderneemt om de afstand tot de arbeidsmarkt te overbruggen. In eerste instantie gaat het daarbij om de intrede-inspanning in het algemeen: zoekt men daadwerkelijk naar een baan. Daarnaast moet worden gekeken naar de verscheidenheid aan functies waarop een niet-werkende solliciteert: de functionele mobiliteitsinspanningen.

Vanzelfsprekend zijn ook de opleidingsinspanningen van de niet-werkenden van belang. Wanneer een werkzoekende deelneemt aan een opleiding gericht op een toekomstige functie, zal dit de afstand tot de arbeidsmarkt kleiner maken. Hierbij kan men zowel denken aan vakspecifieke bij- of omscholing, als aan sollicitatietrainingen en dergelijke. 
Ten slotte kan aan de hand van het sollicitatiegedrag van werkzoekenden nog worden bepaald in hoeverre zij zich inspannen op het gebied van de brede kwantitatieve inzetbaarheid. Solliciteert een werkzoekende naar zowel deeltijd als voltijdfuncties en/of naar functies met onregelmatige werktijden, dan duidt dit erop dat een werkzoekende inspanningen levert om kwantitatief breed inzetbaar te zijn.

\section{Wat zijn de persoonlijke belemmeringen?}

Met name voor niet-werkenden spelen persoonlijke belemmeringen vaak een centrale rol bij het bepalen van de afstand tot de arbeidsmarkt. De belemmeringen die een rol spelen zijn per categorie niet-werkenden waarschijnlijk heel verschillend en gekoppeld aan de reden van inactiviteit. Voor niet-werkende vijttigplussers zal voornamelijk de leeftijd bepalend zijn $^{5}$, terwijl voor (gedeeltelijk) arbeidsgehandicapten vooral de handicap hen van de arbeidsmarkt houdt. Naast de leeftijd en eventuele fysieke of psychische problemen kan ook de gezinssituatie een belangrijke rol spelen. Dit laatste zal vooral het geval zijn bij de niet-participerende vrouwen met werkende partner.

Arbeidsvoorziening beschrijft een groot aantal factoren die de afstand tot de arbeidsmarkt in meer of mindere mate beïnvloeden:

- leeftijd;

- presentatie (voorkomen);

- zelfredzaamheid;

- sollicitatievaardigheden;

- motivatie;

- medische aspecten;

- onduidelijke beroepswens;

- reëel zelfbeeld;

- flexibiliteit;

- zorgtaken;

- psychische problemen;

- alcohol/drugs;

- financiële problemen;

- huisvesting.

Op een aantal punten overlapt deze lijst met eerder genoemde aspecten van het employability vermogen (bijvoorbeeld zelfredzaamheid, sollicitatievaardigheden) of de employability bereidheid (intrede, flexibiliteit). We zullen ons daarom bij het in kaart brengen van de mogelijke persoonlijke belemmeringen die niet-werkenden hebben om betaald werk te kunnen krijgen, concentreren op een tweetal factoren: de gezinssituatie en het eventueel hebben van een arbeidshandicap. Bij persoonlijke belemmeringen vanwege de gezinssituatie is vooral de zorg die men heeft voor thuiswonende kinderen van belang. Niet-werkenden met een arbeidshandicap kun-

5. Veel vrouwen in deze leeftijdscategorie hebben bovendien als extra belemmering dat men reeds lange tijd (sinds het begin van het huwelijk of het krijgen van kinderen) geen betaald werk heeft verricht. 
nen moeilijkheden ondervinden om bepaalde functies, zonder aanvullende faciliteiten, goed te vervullen. Persoonlijke problemen met de Nederlandse taal worden reeds bij het competentiebegrip meegenomen.

Op basis van deze belemmeringen kan voor niet-werkenden worden bepaald wat hen ertoe brengt zich niet aan te bieden op de arbeidsmarkt of wat hen in de weg staat bij intrede.

\subsubsection{Arbeidsmarktperspectieven}

Om te kunnen bepalen in hoeverre er behoefte bestaat aan niet-werkenden met bepaalde kwalificaties is het van belang de arbeidsmarktperspectieven op korte termijn te bepalen. Voor de verschillende groepen niet-werkenden moet daarbij worden uitgegaan van de arbeidsmarktperspectieven op basis van hun opleidingsachtergrond. Indien mogelijk kan vervolgens ook nog worden gekeken naar de perspectieven van de verschillende beroepen die een niet-werkende met een gegeven opleidingsachtergrond zou kunnen uitoefenen.

\subsubsection{Effectueringscondities}

Om de afstand tot de arbeidsmarkt van niet-werkenden te verkleinen staat een aantal wegen open. Wat de juiste weg is om die afstand te verkleinen is afhankelijk van de vastgestelde tekortkomingen en belemmeringen van niet-werkenden. Schieten hun employability-vermogens te kort of zijn deze ernstig verouderd, dan is herscholing een geschikt instrument. Heeft een niet-werkende niet de juiste opleidingsachtergrond dan ligt omscholing meer voor de hand. Beheerst een niet-werkende de Nederlandse taal in onvoldoende mate, dan is een taalcursus een eerste vereiste. Zo zou er voor elke mogelijke belemmering een oplossingsinstrument moeten zijn. Onder de noemer effectueringcondities komen de instrumenten aan de orde die momenteel beschikbaar zijn.

Bovendien is het van belang te bezien in hoeverre niet-werkenden op de hoogte zijn van het bestaan van dergelijke instrumenten. Ten slotte zal inzicht moeten worden verkregen in institutionele en fiscale kaders die het al dan niet gemakkelijker maken om de arbeidsmarkt te betreden.

Evenals dat bij het bezien van de employability van werknemers het geval was wordt ook voor niet-werkenden uitgegaan van een drietal dimensies, te weten:

\section{- Institutioneel en fiscaal kader.}

Wat is de centrale wet- en regelgeving omtrent het verbeteren van de employability van niet-werkenden en welke fiscale maatregelen bestaan er om de intrede van specifieke groepen niet-werkenden te stimuleren?

- Faciliteiten:

Welke faciliteiten worden er geboden om de afstand tot de arbeidsmarkt te verkleinen? 
- Communicatie:

In hoeverre zijn niet-werkenden op de hoogte van de bestaande instrumenten?

Institutioneel en fiscaal kader

Afhankelijk van iemands afstand tot de arbeidsmarkt is een groot aantal instrumenten beschikbaar en is een even groot aantal fiscale maatregelen getroffen om deze afstand te verkleinen. Een belangrijk deel van deze instrumenten en maatregelen kent een wettelijk kader. Het is van belang te bezien wat voor maatregelen er bestaan en voor wie zij bedoeld zijn. Dit geeft een helder beeld van mogelijkheden die niet-werkenden hebben om de afstand tot de arbeidsmarkt te verkleinen.

\section{Faciliteiten}

Het is voor de groep niet-werkenden niet altijd vanzelfsprekend dat zij intreden op de arbeidsmarkt, zodat hiertoe een en ander aan faciliteiten geboden zal moeten worden. De geboden faciliteiten zouden voor bepaalde groepen niet-werkenden belemmeringen kunnen wegnemen, zodat zij steeds meer belangstelling hebben om in te treden. Het aanbieden van dergelijke faciliteiten dient in eerste instantie te gebeuren door potentiële werkgevers, die uit de groep niet-werkenden werknemers willen werven. Deze werkgevers zijn genoodzaakt bepaalde voorzieningen te treffen om aantrekkelijk te zijn voor niet-werkenden. Het bieden van kinderopvang is bijvoorbeeld een faciliteit, die het voor niet-werkende gehuwde personen met kinderen aantrekkelijker maakt om in te treden. Het aanpassen van de werkplek om intrede van (gedeeltelijk) arbeidsgehandicapten mogelijk te maken is een ander voorbeeld.

In dit verband zijn vanzelfsprekend ook de trajecten die door bijvoorbeeld Arbeidsvoorziening of de uitvoeringsinstanties voor de sociale zekerheid (UVI's) worden aangeboden om de afstand tot de arbeidsmarkt voor niet-werkende werkzoekenden te verkleinen van groot belang. Werkzoekenden kunnen via Arbeidsvoorziening bijvoorbeeld aanspraak maken op een groot aantal instrumenten die erop gericht zijn werkzoekenden te reïntegreren. Afhankelijk van de afstand tot de arbeidsmarkt staan dergelijke regelingen open. Werkzoekenden die in fase 1 worden ingedeeld en dus direct bemiddelbaar zijn, krijgen van Arbeidsvoorziening alleen de basisdienstverlening. Werkzoekenden die weliswaar bemiddelbaar zijn, maar daarbij wel behoefte hebben aan een bepaald reïntegratietraject kunnen, bijvoorbeeld via Arbeidsvoorziening, hun intredekans op de arbeidsmarkt vergroten.

De regelingen en instrumenten en de omvang van de middelen die beschikbaar zijn voor de reïntegratie van de verschillende groepen niet-werkenden bepalen in hoeverre er mogelijkheden zijn om de bestaande afstand tot de arbeidsmarkt te verkleinen.

\section{Communicatie}

Het bestaan van een veelheid aan op de intrede op de arbeidsmarkt gerichte instrumenten is op zich onvoldoende om niet-werkenden te activeren. Niet-werkenden 
moeten op de hoogte zijn van het bestaan van de instrumenten. Bovendien is het van belang meer zicht te hebben op de mate waarin werkgevers op de hoogte zijn van de belemmeringen die er bestaan bij niet-werkenden om aan de slag te gaan. Dit stelt hen immers in staat om de juiste faciliteiten te bieden. Ten slotte is het van belang dat werkgevers op de hoogte zijn van de bestaande regelingen en fiscale maatregelen die de drempel verlagen om mensen uit groepen met een van oudsher verzwakte arbeidsmarktpositie in dienst te nemen. Zijn werkgevers immers slecht op de hoogte van het bestaan van dergelijke maatregelen dan betekent dit een extra drempel voor de arbeidsmarktintrede van niet-werkenden. 


\section{Inventarisatie van bruikbare databronnen}

In voorgaande hoofdstukken is duidelijk geworden hoe de verschillende aspecten van employability van werkenden en niet-werkenden het beste zouden kunnen worden gemonitord. In dit hoofdstuk zal een globaal beeld worden gegeven van de mate waarin dit met bestaande databronnen ook daadwerkelijk mogelijk is. In het kort zal worden ingegaan op de beschikbare databronnen en de betekenis die zij kunnen hebben voor de Employability Monitor. Uitgangspunt hierbij is de mate waarin bepaalde databronnen gegevens opleveren aan de hand waarvan het mogelijk is op een betrouwbare manier de verschillende dimensies van de conceptuele modellen in beeld te brengen. Per databron zal, behalve een korte toelichting op de manier van dataverzameling, het steekproefkader en de periodiciteit telkens worden aangegeven voor welke dimensie in het conceptuele model de desbetreffende databron gebruikt zou kunnen worden. In het volgende hoofdstuk wordt verder ingegaan op de indicatoren die bij de invulling van de monitor kunnen worden gebruikt. Daar zal ook worden aangegeven wat de lacunes zijn in de bestaande databronnen.

In paragraaf 3.1 wordt een korte toelichting gegeven op de databronnen die zijn gescand op mogelijk bruikbare informatie voor de Employability Monitor. In paragraaf 3.2 wordt per employability-dimensie aangegeven welke databron de meest interessante is voor de desbetreffende dimensie.

\subsection{Inventarisatie beschikbare databronnen}

\section{OSA-Aanbodpanel}

Het arbeidsaanbodpanel van de OSA (Organisatie voor Strategisch Arbeidsmarktonderzoek) is een meetinstrument waarmee periodiek gegevens worden verzameld over de (potentiële) beroepsbevolking in Nederland. Het panelonderzoek bestaat uit tweejaarlijkse enquêtes onder huishoudens en is gericht op personen in de leeftijdscategorie van 16 tot 65 jaar die geen dagonderwijs volgen. De vragen die worden gesteld hebben voornamelijk betrekking op de positie die men inneemt op de arbeidsmarkt en het arbeidsmarktgedrag. In het aanbodpanel wordt getracht surveyen panelonderzoek te combineren. Dit betekent, dat geprobeerd wordt in elke nieuwe enquête alle huishoudens van de vorige meting opnieuw te benaderen. Bovendien worden non-responderende huishoudens zoveel mogelijk vervangen door nieuwe huishoudens die op een aantal centrale criteria (leeftijdsverdeling, geslacht, gezinsgrootte en regio) gelijkwaardig zijn aan de non-respondenten. In de huishoudens wordt in elk geval altijd de hoofdkostwinner geënquêteerd.

Voor de peiling van 1998 (de achtste 'golf') zijn gesprekken gevoerd met 4.780 personen die behoorden tot $\mathbf{2 . 5 7 2}$ huishoudens. Elke twee jaar wordt van ongeveer 4.700 personen informatie verzameld. Het cohort, de groep respondenten die deel uitmaakt van het aanbodpanel, bestaat uit ruim 1.500 respondenten. In het uitein- 
delijke databestand behoort ruim $70 \%$ van de respondenten tot de werkzame beroepsbevolking. $3 \%$ is werkloos ${ }^{6}$ en $27 \%$ behoort niet tot de beroepsbevolking.

Het OSA-Aanbodpanel levert zowel informatie over de werkzame beroepsbevolking, als over werkzoekenden en niet-participerenden. Voor deze beide laatstgenoemde groepen is echter, als gevolg van de routing in de vragenlijsten, de verzamelde informatie veel minder uitgebreid dan voor de werkenden. Het OSA-Aanbodpanel levert onder andere informatie op de volgende gebieden:

- persoonskenmerken;

- arbeidsparticipatie;

- Ionen, inkomsten en secundaire arbeidsvoorwaarden;

- arbeidsomstandigheden en ziekteverzuim;

- zoekgedrag en arbeidsmobiliteit;

- gevolgd onderwijs en scholing;

- flexibele arbeid.

Het OSA-Aanbodpanel is voor de Employability Monitor met name interessant op het terrein van de individuele employability van werknemers. De survey bevat een groot aantal variabelen dat het mogelijk maakt individuele vermogens, bereidheid, inspanningen en belemmeringen inzichtelijk te maken. Zoals gezegd, is de informatie die wordt verzameld over niet-werkenden en niet-participerenden summier. Niettemin biedt de survey ook voor deze groepen enkele interessante gegevens. Het OSAAanbodpanel maakt ook een verbijzondering naar bedrijfsgrootte mogelijk, zodat informatie over employability-aspecten in het midden- en kleinbedrijf eventueel ook beschikbaar is. Kanttekening hierbij is dat werknemers niet altijd exact zicht hebben op de omvang van de organisatie waarvoor zij werken, zodat vraagtekens kunnen worden geplaatst bij de betrouwbaarheid van de data.

\section{OSA-Arbeidsvraagpanel}

Het OSA-Arbeidsvraagpanel is een tweejaarlijks panelonderzoek onder bedrijven en instellingen in Nederland. Aan de peiling van 1997 hebben ruim 2.500 organisaties deelgenomen. Er wordt bij deze peiling gebruik gemaakt van twee typen vragenlijsten, een vragenlijst voor zorginstellingen (ongeveer 400 respondenten) en een vragenlijst voor overheidsinstellingen, onderwijsorganisaties en overige organisaties (ongeveer 2.100 respondenten). De onderzoekspopulatie van het arbeidsvraagpanel wordt gevormd door arbeidsorganisaties in Nederland met minimaal 5 werknemers. De informatie wordt verzameld via mondelinge en schriftelijke vragenlijsten. Vanzelfsprekend biedt het arbeidsvraagpanel geen mogelijkheden om uitspraken te doen over de employability van niet-werkenden.

6. Werkloosheid wordt hier gedefinieerd op basis van de CBS-definitie van de werkloze beroepsbevolking. Werkloos zijn houdt in dit geval in dat een persoon helemaal niet of minder dan 12 uur per week werkt, terwijl dezelfde persoon wel tenminste 12 uur wil werken, beschikbaar is en activiteiten ontplooit om aan het werk te komen. 
Met het OSA arbeidsvraagpanel wordt beoogd inzicht te krijgen in:

- organisatiekenmerken;

- ontwikkeling van de werkgelegenheid;

- veranderingen in het personeelsbestand;

- personeelsbeleid;

- arbeidsvoorwaarden;

- arbeidsomstandigheden en ziekteverzuim;

- arbeidstijdpatronen en flexibiliteit;

- ongeschoold werk;

- internationalisering.

Het OSA-Arbeidsvraagpanel is voor de Employability Monitor met name een belangrijke bron van informatie op het gebied van de behoefte aan employability en de effectueringscondities. Het OSA Arbeidsvraagpanel levert data die het mogelijk maken inzicht te krijgen in de mate waarin zich bepaalde ontwikkelingen voordoen binnen organisaties, of in de directe context waarin ze opereren. Bovendien kan met de data een beeld worden geschetst van de faciliteiten die organisaties hun personeel bieden, gericht op het verbeteren van de employability van werknemers. Net als in het OSA-Aanbodpanel wordt in het OSA-Arbeidsvraagpanel gevraagd naar de omvang van de organisatie. Bij gebruikmaking van het OSA-Arbeidsvraagpanel is het dus ook mogelijk informatie te verzamelen over het midden- en kleinbedrijf, al blijven de ondernemingen met minder dan 5 werknemers buiten beschouwing. Omdat de vragen worden gesteld aan vertegenwoordigers van organisaties lijkt de betrouwbaarheid van de gegevens over bedrijfsgrootte in dit bestand gewaarborgd.

\section{Enquête Beroepsbevolking CBS}

De Enquête Beroepsbevolking (EBB) van het CBS is een continu enquêteonderzoek dat sinds 1987 wordt gehouden onder personen van 15 jaar of ouder die in Nederland wonen. Personen in inrichtingen, instellingen en tehuizen ('institutionele bevolking') zijn uitgesloten. De steekproef is een zogenaamde gestratificeerde meertrapssteekproef en bestaat uit circa 115.000 adressen. De respons hierop is jaarlijks ongeveer 66.000 adressen. In personen is de respons ruim 90.000 per jaar. Van deze totale respons is het merendeel (ruim 85\%) tussen de 15 en 65 jaar oud. De rest is ouder dan 65 jaar.

De vragen die in de EBB aan de orde komen kunnen worden onderverdeeld in een aantal categorieën, namelijk:

- persoonskenmerken;

- werkkring en arbeidsmarktsituatie;

- gevolgd onderwijs en scholing;

- uitkering/pensioen;

- arbeidsomstandigheden;

- flexibele arbeid;

- binding met de arbeidsmarkt. 
De Enquête Beroepsbevolking is als databron voor de Employability Monitor met name interessant voor het in beeld brengen van verschillende aspecten van de individuele employability van zowel werknemers als niet-werkenden. Ook maakt de EBB het mogelijk een beeld te krijgen van de employability in het midden- en kleinbedrijf, zij het dat de informatie omtrent bedrijfsgrootte niet altijd even accuraat is. De EBB is een persoonsvragenlijst en het is individuen niet altijd bekend wat de omvang is van de organisatie waarvoor zij werken. De ene persoon neemt immers alleen de eigen vestiging als uitgangspunt, waar een ander ook werknemers bij andere vestigingen meerekent.

\section{Sociaal Economisch Panelonderzoek (CBS)}

In 1984 is het Centraal Bureau voor de Statistiek gestart met het Sociaal-economisch panelonderzoek (SEP). In dit onderzoek worden circa 5.000 huishoudens in de tijd gevolgd. Daarvoor worden alle huishoudleden van 16 jaar of ouder met tussenpozen ondervraagd over onderwerpen die betrekking hebben op de sociaal-economische situatie van het huishouden en van de personen zelf. Tot 1990 werden jaarlijks twee peilingen gehouden, in april en oktober. Vanaf dat jaar worden huishoudens een keer per jaar, in april, benaderd.

In het SEP wordt onder andere beoogd inzicht te krijgen in:

- persoonskenmerken;

- gevolgde opleiding en scholing;

- arbeid;

- inkomen;

- arbeidsmobiliteit.

Afhankelijk van de aard van het onderwerp worden vragen gesteld aan een persoon uit het huishouden (bij voorkeur het hoofd) of aan alle tot het huishouden behorende personen van 16 jaar en ouder. In 1996 is de negentiende peiling van het SEP uitgevoerd. Het databestand SEP $1996^{7}$ omvat 12.897 personen, waarvan er 9.938 16 jaar of ouder zijn. Van deze laatste groep hebben 9.277 personen een persoonsvragenlijst ingevuld. Het totaal aantal steekproefpersonen van 12.897 maakt deel uit van in totaal 5.199 huishoudens. De vragen in het SEP die betrekking hebben op de onderwerpen arbeid, onderwijs, waardering persoonlijke omstandigheden en inkomen worden alleen gesteld aan leden van het huishouden die op de peildatum 16 jaar of ouder zijn.

De bruikbaarheid van het SEP-bestand voor de Employability Monitor ligt met name op het gebied van de individuele employability van de werknemers en de niet-werkenden. Het SEP dekt echter slechts een paar deelaspecten van deze dimensie af, zodat de bruikbaarheid van het bestand niet al te groot lijkt. Met het SEP-bestand is het overigens ook mogelijk inzicht te krijgen in enkele aspecten van de individuele

7. Afgezien van kleine veranderingen in het aantal respondenten dat mee heeft gedaan aan de enquêtes is er inhoudelijk de laatste jaren nagenoeg niets veranderd aan de SEPvragenlijst. 
employability verbijzonderd naar bedrijfsgrootte. Zo zijn analyses voor het MKB ook mogelijk.

\section{Continuing Vocational Training Survey 2 (CBS/Eurostat)}

In navolging van het door de Europese Commissie gefinancierde 'Continuing Vocational Training Survey', dat in 1993 plaatsvond in alle landen van de Europese Gemeenschap, is het CBS in het voorjaar van 1999 gestart met een vervolg op deze survey. In 2000 zal het daadwerkelijke onderzoek plaatsvinden en vanaf 2001 zijn data beschikbaar via Eurostat. De centrale doelstelling van het onderzoek is het verzamelen van gegevens over de omvang, samenstelling en kenmerken van opleidingsactiviteiten, die particuliere bedrijven ondernemen ten behoeve van hun werknemers. Hierbij gaat het niet alleen om interne en externe cursussen, maar ook om training on the job, functieroulatie, conferenties, kwaliteitscirkels en zelfstudie. De belangrijkste variabelen waaraan aandacht wordt besteed, zijn:

- organisatiekenmerken (waaronder bedrijfsgrootte);

- technische en organisatorische veranderingen;

- opleiding en training in het algemeen (programma, budget, doelgroepen);

- bedrijfsopleidingen;

- gegevens over interne en externe cursussen (type, omvang, kosten);

- gegevens over bedrijven die geen bedrijfsopleidingen hebben.

Beperking van het onderzoek is dat niet over alle sectoren gegevens worden verzameld. De bedrijfssectoren overheid, gezondheidszorg en landbouw en visserij blijven buiten beschouwing. Bovendien worden alleen bedrijven met meer dan 10 werknemers bij het onderzoek betrokken.

Voor de Employability Monitor biedt het CVTS2 met name interessante gegevens op het gebied van de behoefte aan employability, doordat veel informatie wordt verzameld over technologische en organisatorische ontwikkelingen. Bovendien wordt veel aandacht besteed aan de inspanningen van organisaties op het gebied van opleiding en ontwikkeling. Ook bij het in beeld brengen van de effectueringscondities kan het CVTS2 dus een belangrijke rol gaan spelen. Aangezien CVTS2 op zijn vroegst pas in 2001 bruikbare data oplevert is zij voor de eerste Monitor nog niet bruikbaar. De employability-situatie binnen het midden- en kleinbedrijf kan slechts gedeeltelijk worden bepaald. De kleine ondernemingen blijven immers buiten het onderzoek.

\section{Schoolverlaters Informatie Systeem (ROA)}

Het Researchcentrum voor Onderwijs en Arbeidsmarkt (ROA) is verantwoordelijk voor een aantal enquête-onderzoeken onder schoolverlaters. De enquête Registratie Uitstroom en Bestemming Schoolverlaters (RUBS) is gericht op schoolverlaters van het algemeen voortgezet onderwijs (AVO), het voorbereidend beroepsonderwijs $(\mathrm{V}(\mathrm{M}) \mathrm{BO})$ en de beroepsopleidende (BOL) en beroepsbegeleidende leerwegen $(B B L)$ in het secundair beroepsonderwijs. De enquête wordt uitgevoerd onder aus- 
piciën van het LDC-expertisecentrum voor loopbaanvraagstukken en wordt sinds 1992 landelijk afgenomen.

Met ingang van 1996 is het RUBS onderzoek qua opzet en vraagstelling afgestemd op de HBO-Monitor. De HBO-Monitor is in 1991 ontwikkeld als instrument voor kwaliteitszorg gericht op afgestudeerden van het hoger beroepsonderwijs. Het onderzoek wordt uitgevoerd onder auspiciën van de HBO-Raad. Inmiddels heeft onder auspiciën van de Vereniging van Samenwerkende Universiteiten (VSNU) voor het eerst in 1998 ook een integrale meting plaatsgevonden onder de afgestudeerden van de universiteiten. De coördinatie van deze WO-Monitor berust bij het ROA. De afzonderlijke universiteiten zijn echter verantwoordelijk voor de dataverzameling, die volgens landelijke richtlijnen verloopt.

RUBS, HBO-Monitor en WO-Monitor leveren tezamen de data voor het door ROA ontwikkelde Schoolverlaters Informatie Systeem (SIS). Met de toevoeging van de WO-Monitor is met ingang van 1998 een monitor beschikbaar over de volle breedte van het onderwijs. In het najaar van 1998 zijn ruim 110.000 schoolverlaters benaderd afkomstig uit meer dan 100 onderwijsinstellingen. De totale respons bedroeg 50\%. Dat wil zeggen dat het SIS 1998 over zo'n 55.000 schoolverlaters informatie bevat. Deze informatie heeft vooral betrekking op:

- persoonskenmerken;

- gevolgde opleiding en scholing;

- ervaring opgedaan tijdens studie;

- cursus of bedrijfsopleiding;

- belangrijkste huidige bezigheid;

- werk en beroep;

- aansluiting opleiding en huidige functie;

- mening over gevolgde opleiding achteraf;

- bijscholing.

De schoolverlateronderzoeken hebben elk een dubbele doelstelling. In de eerste plaats fungeren ze als kwaliteitszorginstrument voor individuele onderwijsinstellingen. Daarnaast, en daarin schuilt het belang van de onderzoeken voor de Employability Monitor, hebben de schoolverlateronderzoeken de functie van statistisch betrouwbare, landelijk representatieve databron over de transitie van school naar werk of vervolgonderwijs.

Inmiddels vormen de schoolverlateronderzoeken RUBS, HBO-Monitor en WO-Monitor de belangrijkste en meest gedetailleerde informatiebron over de bestemming van schoolverlaters. Met name de verschillende aspecten van de individuele employability van zowel werkenden als niet-werkenden kunnen aan de hand van de schoolverlateronderzoeken in kaart worden gebracht. De informatie beperkt zich echter tot degenen die circa anderhalf jaar geleden het initieel onderwijs hebben verlaten. Bovendien wordt niet voor elk schooltype exact dezelfde informatie verkregen. In de HBO-Monitor en de WO-Monitor komen meer voor de Employability Monitor interessante variabelen voor dan in RUBS. RUBS, de HBO-Monitor, en de WO-Monitor 
bevatten geen informatie over de omvang van het bedrijf waar de schoolverlater nu werkzaam is. Gegevens toegespitst op het midden- en kleinbedrij kunnen daarom met deze bronnen niet worden verkregen. Intemational Adult Literacy Survey (IALS) en het Intemational Life Skills Survey
(ILSS), OECD

Het International Adult Literacy Survey is opgezet om internationaal vergelijkbare data te verzamelen op het gebied van een aantal competenties van mensen. 13 landen, waaronder Nederland, en drie intergouvernementele organisaties (OECD, de Europese Unie en UNESCO) hebben aan het survey meegewerkt. In het survey is aan grote groepen volwassenen, variërend van 1.500 tot 6.000 per land, een uitvoerige test voorgelegd om hun 'functionele geletterdheid' in beeld te krijgen. Hierbij gaat het om de vaardigheden om schriftelijke informatie te begrijpen en deze adequaat te gebruiken. Daarbij worden drie verschillende aspecten onderscheiden, namelijk:

- Proza; de vaardigheid om kranten- en tijdschriftartikelen en andere verhalen te lezen en er correcte informatie aan te ontlenen;

- Document; de vaardigheid om informatie te begrijpen en te gebruiken uit documenten zoals sollicitatieformulieren, gebruiksaanwijzingen, bijsluiters, kaarten, tabellen en grafieken;

- Kwantitatief; de vaardigheid om rekenkundige bewerkingen toe te passen zoals het invullen van een cheque, het bepalen van de prijs bij het doen van boodschappen, het berekenen van de rente van een lening en dergelijke.

Voor deze drie domeinen van geletterdheid zijn vijf prestatieniveaus onderscheiden. Volwassenen die een score halen op niveau 1 ondervinden de meeste problemen met het begrijpen van en omgaan met alledaagse teksten en rekentaken. Volwassenen op niveau 2 ondervinden minder problemen, maar verkeren als gevolg van de steeds hogere vaardigheidseisen in het werk en het maatschappelijk leven eveneens in de risicosfeer. Vanaf niveau 3 voldoen volwassenen aan de minimumeisen. Niveau 5 duidt zelfs op een zeer hoog niveau van functionele geletterdheid.

Het IALS maakt het mogelijk competentieprofielen te schetsen van groepen mensen in verschillende landen en daartussen dus vergelijkingen te maken. De Nederlandse variant van de IALS wordt afgenomen bij niet geïnstitutionaliseerde ingezetenen van 16 tot en met 74 jaar. Per adres is maximaal éen persoon geïnterviewd, wat uiteindelijk resulteert in een bestand met gegevens van 3.000 respondenten. 2.750 in de leeftijd van 16 tot en met 64 jaar en 250 in de leeftijd van 65 tot en met 74 jaar. Om de representativiteit te waarborgen is vervolgens een weging toegepast op basis van woonplaats, leeftijd, geslacht en opleiding.

Het IALS zal op korte termijn worden voortgezet middels de International Life Skills Survey. Het ILSS test naast taalvaardigheden en rekenvaardigheden ook algemene vaardigheden, zoals probleemoplossend vermogen en teamwork, praktische vaardigheden en ICT-vaardigheden. Voor de monitor zou deelname derhalve bijzonder interessant zijn, omdat een duidelijk beeld wordt verkregen van aanwezige competenties. 
Voor de Employability Monitor biedt het IALS of het ILSS voornamelijk inzicht in de individuele employability en dan met name op het gebied van de competenties van zowel werknemers als niet-werkenden. Het IALS biedt vooralsnog niet de mogelijkheid om verbijzonderingen te maken naar bedrijfsgrootte.

\section{SZW-Werkgeverspanel}

Het SZW-Werkgeverspanel is in opdracht van het Ministerie van Sociale Zaken en Werkgelegenheid in 1998 gestart als vervolg op het in 1995 gestarte ZARA-Werkgeverspanel. Doel van het panel is het relateren van veranderingen in het beleid van werkgevers aan het gevoerde overheidsbeleid. Vanaf 1998 worden gedurende een periode van twee jaar, de bedrijven in het panel driemaal per jaar bevraagd over een aantal onderwerpen. De onderwerpen die aan de orde komen zijn onder andere:

- organisatiekenmerken;

- arbeidsomstandigheden en ziekteverzuim;

- reïntegratie;

- arbeidsongeschiktheid;

- maatregelen van bedrijven die de (toekomstige) arbeidsdeelname van het zittend personeel bevorderen ('employability');

- maatregelen van bedrijven die de arbeidsdeelname van specifieke groepen, zoals langdurig baanlozen, ouderen, allochtonen en vrouwen, beïnvloeden.

De gegevens worden verzameld door middel van interviews met de directeur, de eigenaar of medewerkers van de afdeling personeelszaken bij ongeveer 3.600 bedrijven. Aan de eerste interviewronde van het SZW-Werkgeverspanel namen 3.618 bedrijven deel met in totaal ruim 455.000 werknemers. Om te zorgen dat uit alle bedrijfssectoren en grootteklassen voldoende bedrijven zijn vertegenwoordigd, is per combinatie van grootteklasse en bedrijfssector een steekproef van bedrijven getrokken (gestratificeerd). De bedrijfssectoren overheid en onderwijs zijn daarbij niet opgenomen.

Voor de Employability Monitor biedt het SZW-Werkgeverspanel vooral inzicht in de effectueringscondities die door de werkgever zijn geschapen ter bevordering van de employability van werknemers en niet-werkenden. Met name faciliteiten kunnen met gebruikmaking van het panel goed in beeld worden gebracht. Bovendien is het mogelijk verbijzonderingen te maken naar bedrijfsgrootte.

Inmiddels is door SZW besloten niet met het werkgeverspanel door te gaan. Deze databron is dus niet geschikt voor een periodieke Employability Monitor.

\section{Arbeidsverhoudingen-survey TNO-Arbeid}

In het Arbeidsverhoudingen-survey is vooralsnog eenmalig onderzoek gedaan naar de stand van zaken met betrekking tot personeelsbeleid in Nederland. In het onderzoek, dat heeft plaatsgevonden in 1999 in samenwerking met het Ministerie van Sociale Zaken en Werkgelegenheid, is gebruik gemaakt van een vragenlijst die bij 
1013 Nederlandse organisaties uit de markt- en de overheidssector is afgenomen. Het onderzoek is opgezet in samenwerking met het Ministerie van Sociale Zaken en Werkgelegenheid en wordt verricht in de vorm van computerondersteunde face-toface interviews onder personeelsfunctionarissen. De vragenlijst is opgebouwd uit een aantal verschillende delen. Het eerste deel bevat vragen over de organisatie als geheel, de omgeving van de organisatie, de personeelssamenstelling en de doelstellingen van de organisatie. Daarna komen de verschillende managementvelden aan de orde. Achtereenvolgens zijn dit:

- organisatiekenmerken;

- personeelsplanning;

- werving en selectie;

- primaire en secundaire arbeidsvoorwaarden;

- begeleiding en beoordeling;

- opleidingen;

- loopbanen en mobiliteit;

- ARBO- en verzuimbeleid.

Bij de trekking van de steekproef is ervoor gezorgd dat van alle bedrijfssectoren en grootteklassen voldoende bedrijven vertegenwoordigd zijn. Er is dus sprake van een gestratificeerde steekproef, waarbij uit elke combinatie van grootteklasse en bedrijfssector een steekproef is getrokken, waardoor de resultaten van het onderzoek representatief zijn voor de gehele Nederlandse beroepsbevolking.

Voor de Employability Monitor biedt het TNO-arbeidsverhoudingen-survey met name informatie over effectueringscondities, waarbij gedacht moet worden aan het in beeld brengen van de geboden faciliteiten om employability te verbeteren. De survey kan echter alleen worden gebruikt bij de monitoring van de employability van werknemers en zij is vooralsnog eenmalig. Het is wel mogelijk verbijzonderingen te maken naar bedrijfsgrootte, zij het dat organisaties met minder dan tien werknemers niet tot de onderzoeksgroep behoren. De employability van de werkenden in het midden- en kleinbedrijf kan daardoor slechts gedeeltelijk worden bepaald.

\section{De Arbeidsmarkt naar Opleiding en Beroep (ROA)}

De Arbeidsmarkt naar Opleiding en Beroep is een tweejaarlijkse overzichtsrapportage van het Researchcentrum voor Onderwijs en Arbeidsmarkt (ROA) in het kader van het Project Onderwijs-Arbeidsmarkt (POA). Het POA-project heeft als doel inzicht te verschaffen in de huidige en toekomstige positie van de verschillende beroeps- en opleidingscategorieën en bestrijkt de volledige Nederlandse arbeidsmarkt. De verwachte ontwikkelingen op de middellange termijn staan hierbij centraal. Dat wil zeggen dat prognoses worden opgesteld van de over vijf jaar verwachte situatie op de arbeidsmarkt. Dit is van belang om diegenen, die nu voor een studiekeuze staan, zo goed mogelijk te informeren over de arbeidsmarktperspectieven van de verschillende opleidingen en werkgevers inzicht te bieden in de knelpunten in de personeelsvoorziening waarmee zij zullen worden geconfronteerd. 
Het overzichtsrapport De Arbeidsmarkt naar Opleiding en Beroep richt zich overigens niet zozeer op studiekiezers of werkgevers maar meer op beleidsmatig betrokkenen bij de aansluiting tussen het onderwijs en de arbeidsmarkt, zoals Arbeidsvoorziening, sociale partners, het onderwijsveld en vooral de overheid. Het overzichtsrapport heeft met name een signaalfunctie, die de mogelijkheid biedt te anticiperen op de verwachte ontwikkelingen op de arbeidsmarkt.

Voor de Employability Monitor zijn de prognosestudies van het ROA van belang omdat zij inzicht geven in de verwachte arbeidsmarktontwikkelingen. De prognoses maken immers duidelijk in hoeverre de vraag naar de verschillende beroepen en opleidingen zal toenemen of afnemen. Bovendien kunnen deze prognoses verbijzonderd worden naar bedrijfssector (zie ook ROA, 2000). Verbijzondering naar bedrijfsgrootte is in de huidige opzet van de Arbeidsmarkt naar Opleiding en Beroep niet mogelijk.

\section{Werkzoekendenbestand (Arbeidsvoorziening/CWI)}

Door Arbeidsvoorziening worden administratieve en kwalificerende intakes van werkzoekenden ten behoeve van de bemiddeling naar werk gehouden. Deze beide intakes leveren informatie op omtrent de afstand tot de arbeidsmarkt van werkzoekenden. Op basis van deze intakes en de afstand tot de arbeidsmarkt uitgedrukt in fases wordt de intredekans van werkzoekenden geregistreerd en wordt geadviseerd over individuele trajectvereisten. Om de intakes in heel Nederland op een soortgelijke wijze te laten plaatsvinden is een tweetal instrumenten ontwikkeld; de Kansmeter en de Kwint?.

In combinatie met elkaar leveren de Kansmeter en de Kwint voor de Employability Monitor belangrijke informatie omtrent de employability van niet-werkende werkzoekenden. Het werkzoekendenbestand, zoals Arbeidsvoorziening dit op termijn zou willen inrichten, is een belangrijke databron voor de monitoring van de employability van niet-werkende werkzoekenden. Niet alleen voor de individuele employability van niet-werkende werkzoekenden, maar ook voor de beroepsperspectieven en de effectueringscondities zou het werkzoekendenbestand veel informatie opleveren. Het bestand geeft echter geen informatie over de afstand tot de arbeidsmarkt van de niet-werkenden die zich niet aanbieden op de arbeidsmarkt en is vooralsnog niet landelijk beschikbaar.

\section{CAO-Inventarisatie: (Arbeidsinspectie)}

In 1999 is door de Arbeidsinspectie een onderzoek gedaan naar de mate waarin employability is geïnstitutionaliseerd in CAO's en de manier waarop dat gebeurt. Hierbij is ook gekeken naar de eventuele verschillen die er bestaan tussen bedrijfs-

8. Inmiddels hebben ruim 60 Centra voor Werk en Inkomen (CWI) de basisdienstverlening, waartoe ook de administratieve en kwalificerende intakes behoren, van Arbeidsvoorziening overgenomen. Op termijn zullen ruim 200 van dergelijke CWI's worden ingericht.

9. Zie: appendix A voor een nadere beschrijving van beide instrumenten. 
sectoren. In Nederland worden jaarlijks ongeveer 800 CAO's afgesloten, die circa $85 \%$ van de werkzame beroepsbevolking dekken. Het onderzoek naar employabilityafspraken in CAO's wordt tweemaal per jaar uitgevoerd op een steekproef van 132 grotere CAO's. Naast een inventarisatie van expliciete afspraken over employability is ook geïnventariseerd in welke mate CAO-afspraken voorkomen over een aantal afzonderlijk te onderscheiden instrumenten, die met elkaar een potentieel kunnen vormen voor samenhangend employability-beleid. Deze instrumenten zijn:

- scholing (algemeen of functiegericht);

- sparen voor scholing;

- persoonlijk opleidings-/ontwikkelingsplan (POP);

- bedrijfsopleidings-/ontwikkelingsplan (BOP);

- beoordelings- en functioneringsgesprek;

- motiverend beloningsbeleid.

Het inzicht in de CAO-afspraken op het gebied van employability is voor de Employability Monitor met name van belang om een helder beeld te krijgen van de effectueringscondities voor zover deze betrekking hebben op het institutioneel kader. De CAO-inventarisatie is alleen van betekenis voor het in beeld brengen van de employability van werknemers.

Hoe Zoeken Werkzoekenden (Arbeidsvoorziening)

'Hoe Zoeken Werkzoekenden?' (HZW) is de landelijke arbeidsaanbodmonitor van Arbeidsvoorziening. Het onderzoek bestaat in haar huidige vorm sinds 1992 en heeft tot doel het in kaart brengen van ontwikkelingen in het aanbod van werkzoekenden en de mate waarin werkzoekenden werk weten te vinden. Sinds 1997 loopt parallel aan het HZW het onderzoek 'Hoe Zoeken Ingeschrevenen?'(HZI). In het kader van $\mathrm{HZI}$ wordt in grote lijnen dezelfde vragenlijst voorgelegd aan alleen die personen die ingeschreven staan bij arbeidsbureaus/CWl's of daar recent ingeschreven hebben gestaan.

$\mathrm{HZW}$ is een telefonisch onderzoek dat in opdracht van Arbeidsvoorziening uitgevoerd wordt door het call-centre van Research voor Beleid, een onderzoeksinstituut dat is gespecialiseerd in het verzamelen en bewerken van informatie die nodig is voor de ontwikkeling, uitvoering en evaluatie van beleid. De enquête richt zich op iedereen in Nederland die in het bezit is van een telefoonaansluiting en de steekproeftrekking is aselect. De steekproef bestaat uit ruim 40.000 cases. Vervolgens volgt een screening waarbij wordt nagegaan in hoeverre iemand relevant is voor het onderzoek. Het onderzoek richt zich alleen op diegenen die:

- actief op zoek zijn naar (ander) werk (de werkzoekenden);

- het laatste jaar (ander) werk hebben gevonden (de werkvinders);

- ingeschreven staan bij het arbeidsbureau of het CWI (formeel ingeschrevenen) of daar recent ingeschreven hebben gestaan.

Bovendien gaat het alleen om personen die tussen de 15 en 65 jaar oud zijn. Aan de meting van 1999 is deelgenomen door ongeveer 16.000 respondenten, een respons van slechts $40 \%$. Deze lage respons maakt dat de representativiteit van het onder- 
zoek niet gewaarborgd kan worden. Wel is het mogelijk met redelijke marges bepaalde trends vast te stellen. De verzamelde data worden gewogen op basis van CBS-gegevens over de samenstelling van huishoudens, leeftijd, sekse, regio en verstedelijkingsgraad. Op het moment is nog niet duidelijk of er ook in het jaar 2000 een $\mathrm{HZW}$-onderzoek zal plaatsvinden. De continuïteit is dus niet gewaarborgd

De vragenlijst die de basis vormt voor het $\mathrm{HZW}$ - en $\mathrm{HZI}$-onderzoek is opgebouwd uit 18 blokken, waarin van de diverse onderzoeksgroepen informatie wordt verzameld over onder anderen:

- zoekgedrag;

- scholingsbereidheid;

- inkomen;

- wensberoep;

- werkervaring.

De HZW- en HZl-bestanden zijn vanzelfsprekend alleen interessant voor het in beeld brengen van de employability van niet-werkende werkzoekenden, werkvinders en ingeschrevenen. De gebruiksmogelijkheden liggen daarbij vooral op het terrein van de individuele employability van deze groepen.

\subsection{Inventarisatie naar employability-dimensie}

In de schema's in de figuren 3.1 en 3.2 wordt weergegeven welke databronnen van belang zijn bij het in beeld brengen van bepaalde dimensies van de employability van respectievelijk werknemers en niet-werkenden. In de schema's is te zien welke databron gegevens zou kunnen opleveren voor een bepaalde employability-dimensie.

In figuur 3.1 worden, zoals in hoofdstuk 2 is uiteengezet, vier dimensies onderscheiden bij de monitoring van de employability van werknemers. Hierbij gaat het om:

- individuele employability;

- behoefte aan employability bij organisaties;

- arbeidsmarktontwikkelingen;

- effectueringscondities.

In het schema in figuur 3.1 worden deze vier dimensies verder verbijzonderd naar aspecten, variabelen en subvariabelen. De individuele employability van werknemers kent bijvoorbeeld een viertal aspecten: vermogen, bereidheid, inspanningen en persoonlijke belemmeringen. Deze aspecten van de individuele employability van werknemers worden vervolgens verbijzonderd naar een aantal onderliggende variabelen. Zo wordt bij de employability-'bereidheid' van werknemers een drietal variabelen onderscheiden: mobiliteitsbereidheid, opleidingsbereidheid en bereidheid tot een brede inzet. Enkele van deze variabelen worden weer verbijzonderd naar subvariabelen. De variabele mobiliteitsbereidheid wordt bijvoorbeeld verbijzonderd naar functionele mobiliteitsbereidheid en geografische mobiliteitsbereidheid. De monitoring van de employability van werknemers vereist het verzamelen van data die het mogelijk maken de variabelen en eventueel subvariabelen goed te meten. 
In figuur 3.2 (op pagina 53 en 54) worden voor de niet-werkenden de drie dimensies van het conceptuele model onderscheiden, namelijk:

- individuele employability;

- vraag naar kwalificaties;

- effectueringscondities.

In beide schema's wordt aangegeven of en in hoeverre de onderzochte databronnen geschikte data opleveren om een bepaalde dimensie of een onderliggende variabele te monitoren. Bij een zwart vlak is de databron in principe geschikt om een bepaalde variabele of subvariabele te meten. Is een vlak gevuld met stippen dan dekt de databron de variabele of subvariabele slechts gedeeltelijk af. Bovendien is een aparte vulling gebruikt in gevallen waarin een databron voor een bepaalde (sub)variabele slechts voor een deel van de onderzoekspopulatie informatie bevat.

\subsubsection{Bruikbare databronnen voor de Employability Monitor voor werknemers}

Figuur 3.1 laat zien dat geen enkele databron een volledige dimensie van de employability van werknemers afdekt, met uitzondering van de arbeidsmarktperspectieven, die op basis van het ROA-rapport De arbeidsmarkt naar opleiding en beroep in beeld kunnen worden gebracht.

Per dimensie zal nu worden aangegeven welke databron voor de Employability Monitor gebruikt zal worden en waarom. De criteria die zullen worden gebruikt bij de keuze tussen de verschillende databronnen zijn achtereenvolgens:

- de mate waarin de databron de gehele onderzoekspopulatie dekt;

- steekproefomvang en betrouwbaarheid;

- aantal door databron gemeten (sub)variabelen;

- periodiciteit.

Individuele employability

Het schema in figuur 3.1 maakt duidelijk dat veel van de onderzochte databronnen informatie bevatten over de individuele employability van werknemers. Geen enkele bron geeft echter een volledig beeld, wat tot gevolg heeft dat voor de Employability Monitor voor werknemers gebruik moet worden gemaakt van meerdere databronnen.

Het OSA-Aanbodpanel, de Enquête Beroepsbevolking, het Schoolverlatersinformatiesysteem en het International Adult Literacy Survey zijn in principe de meest interessante databronnen. Omdat het Schoolverlaters Informatie Systeem alleen gegevens bevat over schoolverlaters, is deze databron niet bruikbaar om de individuele employability van alle werknemers in beeld te brengen. De overige drie databronnen hebben wel betrekking op de gehele werkzame bevolking. Omdat de Enquête Beroepsbevolking qua steekproefomvang verreweg het grootst is en de enquête bovendien jaarcijfers oplevert, is deze databron in principe het meest geschikt voor het genereren van indicatoren met betrekking tot de individuele employability van werknemers. 


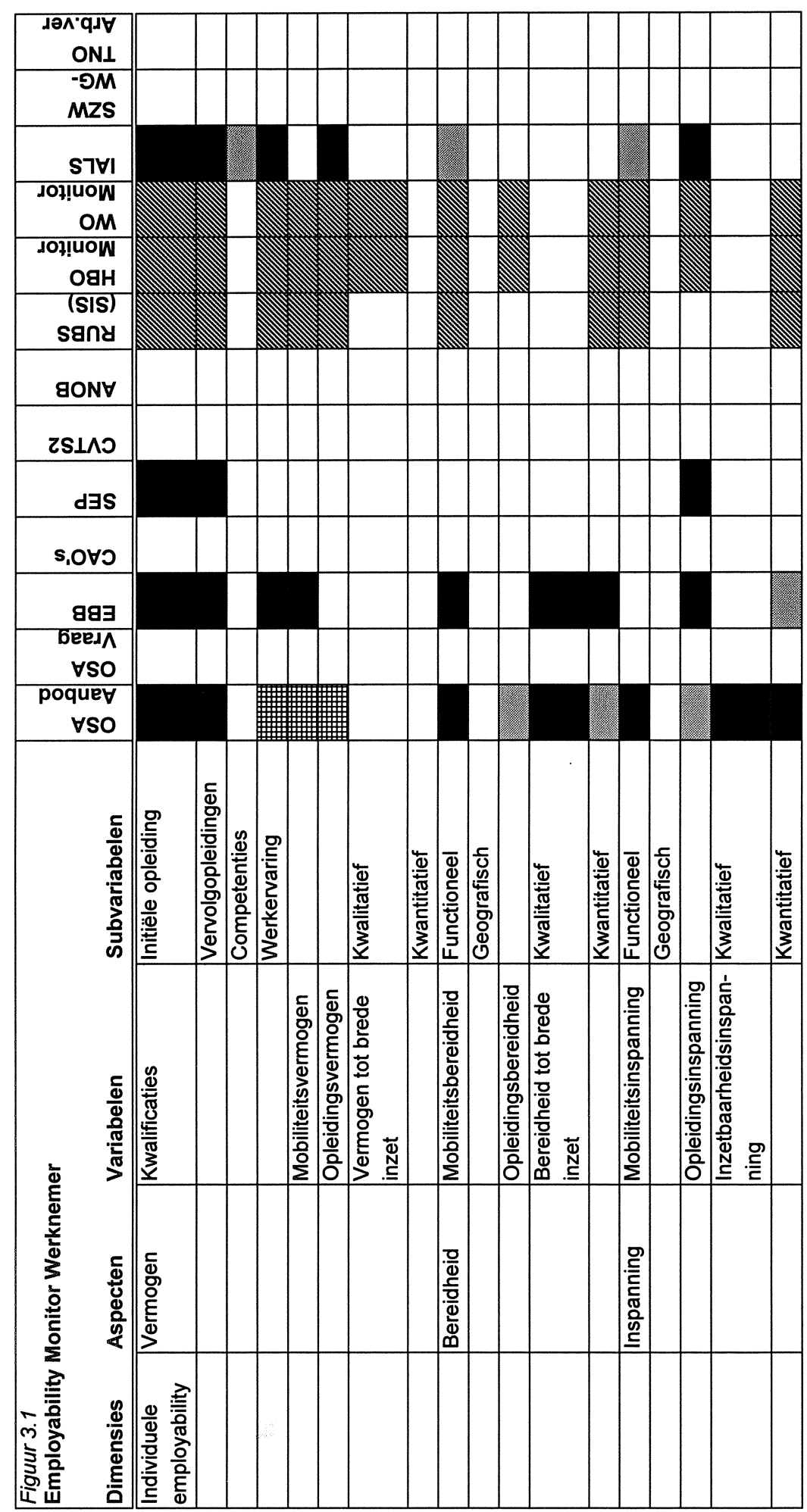




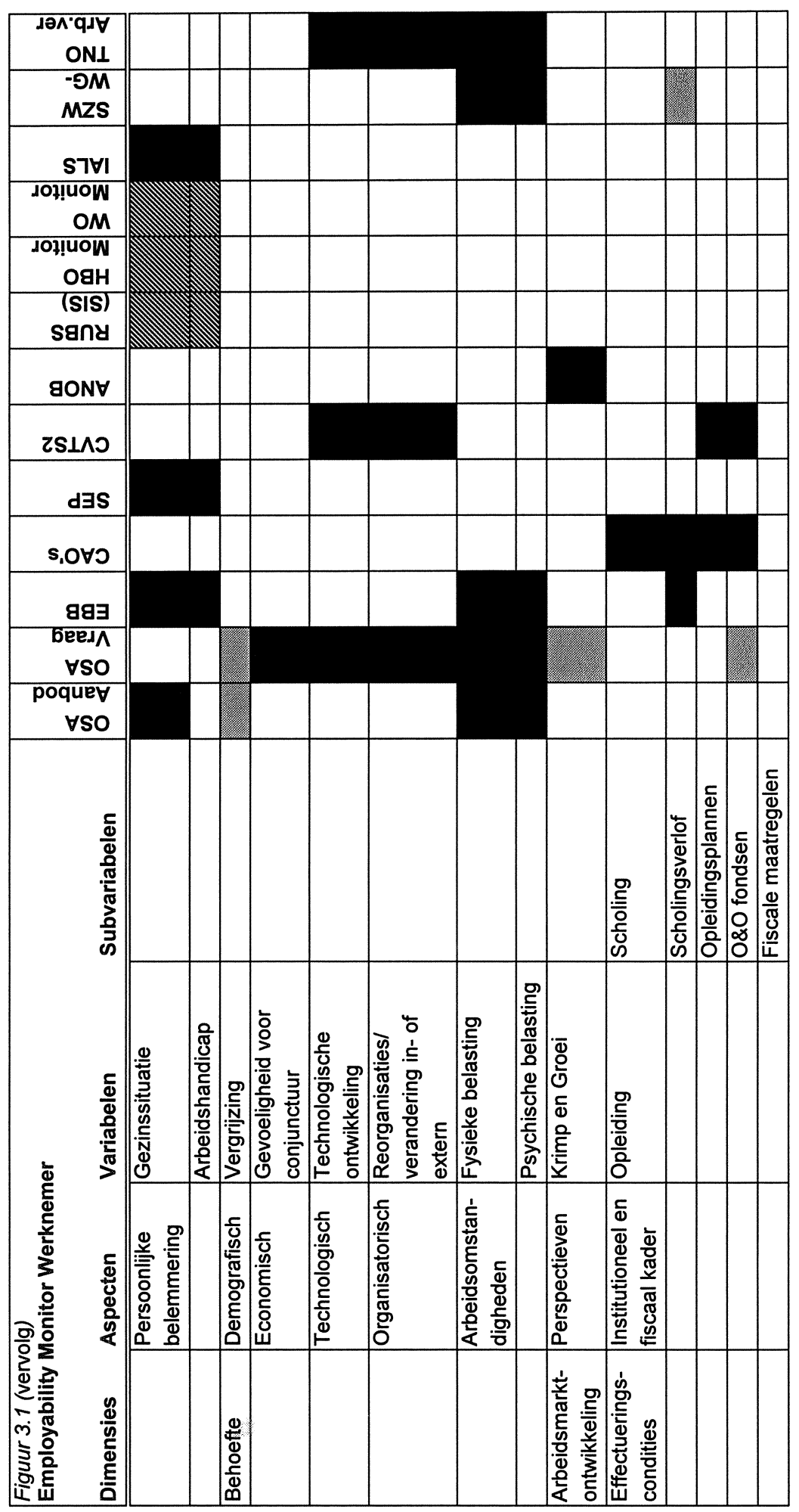




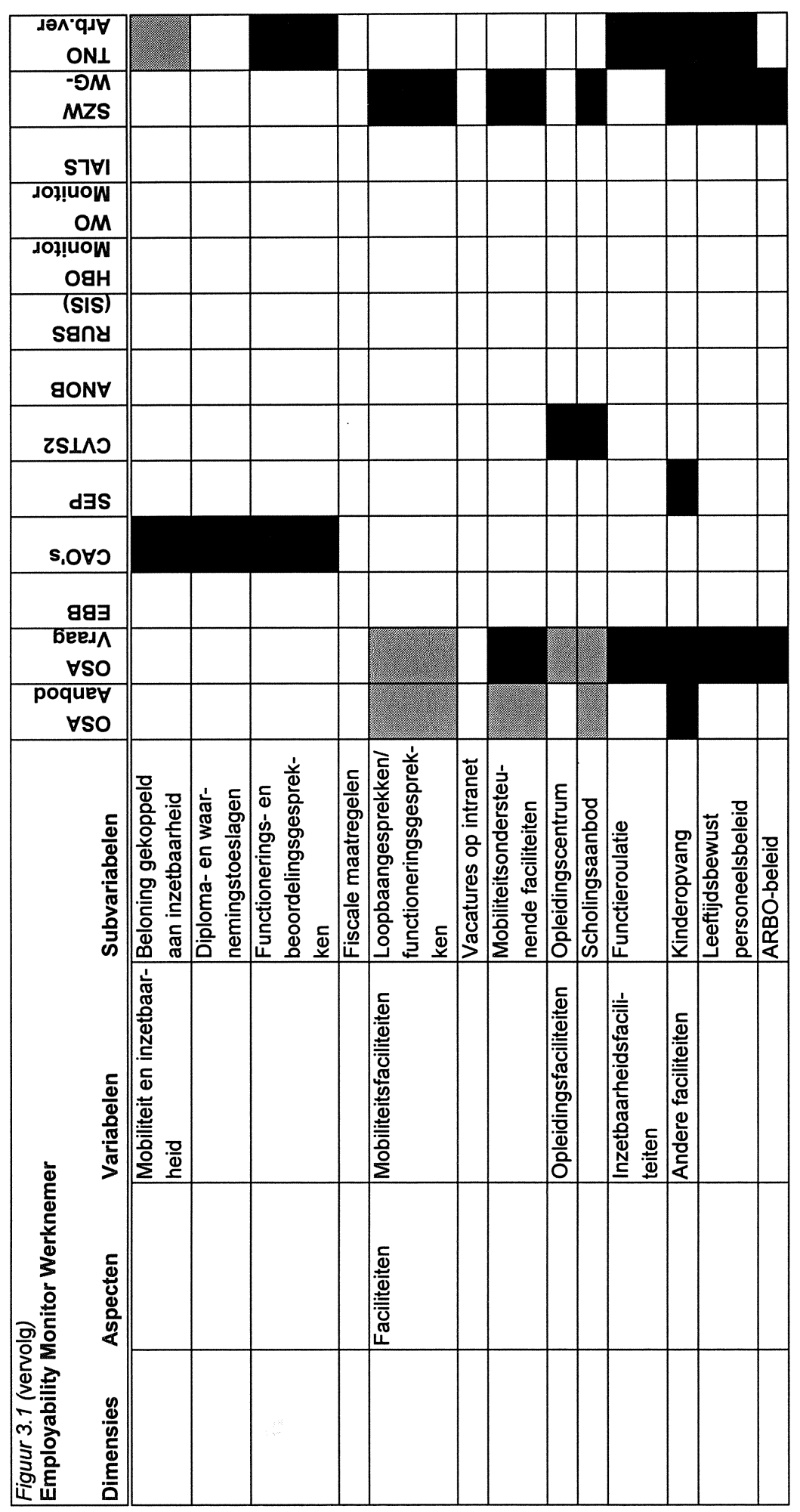




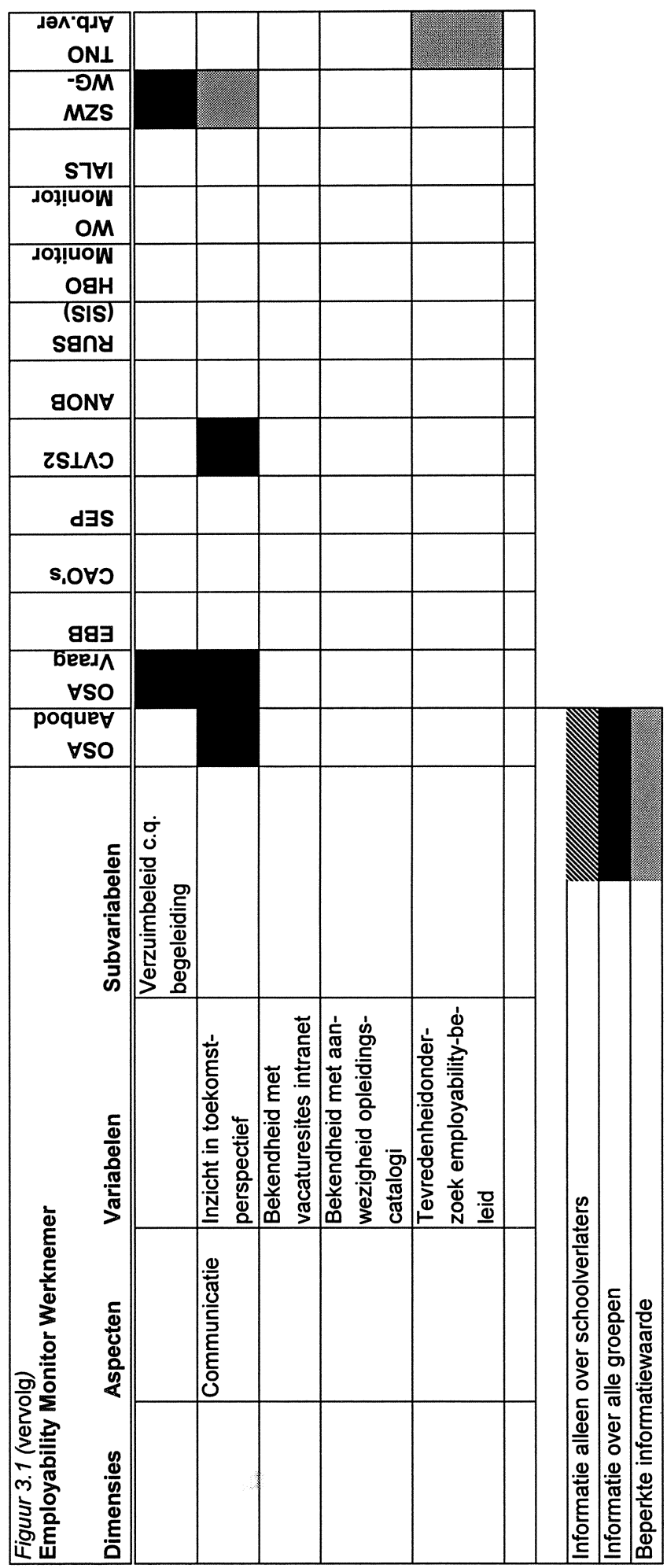


Omdat de EBB op een aantal punten echter geen informatie oplevert, zal daarnaast gebruik gemaakt moeten worden van het OSA-Aanbodpanel en het IALS. Het OSAAanbodpanel levert belangrijke additionele data over bijvoorbeeld de inspanningen van werknemers op het gebied van hun functionele mobiliteit en kwalitatieve en kwantitatieve inzetbaarheid. Het IALS geldt met name als een interessante databron op het gebied van de competenties, een terrein waarop zowel de EBB als het OSAAanbodpanel tekortschieten.

Bij de monitoring van de individuele employability van werknemers geldt dus de Enquête Beroepsbevolking als de primaire bron. Het OSA-Aanbodpanel en het IALS gelden als aanvullende databronnen. Met deze drie databronnen wordt het grootste deel van de variabelen en subvariabelen afgedekt. Een aantal variabelen blijft echter nog ongedekt of wordt onvoldoende gemeten. Hierbij gaat het om geografische mobiliteitsbereidheid. Ook is er slechts een zeer globaal beeld van de competenties waarover de werknemers beschikken. Deze variabelen worden vooralsnog niet of onvoldoende door bestaande instrumenten gemeten.

\section{Behoefte aan employability bij organisaties}

Uit het schema in figuur 3.1 blijkt dat voor het monitoren van de behoefte aan employability die binnen organisaties bestaat meerdere databronnen geschikt zijn. Het OSA-Vraagpanel, de Enquête Beroepsbevolking, het Continuing Vocational Training Survey, het SZW-Werkgeverspanel en het TNO-Arbeidsverhoudingensurvey bevatten op dit punt alle vijf waardevolle informatie. De meest volledige van de vijf databronnen is echter het OSA-Vraagpanel. In dit panel worden vijf van de zes onderscheiden aspecten van employability-behoefte volledig afgedekt. Voor informatie omtrent demografische ontwikkelingen in de zin van vergrijzing en ontgroening, informatie die uit het OSA-Vraagpanel slechts gedeeltelijk kan worden afgeleid, moet aansluiting worden gezocht bij de Enquête Beroepsbevolking. De tweede Continuing Vocational Training Survey is vooralsnog niet gehouden, zodat nog weinig te zeggen is over de respons. Wel biedt dit survey voor de toekomst mogelijk aanvullende informatie. Hetzelfde geldt voor beide andere databronnen; SZW-Werkgeverspanel en TNO-Arbeidsverhoudingensurvey, zij zijn uitermate geschikt als aanvullende databron. Van de eerste van deze twee databronnen is echter bekend dat zij niet wordt voortgezet. Bij de continuilteit van het TNO-Arbeidsverhoudingen-survey worden bovendien vraagtekens geplaatst. Ook zonder het SZW-Werkgeverspanel en TNO-Arbeidsverhoudingensurvey worden echter alle aspecten van de behoefte afgedekt. Van lacunes is dus geen sprake.

\section{Arbeidsmarktperspectieven}

Voor het in beeld brengen van de arbeidsmarktperspectieven en de uitwijkmogelijkheden van werknemers zijn de arbeidsmarktprognoses van het Researchcentrum voor Onderwijs en Arbeidsmarkt geschikt. De tweejaarlijkse overzichtsrapportage de Arbeidsmarkt naar Opleiding en Beroep geeft inzicht in de toekomstige positie van verschillende beroeps- en opleidingscategorieën. De prognoses bestrijken de volledige Nederlandse arbeidsmarkt. Bovendien wordt er informatie gegeven over de 
meest voor de hand liggende uitwijkmogelijkheden voor werknemers. Er is op dit punt geen sprake van enige lacunes in de informatievoorziening.

\section{Effectueringscondities}

Figuur 3.1 laat zien dat ook voor de monitoring van de effectueringscondities meerdere databronnen in meer of mindere mate bruikbaar zijn. Bij de monitoring van het institutioneel en fiscaal kader waarbinnen bedrijfsorganisaties opereren gaat de aandacht met name uit naar de CAO-Inventarisatie van de Arbeidsinspectie. Deze inventarisatie heeft tot doel CAO's te scannen op aanwezigheid van maatregelen die passen binnen het employability ondersteunend beleid. Op het gebied van de fiscale maatregelen is (nog) geen geschikte databron voorhanden.

Voor het in beeld brengen van de faciliteiten die werkgevers werknemers bieden om tot een effectuering van hun employability te komen kan een aantal databronnen worden gebruikt, namelijk: het OSA-Vraagpanel, de Continuing Vocational Training Survey, de TNO-Arbeidsverhoudingensurvey en het SZW-Werkgeverspanel. Het OSA-Vraagpanel biedt de meeste mogelijkheden, maar is op een aantal punten onvolledig. Deze onvolledigheid kan worden opgevangen door naast het OSA-Vraagpanel ook de Continuing Vocational Training Survey en het SZW-Werkgeverspanel te gebruiken. De laatstgenoemde databron bevat bijvoorbeeld gegevens over loopbaangesprekken, gegevens waar het OSA-Vraagpanel niet in voorziet. Bovendien vult het SZW-Werkgeverspanel lacunes op op het gebied van informatie over scholingsaanbod. Dit panel gaat evenwel verdwijnen en is dus geen structurele databron. Het TNO-Arbeidsverhoudingensurvey zou hieraan nog informatie kunnen toevoegen. Vooralsnog is dit echter slechts een eenmalig onderzoek.

Informatie over de verschillende communicatievariabelen is niet beschikbaar. De enige variabele die door een of meerdere databronnen wordt afgedekt is het inzicht in eigen toekomstperspectief. Het OSA-Aanbodpanel biedt de beste mogelijkheden om in deze informatie te voorzien.

\subsubsection{Bruikbare databronnen voor de Employability Monitor voor niet-wer- kenden}

Figuur 3.2 laat zien welke databronnen de meest interessante gegevens leveren voor de Employability Monitor voor de niet-werkenden. In het schema valt allereerst op dat er belangrijke verschillen bestaan tussen de bruikbare databronnen voor de nietwerkende werkzoekenden en andere groepen niet-werkenden. In de meeste databronnen worden aan degenen die werk zoeken meestal andere vragen gesteld dan aan degenen die geen werk zoeken. Bij de beschrijving van de bruikbare databronnen zullen beide categorieën niet-werkenden apart moeten worden bekeken. Bij het bepalen van de meest bruikbare databron bij de monitoring van de employability van niet-werkenden zal ook worden uitgegaan van de vier eerder genoemde criteria, te weten:

- de mate waarin de databron de gehele onderzoekspopulatie dekt;

- steekproefomvang en betrouwbaarheid; 
- aantal door databron gemeten (sub)variabelen;

- periodiciteit.

De mate waarin een databron voldoet aan deze criteria bepaalt de bruikbaarheid van de desbetreffende databron.

Individuele employability

Om de individuele employability van niet-werkenden in beeld te brengen ligt een zestal databronnen in eerste instantie voor de hand; het OSA-Aanbodpanel, het Werkzoekendenbestand, de Enquête Beroepsbevolking, het Schoolverlatersinformatiesysteem, het 'Hoe zoeken Werkzoekenden' bestand en de Intermational Adult Literacy Survey. Alleen de Enquête Beroepsbevolking, het 'Hoe zoeken Werkzoekenden'-bestand en de Intemational Adult Literacy Survey zijn in beginsel bruikbaar om de individuele employability van groepen niet-werkenden te monitoren. In het OSAAanbodpanel wordt, als gevolg van de routing die in de vragenlijst wordt gehanteerd, een aantal vragen die informatie over de individuele employability opleveren slechts aan niet-werkende werkzoekenden gesteld. Andere vragen, die niet minder interessant zijn voor de monitor, worden weer alleen aan respondenten gesteld die niet werken en bovendien geen werk zoeken; de niet-participerenden (zie figuur 3.2). Het Werkzoekendenbestand bevat alleen informatie over de individuele employability van de niet-werkende werkzoekenden die ingeschreven zijn bij Arbeidsvoorziening. Andere groepen niet-werkenden komen bij deze databronnen dus helemaal niet aan de orde. In het Schoolverlatersinformatiesysteem ten slotte wordt alleen informatie verzameld over schoolverlaters, die niet langer dan anderhalf jaar geleden hun initiële opleiding hebben afgerond. Deze databron levert dus alleen informatie over niet-werkenden, die net van school af komen.

Vanwege het grote verschil in steekproefomvang tussen de EBB (90.000 personen) en de IALS (3.000) is duidelijk dat de eerste de meest bruikbare informatie oplevert voor de monitoring van de individuele employability van niet-werkenden. Bovendien wordt de EBB jaarlijks afgenomen. Het HZW heeft met een steekproef van 40.000 cases en een respons van 16.000 echter een belangrijke rol als aanvullende bron bij het monitoren van de individuele employability van niet-werkenden. Evenals bij de werknemers kan de IALS als aanvullende databron worden gebruikt om de competenties waarover men beschikt te indiceren. IALS, HZW en EBB hebben echter een aantal belangrijke lacunes voor wat betreft het bepalen van de individuele employability van niet-werkenden. Deze lacunes bevinden zich o.a. op het gebied van het mobiliteitsvermogen, geografische mobiliteitsinspanningen en de kwantitatieve inzetbaarheidsinspanning. 


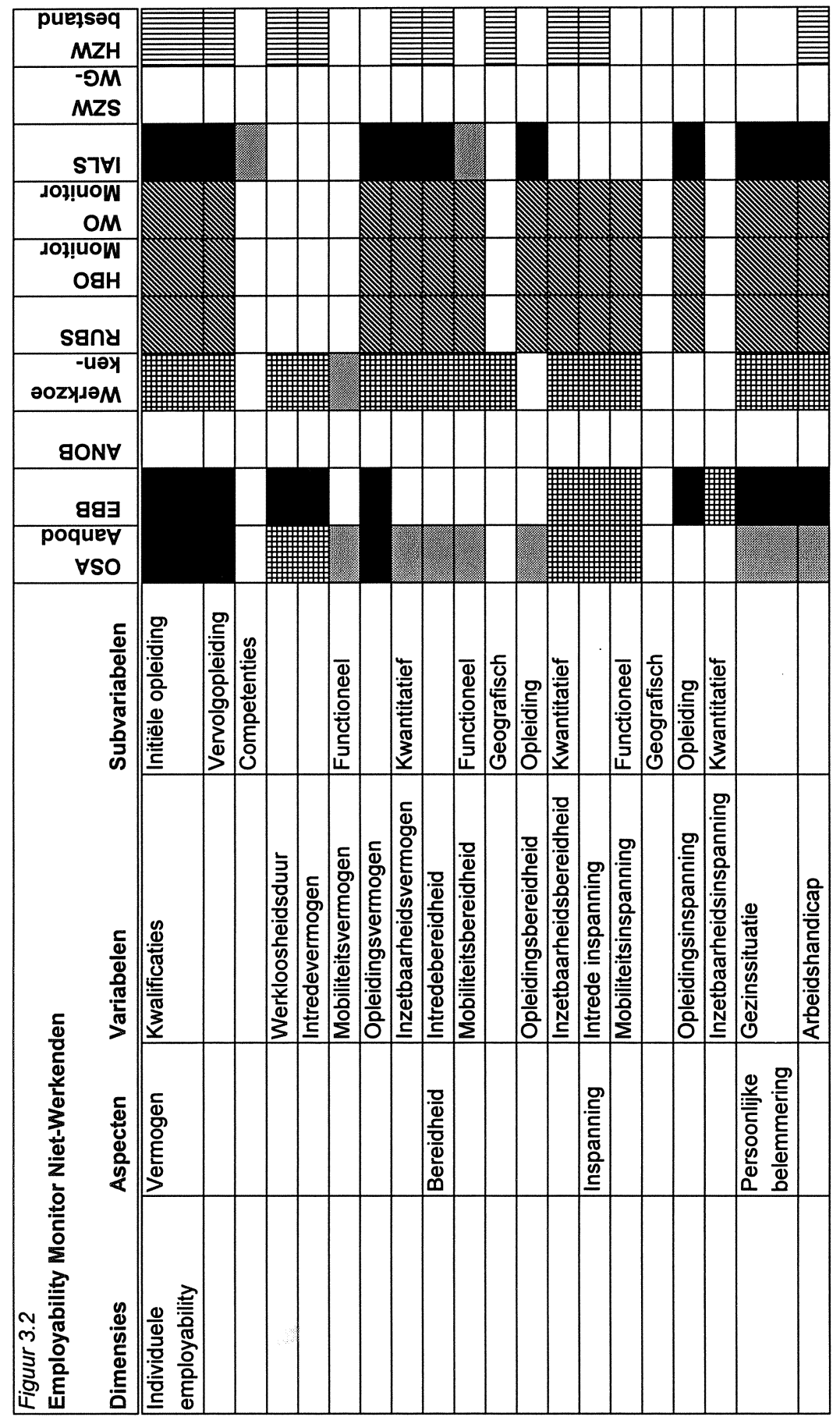




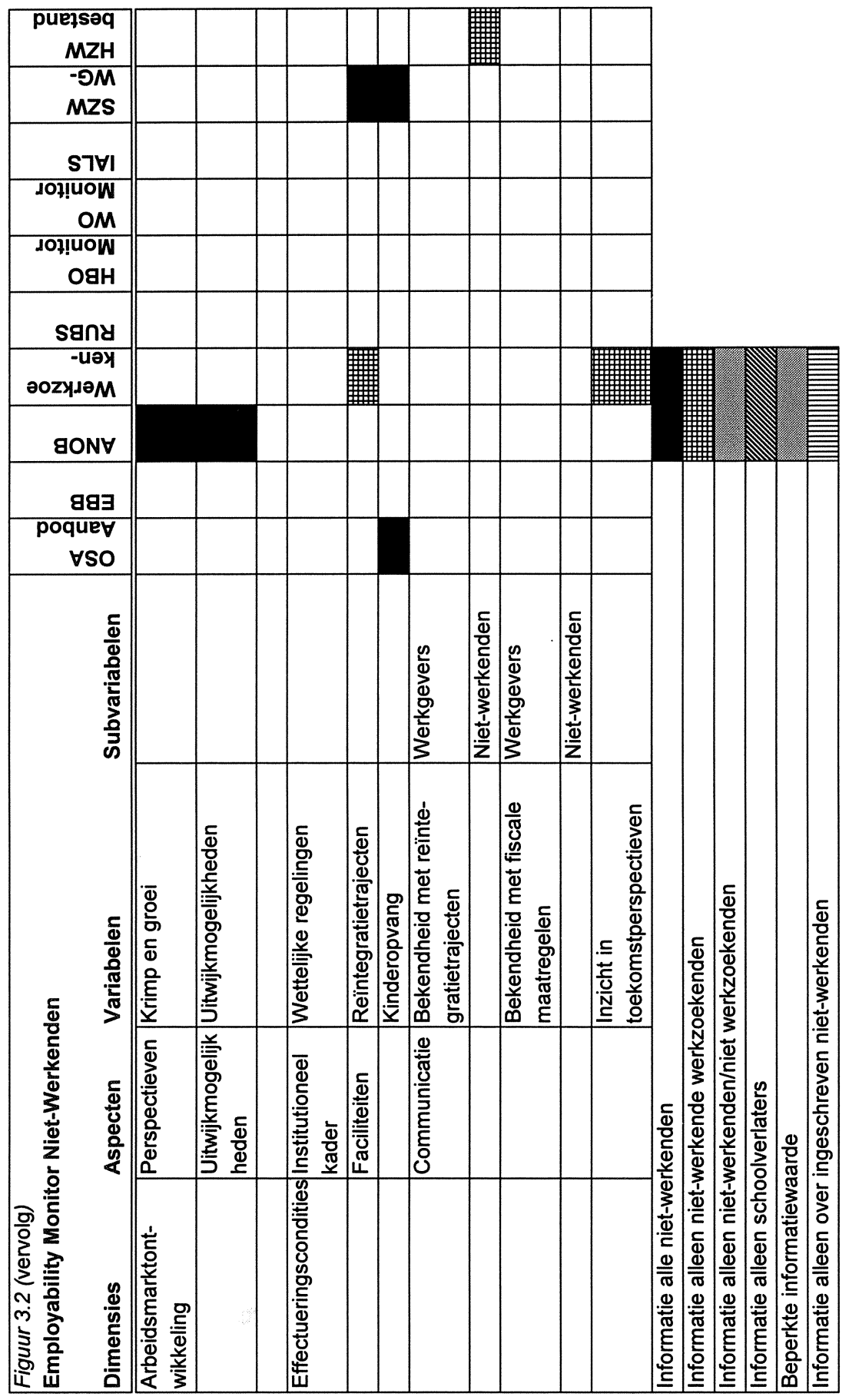


Voor de niet-werkende werkzoekenden kan het Werkzoekendenbestand van Arbeidsvoorziening (CWI) deels in deze informatiebehoefte voorzien, omdat dit bestand juist met dat doel wordt onderhouden. De individuele employability van nietwerkende werkzoekenden zou dus beter in beeld kunnen worden gebracht door gebruik te maken van de gegevens die met behulp van de Kansmeter en de Kwint in het Werkzoekendenbestand worden verzameld. In dat geval zou alleen de individuele employability van de andere groepen niet-werkenden op basis van de Enquête Beroepsbevolking worden gemonitord. Omdat Kansmeter noch Kwint vooralsnog een landelijke dataset hebben opgeleverd is het Werkzoekendenbestand nog niet te gebruiken en ligt het gebruik van de EBB en het HZW voor niet-werkende werkzoekenden meer voor de hand.

\section{Arbeidsmarktontwikkeling}

Omdat het er bij niet-werkenden om gaat hen zo snel mogelijk aan een baan te helpen is in feite slechts een beeld van de actuele arbeidsmarktsituatie nodig. Prognoses van de arbeidsmarktsituatie op middellange termijn zijn voor het bepalen van de intredekans van niet-werkenden immers niet direct van belang. Binnen het Researchcentrum voor Onderwijs en Arbeidsmarkt is inmiddels een prognose-instrument ontwikkeld dat de korte termijn arbeidsmarktontwikkelingen naar opleiding en beroep in beeld brengt. In deze prognoses wordt één jaar vooruit gekeken. Voor het in beeld brengen van de intredekans van niet-werkenden zijn deze korte termijnprognoses uiteraard zeer geschikt. Bovendien kunnen op basis van de beschikbare ROA-informatie de uitwijkmogelijkheden worden bepaald, zodat ook een beeld kan worden verkregen van de mogelijke intredeberoepen van niet-werkenden.

\section{Effectueringscondities}

Bij het in kaart brengen van de effectueringscondities voor de niet-werkenden is er sprake van een aantal belangrijke lacunes. Met name gegevens over de fiscale kaers en communicatie zijn momenteel niet voorhanden. Wat betreft de faciliteiten is de beschikbare informatie bovendien zeer summier. De enige bruikbare databronnen voor wat betreft de effectueringscondities zijn het OSA-Aanbodpanel, waarin informatie over kinderopvang wordt verzameld, het Werkzoekendenbestand, dat indirect inzicht geeft in de beschikbare reïntegratietrajecten voor groepen niet-werkende werkzoekenden en het SZW-Werkgeverspanel, waarin informatie over kinderopvang en reïntegratietrajecten wordt verzameld. De meest bruikbare van deze drie is waarschijnlijk het OSA-Aanbodpanel, aangezien het SZW-Werkgeverspanel niet meer wordt voortgezet en het Werkzoekendenbestand enkel op werkzoekenden gericht is en vooralsnog geen bruikbare dataset heeft opgeleverd. 


\section{Een eerste invulling van de Employability Monitor: werknemers}

In de voorgaande hoofdstukken is ingegaan op de manier waarop de Employability Monitor het best vorm gegeven zou kunnen worden en welke databronnen daarbij het meest bruikbaar zouden zijn. In dit hoofdstuk wordt met gebruikmaking van de op dit moment beschikbare data een eerste invulling gegeven aan de monitor zoals die wordt voorgesteld. Tevens zal in dit hoofdstuk wat dieper worden ingegaan op de indicatoren die zijn gebruikt voor het in beeld brengen van de verschillende variabelen en subvariabelen. Daarbij wordt telkens aangegeven in hoeverre de gebruikte indicatoren een adequate maatstaf vormen en waar mogelijk een andere vraagstelling of een andere indicator betere informatie zou kunnen leveren. In dit hoofdstuk wordt de Employability Monitor voor werknemers gepresenteerd. Hierbij komen achtereenvolgens de individuele employability (4.1), de behoefte aan employability (4.2), de arbeidsmarktperspectieven (4.3) en de effectueringscondities (4.4) aan de orde. In hoofdstuk 5 zal een eerste invulling van de Employability Monitor voor nietwerkenden worden besproken.

\subsection{Individuele employability van werknemers}

De individuele employability van werknemers kan vooralsnog het beste in beeld worden gebracht door gebruik te maken van de Enquête Beroepsbevolking van het CBS. Lacunes die zijn aangetroffen kunnen op dit moment grotendeels worden opgevangen door naast de EBB ook het OSA-Aanbodpanel en de Intemational Adult Literacy Survey te gebruiken. Hierbij geldt als kanttekening dat de informatie uit de IALS in 1993 is verzameld. Deze data zijn dus niet erg recent.

\section{Vermogen}

Om de vermogens van werknemers in beeld te brengen wordt allereerst in kaart gebracht wat de kwalificaties zijn van individuele werknemers. Kwalificaties worden gemeten aan de hand van een drietal indicatoren. Allereerst wordt gekeken naar de initiële opleiding en eventuele vervolgopleidingen. Hierbij is zowel het niveau als de richting van de opleiding in principe van belang. Omdat in de EBB bij het bepalen van 'de hoogst genoten (afgeronde) opleiding' zowel wordt gekeken naar de initiële opleiding als naar de vervolgopleidingen, wordt bij deze eerste invulling van de monitor alleen gekeken naar de hoogst genoten afgeronde opleiding van een werknemer. Hierbij wordt het opleidingsniveau als uitgangspunt genomen, omdat een verdere verbijzondering naar opleidingsrichting de opgenomen tabel onnodig complex en onleesbaar zou maken. In een statistische bijlage of tabellenboek zou een dergelijke tabel eventueel wel opgenomen kunnen worden.

De tweede indicator van het kwalificatieniveau van werknemers is het competentieniveau. Hierbij worden in eerste instantie alleen de lees-, schrijf-, spreek- en rekenvaardigheid van werknemers in beeld gebracht. Behalve opleidingsniveau is ook het competentieniveau van belang omdat het opleidingsniveau van werknemers nog nauwelijks iets zegt over de rekenvaardigheid of schrijfvaardigheid, terwijl inzicht in 
de aanwezigheid van dergelijke vaardigheden wel degelijk van belang is bij het bepalen van iemands individuele employability.

Ten slotte wordt als indicator de werkervaring van werknemers gebruikt. Veel werkervaring betekent immers doorgaans dat werknemers in de loop der tijd veel competenties 'on-the-job' hebben verworven.

Het employability-vermogen van werknemers is echter van meer afhankelijk dan van alleen de genoten opleiding, de aanwezige competenties en de opgebouwde werkervaring. Ook bepaalde sleutelvaardigheden zijn bij het bepalen van het employabilityvermogen van belang. Hierbij worden het mobiliteitsvermogen, het opleidingsvermogen en het vermogen tot een brede inzet onderscheiden. Deze drie vermogens worden overigens wel voor een groot deel bepaald door de genoten opleiding, aanwezige competenties en opgebouwde werkervaring.

Aan de hand van het mobiliteitsvermogen wordt bepaald in hoeverre voor bepaalde werknemers de kans bestaat dat zij een geconcentreerde ervaringsopbouw hebben omdat zij al relatief lang in dezelfde functie bij dezelfde werkgever werkzaam zijn. Een geconcentreerde ervaringsopbouw beperkt de inzetbaarheidsradius van werknemers, wat hen minder employable maakt (zie ook: Thijssen, 1997). De breedte van de opgebouwde werkervaring bepaalt dus het mobiliteitsvermogen van werknemers.

Het opleidingsvermogen is op te vatten als de mate waarin werknemers op grond van hun opleidingshistorie in staat moeten worden geacht een opleiding succesvol af te ronden. De mate waarin werknemers in staat zijn zich te laten scholen is vanzelfsprekend medebepalend voor hun mogelijkheden om actief te blijven op de arbeidsmarkt (zie ook: Wong, 1989).

Het vermogen tot een brede inzet heeft betrekking op de inzetbaarheid van werknemers qua werkuren. Met de opkomst van de 24-uurs economie is het voor een werkgever niet alleen van groot belang dat werknemers zoveel mogelijk verschillende taken op zich kunnen nemen en zich verschillende vaardigheden eigen kunnen maken, maar ook dat zij in staat zijn op wisselende tijden te werken en niet alleen maar van negen tot vijf. Wanneer een werknemer met onregelmatige werktijden kan omgaan en hij bovendien in staat is overuren te maken dan vergroot dat zijn kansen om actief te blijven op de arbeidsmarkt.

Kwalificaties: Initiële en vervolgopleiding

Om een beeld te krijgen van het gemiddelde opleidingsniveau van werkenden ${ }^{10}$ in de verschillende bedrijfssectoren is als indicator de hoogst genoten opleiding gebruikt. De gegevens die hier worden gebruikt komen uit de EBB. In tabel 4.1 is in de laatste kolom weergegeven welk percentage van de werkenden in een bedrijfssector een 'startkwalificatie' heeft voor de arbeidsmarkt, dat wil zeggen een opleiding op MBO

10. Bij de groep werkenden behoren behalve de werknemers in loondienst ook de zelfstandigen. 
niveau of hoger. We noemen deze groep 'voldoende opgeleid'. Overigens past hierbij de kanttekening dat voor sommige sectoren (bijvoorbeeld tuinbouw) voor een deel van de werkenden een lagere opleiding dan MBO al volstaat. Niettemin is het met het oog op de employability van werknemers en mogelijkheden van intersectorale mobiliteit van belang te bezien in hoeverre men een startkwalificatie op MBO-niveau of hoger heeft.

Tabel 4.1

Opleidingsniveau van werkenden per bedrijfssector

\begin{tabular}{|c|c|c|c|c|c|c|}
\hline Bedrijfssector & $\begin{array}{c}\text { Basisonderwijs } \\
\%\end{array}$ & $\begin{array}{c}\mathrm{V}(\mathrm{M}) \mathrm{BO} \\
\%\end{array}$ & $\begin{array}{l}\text { MBO } \\
\%\end{array}$ & $\begin{array}{l}\text { HBO } \\
\%\end{array}$ & $\begin{array}{l}\text { Wo } \\
\%\end{array}$ & $\begin{array}{c}\text { Voldoende } \\
\text { Opgeleid } \\
\%\end{array}$ \\
\hline $\begin{array}{l}\text { Landbouw en visserij } \\
\text { Tuinbouw } \\
\text { Veehouderij } \\
\text { Akkerbouw, bosbouw en visserij }\end{array}$ & $\begin{array}{r}12 \\
16 \\
9 \\
11\end{array}$ & $\begin{array}{l}35 \\
39 \\
32 \\
33\end{array}$ & $\begin{array}{l}49 \\
39 \\
54 \\
51\end{array}$ & $\begin{array}{l}4 \\
4 \\
4 \\
-\end{array}$ & $\begin{array}{l}1 \\
- \\
-\end{array}$ & $\begin{array}{l}54 \\
44 \\
59 \\
56\end{array}$ \\
\hline $\begin{array}{l}\text { Voeding } \\
\text { Vlees- en visverwerking } \\
\text { Overige voedingsproducten } \\
\text { Drank en tabaksproducten }\end{array}$ & $\begin{array}{l}14 \\
23 \\
12\end{array}$ & $\begin{array}{l}28 \\
33 \\
27 \\
21\end{array}$ & $\begin{array}{l}44 \\
37 \\
47 \\
44\end{array}$ & $\begin{array}{r}10 \\
- \\
11 \\
15\end{array}$ & $\begin{array}{l}3 \\
- \\
3 \\
-\end{array}$ & $\begin{array}{l}58 \\
44 \\
60 \\
68\end{array}$ \\
\hline $\begin{array}{l}\text { Chemie } \\
\text { Basischemie } \\
\text { Eindproducten chemie } \\
\text { Kunststofverwerking }\end{array}$ & $\begin{array}{r}9 \\
- \\
7 \\
17\end{array}$ & $\begin{array}{l}23 \\
15 \\
22 \\
34\end{array}$ & $\begin{array}{l}46 \\
55 \\
42 \\
41\end{array}$ & $\begin{array}{r}15 \\
17 \\
18 \\
8\end{array}$ & $\begin{array}{r}8 \\
9 \\
11 \\
-\end{array}$ & $\begin{array}{l}68 \\
80 \\
71 \\
50\end{array}$ \\
\hline $\begin{array}{l}\text { Metaal- en elektrotechniek } \\
\text { Basismetaal } \\
\text { Metaalproducten } \\
\text { Machine-industrie } \\
\text { Elektrotechniek } \\
\text { Transportmiddelen }\end{array}$ & $\begin{array}{r}8 \\
13 \\
10 \\
4 \\
8 \\
11\end{array}$ & $\begin{array}{l}27 \\
21 \\
34 \\
24 \\
22 \\
31\end{array}$ & $\begin{array}{l}46 \\
49 \\
48 \\
52 \\
40 \\
44\end{array}$ & $\begin{array}{r}13 \\
10 \\
7 \\
15 \\
20 \\
10\end{array}$ & $\begin{array}{r}5 \\
- \\
- \\
4 \\
10 \\
-\end{array}$ & $\begin{array}{l}64 \\
65 \\
56 \\
71 \\
70 \\
58\end{array}$ \\
\hline $\begin{array}{l}\text { Overige industrie } \\
\text { Textiel } \\
\text { Hout- en bouwmaterialen } \\
\text { Papier } \\
\text { Grafische industrie }\end{array}$ & $\begin{array}{r}14 \\
17 \\
23 \\
10 \\
5\end{array}$ & $\begin{array}{l}27 \\
30 \\
34 \\
30 \\
20\end{array}$ & $\begin{array}{l}44 \\
43 \\
36 \\
45 \\
53\end{array}$ & $\begin{array}{r}11 \\
8 \\
6 \\
13 \\
15\end{array}$ & $\begin{array}{l}4 \\
- \\
- \\
7\end{array}$ & $\begin{array}{l}59 \\
53 \\
43 \\
60 \\
75\end{array}$ \\
\hline Energie & 5 & 15 & 54 & 18 & 7 & 80 \\
\hline $\begin{array}{l}\text { Bouw en onroerend goed } \\
\text { Bouw } \\
\text { Exploitatie van onroerend goed }\end{array}$ & $\begin{array}{r}9 \\
12 \\
-\end{array}$ & $\begin{array}{l}29 \\
32 \\
15\end{array}$ & $\begin{array}{l}51 \\
49 \\
55\end{array}$ & $\begin{array}{r}8 \\
5 \\
18\end{array}$ & $\begin{array}{l}2 \\
1 \\
9\end{array}$ & $\begin{array}{l}62 \\
55 \\
82\end{array}$ \\
\hline Handel en reparatie & 8 & 28 & 52 & 9 & 2 & 64 \\
\hline $\begin{array}{l}\text { Transport en communicatie } \\
\text { Scheeps- en luchtvaart } \\
\text { Weg- en railvervoer } \\
\text { Communicatie }\end{array}$ & $\begin{array}{r}11 \\
6 \\
13 \\
9\end{array}$ & $\begin{array}{l}31 \\
15 \\
34 \\
29\end{array}$ & $\begin{array}{l}43 \\
44 \\
43 \\
42\end{array}$ & $\begin{array}{r}11 \\
28 \\
7 \\
14\end{array}$ & $\begin{array}{l}4 \\
6 \\
3 \\
5\end{array}$ & $\begin{array}{l}58 \\
78 \\
52 \\
61\end{array}$ \\
\hline $\begin{array}{l}\text { Bank- en verzekeringswezen } \\
\text { Bankwezen } \\
\text { Verzekeringswezen }\end{array}$ & $\begin{array}{l}1 \\
2 \\
-\end{array}$ & $\begin{array}{l}13 \\
13 \\
13\end{array}$ & $\begin{array}{l}\mathbf{5 3} \\
50 \\
57\end{array}$ & $\begin{array}{l}20 \\
21 \\
19\end{array}$ & $\begin{array}{l}12 \\
14 \\
10\end{array}$ & $\begin{array}{l}85 \\
85 \\
85\end{array}$ \\
\hline
\end{tabular}


Tabel 4.1 (vervolg)

Opleidingsniveau van werkenden per bedrijfssector

\begin{tabular}{|c|c|c|c|c|c|c|}
\hline Bedrijfssector & $\begin{array}{c}\text { 3asisonderwijs } \\
\qquad \%\end{array}$ & $\begin{array}{l}\mathrm{V}(\mathrm{M}) \mathrm{BO} \\
\%\end{array}$ & $\begin{array}{l}\text { MBO } \\
\%\end{array}$ & $\begin{array}{l}\text { HBO } \\
\%\end{array}$ & $\begin{array}{l}\text { Wo } \\
\%\end{array}$ & $\begin{array}{c}\text { Voldoende } \\
\text { Opgeleid } \\
\%\end{array}$ \\
\hline $\begin{array}{l}\text { Horeca en zakelijke dienstverlening } \\
\text { Horeca } \\
\text { Zakelijke dienstverlening } \\
\text { Overige commerciële dienstverlening }\end{array}$ & $\begin{array}{r}8 \\
13 \\
6 \\
9\end{array}$ & $\begin{array}{l}18 \\
31 \\
14 \\
21\end{array}$ & $\begin{array}{l}41 \\
47 \\
37 \\
51\end{array}$ & $\begin{array}{r}21 \\
8 \\
26 \\
14\end{array}$ & $\begin{array}{r}13 \\
- \\
18 \\
4\end{array}$ & $\begin{array}{l}74 \\
57 \\
80 \\
70\end{array}$ \\
\hline $\begin{array}{l}\text { Kwartaire diensten } \\
\text { Gezondheidszorg } \\
\text { Overige kwartaire diensten }\end{array}$ & $\begin{array}{l}4 \\
4 \\
3\end{array}$ & $\begin{array}{l}11 \\
11 \\
12\end{array}$ & $\begin{array}{l}46 \\
49 \\
29\end{array}$ & $\begin{array}{l}25 \\
24 \\
30\end{array}$ & $\begin{array}{l}14 \\
12 \\
27\end{array}$ & $\begin{array}{l}85 \\
85 \\
85\end{array}$ \\
\hline $\begin{array}{l}\text { Overheid en onderwijs } \\
\text { Onderwijs } \\
\text { Overheid }\end{array}$ & $\begin{array}{l}2 \\
2 \\
3\end{array}$ & $\begin{array}{r}10 \\
5 \\
14\end{array}$ & $\begin{array}{l}33 \\
14 \\
48\end{array}$ & $\begin{array}{l}36 \\
55 \\
21\end{array}$ & $\begin{array}{l}18 \\
24 \\
14\end{array}$ & $\begin{array}{l}87 \\
93 \\
83\end{array}$ \\
\hline Totaal & 7 & 21 & 45 & 18 & 9 & 72 \\
\hline
\end{tabular}

Bron: CBS/ROA

Kwalificaties: Competenties

Competenties van werknemers worden bepaald aan de hand van gegevens uit het IALS. In dit survey wordt bij respondenten, zoals in hoofdstuk 3 werd aangegeven een test gedaan op drie terreinen, namelijk:

- Kennis en vaardigheden nodig om geschreven informatie te begrijpen, zoals krantenartikelen (prose literacy);

- Kennis en vaardigheden nodig om informatie te lokaliseren en gebruiken, zoals grafieken, tabellen, en kaarten (document literacy);

- Kennis en vaardigheden op rekenkundig gebied, nodig om wiskunde toe te kunen passen (quantitative literacy).

De test maakt het mogelijk werknemers in te delen in een viertal niveaus. Werknemers die niveau 1 scoren hebben onvoldoende competenties om bijvoorbeeld op basis van het opschrift op de verpakking van medicijnen de juiste dosis te bepalen. Deze werknemers zijn het minst competent. Werknemers met een score op niveau 2 zijn weliswaar in staat in het dagelijkse leven goed te functioneren, maar het aanleren van nieuwe vaardigheden levert problemen op. Niveau 3 betekent dat werknemers voldoen aan de minimumeisen, wat wil zeggen dat werknemers goed kunnen functioneren in het dagelijks leven en in staat zijn nieuwe vaardigheden aan te leren. Niveau $4 / 5$ betekent dat werknemers bovendien complexere problemen goed aankunnen.

In de tabellen 4.2 tot en met 4.4 wordt per bedrijfssector het percentage werknemers weergegeven dat op de verschillende competenties een score op niveau 1, 2, 3 of $4 / 5$ heeft. In de laatste kolom van deze tabellen is het percentage werknemers vermeld dat niveau 3 of hoger scoort. Deze werknemers zijn voldoende competent. 
Tabel 4.2

Competentie van werknemers om geschreven informatie te begrijpen, naar bedrijfssector, 1994

\begin{tabular}{|c|c|c|c|c|c|}
\hline Bedrijfssector & $\begin{array}{c}\text { Niveau } \\
1 \\
\%\end{array}$ & $\begin{array}{c}\text { Niveau } \\
2 \\
\%\end{array}$ & $\begin{array}{c}\text { Niveau } \\
3 \\
\%\end{array}$ & $\begin{array}{c}\text { Niveau } \\
4 / 5 \\
\%\end{array}$ & $\begin{array}{c}\text { Voldoende } \\
\text { Competent } \\
\%\end{array}$ \\
\hline $\begin{array}{l}\text { Landbouw en visserij } \\
\text { Industrie en energie } \\
\text { Bouw } \\
\text { Handel } \\
\text { Transport, opslag en communicatie } \\
\text { Zakelijke en financiële dienstverlening }\end{array}$ & $\begin{array}{r}14 \\
8 \\
11 \\
8 \\
5\end{array}$ & $\begin{array}{l}33 \\
32 \\
40 \\
34 \\
34\end{array}$ & $\begin{array}{l}44 \\
48 \\
42 \\
46 \\
42\end{array}$ & $\begin{array}{r}9 \\
13 \\
7 \\
12 \\
19\end{array}$ & $\begin{array}{l}53 \\
61 \\
48 \\
58 \\
61\end{array}$ \\
\hline $\begin{array}{l}\text { en onroerend goed } \\
\text { Overheid, onderwijs en kwartaire diensten }\end{array}$ & $\begin{array}{l}3 \\
4\end{array}$ & $\begin{array}{l}18 \\
16\end{array}$ & $\begin{array}{l}51 \\
54\end{array}$ & $\begin{array}{l}27 \\
27\end{array}$ & $\begin{array}{l}78 \\
80\end{array}$ \\
\hline Totaal & 6 & 25 & 50 & 20 & 69 \\
\hline
\end{tabular}

Bron: OECD/ROA

Tabel 4.3

Competentie om informatie te lokaliseren en gebruiken van werknemers naar bedrijfssector, 1994

\begin{tabular}{|c|c|c|c|c|c|}
\hline Bedrijfssector & $\begin{array}{c}\text { Niveau } \\
1 \\
\%\end{array}$ & $\begin{array}{c}\text { Niveau } \\
2 \\
\%\end{array}$ & $\begin{array}{c}\text { Niveau } \\
3 \\
\%\end{array}$ & $\begin{array}{c}\text { Niveau } \\
4 / 5 \\
\%\end{array}$ & $\begin{array}{c}\text { Voldoende } \\
\text { Competent } \\
\%\end{array}$ \\
\hline \multirow{2}{*}{$\begin{array}{l}\text { Landbouw en visserij } \\
\text { Industrie en energie } \\
\text { Bouw } \\
\text { Handel } \\
\text { Transport, opslag en communicatie } \\
\text { Zakelijke en financiële dienstverlening } \\
\text { en onroerend goed } \\
\text { Overheid, onderwijs en kwartaire diensten }\end{array}$} & $\begin{array}{r}9 \\
5 \\
11 \\
6 \\
4\end{array}$ & $\begin{array}{l}21 \\
28 \\
32 \\
26 \\
25\end{array}$ & $\begin{array}{l}54 \\
45 \\
45 \\
51 \\
42\end{array}$ & $\begin{array}{l}16 \\
22 \\
12 \\
18 \\
28\end{array}$ & $\begin{array}{l}70 \\
67 \\
57 \\
68 \\
71\end{array}$ \\
\hline & $\begin{array}{l}4 \\
4\end{array}$ & $\begin{array}{l}13 \\
19\end{array}$ & $\begin{array}{l}49 \\
50\end{array}$ & $\begin{array}{l}34 \\
28\end{array}$ & $\begin{array}{l}83 \\
77\end{array}$ \\
\hline Totaal & 5 & 22 & 49 & 25 & 73 \\
\hline
\end{tabular}

Bron: OECD/ROA

Tabel 4.4

Competentie om wiskunde toe te passen, naar bedrijfssector, 1994

\begin{tabular}{|c|c|c|c|c|c|}
\hline Bedrijfssector & $\begin{array}{c}\text { Niveau } \\
1 \\
\%\end{array}$ & $\begin{array}{c}\text { Niveau } \\
2 \\
\%\end{array}$ & $\begin{array}{c}\text { Niveau } \\
3 \\
\%\end{array}$ & $\begin{array}{c}\text { Niveau } \\
4 / 5 \\
\%\end{array}$ & $\begin{array}{c}\text { Voldoende } \\
\text { Competent } \\
\%\end{array}$ \\
\hline $\begin{array}{l}\text { Landbouw en visserij } \\
\text { Industrie en energie } \\
\text { Bouw } \\
\text { Handel } \\
\text { Transport, opslag en communicatie } \\
\text { Zakelijke en financiële dienstverlening }\end{array}$ & $\begin{array}{r}9 \\
5 \\
11 \\
6 \\
4\end{array}$ & $\begin{array}{l}21 \\
22 \\
27 \\
27 \\
19\end{array}$ & $\begin{array}{l}49 \\
52 \\
52 \\
49 \\
50\end{array}$ & $\begin{array}{l}21 \\
21 \\
10 \\
19 \\
27\end{array}$ & $\begin{array}{l}70 \\
73 \\
62 \\
67 \\
77\end{array}$ \\
\hline $\begin{array}{l}\text { en onroerend goed } \\
\text { Overheid, onderwijs en kwartaire diensten }\end{array}$ & $\begin{array}{l}5 \\
4\end{array}$ & $\begin{array}{l}13 \\
19\end{array}$ & $\begin{array}{l}42 \\
48\end{array}$ & $\begin{array}{l}40 \\
29\end{array}$ & $\begin{array}{l}82 \\
77\end{array}$ \\
\hline Totaal & 5 & 21 & 48 & 26 & 74 \\
\hline
\end{tabular}


Tabel 4.5 geeft ten slotte per bedrijfssector het percentage werknemers dat op elke van de drie competenties minimaal niveau 3 scoort. Zij worden over het geheel genomen voldoende competent genoemd.

Tabel 4.5

Percentage werknemers dat voldoende competent is, naar bedrijfssector, 1994

\begin{tabular}{lc}
\hline Bedrijfssector & $\%$ \\
\hline & \\
\hline Landbouw en visserij & 53 \\
Industrie en energie & 56 \\
Bouw & 43 \\
Handel & 53 \\
Transport, opslag en communicatie & 54 \\
Zakelijke en financiële dienstverlening en onroerend goed & 74 \\
Overheid, onderwijs en kwartaire diensten & 68 \\
Totaal & 62 \\
\hline
\end{tabular}

Bron: OECD/ROA

De betekenis van de kwalificaties van werknemers voor hun individuele employability wordt daarmee echter nog onvoldoende gemeten. In hoofdstuk 1 bleek al dat er in het buitenland specifiek onderzoek plaatsvindt om competenties zo volledig mogelijk in beeld te brengen. Hierbij wordt het Britse Skills Survey met name genoemd als belangrijke inspiratiebron (zie ook Appendix $A$ ). Dit Survey meet niet alleen de hierboven genoemde competenties, maar gaat ook uitvoerig in op andere voor de employability van mensen essentiële 'key-skills' als:

- communicatieve vaardigheden;

- ICT-skills;

- probleemoplossend vermogen;

- teamwork;

- leervaardigheid.

Het meten van deze sleutelcompetenties is voor het bepalen van het employabilityvermogen van werknemers cruciaal en het verdient dan ook aanbeveling een instrument te ontwikkelen om deze competenties te meten.

\section{Kwalificaties: Werkervaring}

Werkervaring wordt bepaald aan de hand van het totaal aantal jaren dat een werknemer actief is op de arbeidsmarkt. Als databron zou idealiter het EBB gebruikt moeten worden. Hierin wordt gevraagd naar het aantal jaren dat een werkende actief is op de arbeidsmarkt. Omdat de data voor deze eerste opzet niet beschikbaar zijn, is echter gebruik gemaakt van het OSA-Aanbodpanel, waarin dezelfde vraag het uitgangspunt vormt. In tabel 4.6 is per bedrijfssector aangegeven hoeveel jaren werkervaring een werknemer in de desbetreffende sector gemiddeld heeft. 
Tabel 4.6

Aantal jaren dat een werknemer gemiddeld actief is op de arbeidsmarkt, naar bedrijfssector, 1998

Bedrijfssector

Aantal Jaren

Landbouw en visserij

16,4

Tuinbouw

Veehouderij

$16, \overline{4}$

Akkerbouw, bosbouw en visserij

Voeding

16,9

Vlees- en visbewerking

13,1

Overige voedingsproducten

15,3

Drank- en tabaksproducten

Chemie

22,3

Basischemie

22,5

Eindproducten chemie

Kunststofverwerking

Metaal en elektrotechniek

18,5

Basismetaal

17,3

Metaalproducten

18,3

Machine-industrie

20,4

Electrotechniek

Transportmiddelen

Overige industrie

Textiel

Hout- en bouwmaterialen

20,6

Papier

17,7

21,7

Grafische industrie

Energie

Bouw en onroerend goed

Bouw

18,5

Exploitatie van onroerend goed

Handel en reparatie

Transport en communicatie

Scheeps- en luchtvaart

20,6
24,2

Weg- en railvervoer

19,7

Communicatie

21,7

Bank- en verzekeringswezen

Bankwezen

Verzekeringswezen

Horeca en zakelijk dienstverlening

Horeca

16,8

Zakelijke dienstverlening

15,2

Overige commerciële dienstverlening

Kwartaire diensten

Gezondheidszorg

16,9

Overige kwartaire diensten 
Tabel 4.6 (vervolg)

Aantal jaren dat een werknemer gemiddeld actief is op de arbeidsmarkt, naar bedrijfssector, 1998

Bedrijfssector

Aantal Jaren

Overheid en onderwijs

21,8

Onderwijs

21,8

Overheid

Totaal

18,8

Bron: OSA

Mobiliteitsvermogen

Het mobiliteitsvermogen van werknemers wordt bepaald aan de hand van het aantal jaren dat een werknemer werkzaam is in de huidige functie bij de huidige werkgever. Hoe langer een werknemer in dezelfde functie bij dezelfde werkgever werkt, des te sterker de 'ervaringsconcentratie'. Een zeer geconcentreerde ervaring duidt erop dat een werknemer het risico loopt minder gemakkelijk van functie te kunnen veranderen. De cijfers die gebruikt worden bij het in beeld brengen van het mobiliteitsvermogen zijn afkomstig uit het OSA-Aanbodpanel. In tabel 4.7 wordt per bedrijfssector het percentage werknemers vermeld dat korter in de huidige functie bij de huidige werkgever in dienst is, dan de gemiddelde werknemer ${ }^{11}$.

Tabel 4.7

Mobiliteitsvermogen: het percentage werknemers, dat niet te kampen heeft met ervaringsconcentratie, naar bedrijfssector, 1998

Bedrijfssector

Voldoende Mobiliteitsvermogen

$\%$

Landbouw en visserij

83

Tuinbouw

$-$

Veehouderij

83

Akkerbouw, bosbouw en visserij

Voeding

68

Vlees- en visbewerking

69

Overige voedingsproducten $\quad 73$

Drank en tabaksproducten $\quad 50$

Chemie

68

Basischemie

67

Eindproducten chemie

Kunststofverwerking

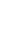

9

11. Het gaat hierbij om de verblijfsduur in de huidige functie bij de huidige werkgever van de
gemiddelde werknemer over alle 35 bedrijfsklassen. Deze bedraagt 7 jaar en 11 maanden. 64 
Tabel 4.7 (vervolg)

Mobiliteitsvermogen: het percentage werknemers, dat niet te kampen heeft met ervaringsconcentratie, naar bedrijfssector, 1998

Bedrijfssector Voldoende Mobiliteitsvermoge

$\%$

Metaal en elektrotechniek

60

Basismetaal

Metaalproducten

53

Machine-industrie

51

Elektrotechniek

61

Transportmiddelen

Overige industrie $\quad 57$

Textiel $\quad 50$

Hout- en bouwmaterialen $\quad 54$

Papier 56

Grafische industrie $\quad 65$

$\begin{array}{ll}\text { Energie } & 48\end{array}$

Bouw en onroerend goed $\quad 66$

Bouw $\quad 67$

Exploitatie van onroerend goed 64

Handel en reparatie $\quad 66$

Transport en communicatie $\quad 57$

Scheeps- en luchtvaart 38

Weg-en railvervoer $\quad 61$

Communicatie $\quad 51$

$\begin{array}{ll}\text { Bank- en verzekeringswezen } & 67\end{array}$

Bankwezen $\quad 67$

Verzekeringswezen 66

Horeca en zakelijke dienstverlening $\quad 78$

$\begin{array}{ll}\text { Horeca } & 84\end{array}$

Zakelijke dienstverlening $\quad 80$

$\begin{array}{ll}\text { Overige commerciële dienstverlening } & 61\end{array}$

Kwartaire diensten $\quad 62$

\begin{tabular}{ll} 
Gezondheidszorg & 62 \\
\hline
\end{tabular}

Overige kwartaire diensten $\quad 63$

Overheid en onderwijs $\quad 50$

Onderwijs

$\begin{array}{ll}\text { Overheid } & 59\end{array}$

$\begin{array}{ll}\text { Totaal } & 62\end{array}$

Bron:OSA/ROA

Opleidingsvermogen

Opleidingsvermogen kan worden bepaald aan de hand van het aantal jaren dat een werknemer in het verleden succesvol scholing heeft gevolgd. Hoe hoger iemands opleidingsniveau, des te groter iemands opleidingsvermogen. In feite wordt het oplei- 
dingsvermogen dus al in belangrijke mate geïndiceerd door het opleidingsniveau van de werkenden per bedrijfssector, zoals dat in tabel 4.1 is gepresenteerd.

\section{Vermogen tot brede kwantitatieve inzet}

Het vermogen tot een brede kwantitatieve inzetbaarheid van werknemers kan het beste worden bepaald aan de hand van gegevens over een tweetal uitingsvormen van kwantitatieve inzetbaarheid, namelijk:

- De mate waarin werknemers in staat zijn overuren te maken.

- De mate waarin werknemers in staat zijn op onregelmatige tijden te werken.

Vooralsnog is deze specifieke informatie echter in bestaande databronnen niet voorhanden. Het OSA-Aanbodpanel biedt echter interessante mogelijkheden voor de toekomst, omdat in de vragenlijst reeds gevraagd wordt of werknemers te maken krijgen met onregelmatige werktijden, ploegen- en wisseldienst, zaterdagwerk en zondagwerk. Bovendien zijn vragen opgenomen over het aantal gemaakte overuren. De vragen die nu gesteld worden meten echter alleen gepleegde inspanningen en niet zozeer de mate waarin een werknemer in staat is om deze inspanningen te leveren.

\section{Het vermogen tot brede kwalitatieve inzet}

Het vermogen tot brede kwalitatieve inzet kan worden bepaald door te kijken in hoeverre een werknemer in staat is zich in te zetten op een ander functiegebied of op een andere afdeling. Idealiter zou derhalve aan werknemers de vraag moeten worden gesteld of deze denkt andere dan de huidige werkzaamheden naar behoren te kunnen verrichten. De mate waarin werknemers zichzelf in staat achten dit te doen bepaalt dan hun kwalitatieve inzetbaarheidsvermogen. Mogelijk zou deze vraag ook aan direct leidinggevenden gesteld moeten worden om een zo realistisch mogelijk beeld te krijgen.

De databronnen die tot nu toe zijn gescand op bruikbare variabelen bevatten dergelijke gegevens echter niet, waardoor in deze eerste invulling van de Employability Monitor afgezien wordt van het in beeld brengen van het vermogen tot een brede kwalitatieve inzetbaarheid van werknemers.

\section{Bereidheid}

Net als bij het employability-vermogen van werknemers wordt ook bij het bepalen van de employability-bereidheid van werknemers een drietal variabelen onderscheiden, te weten: mobiliteitsbereidheid, opleidingsbereidheid en bereidheid tot brede inzet. Bij de mobiliteitsbereidheid wordt een onderscheid gemaakt tussen de functionele mobiliteitsbereidheid en de geografische mobiliteitsbereidheid. De bereidheid tot een brede inzet wordt verbijzonderd naar kwantitatieve inzetbaarheid (aantal uren) en kwalitatieve inzetbaarheid (taken buiten de functie). Primaire databron bij het in beeld brengen van de diverse uitingsvormen van employability-bereidheid is het OSA-Aanbodpanel. Allereerst wordt gekeken naar de functionele mobiliteitsbereidheid van werknemers. 
Functionele mobiliteitsbereidheid kan worden bepaald aan de hand van gegevens over het zoekgedrag van werknemers naar een andere functie. Hierbij wordt gekeken naar het sollicitatiegedrag van werknemers in de afgelopen twaalf maanden. Daarbij is het van wezenlijk belang te weten waarom een werknemer naar een andere baan heeft gezocht, omdat gedwongen zoekgedrag, doordat bijvoorbeeld een functie verdwijnt, geen uiting is van mobiliteitsbereidheid. Over dergelijke motieven wordt in het OSA-Aanbodpanel wel doorgevraagd. Dit in tegenstelling tot de EBB.

De overwegingen, die in het OSA-Aanbodpanel aan de orde komen en die duiden op vrijwillig zoekgedrag en dus functionele mobiliteitsbereidheid zijn:

- beter betaald willen krijgen;

- beter vooruit willen komen;

- werk hebben dat niet bevalt;

- meer zekerheid willen.

In tabel 4.8 wordt het percentage werknemers weergegeven dat aangeeft op grond van een van deze vier overwegingen en dus uit eigen beweging in de afgelopen twaalf maanden actief te hebben gezocht naar een andere baan.

De hier gebruikte maatstaf heeft als nadeel dat de functionele mobiliteitsbereidheid wordt afgeleid uit het feitelijke zoekgedrag. Het zou beter zijn direct in kaart te brengen of een werknemer bereid zou zijn van functie te veranderen als zich daartoe de mogelijkheid voordoet. Misschien kan een dergelijke vraagstelling bij een volgende golf van het OSA-Aanbodpanel worden meegenomen.

Tabel 4.8

Functionele mobiliteitsbereidheid van werknemers, naar bedrijfssector, 1998

Voeding

Vlees- en visbewerking

Overige voedingsproducten

Drank en tabaksproducten

Chemie 
Tabel 4.8 (vervolg)

Functionele mobiliteitsbereidheid van werknemers, naar bedrijfssector, 1998

Bedrijfssector

Voldoende Mobiliteitsbereid

$\%$

Metaal en elektrotechniek

Basismetaal

Metaalproducten

Machine-industrie

Elektrotechniek

10
6

Transportmiddelen

11

11

Overige industrie

12

Textiel

Hout- en bouwmaterialen

Papier

Grafische industrie

13

19

Energie

Bouw en onroerend goed

Bouw

Exploitatie van onroerend goed

Handel en reparatie

Transport en communicatie

Scheeps- en luchtvaart

Weg- en railvervoer

Communicatie

Bank- en verzekeringswezen

Bankwezen

Verzekeringswezen

Horeca en zakelijke dienstverlening 19

Horeca 28

Zakelijke dienstverlening $\quad 19$

$\begin{array}{ll}\text { Overige commerciële dienstverlening } & 14\end{array}$

$\begin{array}{ll}\text { Kwartaire diensten } & 10\end{array}$

Gezondheidszorg 10

Overige kwartaire diensten 13

Overheid en onderwijs $\quad 7$

Onderwijs $r 5$

Overheid

$\begin{array}{ll}\text { Totaal } & 12\end{array}$

Bron: OSA/ROA

Geografische mobiliteitsbereidheid

Om de geografische mobiliteitsbereidheid in beeld te brengen zou moeten worden gevraagd of en in hoeverre een werknemer bereid is te verhuizen voor een nieuwe functie en over welke afstand men bereid is te reizen voor het werk. In geen van de voor werknemers geschikte databronnen komt een dergelijke vraag terug, zodat in 68 
deze eerste opzet van de Employability Monitor de geografische mobiliteitsbereidheid niet in beeld kan worden gebracht.

\section{Opleidingsbereidheid}

Opleidingsbereidheid kan worden bepaald door te vragen in hoeverre een werknemer bereid is zich te laten scholen. Deze specifieke vraagstelling wordt niet teruggevonden in de onderzochte databronnen. Om de opleidingsbereidheid in beeld te brengen wordt daarom voorlopig gebruik gemaakt van het aantal in het recente verleden gevolgde opleidingen en cursussen. Heeft een werknemer in het recente verleden veel opleidingen en cursussen gevolgd, dan is dat een uiting van de bereidheid om opleidingen te volgen. Of er sprake is van een diploma is daarbij niet van belang. In tabel 4.9 wordt in de laatste kolom het percentage werknemers vermeld dat meer dan een gemiddeld ${ }^{12}$ aantal opleidingen per jaar heeft gevolgd in de periode 1996-1998. Deze werknemers kunnen worden beschouwd als werknemers die opleidingsbereid zijn en dus op dit punt voldoende employable. De gegevens die worden gebruikt zijn afkomstig uit het OSA-Aanbodpanel, waarin wordt gevraagd of werkenden in de periode 1996-1998 opleidingen of cursussen hebben gevolgd en hoeveel opleidingen/cursussen zij in die periode hebben gevolgd.

Tabel 4.9

Opleidingsbereidheid naar bedrijfssector, 1996-1998

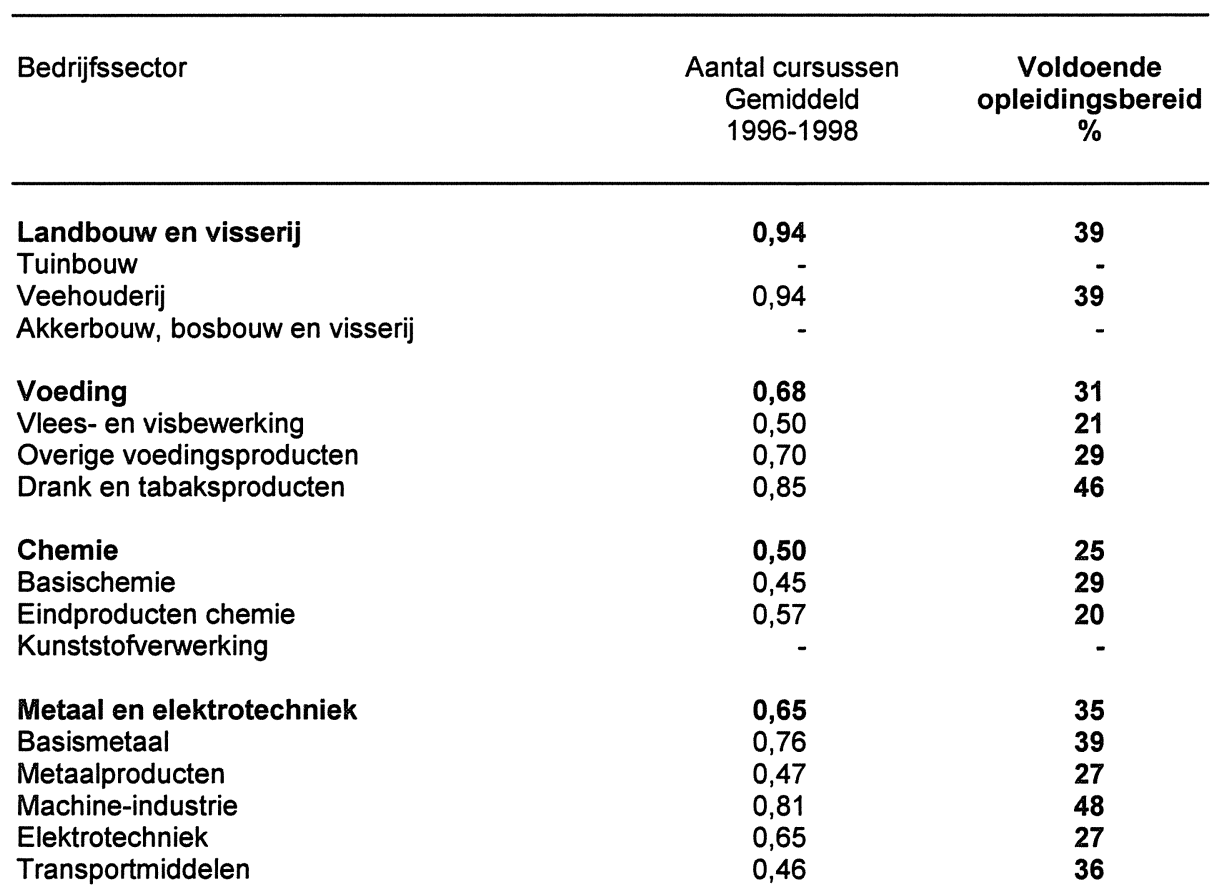

12. Het gemiddelde is het gemiddelde aantal opleidingen dat een werknemer per jaar volgt in de periode 1996-1998 berekend over 35 bedrijfssectoren. Dit bedraagt 0,62 cursussen per jaar. 
Tabel 4.9 (vervolg)

Opleidingsbereidheid naar bedrijfssector, 19ऽ6-1998

\begin{tabular}{|c|c|c|}
\hline Bedrijfssector & $\begin{array}{l}\text { Aantal cursussen } \\
\text { Gemiddeld } \\
1996-1998\end{array}$ & $\begin{array}{c}\text { Voldoende } \\
\text { opleidingsbereid } \\
\%\end{array}$ \\
\hline $\begin{array}{l}\text { Overige industrie } \\
\text { Textiel } \\
\text { Hout- en bouwmaterialen } \\
\text { Papier } \\
\text { Grafische industrie }\end{array}$ & $\begin{array}{l}0,58 \\
0,30 \\
0,34 \\
0,74 \\
0,95\end{array}$ & $\begin{array}{l}25 \\
20 \\
16 \\
29 \\
36\end{array}$ \\
\hline Energie & 0,64 & 20 \\
\hline $\begin{array}{l}\text { Bouw en onroerend goed } \\
\text { Bouw } \\
\text { Exploitatie van onroerend goed }\end{array}$ & $\begin{array}{l}0,62 \\
0,60 \\
0,71\end{array}$ & $\begin{array}{l}28 \\
26 \\
40\end{array}$ \\
\hline Handel en reparatie & 0,42 & 20 \\
\hline $\begin{array}{l}\text { Transport en communicatie } \\
\text { Scheeps- en luchtvaart } \\
\text { Weg- en railvervoer } \\
\text { Communicatie } \\
\text { Bank- en verzekeringswezen } \\
\text { Bankwezen } \\
\text { Verzekeringswezen }\end{array}$ & $\begin{array}{l}0,48 \\
0,28 \\
0,43 \\
0,70 \\
0,85 \\
0,95 \\
0,66\end{array}$ & $\begin{array}{l}21 \\
11 \\
17 \\
31 \\
40 \\
47 \\
27\end{array}$ \\
\hline $\begin{array}{l}\text { Horeca en zakelijke dienstverlening } \\
\text { Horeca } \\
\text { Zakelijke dienstverlening } \\
\text { Overige commerciële dienstverlening }\end{array}$ & $\begin{array}{l}0,61 \\
0,27 \\
0,68 \\
0,56\end{array}$ & $\begin{array}{l}32 \\
16 \\
35 \\
30\end{array}$ \\
\hline $\begin{array}{l}\text { Kwartaire diensten } \\
\text { Gezondheidszorg } \\
\text { Overige kwartaire diensten }\end{array}$ & $\begin{array}{l}0,45 \\
0,45 \\
0,49\end{array}$ & $\begin{array}{l}24 \\
23 \\
26\end{array}$ \\
\hline $\begin{array}{l}\text { Overheid en onderwijs } \\
\text { Onderwijs } \\
\text { Overheid }\end{array}$ & $\begin{array}{l}0,83 \\
0,67 \\
0,97\end{array}$ & $\begin{array}{l}40 \\
35 \\
45\end{array}$ \\
\hline Totaal & 0,62 & 30 \\
\hline
\end{tabular}

Bron:OSA/ROA

Bereidheid tot een brede kwantitatieve inzet

De bereidheid zich qua werkuren flexibel op te stellen kan het beste worden bepaald aan de hand van gegevens omtrent de bereidheid van werknemers om op onregelmatige tijden, in ploegen- of wisseldiensten of in het weekend te werken. Bovendien zou in beeld moeten worden gebracht in hoeverre werknemers betaalde en onbetaalde overuren zouden willen maken. Vooralsnog zijn deze gegevens niet in de gewenste vorm beschikbaar. Zoals gezegd biedt het OSA-Aanbodpanel wel interessante aanknopingspunten voor de toekcmst. 
Bereidheid tot een brede kwalitatieve inzet

De bereidheid tot een brede kwalitatieve inzet wordt in beeld gebracht met behulp van het OSA-Aanbodpanel. Hierin wordt de vraag gesteld of een werknemer bereid is indien nodig werkzaamheden te verrichten die niet tot de eigen functie behoren. In tabel 4.10 wordt het percentage werknemers vermeld dat aangeeft bereid te zijn dergelijke werkzaamheden te verrichten. Zij zijn derhalve wat betreft de kwalitatieve inzetbereidheid voldoende employable.

Tabel 4.10

Bereidheid tot een brede kwalitatieve inzet, 1998

Bedrijfssector

Voldoende

Inzetbaar

$\%$

Landbouw en visserij

75

Tuinbouw

Veehouderij

75

Akkerbouw, bosbouw en visserij

Voeding

Vlees- en visbewerking

Overige voedingsproducten

Drank en tabaksproducten

82

85

87

Chemie

71

Basischemie

Eindproducten chemie

47

Kunststofverwerking

Metaal en elektrotechniek

Basismetaal

Metaalproducten

Machine-industrie

Elektrotechniek

Transportmiddelen

Overige industrie $\quad 85$

Textiel 92

Hout- en bouwmaterialen $\quad 83$

Papier $\quad 88$

Grafische industrie $\quad 83$

$\begin{array}{ll}\text { Energie } & 73\end{array}$

Bouw en onroerend goed $\quad 76$

Bouw $\quad 75$

Exploitatie van onroerend goed $\quad 82$

Handel en reparatie $\quad \mathbf{7 4}$

Transport en communicatie $\quad 68$

Scheeps- en luchtvaart $\quad 62$

Weg-en railvervoer $\quad 68$

$\begin{array}{ll}\text { Communicatie } & 71\end{array}$ 
Tabel 4.10 (vervolg)

Bereidheid tot een brede kwalitatieve inzet, 1998

\begin{tabular}{lc}
\hline Bedrijfssector & $\begin{array}{c}\text { Voldoende } \\
\text { Inzetbaar } \\
\%\end{array}$ \\
& \\
\hline Bank- en verzekeringswezen & 75 \\
Bankwezen & 74 \\
Verzekeringswezen & 77 \\
Horeca en zakelijke dienstverlening & 72 \\
Horeca & 65 \\
Zakelijke dienstverlening & 73 \\
Overige commerciële dienstverlening & 75 \\
Kwartaire diensten & 64 \\
Gezondheidszorg & 62 \\
Overige kwartaire diensten & 81 \\
Overheid en onderwijs & 72 \\
Onderwijs & 69 \\
Overheid & 75 \\
Totaal & 72 \\
\hline
\end{tabular}

Bron: OSA/ROA

Inspanning

Inspanningen die werknemers leveren om ervoor te zorgen dat hun employability op peil blijt, hebben eveneens betrekking op een drietal terreinen: mobiliteit, opleiding en inzetbaarheid. De variabelen die zouden moeten worden gemeten zijn dan ook mobiliteitsinspanning, opleidingsinspanning en inzetbaarheidsinspanning. Om deze drie vormen van inspanning optimaal in beeld te brengen is wederom een aantal subvariabelen onderscheiden. Mobiliteitsinspanning wordt onderverdeeld in functionele mobiliteitsinspanning en geografische mobiliteitsinspanning en inzetbaarheidsinspanning kan kwantitatief of kwalitatief zijn. Binnen opleidingsinspanning wordt geen onderverdeling gemaakt.

Belangrijkste databronnen bij het in beeld brengen van de diverse op employability gerichte inspanningen van werknemers zijn de Enquête Beroepsbevolking en het OSA-Aanbodpanel.

Inspanningen op het gebied van de functionele mobiliteit

Inspanningen op het gebied van de functionele mobiliteit kunnen het beste in beeld worden gebracht door te kijken naar de functie- en baanmobiliteit van werknemers. De databron die hierbij het beste kan worden gebruikt is het OSA-Aanbodpanel. Hierin wordt immers expliciet gevraagd of de arbeidsmarktsituatie in twee jaar tijd is veranderd en wat die verandering dan inhield. Verondersteld wordt dat hoe meer werknemers in een bedrijfssector van functie of van baan veranderen, des te gun- 
stiger is de employability van de werkenden in de desbetreffende sector. In tabel 4.11 wordt per bedrijfssector het percentage werknemers vermeld dat tussen 1996 en 1998 van functie of baan is veranderd.

Tabel 4.11

Functionele mobiliteitsinspanningen, 1996-1998

\begin{tabular}{|c|c|}
\hline Bedrijfssector & $\begin{array}{c}\text { Voldoende } \\
\text { Inspanningen } \\
\%\end{array}$ \\
\hline Landbouw en visserij & 17 \\
\hline Tuinbouw & - \\
\hline Veehouderij & 17 \\
\hline Akkerbouw, bosbouw en visserij & - \\
\hline Voeding & 19 \\
\hline Vlees- en visbewerking & 15 \\
\hline Overige voedingsproducten & 24 \\
\hline Drank en tabaksproducten & 8 \\
\hline Chemie & 32 \\
\hline Basischemie & 47 \\
\hline Eindproducten chemie & 15 \\
\hline Kunststofverwerking & - \\
\hline Metaal en elektrotechniek & 20 \\
\hline Basismetaal & 38 \\
\hline Metaalproducten & 26 \\
\hline Machine-industrie & 8 \\
\hline Elektrotechniek & 14 \\
\hline Transportmiddelen & 15 \\
\hline Overige industrie & 16 \\
\hline Textiel & 14 \\
\hline Hout- en bouwmaterialen & 15 \\
\hline Papier & 13 \\
\hline Grafische industrie & 19 \\
\hline Energie & 14 \\
\hline Bouw en onroerend goed & 21 \\
\hline Bouw & 21 \\
\hline Exploitatie van onroerend goed & 21 \\
\hline Handel en reparatie & 24 \\
\hline Transport en communicatie & 22 \\
\hline Scheeps- en luchtvaart & 8 \\
\hline Weg-en railvervoer & 23 \\
\hline Communicatie & 22 \\
\hline Bank- en verzekeringswezen & 19 \\
\hline Bankwezen & 27 \\
\hline Verzekeringswezen & 6 \\
\hline Horeca en zakelijke dienstverlening & 30 \\
\hline Horeca & 16 \\
\hline Zakelijke dienstverlening & 33 \\
\hline Overige commerciële dienstverlening & 30 \\
\hline
\end{tabular}


Tabel 4.11 (vervolg)

Functionele mobiliteitsinspanningen, 1996-1998

\begin{tabular}{lc}
\hline Bedrijfssector & $\begin{array}{c}\text { Voldoende } \\
\text { Inspanningen } \\
\%\end{array}$ \\
\hline Kwartaire diensten & 19 \\
Gezondheidszorg & 18 \\
Overige kwartaire diensten & 24 \\
Overheid en onderwijs & 13 \\
Onderwijs & 13 \\
Overheid & 14 \\
Totaal & 20 \\
\hline
\end{tabular}

Bron: OSA/ROA

Geografische mobiliteitsinspanning

Om de geografische mobiliteitsinspanning in een bepaalde bedrijfssector te kunnen bepalen zou moeten worden gekeken naar de inspanningen van werknemers om elders te gaan wonen om aldaar in dezelfde functie verder te werken of een andere functie te aanvaarden. Ook zou bekend moeten zijn hoever mensen op dit moment reizen om bij het werk te komen. De EBB biedt mogelijkheden om de huidige reistijd in kaart te brengen, zodat een indicatie kan worden verkregen van de geografische mobiliteitsinspanningen van werknemers. In tabel 4.12 wordt aan de hand van de dagelijkse reistijd van werknemers per bedrijfssector weergegeven in hoeverre men zich inspant op het gebied van de geografische mobiliteit. In de laatste kolom van de tabel wordt het percentage werknemers vermeld dat langer dan 23 minuten reist per dag om op het werk te komen. Deze werknemers leggen 'voldoende' geografische mobiliteitsinspanningen aan de dag. Zij zijn dan ook voldoende employable op dit aspect.

Tabel 4.12

Geografische mobiliteitsinspanningen (gemiddelde enkele reistijd per dag) van werknemers, naar bedrijfssector, 1999

\begin{tabular}{|c|c|c|c|c|c|}
\hline \multirow[t]{2}{*}{ Bedrijfssector } & $2 \min$ & $13-22 \mathrm{~min}$ & 23-32min & $>32 \mathrm{~min}$ & $\begin{array}{r}\text { Voldoende } \\
\text { Inspanningen }\end{array}$ \\
\hline & $\%$ & $\%$ & $\%$ & $\%$ & $\%$ \\
\hline Landbouw en visserij & 22 & 11 & 5 & 3 & 9 \\
\hline Tuinbouw & 29 & 18 & 7 & 5 & 12 \\
\hline Veehouderij & 17 & 7 & 5 & - & 5 \\
\hline Akkerbouw, bosbouw en visserij & 14 & 8 & - & - & - \\
\hline Voeding & 32 & 24 & 19 & 14 & 33 \\
\hline Vlees- en visbewerking & 33 & 21 & 19 & 14 & 33 \\
\hline Overige voedingsproducten & 34 & 25 & 19 & 13 & 32 \\
\hline Drank en tabaksproducten & 18 & 29 & 21 & 18 & 39 \\
\hline
\end{tabular}


Tabel 4.12 (vervolg)

Geografische mobiliteitsinspanningen (gemiddelde enkele reistijd per dag) van werknemers, naar bedrijfssector, 1999

\begin{tabular}{|c|c|c|c|c|c|}
\hline \multirow[t]{2}{*}{ Bedrijfssector } & $2 \min$ & $13-22 \mathrm{~min}$ & \multirow{2}{*}{$\begin{array}{r}23-32 \mathrm{~min} \\
\%\end{array}$} & \multirow{2}{*}{$\begin{array}{r}>32 \mathrm{~min} \\
\%\end{array}$} & $\begin{array}{l}\text { Voldoende } \\
\text {. }\end{array}$ \\
\hline & $\%$ & $\%$ & & & $\%$ \\
\hline Chemie & 27 & 33 & 20 & 14 & 34 \\
\hline Basischemie & 21 & 35 & 24 & 15 & 39 \\
\hline Eindproducten chemie & 26 & 29 & 20 & 18 & 38 \\
\hline Kunststofverwerking & 34 & 34 & 16 & 10 & 25 \\
\hline Metaal- en elektrotechniek & 27 & 28 & 20 & 16 & 36 \\
\hline Basismetaal & 25 & 27 & 21 & 23 & 45 \\
\hline Metaalproducten & 30 & 28 & 15 & 14 & 28 \\
\hline Machine-industrie & 25 & 28 & 18 & 13 & 32 \\
\hline Elektrotechniek & 25 & 26 & 25 & 15 & 41 \\
\hline Transportmiddelen & 25 & 29 & 21 & 20 & 41 \\
\hline Overige industrie & 28 & 25 & 16 & 12 & 28 \\
\hline Textiel & 32 & 38 & 14 & - & 14 \\
\hline Hout- en bouwmaterialen & 25 & 25 & 14 & 8 & 22 \\
\hline Papier & 39 & 24 & 24 & - & 24 \\
\hline Grafische industrie & 30 & 20 & 18 & 22 & 40 \\
\hline Energie & 17 & 22 & 27 & 21 & 48 \\
\hline Bouw en onroerend goed & 21 & 16 & 9 & 10 & 19 \\
\hline Bouw & 19 & 15 & 9 & 9 & 18 \\
\hline Exploitatie van onroerend goed & 34 & 24 & 11 & 17 & 28 \\
\hline Handel en reparatie & 31 & 23 & 16 & 14 & 30 \\
\hline Transport en communicatie & 22 & 23 & 17 & 20 & 37 \\
\hline Scheeps- en luchtvaart & - & 18 & 26 & 33 & 59 \\
\hline Weg- en railvervoer & 24 & 25 & 16 & 17 & 33 \\
\hline Communicatie & 25 & 21 & 15 & 25 & 40 \\
\hline Bank- en verzekeringswezen & 20 & 23 & 17 & 28 & 45 \\
\hline Bankwezen & 23 & 25 & 16 & 30 & 46 \\
\hline Verzekeringswezen & 17 & 21 & 18 & 25 & 43 \\
\hline Horeca en zakelijke & & & & & \\
\hline dienstverlening & 23 & 19 & 15 & 18 & 33 \\
\hline Horeca & 36 & 20 & 16 & 11 & 28 \\
\hline Zakelijke dienstverlening & 17 & 18 & 16 & 21 & 38 \\
\hline dienstverlening & 33 & 23 & 11 & 9 & 20 \\
\hline Kwartaire diensten & 26 & 24 & 17 & 16 & 32 \\
\hline Gezondheidszorg & 28 & 25 & 17 & 14 & 32 \\
\hline Overige kwartaire diensten & 15 & 18 & 14 & 23 & 37 \\
\hline Overheid en onderwijs & 25 & 25 & 19 & 21 & 40 \\
\hline Onderwijs & 28 & 26 & 17 & 19 & 37 \\
\hline Overheid & 23 & 24 & 20 & 22 & 43 \\
\hline Totaal & 25 & 22 & 16 & 16 & 32 \\
\hline
\end{tabular}


Opleidingsinspanningen

Opleidingsinspanningen kunnen worden gemeten aan de hand van gegevens omtrent het volgen van een opleiding of cursus op het moment van enquête. Omdat in de EBB deze vraag letterlijk wordt gesteld, is gebruik gemaakt van deze databron.

Tabel 4.13

Percentage werknemers dat een (bedrijfs)opleiding volgt, naar bedrijfssector, 1999

\begin{tabular}{|c|c|c|}
\hline Bedrijfssector & $\begin{array}{c}\text { Opleiding } \\
\%\end{array}$ & $\begin{array}{c}\text { Bedrijfsopleiding } \\
\%\end{array}$ \\
\hline Landbouw en visserij & 16 & 3 \\
\hline Tuinbouw & - & - \\
\hline Veehouderij & - & - \\
\hline Akkerbouw, bosbouw en visserij & - & - \\
\hline Voeding & 14 & 6 \\
\hline Vlees- en visverwerking & - & - \\
\hline Overige voedingsproducten & 14 & 5 \\
\hline Drank- en tabaksproducten & - & - \\
\hline Chemie & 17 & 7 \\
\hline Basischemie & 20 & 9 \\
\hline Eindproducten chemie & 17 & 8 \\
\hline Kunststofverwerking & - & - \\
\hline Metaal- en elektrotechniek & 14 & 6 \\
\hline Basismetaal & - & - \\
\hline Metaalproducten & 13 & 6 \\
\hline Machine-industrie & 15 & 6 \\
\hline Electrotechniek & 15 & 6 \\
\hline Transportmiddelen & 13 & 6 \\
\hline Overige industrie & 11 & 4 \\
\hline Textiel & - & - \\
\hline Hout- en bouwmaterialen & 9 & 3 \\
\hline Papier & - & - \\
\hline Grafische industrie & 15 & 4 \\
\hline Energie & 20 & 10 \\
\hline Bouw en onroerend goed & 15 & 6 \\
\hline Bouw & 14 & 6 \\
\hline Exploitatie van onroerend goed & 20 & 6 \\
\hline Handel en reparatie & 20 & 4 \\
\hline Transport en communicatie & 13 & 5 \\
\hline Scheeps- en luchtvaart & - & - \\
\hline Weg-en railvervoer & 11 & 3 \\
\hline Communicatie & 19 & 7 \\
\hline Bank- en verzekeringswezen & 30 & 13 \\
\hline Bankwezen & 31 & 16 \\
\hline Verzekeringswezen & 29 & 10 \\
\hline
\end{tabular}


Tabel 4.13 (vervolg)

Percentage werknemers dat een (bedrijfs)opleiding volgt, naar bedrijfssector, 1999

\begin{tabular}{lcc}
\hline Bedrijfssector & $\begin{array}{c}\text { Opleiding } \\
\%\end{array}$ & $\begin{array}{c}\text { Bedrijfsopleiding } \\
\%\end{array}$ \\
\hline Horeca en zakelijke dienstverlening & 23 & 5 \\
Horeca & 32 & 2 \\
Zakelijke dienstverlening & 22 & 6 \\
Overige commerciële dienstverlening & 17 & 4 \\
Kwartaire diensten & 16 & 5 \\
Gezondheidszorg & 16 & 6 \\
Overige kwartaire diensten & 17 & 4 \\
Overheid en onderwijs & 17 & 7 \\
Onderwijs & 16 & 5 \\
Overheid & 18 & 7 \\
Totaal & 18 & 6 \\
\hline
\end{tabular}

Bron: CBS

Inspanningen met betrekking tot een brede kwalitatieve inzetbaarheid

De inspanningen van werknemers om zich kwalitatief breed in te zetten, worden in beeld gebracht met gebruikmaking van gegevens uit het OSA-Aanbodpanel. De vraag hoe vaak werknemers werkzaamheden verrichten die eigenlijk tot een andere functie of afdeling behoren maakt het mogelijk de inspanningen met betrekking tot brede kwalitatieve inzet uitstekend te meten. In tabel 4.14 wordt het percentage werknemers dat zich vaak inzet voor werkzaamheden die eigenlijk tot een andere functie of afdeling behoren vermeld. Deze groep werknemers is wat dit aspect betreft voldoende employable.

Tabel 4.14

Kwalitatieve inzetbaarheidsinspanningen: percentage werknemers dat zich vaak breed heeft ingezet, naar bedrijfssector, 1998

\begin{tabular}{lc}
\hline Bedrijfssector & $\begin{array}{c}\text { Voldoende } \\
\text { Inspanning } \\
\%\end{array}$ \\
& 25 \\
Landbouw en visserij & - \\
Tuinbouw & 25 \\
Veehouderij & - \\
Akkerbouw, bosbouw en visserij & 21 \\
Voeding & 23 \\
Vlees- en visbewerking & 19 \\
Overige voedingsproducten & 25 \\
Drank en tabaksproducten & 25
\end{tabular}


Tabel 4.14 (vervolg)

Kwalitatieve inzetbaarheidsinspanningen: percentage werknemers dat zich vaak breed heeft ingezet, naar bedrijfssector, 1998

\begin{tabular}{|c|c|}
\hline Bedrijfssector & $\begin{array}{c}\text { Voldoende } \\
\text { Inspanning } \\
\%\end{array}$ \\
\hline $\begin{array}{l}\text { Chemie } \\
\text { Basischemie } \\
\text { Eindproducten chemie } \\
\text { Kunststofverwerking }\end{array}$ & $\begin{array}{r}21 \\
20 \\
23 \\
-\end{array}$ \\
\hline $\begin{array}{l}\text { Metaal en elektrotechniek } \\
\text { Basismetaal } \\
\text { Metaalproducten } \\
\text { Machine-industrie } \\
\text { Elektrotechniek } \\
\text { Transportmiddelen }\end{array}$ & $\begin{array}{r}17 \\
5 \\
24 \\
19 \\
7 \\
38\end{array}$ \\
\hline $\begin{array}{l}\text { Overige industrie } \\
\text { Textiel } \\
\text { Hout- en bouwmaterialen } \\
\text { Papier } \\
\text { Grafische industrie }\end{array}$ & $\begin{array}{l}17 \\
36 \\
19 \\
13 \\
10\end{array}$ \\
\hline Energie & 18 \\
\hline $\begin{array}{l}\text { Bouw en onroerend goed } \\
\text { Bouw } \\
\text { Exploitatie van onroerend goed }\end{array}$ & $\begin{array}{l}16 \\
16 \\
16\end{array}$ \\
\hline Handel en reparatie & 21 \\
\hline $\begin{array}{l}\text { Transport en communicatie } \\
\text { Scheeps- en luchtvaart } \\
\text { Weg- en railvervoer } \\
\text { Communicatie }\end{array}$ & $\begin{array}{l}14 \\
15 \\
14 \\
12\end{array}$ \\
\hline $\begin{array}{l}\text { Bank- en verzekeringswezen } \\
\text { Bankwezen } \\
\text { Verzekeringswezen }\end{array}$ & $\begin{array}{l}16 \\
15 \\
17\end{array}$ \\
\hline $\begin{array}{l}\text { Horeca en zakelijke dienstverlening } \\
\text { Horeca } \\
\text { Zakelijke dienstverlening } \\
\text { Overige commerciële dienstverlening }\end{array}$ & $\begin{array}{l}15 \\
19 \\
13 \\
18\end{array}$ \\
\hline $\begin{array}{l}\text { Kwartaire diensten } \\
\text { Gezondheidszorg } \\
\text { Overige kwartaire diensten }\end{array}$ & $\begin{array}{l}12 \\
11 \\
24\end{array}$ \\
\hline $\begin{array}{l}\text { Overheid en onderwijs } \\
\text { Onderwijs } \\
\text { Overheid }\end{array}$ & $\begin{array}{l}17 \\
20 \\
13\end{array}$ \\
\hline Totaal & 16 \\
\hline
\end{tabular}

Bron: OSA/ROA 
Inspanningen met betrekking tot een brede kwantitatieve inzetbaarheid

Om de inspanningen op het gebied van de kwantitatieve inzet in beeld te krijgen is inzicht nodig in de mate waarin werknemers te maken hebben met onregelmatige en bijzondere werktijden (zaterdagwerk etc.). Bovendien is informatie nodig over de mate waarin werknemers overuren maken, al dan niet betaald. Het maken van overuren duidt er immers op dat werknemers zich qua arbeidstijden breed inzetten.

De databron die in beide gevallen het meest geschikt is, is het OSA-Aanbodpanel, omdat in deze vragenlijst zowel wordt gevraagd naar het aantal onbetaalde, als het aantal betaalde overuren dat een werkende gemiddeld per week werkt, als naar het al dan niet werken onder bijzondere arbeidstijdenregimes.

In tabel 4.15 wordt allereerst inzicht verschaft in de mate waarin werknemers werken op onregelmatige tijden, in ploegen- of wisseldiensten of op zaterdag en zondag. Werknemers die aangeven dat tenminste één van de vier genoemde kenmerken van toepassing is op hun werkzaamheden zijn op het punt van de kwantitatieve inzetbaarheidsinspanning voldoende employable. Het percentage werknemers voor wie dat geldt staat vermeld in de laatste kolom van tabel 4.15

Tabel 4.15

Kwantitatieve inzetbaarheidsinspanning: flexibiliteit qua werktijden, naar bedrijfssector, 1998

\begin{tabular}{|c|c|c|c|c|c|}
\hline Bedrijfssector & $\begin{array}{c}\text { Onregelmatige } \\
\text { Werktijden } \\
\%\end{array}$ & $\begin{array}{c}\text { Ploegen } \\
\text { Wisseldienst } \\
\%\end{array}$ & $\begin{array}{c}\text { Zondag } \\
\text { werken } \\
\%\end{array}$ & $\begin{array}{l}\text { Zaterdag } \\
\text { werken } \\
\%\end{array}$ & $\begin{array}{l}\text { Voldoende } \\
\text { Inspanning } \\
\%\end{array}$ \\
\hline Landbouw en visserij & 17 & 0 & 0 & 8 & 17 \\
\hline Tuinbouw & - & - & - & - & - \\
\hline Veehouderij & 17 & - & - & 8 & 17 \\
\hline Akkerbouw, bosbouw en visserij & rij & - & - & - & - \\
\hline $\begin{array}{l}\text { Voeding } \\
\text { Vlees- en visbewerking } \\
\text { Overige voedingsproducten } \\
\text { Drank en tabaksproducten }\end{array}$ & $\begin{array}{l}36 \\
23 \\
46 \\
17\end{array}$ & $\begin{array}{l}37 \\
31 \\
41 \\
33\end{array}$ & $\begin{array}{r}26 \\
8 \\
35 \\
17\end{array}$ & $\begin{array}{l}48 \\
46 \\
60 \\
17\end{array}$ & $\begin{array}{l}65 \\
54 \\
76 \\
42\end{array}$ \\
\hline $\begin{array}{l}\text { Chemie } \\
\text { Basischemie } \\
\text { Eindproducten chemie }\end{array}$ & $\begin{array}{r}11 \\
13 \\
8\end{array}$ & $\begin{array}{l}18 \\
20 \\
15\end{array}$ & $\begin{array}{l}21 \\
27 \\
15\end{array}$ & $\begin{array}{l}21 \\
27 \\
15\end{array}$ & $\begin{array}{l}21 \\
27 \\
15\end{array}$ \\
\hline Kunststofverwerking & - & - & - & - & - \\
\hline $\begin{array}{l}\text { Metaal en elektrotechniek } \\
\text { Basismetaal } \\
\text { Metaalproducten } \\
\text { Machine-industrie } \\
\text { Elektrotechniek } \\
\text { Transportmiddelen }\end{array}$ & $\begin{array}{r}18 \\
24 \\
15 \\
31 \\
7 \\
8\end{array}$ & $\begin{array}{r}18 \\
48 \\
12 \\
22 \\
4 \\
8\end{array}$ & $\begin{array}{r}16 \\
43 \\
6 \\
17 \\
7 \\
15\end{array}$ & $\begin{array}{r}28 \\
48 \\
27 \\
36 \\
7 \\
23\end{array}$ & $\begin{array}{l}33 \\
57 \\
29 \\
44 \\
11 \\
23\end{array}$ \\
\hline $\begin{array}{l}\text { Overige industrie } \\
\text { Textiel } \\
\text { Hout- en bouwmaterialen } \\
\text { Papier } \\
\text { Grafische industrie }\end{array}$ & $\begin{array}{l}20 \\
36 \\
11 \\
31 \\
23\end{array}$ & $\begin{array}{r}21 \\
36 \\
9 \\
44 \\
23\end{array}$ & $\begin{array}{r}14 \\
21 \\
4 \\
25 \\
23\end{array}$ & $\begin{array}{l}30 \\
36 \\
24 \\
31 \\
36\end{array}$ & $\begin{array}{l}37 \\
50 \\
26 \\
50 \\
45\end{array}$ \\
\hline Energie & 27 & 18 & 27 & 38 & 48 \\
\hline
\end{tabular}


Tabel 4.15 (vervolg)

Kwantitatieve inzetbaarheidsinspanning: flexibiliteit qua werktijden, naar bedrijfssector, 1998

\begin{tabular}{|c|c|c|c|c|c|}
\hline $\begin{array}{l}\text { Onregel } \\
\text { Werkt }\end{array}$ & $\begin{array}{l}\text { Imatige } \\
\text { tijden } \\
\%\end{array}$ & $\begin{array}{c}\text { Ploegen } \\
\text { Wisseldienst } \\
\%\end{array}$ & $\begin{array}{l}\text { Zondag } \\
\text { werken } \\
\quad \%\end{array}$ & $\begin{array}{c}\text { Zaterdag } \\
\text { werken } \\
\%\end{array}$ & $\begin{array}{l}\text { Voldoende } \\
\text { Inspanning } \\
\%\end{array}$ \\
\hline $\begin{array}{l}\text { Bouw en onroerend goed } \\
\text { Bouw } \\
\text { Exploitatie van onroerend goed }\end{array}$ & $\begin{array}{l}13 \\
14 \\
12\end{array}$ & $\begin{array}{l}5 \\
5 \\
6\end{array}$ & $\begin{array}{l}9 \\
9 \\
9\end{array}$ & $\begin{array}{l}18 \\
19 \\
12\end{array}$ & $\begin{array}{l}23 \\
24 \\
18\end{array}$ \\
\hline Handel en reparatie & 23 & 11 & 18 & 48 & 57 \\
\hline $\begin{array}{l}\text { Transport en communicatie } \\
\text { Scheeps- en luchtvaart } \\
\text { Weg- en railvervoer } \\
\text { Communicatie }\end{array}$ & $\begin{array}{l}49 \\
54 \\
53 \\
37\end{array}$ & $\begin{array}{l}36 \\
46 \\
38 \\
24\end{array}$ & $\begin{array}{r}39 \\
69 \\
46 \\
7\end{array}$ & $\begin{array}{l}55 \\
85 \\
57 \\
42\end{array}$ & $\begin{array}{l}67 \\
85 \\
68 \\
59\end{array}$ \\
\hline $\begin{array}{l}\text { Bank- en verzekeringswezen } \\
\text { Bankwezen } \\
\text { Verzekeringswezen }\end{array}$ & $\begin{array}{l}8 \\
9 \\
6\end{array}$ & $\begin{array}{l}1 \\
2 \\
0\end{array}$ & $\begin{array}{l}2 \\
4 \\
0\end{array}$ & $\begin{array}{r}17 \\
22 \\
9\end{array}$ & $\begin{array}{l}20 \\
24 \\
14\end{array}$ \\
\hline $\begin{array}{l}\text { Horeca en zakelijke dienstverlening } \\
\text { Horeca } \\
\text { Zakelijke dienstverlening } \\
\text { Overige commerciële dienstverlening }\end{array}$ & $\begin{array}{l}24 \\
56 \\
19 \\
21\end{array}$ & $\begin{array}{r}9 \\
31 \\
6 \\
9\end{array}$ & $\begin{array}{l}24 \\
69 \\
16 \\
27\end{array}$ & $\begin{array}{l}33 \\
78 \\
21 \\
52\end{array}$ & $\begin{array}{l}41 \\
81 \\
29 \\
57\end{array}$ \\
\hline $\begin{array}{l}\text { Kwartaire diensten } \\
\text { Gezondheidszorg } \\
\text { Overige kwartaire diensten }\end{array}$ & $\begin{array}{l}39 \\
38 \\
42\end{array}$ & $\begin{array}{l}35 \\
36 \\
26\end{array}$ & $\begin{array}{l}48 \\
49 \\
42\end{array}$ & $\begin{array}{l}51 \\
51 \\
50\end{array}$ & $\begin{array}{l}56 \\
56 \\
58\end{array}$ \\
\hline $\begin{array}{l}\text { Overheid en onderwijs } \\
\text { Onderwijs } \\
\text { Overheid }\end{array}$ & $\begin{array}{l}17 \\
11 \\
23\end{array}$ & $\begin{array}{r}9 \\
1 \\
17\end{array}$ & $\begin{array}{r}15 \\
5 \\
24\end{array}$ & $\begin{array}{r}19 \\
9 \\
30\end{array}$ & $\begin{array}{l}26 \\
18 \\
34\end{array}$ \\
\hline Totaal & 25 & 17 & 23 & 34 & 42 \\
\hline
\end{tabular}

Bron: OSA/ROA

Ook in de EBB wordt overigens gevraagd of werkenden 's avonds, 's nachts, op zaterdag en op zondag werken en of iemand in ploegendienst werkt. De vraag of een werkende met onregelmatige werktijden te maken heeft wordt echter in de EBB niet gesteld en met name deze vraag is interessant bij het in beeld brengen van het vermogen kwantitatief breed inzetbaar te zijn.

Tabel 4.16

Kwantitatieve inzetbaarheidsinspanningen: betaalde en onbetaalde overuren, naar bedrijfssector, 1998

\begin{tabular}{lccccc}
\hline Bedrijfssector & Geen & $\begin{array}{c}\text { Alleen } \\
\text { betaald } \\
\%\end{array}$ & $\begin{array}{c}\text { Alleen } \\
\text { onbetaald } \\
\%\end{array}$ & $\begin{array}{c}\text { Zowel betaald onbetaald } \\
\text { als }\end{array}$ & $\begin{array}{c}\text { Voldoende } \\
\text { Inspanning } \\
\%\end{array}$ \\
\hline Landbouw en visserij & 67 & 25 & 8 & 0 & 33 \\
Tuinbouw & - & - & - & - & - \\
Veehouderij & 67 & 25 & 8 & 0 & 33 \\
Akkerbouw, bosbouw en visserij & - & - & - & - & -
\end{tabular}


Tabel 4.16 (vervolg)

Kwantitatieve inzetbaarheidsinspanningen: betaalde en onbetaalde overuren, naar bedrijfssector, 1998

\begin{tabular}{|c|c|c|c|c|c|}
\hline Bedrijfssector & $\begin{array}{c}\text { Geen } \\
\%\end{array}$ & $\begin{array}{l}\text { Alleen } \\
\text { betaald } \\
\%\end{array}$ & $\begin{array}{l}\text { Alleen } \\
\text { onbetaald } \\
\%\end{array}$ & $\begin{array}{c}\text { Zowel betaald } \\
\text { als onbetaald } \\
\%\end{array}$ & $\begin{array}{c}\text { Voldoende } \\
\text { Inspanning } \\
\%\end{array}$ \\
\hline $\begin{array}{l}\text { Voeding } \\
\text { Vlees- en visbewerking } \\
\text { Overige voedingsproducten } \\
\text { Drank en tabaksproducten }\end{array}$ & $\begin{array}{l}40 \\
38 \\
36 \\
55\end{array}$ & $\begin{array}{l}37 \\
38 \\
36 \\
36\end{array}$ & $\begin{array}{r}17 \\
15 \\
19 \\
9\end{array}$ & $\begin{array}{l}7 \\
8 \\
8 \\
0\end{array}$ & $\begin{array}{l}60 \\
62 \\
64 \\
45\end{array}$ \\
\hline $\begin{array}{l}\text { Chemie } \\
\text { Basischemie } \\
\text { Eindproducten chemie } \\
\text { Kunststofverwerking }\end{array}$ & $\begin{array}{r}43 \\
47 \\
38 \\
-\end{array}$ & $\begin{array}{r}36 \\
33 \\
38 \\
-\end{array}$ & $\begin{array}{r}18 \\
13 \\
23 \\
-\end{array}$ & $\begin{array}{l}4 \\
7 \\
0 \\
-\end{array}$ & $\begin{array}{r}57 \\
53 \\
62 \\
-\end{array}$ \\
\hline $\begin{array}{l}\text { Metaal en elektrotechniek } \\
\text { Basismetaal } \\
\text { Metaalproducten } \\
\text { Machine-industrie } \\
\text { Elektrotechniek } \\
\text { Transportmiddelen }\end{array}$ & $\begin{array}{l}38 \\
24 \\
42 \\
33 \\
46 \\
50\end{array}$ & $\begin{array}{l}37 \\
38 \\
52 \\
36 \\
21 \\
33\end{array}$ & $\begin{array}{r}18 \\
24 \\
6 \\
19 \\
29 \\
17\end{array}$ & $\begin{array}{r}6 \\
14 \\
0 \\
11 \\
4 \\
0\end{array}$ & $\begin{array}{l}62 \\
76 \\
58 \\
67 \\
54 \\
50\end{array}$ \\
\hline $\begin{array}{l}\text { Overige industrie } \\
\text { Textiel } \\
\text { Hout- en bouwmaterialen } \\
\text { Papier } \\
\text { Grafische industrie }\end{array}$ & $\begin{array}{l}38 \\
21 \\
50 \\
20 \\
33\end{array}$ & $\begin{array}{l}35 \\
57 \\
28 \\
67 \\
23\end{array}$ & $\begin{array}{l}21 \\
21 \\
17 \\
13 \\
33\end{array}$ & $\begin{array}{r}5 \\
0 \\
6 \\
0 \\
10\end{array}$ & $\begin{array}{l}62 \\
79 \\
50 \\
80 \\
67\end{array}$ \\
\hline Energie & 48 & 31 & 11 & 9 & 52 \\
\hline $\begin{array}{l}\text { Bouw en onroerend goed } \\
\text { Bouw } \\
\text { Exploitatie van onroerend goed }\end{array}$ & $\begin{array}{l}53 \\
55 \\
44\end{array}$ & $\begin{array}{l}22 \\
24 \\
13\end{array}$ & $\begin{array}{l}19 \\
16 \\
34\end{array}$ & $\begin{array}{l}6 \\
5 \\
9\end{array}$ & $\begin{array}{l}47 \\
45 \\
56\end{array}$ \\
\hline Handel en reparatie & 52 & 23 & 20 & 5 & 48 \\
\hline $\begin{array}{l}\text { Transport en communicatie } \\
\text { Scheeps- en luchtvaart } \\
\text { Weg- en railvervoer } \\
\text { Communicatie }\end{array}$ & $\begin{array}{l}47 \\
67 \\
46 \\
43\end{array}$ & $\begin{array}{r}38 \\
8 \\
42 \\
38\end{array}$ & $\begin{array}{l}12 \\
25 \\
10 \\
15\end{array}$ & $\begin{array}{l}2 \\
0 \\
2 \\
5\end{array}$ & $\begin{array}{l}53 \\
33 \\
54 \\
58\end{array}$ \\
\hline $\begin{array}{l}\text { Bank- en verzekeringswezen } \\
\text { Bankwezen } \\
\text { Verzekeringswezen }\end{array}$ & $\begin{array}{l}46 \\
42 \\
53\end{array}$ & $\begin{array}{l}15 \\
13 \\
18\end{array}$ & $\begin{array}{l}30 \\
35 \\
24\end{array}$ & $\begin{array}{r}9 \\
11 \\
6\end{array}$ & $\begin{array}{l}54 \\
58 \\
47\end{array}$ \\
\hline $\begin{array}{l}\text { Horeca en zakelijke dienstverlening } \\
\text { Horeca } \\
\text { Zakelijke dienstverlening } \\
\text { Overige commerciële dienstverlening }\end{array}$ & $\begin{array}{l}54 \\
59 \\
51 \\
61\end{array}$ & $\begin{array}{l}19 \\
31 \\
18 \\
18\end{array}$ & $\begin{array}{r}23 \\
9 \\
27 \\
18\end{array}$ & $\begin{array}{l}3 \\
0 \\
4 \\
2\end{array}$ & $\begin{array}{l}46 \\
41 \\
49 \\
39\end{array}$ \\
\hline $\begin{array}{l}\text { Kwartaire diensten } \\
\text { Gezondheidszorg } \\
\text { Overige kwartaire diensten }\end{array}$ & $\begin{array}{l}60 \\
60 \\
63\end{array}$ & $\begin{array}{l}15 \\
15 \\
11\end{array}$ & $\begin{array}{l}19 \\
19 \\
21\end{array}$ & $\begin{array}{l}6 \\
6 \\
5\end{array}$ & $\begin{array}{l}40 \\
40 \\
37\end{array}$ \\
\hline
\end{tabular}


Tabel 4.16 (vervolg)

Kwantitatieve inzetbaarheidsinspanningen: betaalde en onbetaalde overuren, naar bedrijfssector, 1998

\begin{tabular}{|c|c|c|c|c|c|}
\hline Bedrijfssector & $\begin{array}{c}\text { Geen } \\
\%\end{array}$ & $\begin{array}{l}\text { Alleen } \\
\text { betaald } \\
\%\end{array}$ & $\begin{array}{l}\text { Alleen } \\
\text { onbetaald } \\
\%\end{array}$ & $\begin{array}{c}\text { Zowel betaald } \\
\text { als onbetaald } \\
\%\end{array}$ & $\begin{array}{c}\text { Voldoende } \\
\text { Inspanning } \\
\%\end{array}$ \\
\hline $\begin{array}{l}\text { Overheid en onderwijs } \\
\text { Onderwijs } \\
\text { Overheid }\end{array}$ & $\begin{array}{l}54 \\
50 \\
58\end{array}$ & $\begin{array}{r}9 \\
2 \\
16\end{array}$ & $\begin{array}{l}34 \\
45 \\
22\end{array}$ & $\begin{array}{l}3 \\
3 \\
4\end{array}$ & $\begin{array}{l}46 \\
50 \\
42\end{array}$ \\
\hline Totaal & 51 & 21 & 22 & 5 & 49 \\
\hline
\end{tabular}

Bron: OSA/ROA

In tabel 4.16 is aangegeven of werknemers al dan niet betaalde overuren maken. Op basis van deze gegevens is vervolgens gekeken naar het percentage werknemers dat overuren maakt en derhalve voldoende employable is voor wat betreft hun inspanningen op het gebied van de kwantitatieve inzetbaarheid.

\section{Persoonlijke belemmeringen}

Om het beeld van de individuele employability van werknemers compleet te krijgen is ten slotte inzicht nodig in de mate waarin persoonlijke belemmeringen een rol kunnen spelen bij het al dan niet in staat zijn actief te blijven op de arbeidsmarkt. De belemmeringen die in deze eerste invulling van de Employability Monitor aan de orde komen zijn achtereenvolgens de gezinssituatie en het hebben van een arbeidshandicap.

\section{Gezinssituatie}

Om een goed beeld te krijgen van de mate waarin de gezinssituatie van werknemers de employability van werknemers belemmert, is allereerst de burgerlijke staat van belang. Werknemers kunnen in hun employability belemmerd worden wanneer zij een partner hebben, met name wanneer de partner werkt. Het hebben van een (werkende) partner kan immers bepalend zijn voor de keuze om op een gegeven moment een baan elders te accepteren. Behalve de burgerlijke staat moet echter ook worden bezien of een werknemer thuiswonende kinderen heeft. Wanneer een werknemer ongehuwd is en bovendien een of meerdere thuiswonende kinderen heeft, is de kans het grootst dat de werknemer beperkt wordt in zijn employability. Deze situatie maakt het voor werknemers immers moeilijker om bijvoorbeeld over te werken of opleidingen te volgen. Omdat de belemmering in het algemeen groter is naarmate de kinderen jonger zijn, is ook inzicht in de leeftijd van het jongste kind wenselijk.

Omdat het vooralsnog niet mogelijk is inzicht te krijgen in de door werknemers ervaren belemmeringen als gevolg van de gezinssituatie, wordt er in deze eerste opzet vanuit gegaan dat het hebben van thuiswonende kinderen de belangrijkste belemmering vormt. Voor werknemers die samenwonen of gehuwd zijn, zijn de belem- 
meringen daarbij geringer dan voor alleenstaande ouders. De databron die het meest geschikt is om de gezinssituatie goed in beeld te krijgen is de EBB.

In tabel 4.17 is per bedrijfssector het percentage werknemers vermeld dat door de gezinssituatie mogelijk wordt belemmerd in de employability. Hierbij wordt ervan uitgegaan dat de situatie belemmerend is wanneer er sprake is van thuiswonende kinderen jonger dan 17 jaar. Overigens worden in de tabel een aantal categorieën niet vermeld, waardoor de percentages niet optellen tot $100 \%$. Het betreft hier behalve de overigen-categorie ook de categorieën alleenstaand of gehuwd/samenwonend met anderen in huis en alleenstaand of gehuwd/samenwonend met kinderen ouder dan 17 jaar. Zoals reeds opgemerkt, kan het hebben van een werkende partner ook een belemmering vormen voor iemands employability. Op basis van de beschikbare databronnen is dit echter niet goed te meten. Mogelijk kan bij voortzetting van de monitor het al dan niet werken van de partner als variabele wel worden meegenomen.

\section{Arbeidshandicap}

Net als dat voor leeftijd gold is het ook voor de belemmerende factor arbeidshandicap van belang dat werknemers met een dergelijke handicap zich als gevolg van die handicap belemmerd voelen in hun loopbaan. Idealiter zou dan ook aan werknemers moeten worden gevraagd of zij zich als gevolg van een bepaalde arbeidshandicap moeilijker op de arbeidsmarkt kunnen handhaven. Bij gebrek aan een dergelijke vraagstelling in de beschikbare databronnen is de veronderstelling dat de employability van werknemers met een arbeidshandicap geringer is dan de employability van werknemers zonder arbeidshandicap. Omdat de gewenste data uit de EBB nog niet beschikbaar zijn, wordt in deze eerste opzet het hebben van een arbeidshandicap nog niet als belemmerende factor gemeten.

\subsection{Employability-behoefte}

De behoefte aan werknemers die employable zijn kan het beste worden bepaald door gebruik te maken van het OSA-Vraagpanel aangevuld met de Enquête Beroepsbevolking.

\section{Demografische ontwikkelingen}

Om de demografische ontwikkelingen in beeld te brengen moet worden gekeken naar de mate waarin binnen een bedrijfssector sprake is van vergrijzing. Hiertoe zijn gegevens nodig omtrent de leeftijd van werknemers binnen een bedrijfssector. De meest voor de hand liggende databron bij het bepalen van de mate van vergrijzing van de beroepsbevolking is de EBB. 


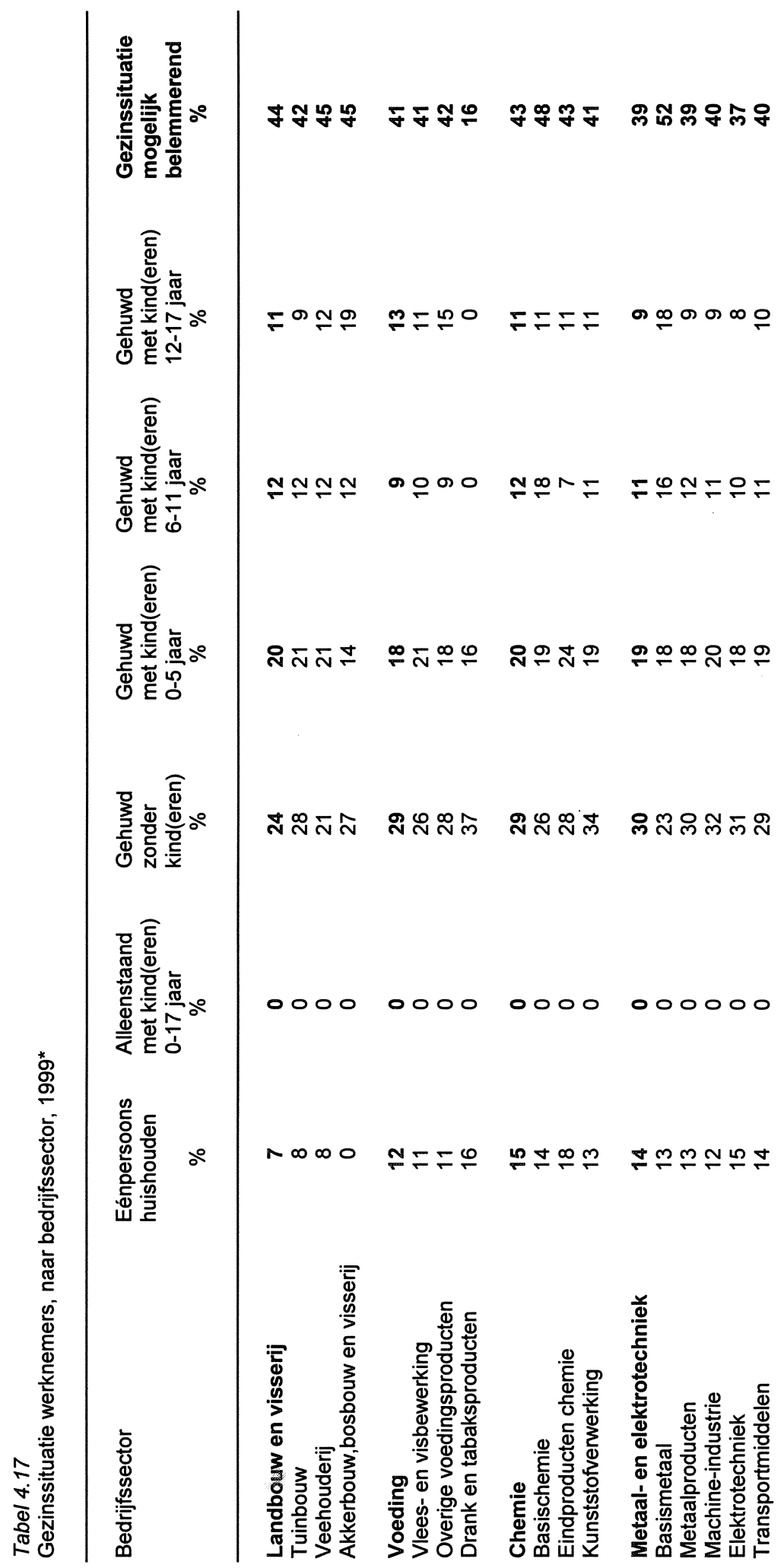




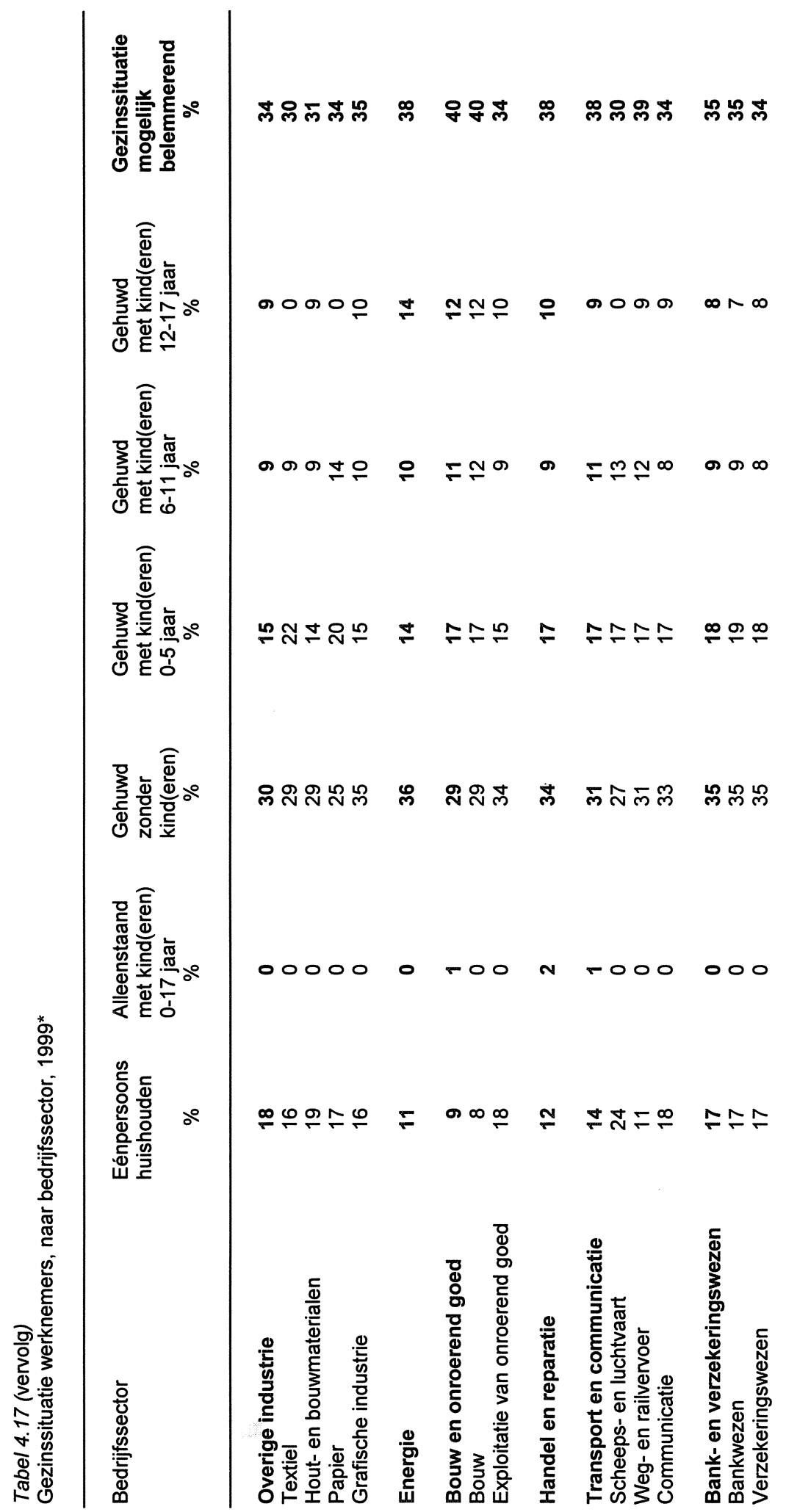




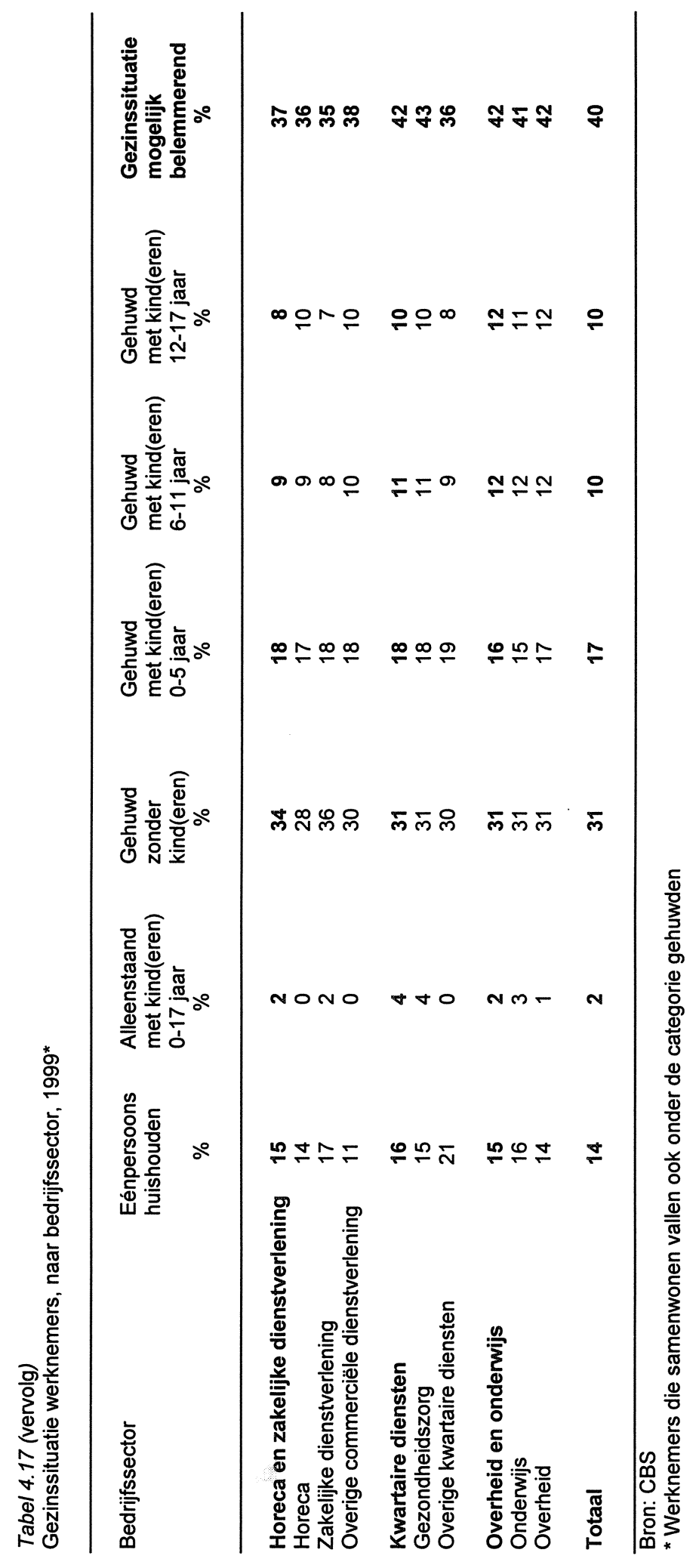


In tabel 4.18 wordt het percentage werknemers vermeld in de leeftijdscategorie 50 tot 65 jaar. Bovendien wordt het percentage werknemers in de leeftijdscategorie 15 tot 30 jaar vermeld. De behoefte aan werknemers die employable zijn is groter naarmate er in een sector relatief veel oudere werknemers zijn. Enerzijds is er in zogenaamde 'grijze' sectoren een grote kans dat op termijn de vervangingsvraag toeneemt, waardoor een beroep wordt gedaan op de employability van de werknemers die binnen de sector actief zijn. Zij zijn immers in eerste instantie de werknemers die de vervangingsvraag zullen opvullen. Anderzijds speelt onder oudere werknemers kennisveroudering een belangrijke rol. Om hun kennis op peil te houden en uit te breiden hebben oudere werknemers een relatief grote behoefte aan employabilitybeleid. Op basis van de verhouding tussen het aantal jongere en oudere werknemers in een bedrijfssector is de mate bepaald waarin er in een bepaalde sector sprake is van vergrijzing. In de laatste kolom van tabel 4.18 wordt dit verhoudingsgetal weergegeven. Wanneer de ratio groter is dan het gemiddelde van 0,6 , kan worden gesproken van een relatief grote employability-behoefte. Is het getal in de laatste kolom groter dan 1 dan is zelfs sprake van een zeer grote behoefte aan employability.

Tabel 4.18

Percentage jongeren ( 15 tot 30 jaar) en percentage ouderen ( 50 tot 65 jaar), gemiddelde 19971999

\begin{tabular}{|c|c|c|c|}
\hline Bedrijfssector & $\begin{array}{r}\text { Jongeren } \\
(15 \text { tot } 30) \\
\%\end{array}$ & $\begin{array}{r}\text { Ouderen } \\
(50 \text { tot } 65) \\
\%\end{array}$ & $\begin{array}{r}\text { Ratio ouderen } \\
\text { jongeren }\end{array}$ \\
\hline $\begin{array}{l}\text { Landbouw en visserij } \\
\text { Tuinbouw } \\
\text { Veehouderij } \\
\text { Akkerbouw, bosbouw en visserij }\end{array}$ & $\begin{array}{l}25 \\
30 \\
22 \\
21\end{array}$ & $\begin{array}{l}27 \\
20 \\
29 \\
33\end{array}$ & $\begin{array}{l}1,1 \\
0,7 \\
1,3 \\
1,5\end{array}$ \\
\hline $\begin{array}{l}\text { Voeding } \\
\text { Vlees- en visverwerking } \\
\text { Overige voedingsproducten } \\
\text { Drank en tabaksproducten }\end{array}$ & $\begin{array}{l}30 \\
35 \\
30 \\
19\end{array}$ & $\begin{array}{l}16 \\
13 \\
16 \\
17\end{array}$ & $\begin{array}{l}0,5 \\
0,3 \\
0,6 \\
0,9\end{array}$ \\
\hline $\begin{array}{l}\text { Chemie } \\
\text { Basischemie } \\
\text { Eindproducten chemie } \\
\text { Kunststofverwerking }\end{array}$ & $\begin{array}{l}21 \\
15 \\
23 \\
27\end{array}$ & $\begin{array}{l}17 \\
22 \\
15 \\
13\end{array}$ & $\begin{array}{l}0,8 \\
1,5 \\
0,7 \\
0,5\end{array}$ \\
\hline $\begin{array}{l}\text { Metaal- en elektrotechniek } \\
\text { Basismetaal } \\
\text { Metaalproducten } \\
\text { Machine-industrie } \\
\text { Elektrotechniek } \\
\text { Transportmiddelen }\end{array}$ & $\begin{array}{l}26 \\
15 \\
30 \\
27 \\
25 \\
27\end{array}$ & $\begin{array}{l}17 \\
23 \\
16 \\
18 \\
17 \\
17\end{array}$ & $\begin{array}{l}0,7 \\
1,4 \\
0,5 \\
0,7 \\
0,7 \\
0,6\end{array}$ \\
\hline $\begin{array}{l}\text { Overige industrie } \\
\text { Textiel } \\
\text { Hout- en bouwmaterialen } \\
\text { Papier } \\
\text { Grafische industrie }\end{array}$ & $\begin{array}{l}22 \\
27 \\
22 \\
25 \\
24\end{array}$ & $\begin{array}{l}20 \\
21 \\
20 \\
17 \\
17\end{array}$ & $\begin{array}{l}0,9 \\
0,8 \\
0,9 \\
0,7 \\
0,7\end{array}$ \\
\hline
\end{tabular}


Tabel 4.18 (vervolg)

Percentage jongeren (15 tot 30 jaar) en percentage ouderen ( 50 tot 65 jaar), gemiddelde 19971999

\begin{tabular}{|c|c|c|c|}
\hline Bedrijfssector & $\begin{array}{r}\text { Jongeren } \\
(15 \text { tot } 30) \\
\%\end{array}$ & $\begin{array}{r}\text { Ouderen } \\
(50 \text { tot } 65) \\
\%\end{array}$ & $\begin{array}{c}\text { Ratio ouderen } \\
\text { jongeren }\end{array}$ \\
\hline Energie & 12 & 27 & 2,3 \\
\hline $\begin{array}{l}\text { Bouw en onroerend goed } \\
\text { Bouw } \\
\text { Exploitatie van onroerend goed }\end{array}$ & $\begin{array}{l}36 \\
31 \\
23\end{array}$ & $\begin{array}{l}15 \\
16 \\
20\end{array}$ & $\begin{array}{l}0,4 \\
0,5 \\
0,9\end{array}$ \\
\hline Handel en reparatie & 39 & 14 & 0,4 \\
\hline $\begin{array}{l}\text { Transport en communicatie } \\
\text { Scheeps- en luchtvaart } \\
\text { Weg- en railvervoer } \\
\text { Communicatie }\end{array}$ & $\begin{array}{l}25 \\
24 \\
25 \\
25\end{array}$ & $\begin{array}{l}16 \\
14 \\
18 \\
13\end{array}$ & $\begin{array}{l}0,7 \\
0,6 \\
0,7 \\
0,5\end{array}$ \\
\hline $\begin{array}{l}\text { Bank- en verzekeringswezen } \\
\text { Bankwezen } \\
\text { Verzekeringswezen }\end{array}$ & $\begin{array}{l}29 \\
30 \\
28\end{array}$ & $\begin{array}{l}13 \\
12 \\
14\end{array}$ & $\begin{array}{l}0,4 \\
0,4 \\
0,5\end{array}$ \\
\hline $\begin{array}{l}\text { Horeca en zakelijke dienstverlening } \\
\text { Horeca } \\
\text { Zakelijke dienstverlening } \\
\text { Overige commerciële dienstverlening }\end{array}$ & $\begin{array}{l}35 \\
48 \\
32 \\
33\end{array}$ & $\begin{array}{l}13 \\
11 \\
13 \\
16\end{array}$ & $\begin{array}{l}0,4 \\
0,2 \\
0,4 \\
0,5\end{array}$ \\
\hline $\begin{array}{l}\text { Kwartaire diensten } \\
\text { Gezondheidszorg } \\
\text { Overige kwartaire diensten }\end{array}$ & $\begin{array}{l}23 \\
24 \\
20\end{array}$ & $\begin{array}{l}15 \\
14 \\
20\end{array}$ & $\begin{array}{l}0,7 \\
0,6 \\
1,0\end{array}$ \\
\hline $\begin{array}{l}\text { Overheid en onderwijs } \\
\text { Onderwijs } \\
\text { Overheid }\end{array}$ & $\begin{array}{l}16 \\
13 \\
18\end{array}$ & $\begin{array}{l}23 \\
27 \\
19\end{array}$ & $\begin{array}{l}1,5 \\
2,1 \\
1,1\end{array}$ \\
\hline Totaal & 28 & 17 & 0,6 \\
\hline
\end{tabular}

Bron: CBS/ROA

\section{Economische ontwikkelingen}

De mate waarin bedrijfssectoren gevoelig zijn voor economische ontwikkelingen wordt bepaald aan de hand van gegevens omtrent gevoeligheid voor de economische conjunctuur. In het OSA-Vraagpanel wordt gevraagd of een organisatie gevoelig is voor schommelingen in de economische conjunctuur. In tabel 4.19 wordt per bedrijfssector het percentage bedrijven vermeld dat aangeeft in sterke mate gevoelig te zijn voor dergelijke schommelingen. Hoe hoger dit percentage des te groter de behoefte aan werknemers die employable zijn. Immers, bij fluctuaties in de werkgelegenheid is er een grote behoefte aan werknemers met een brede inzetbaarheid en een hoge mobiliteit. 
Tabel 4.19

Percentage bedrijven dat gevoelig is voor economische schommelingen, 1997

Bedrijfssector

Landbouw en visserij

Tuinbouw

Veehouderi]

Akkerbouw, bosbouw en visserij

Voeding

Vlees- en visbewerking

Overige voedingsproducten

Drank en tabaksproducten

Chemie

Basischemie

Eindproducten chemie

Kunststofverwerking

Metaal en elektrotechniek

Basismetaal

Metaalproducten

Machine-industrie

Elektrotechniek

Transportmiddelen

Overige industrie

Textiel

Hout- en bouwmaterialen

Papier

Grafische industrie

Energie

Bouw en onroerend goed

Bouw

Exploitatie van onroerend goed

Handel en reparatie

Transport en communicatie

Scheeps- en luchtvaart

Weg-en railvervoer

Communicatie

Bank- en verzekeringswezen

Bankwezen

Verzekeringswezen

Horeca en zakelijke dienstverlening

Zakelijke dienstverlening

Kwartaire diensten

Overige kwartaire diensten 
Tabel 4.19 (vervolg)

Percentage bedrijven dat gevoelig is voor economische schommelingen, 1997

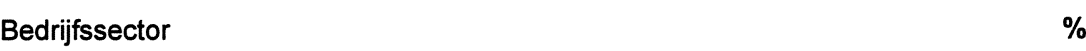

Overheid en onderwijs $\quad 6$

Onderwijs $\quad 5$

$\begin{array}{lr}\text { Overheid } & 8\end{array}$

$\begin{array}{ll}\text { Totaal } & 35\end{array}$

Bron: OSA/ROA

Technologische ontwikkelingen

Misschien wel de belangrijkste invloedsfactor voor wat betreft de behoefte aan werknemers die employable zijn is de mate waarin bedrijfssectoren te maken hebben met technologische vernieuwingen. Immers, technologische vernieuwingen vereisen doorgaans dat werkenden aanvullende opleidingen volgen om hun competenties upto-date te houden en leiden soms ook tot taakverschuivingen binnen een functie of veranderingen van functie. Om de intensiteit van deze technologische vernieuwingen in beeld te brengen ligt het gebruik van het OSA-Vraagpanel het meest voor de hand. In dit panel wordt gevraagd of er nieuwe technieken zijn geïntroduceerd in een tijdsbestek van twee jaar en in hoeverre deze introductie gevolgen heeft gehad voor het personeel.

In tabel 4.20 wordt het percentage bedrijven weergegeven dat aangeeft dat er in de afgelopen twee jaar een technologische of technische verandering is doorgevoerd. Hoe hoger dit percentage des te groter is ook de behoefte aan werknemers die employable zijn.

Tabel 4.20

Percentage bedrijven dat als gevolg van technologische veranderingen behoefte heeft aan employability naar bedrijfssector en bedrijfsgrootte, 1997

Bedrijfssector $\quad \%$

Landbouw en visserij

Tuinbouw 27

$\begin{array}{ll}\text { Veehouderij } & 19\end{array}$

Akkerbouw, bosbouw en visserij

Voeding $\quad 41$

Vlees- en visbewerking $\quad 67$

Overige voedingsproducten $\quad 33$

Drank en tabaksproducten

$\begin{array}{ll}\text { Chemie } & 31\end{array}$

Basischemie

Eindproducten chemie 
Tabel 4.20 (vervolg)

Percentage bedrijven dat als gevolg van technologische veranderingen behoefte heeft aan employability naar bedrijfssector en bedrijfsgrootte, 1997

\begin{tabular}{|c|c|}
\hline Bedrijfssector & $\%$ \\
\hline $\begin{array}{l}\text { Metaal en elektrotechniek } \\
\text { Basismetaal } \\
\text { Metaalproducten } \\
\text { Machine-industrie } \\
\text { Elektrotechniek } \\
\text { Transportmiddelen }\end{array}$ & $\begin{array}{l}33 \\
69 \\
28 \\
31 \\
32 \\
27\end{array}$ \\
\hline $\begin{array}{l}\text { Overige industrie } \\
\text { Textiel } \\
\text { Hout- en bouwmaterialen } \\
\text { Papier } \\
\text { Grafische industrie }\end{array}$ & $\begin{array}{r}32 \\
0 \\
29 \\
9 \\
50\end{array}$ \\
\hline Energie & 0 \\
\hline $\begin{array}{l}\text { Bouw en onroerend goed } \\
\text { Bouw } \\
\text { Exploitatie van onroerend goed }\end{array}$ & $\begin{array}{r}17 \\
19 \\
6\end{array}$ \\
\hline Handel en reparatie & 23 \\
\hline $\begin{array}{l}\text { Transport en communicatie } \\
\text { Scheeps- en luchtvaart } \\
\text { Weg- en railvervoer } \\
\text { Communicatie }\end{array}$ & $\begin{array}{r}14 \\
15 \\
13 \\
-\end{array}$ \\
\hline $\begin{array}{l}\text { Bank- en verzekeringswezen } \\
\text { Bankwezen } \\
\text { Verzekeringswezen }\end{array}$ & $\begin{array}{l}30 \\
27 \\
32\end{array}$ \\
\hline $\begin{array}{l}\text { Horeca en zakelijke dienstverlening } \\
\text { Horeca } \\
\text { Zakelijke dienstverlening } \\
\text { Overige commerciële dienstverlening }\end{array}$ & $\begin{array}{l}25 \\
17 \\
30 \\
24\end{array}$ \\
\hline $\begin{array}{l}\text { Kwartaire diensten } \\
\text { Gezondheidszorg } \\
\text { Overige kwartaire diensten }\end{array}$ & $\begin{array}{l}29 \\
27 \\
36\end{array}$ \\
\hline $\begin{array}{l}\text { Overheid en onderwijs } \\
\text { Onderwijs } \\
\text { Overheid }\end{array}$ & $\begin{array}{l}25 \\
24 \\
33\end{array}$ \\
\hline
\end{tabular}

\section{Bron: OSA}

Nadeel bij het gebruiken van het OSA-Vraagpanel is dat alleen maar informatie beschikbaar komt over technologische vernieuwingen in het verleden, terwijl met het oog op de behoefte aan employability ook de ontwikkelingen in het heden en de nabije toekomst van belang zijn. Mogelijk zou hiermee in volgende golven van het OSAVraagpanel rekening kunnen worden gehouden. 


\section{Organisatorische ontwikkelingen}

Technologische vernieuwingen gaan doorgaans ook gepaard met organisatorische veranderingen. Deze organisatorische veranderingen hebben vaak echter dermate specifieke gevolgen voor werknemers dat zij als aparte invloedsfactor moeten worden belicht. Organisatorische veranderingen worden in beeld gebracht met behulp van het OSA-Vraagpanel, waar de vraag wordt gesteld of bedrijven in de komende twee jaar veranderingen verwachten in hun omgeving of in het bedrijf zelf. Aan de hand van deze twee variabelen wordt in tabel 4.21 een beeld geschetst van de behoefte aan employability als gevolg van interne en externe organisatorische veranderingen.

In tabel 4.21 wordt per bedrijfssector aangegeven welk percentage bedrijven verwacht dat in hun omgeving of in het bedrijf zelf in de komende twee jaar iets zal veranderen. Naarmate dit percentage groter is neemt ook de behoefte aan werknemers die employable zijn toe. In de laatste kolom wordt het percentage bedrijven vermeld dat aangeeft met tenminste een van de twee genoemde organisatorische veranderingen te maken denkt te zullen krijgen. Voor deze bedrijven geldt dat er als gevolg van de organisatorische veranderingen een relatief grote employability-behoefte bestaat.

Tabel 4.21

Percentage bedrijven dat voor de periode 1997-1999 organisatorische veranderingen verwachtte, naar bedrijfssector

\begin{tabular}{|c|c|c|c|}
\hline Bedrijfssector & $\begin{array}{c}\text { Verandering } \\
\text { Omgeving } \\
\%\end{array}$ & $\begin{array}{c}\text { Verandering } \\
\text { Bedrijf } \\
\\
\%\end{array}$ & $\begin{array}{c}\text { Employability- } \\
\text { behoefte vanuit } \\
\text { organisatorische } \\
\text { veranderingen } \\
\%\end{array}$ \\
\hline Landbouw en visserij & 42 & 51 & 61 \\
\hline Tuinbouw & 47 & 64 & 74 \\
\hline Veehouderii & 36 & 33 & 43 \\
\hline Akkerbouw, bosbouw en visserij & - & - & - \\
\hline Voeding & 35 & 49 & 60 \\
\hline Vlees-en visbewerking & 23 & 38 & 42 \\
\hline Overige voedingsproducten & 41 & 52 & 67 \\
\hline Drank- en tabaksproducten & - & - & - \\
\hline Chemie & 38 & 48 & 55 \\
\hline Basischemie & - & - & - \\
\hline Eindproducten chemie & _- & - & - \\
\hline Kunststofverwerking & 29 & 50 & 53 \\
\hline Metaal en elektrotechniek & 26 & 58 & 62 \\
\hline Basismetaal & 31 & 54 & 54 \\
\hline Metaalproducten & 20 & 59 & 62 \\
\hline Machine-industrie & 19 & 58 & 61 \\
\hline Elektrotechniek & 52 & 57 & 67 \\
\hline Transportmiddelen & 10 & 64 & 64 \\
\hline
\end{tabular}


Tabel 4.21 (vervolg)

Percentage bedrijven dat voor de periode 1997-1999 organisatorische veranderingen verwachtte, naar bedrijfssector

\begin{tabular}{|c|c|c|c|}
\hline Bedrijfssector & $\begin{array}{c}\text { Verandering } \\
\text { Omgeving } \\
\%\end{array}$ & $\begin{array}{c}\text { Verandering } \\
\text { Bedrijf } \\
\\
\%\end{array}$ & $\begin{array}{c}\text { Employability- } \\
\text { behoefte vanuit } \\
\text { organisatorische } \\
\text { veranderingen } \\
\%\end{array}$ \\
\hline $\begin{array}{l}\text { Overige industrie } \\
\text { Textiel } \\
\text { Hout- en bouwmaterialen } \\
\text { Papier } \\
\text { Grafische industrie }\end{array}$ & $\begin{array}{l}41 \\
50 \\
35 \\
50 \\
41\end{array}$ & $\begin{array}{l}59 \\
21 \\
63 \\
50 \\
67\end{array}$ & $\begin{array}{l}69 \\
50 \\
67 \\
73 \\
76\end{array}$ \\
\hline Energie & - & - & $56^{*}$ \\
\hline $\begin{array}{l}\text { Bouw en onroerend goed } \\
\text { Bouw } \\
\text { Exploitatie van onroerend goed }\end{array}$ & $\begin{array}{l}31 \\
26 \\
60\end{array}$ & $\begin{array}{l}42 \\
40 \\
56\end{array}$ & $\begin{array}{l}53 \\
50 \\
76\end{array}$ \\
\hline Handel en reparatie & 37 & 56 & 68 \\
\hline $\begin{array}{l}\text { Transport en communicatie } \\
\text { Scheeps- en luchtvaart } \\
\text { Weg- en railvervoer } \\
\text { Communicatie }\end{array}$ & $\begin{array}{r}30 \\
31 \\
28 \\
-\end{array}$ & $\begin{array}{r}43 \\
38 \\
43 \\
-\end{array}$ & $\begin{array}{r}55 \\
39 \\
55 \\
-\end{array}$ \\
\hline $\begin{array}{l}\text { Bank- en verzekeringswezen } \\
\text { Bankwezen } \\
\text { Verzekeringswezen }\end{array}$ & $\begin{array}{l}70 \\
67 \\
73\end{array}$ & $\begin{array}{l}73 \\
82 \\
64\end{array}$ & $\begin{array}{l}84 \\
82 \\
82\end{array}$ \\
\hline $\begin{array}{l}\text { Horeca en zakelijke dienstverlening } \\
\text { Horeca } \\
\text { Zakelijke dienstverlening } \\
\text { Overige commerciële dienstverlening }\end{array}$ & $\begin{array}{l}40 \\
38 \\
47 \\
29\end{array}$ & $\begin{array}{l}55 \\
50 \\
62 \\
45\end{array}$ & $\begin{array}{l}65 \\
63 \\
71 \\
52\end{array}$ \\
\hline $\begin{array}{l}\text { Kwartaire diensten } \\
\text { Gezondheidszorg } \\
\text { Overige kwartaire diensten }\end{array}$ & $\begin{array}{l}72 \\
81 \\
47\end{array}$ & $\begin{array}{l}68 \\
76 \\
47\end{array}$ & $\begin{array}{l}84 \\
91 \\
65\end{array}$ \\
\hline $\begin{array}{l}\text { Overheid en onderwijs } \\
\text { Onderwijs } \\
\text { Overheid }\end{array}$ & $\begin{array}{l}66 \\
67 \\
54\end{array}$ & $\begin{array}{l}76 \\
76 \\
79\end{array}$ & $\begin{array}{l}89 \\
89 \\
83\end{array}$ \\
\hline Totaal & 43 & 58 & 67 \\
\hline
\end{tabular}

Bron: OSA

* Gezien het geringe aantal bedrijven dat de sector vertegenwoordigd in de steekproef moeten de resultaten met enige voorzichtigheid worden behandeld

Arbeidsomstandigheden

De mate waarin werknemers in bedrijven worden geconfronteerd met fysiek, dan wel psychisch belastende arbeidsomstandigheden kan het beste in beeld worden gebracht door gebruik te maken van de EBB. In deze enquête wordt aan respondenten gevraagd of zij al dan niet te maken hebben met fysiek belastende factoren als: 
- lawaai;

- kracht zetten, bijvoorbeeld bij tillen, duwen, trekken, sjouwen;

- beeldschermwerk.

Bovendien wordt in de EBB gevraagd of mensen onder hoge tijdsdruk moeten werken en of mensen het idee hebben dat de werkdruk toeneemt, afneemt of gelijk blijft. Beide factoren leiden tot psychische belasting.

Fysieke belasting

In tabel 4.22 wordt allereerst per bedrijfssector het percentage werkenden vermeld dat aangeeft te maken te hebben met de drie onderscheiden fysiek belastende arbeidsomstandigheden, te weten: lawaai, kracht zetten en beeldschermwerk. In de laatste tabel van tabel 4.22 wordt ten slotte voor elke bedrijfssector een indexcijfer vermeld. Dit indexcijfer geeft de positie van een bedrijfssector aan ten opzichte van het totaalgemiddelde dat op 100 is gesteld. Naarmate het indexcijfer hoger is, is de behoefte aan employability, doordat fysieke belasting een rol speelt, eveneens groter.

\section{Tabel 4.22}

Percentage werknemers dat te maken heeft met fysiek belastende arbeidsomstandigheden, naar bedrijfssector, 1998

\begin{tabular}{|c|c|c|c|c|}
\hline Bedrijfssector & $\begin{array}{c}\text { Lawaai } \\
\text { \% }\end{array}$ & $\begin{array}{c}\text { Kracht } \\
\%\end{array}$ & $\begin{array}{c}\text { Beeldscherm } \\
\qquad \%\end{array}$ & $\begin{array}{l}\text { Behoefte aan } \\
\text { employability } \\
\text { Indexcijfer* }\end{array}$ \\
\hline $\begin{array}{l}\text { Landbouw en visserij } \\
\text { Tuinbouw } \\
\text { Veehouderij } \\
\text { Akkerbouw, bosbouw en visserij }\end{array}$ & $\begin{array}{l}28 \\
19 \\
36 \\
45\end{array}$ & $\begin{array}{l}63 \\
58 \\
71 \\
61\end{array}$ & $\begin{array}{r}20 \\
20 \\
20 \\
-\end{array}$ & $\begin{array}{r}117 \\
99 \\
138 \\
144\end{array}$ \\
\hline $\begin{array}{l}\text { Voeding } \\
\text { Vlees- en visbewerking } \\
\text { Overige voedingsproducten } \\
\text { Drank en tabaksproducten }\end{array}$ & $\begin{array}{l}43 \\
55 \\
41 \\
37\end{array}$ & $\begin{array}{l}46 \\
63 \\
44 \\
28\end{array}$ & $\begin{array}{l}45 \\
22 \\
48 \\
64\end{array}$ & $\begin{array}{l}139 \\
161 \\
134 \\
123\end{array}$ \\
\hline $\begin{array}{l}\text { Chemie } \\
\text { Basischemie } \\
\text { Eindproducten chemie } \\
\text { Kunststofverwerking }\end{array}$ & $\begin{array}{l}37 \\
38 \\
24 \\
56\end{array}$ & $\begin{array}{l}34 \\
31 \\
26 \\
48\end{array}$ & $\begin{array}{l}70 \\
87 \\
72 \\
49\end{array}$ & $\begin{array}{l}132 \\
139 \\
104 \\
164\end{array}$ \\
\hline $\begin{array}{l}\text { Metaal en elektrotechniek } \\
\text { Basismetaal } \\
\text { Metaalproducten } \\
\text { Machine-industrie } \\
\text { Elektrotechniek } \\
\text { Transportmiddelen }\end{array}$ & $\begin{array}{l}44 \\
54 \\
58 \\
43 \\
23 \\
51\end{array}$ & $\begin{array}{l}40 \\
37 \\
54 \\
43 \\
22 \\
48\end{array}$ & $\begin{array}{l}54 \\
68 \\
39 \\
58 \\
70 \\
41\end{array}$ & $\begin{array}{r}139 \\
160 \\
167 \\
145 \\
98 \\
152\end{array}$ \\
\hline $\begin{array}{l}\text { Overige industrie } \\
\text { Textiel } \\
\text { Hout- en bouwmaterialen } \\
\text { Papier } \\
\text { Grafische industrie }\end{array}$ & $\begin{array}{l}38 \\
41 \\
41 \\
58 \\
27\end{array}$ & $\begin{array}{l}39 \\
36 \\
46 \\
43 \\
25\end{array}$ & $\begin{array}{l}48 \\
40 \\
34 \\
65 \\
70\end{array}$ & $\begin{array}{l}126 \\
122 \\
130 \\
171 \\
107\end{array}$ \\
\hline
\end{tabular}


Tabel 4.22 (vervolg)

Percentage werknemers dat te maken heeft met fysiek belastende arbeidsomstandigheden, naar bedrijfssector, 1998

\begin{tabular}{|c|c|c|c|c|}
\hline Bedrijfssector & $\begin{array}{l}\text { Lawaai } \\
\qquad \%\end{array}$ & $\begin{array}{c}\text { Kracht } \\
\%\end{array}$ & $\begin{array}{c}\text { Beeldscherm } \\
\%\end{array}$ & $\begin{array}{l}\text { Behoefte aan } \\
\text { employability } \\
\text { Indexcijfer* }\end{array}$ \\
\hline Energie & 24 & 25 & 80 & 108 \\
\hline $\begin{array}{l}\text { Bouw en onroerend goed } \\
\text { Bouw } \\
\text { Exploitatie van onroerend goed }\end{array}$ & $\begin{array}{r}39 \\
43 \\
6\end{array}$ & $\begin{array}{l}59 \\
64 \\
12\end{array}$ & $\begin{array}{l}31 \\
25 \\
81\end{array}$ & $\begin{array}{r}137 \\
146 \\
68\end{array}$ \\
\hline Handel en reparatie & 15 & 41 & 54 & 96 \\
\hline $\begin{array}{l}\text { Transport en communicatie } \\
\text { Scheeps- en luchtvaart } \\
\text { Weg- en railvervoer } \\
\text { Communicatie }\end{array}$ & $\begin{array}{l}21 \\
46 \\
20 \\
12\end{array}$ & $\begin{array}{l}37 \\
40 \\
39 \\
32\end{array}$ & $\begin{array}{l}51 \\
70 \\
42 \\
63\end{array}$ & $\begin{array}{r}100 \\
152 \\
94 \\
87\end{array}$ \\
\hline $\begin{array}{l}\text { Bank- en verzekeringswezen } \\
\text { Bankwezen } \\
\text { Verzekeringswezen }\end{array}$ & $\begin{array}{l}5 \\
5 \\
6\end{array}$ & $\begin{array}{l}3 \\
3 \\
3\end{array}$ & $\begin{array}{l}97 \\
98 \\
97\end{array}$ & $\begin{array}{l}66 \\
66 \\
67\end{array}$ \\
\hline $\begin{array}{l}\text { Horeca en zakelijke dienstverlening } \\
\text { Horeca } \\
\text { Zakelijke dienstverlening } \\
\text { Overige commerciële dienstverlening }\end{array}$ & $\begin{array}{r}14 \\
21 \\
10 \\
23\end{array}$ & $\begin{array}{l}24 \\
48 \\
16 \\
31\end{array}$ & $\begin{array}{l}63 \\
22 \\
79 \\
42\end{array}$ & $\begin{array}{l}81 \\
94 \\
77 \\
91\end{array}$ \\
\hline $\begin{array}{l}\text { Kwartaire diensten } \\
\text { Gezondheidszorg } \\
\text { Overige kwartaire diensten }\end{array}$ & $\begin{array}{l}13 \\
13 \\
12\end{array}$ & $\begin{array}{l}42 \\
46 \\
18\end{array}$ & $\begin{array}{l}52 \\
48 \\
77\end{array}$ & $\begin{array}{l}92 \\
94 \\
81\end{array}$ \\
\hline $\begin{array}{l}\text { Overheid en onderwijs } \\
\text { Onderwijs } \\
\text { Overheid }\end{array}$ & $\begin{array}{l}17 \\
23 \\
11\end{array}$ & $\begin{array}{l}14 \\
12 \\
15\end{array}$ & $\begin{array}{l}77 \\
66 \\
86\end{array}$ & $\begin{array}{l}84 \\
86 \\
82\end{array}$ \\
\hline Totaal & 21 & 33 & 58 & 100 \\
\hline
\end{tabular}

Psychische belasting

In tabel 4.23 wordt per bedrijfssector het percentage werkenden dat aangeeft onder hoge tijdsdruk te moeten werken weergegeven. Het werken onder hoge tijdsdruk kan ertoe leiden dat iemand op een gegeven moment zou moeten uitwijken naar een andere baan, omdat men de werkdruk niet meer aankan. Het is belangrijk dat men dan voldoende employable is om een overstap naar ander werk te kunnen maken. Omdat nog niet kan worden beschikt over gegevens omtrent de mate waarin de werkdruk toeneemt, is deze variabele vooralsnog buiten beschouwing gelaten. 
Tabel 4.23

Percentage werkenden dat met psychische belasting te maken heeft, naar bedrijfssector, 1998

Bedrijfssector

Hoge tijdsdruk

$\%$

Landbouw en visseri

Tuinbouw

Veehouderij

44

Akkerbouw, bosbouw en visserij

Voeding

Vlees- en visbewerking

Overige voedingsproducten

Drank en tabaksproducten

Chemie

Basischemie

Eindproducten chemie

Kunststofverwerking

Metaal en elektrotechniek

Basismetaal

Metaalproducten

Machine-industrie

Elektrotechniek

Transportmiddelen

Overige industrie

Textiel

Hout- en bouwmaterialen

Papier

Grafische industrie

Energie

Bouw en onroerend goed

Bouw

Exploitatie van onroerend goed

Handel en reparatie

Transport en communicatie

Scheeps- en luchtvaart

Weg-en railvervoer

Communicatie

Bank- en verzekeringswezen

Bankwezen

Verzekeringswezen

Horeca en zakelijke dienstverlening

Horeca

Zakelijke dienstverlening

Overige commerciële dienstverlening

Kwartaire diensten

Gezondheidszorg

Overige kwartaire diensten 
Tabel 4.23 (vervolg)

Percentage werkenden dat met psychische belasting te maken heeft, naar bedrijfssector, 1998

Bedrijfssector

Hoge tijdsdruk

$\%$

Overheid en onderwijs

Onderwijs

Overheid

Totaal

62

\section{Bron: CBS/ROA}

\subsection{Arbeidsmarktontwikkelingen}

De verwachte arbeidsmarktontwikkelingen worden in beeld gebracht met behulp van gegevens uit de tweejaarlijkse overzichtsrapportage De Arbeidsmarkt naar Opleiding en Beroep (ANOB) van het Researchcentrum voor Onderwijs en Arbeidsmarkt.

Tabel 4.24

Verwachte uitbreidingsvraag per bedrijfssector, 1999-2004

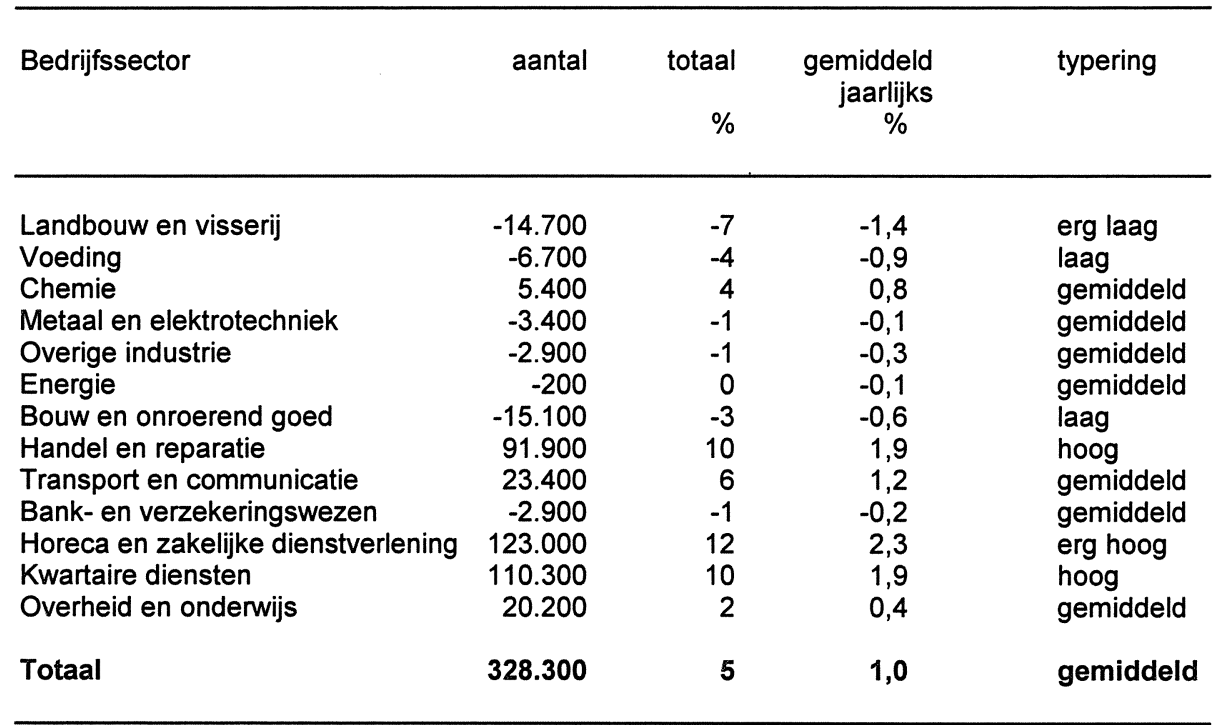

Bron: ROA

Werkgelegenheidskrimp of-groei

De ontwikkeling van de werkgelegenheid in de verschillende bedrijfssectoren wordt in beeld gebracht door te kijken naar de verwachte uitbreidingsvraag per bedrijfssector. De verwachte uitbreidingsvraag is de vraag naar nieuwe arbeidskrachten die ontstaat door groei van de werkgelegenheid. De prognoses van deze uitbreidingsvraag zijn gebaseerd op de werkgelegenheidsprognoses voor bedrijfssectoren van het Centraal Planbureau (CPB). Hierbij is uitgegaan van het zogenaamde 'behoed- 
zame scenario' van de middellange termijnprognoses van het CPB vanuit de verwachting dat de werkgelegenheidsontwikkeling de komende jaren naar verwachting zal achterblijven bij de hausse van de afgelopen jaren. In tabel 4.24 is de verwachte uitbreidingsvraag per bedrijfssector voor de periode 1999-2004 weergegeven.

\section{Uitwijkmogelijkheden}

De uitwijkmogelijkheden die werknemers op de arbeidsmarkt hebben zijn sterk afhankelijk van iemands opleidingsachtergrond en beroep. In de ANOB wordt zowel per opleidingstype als per beroepsgroep aangegeven in hoeverre iemand kan uitwijken naar een andere bedrijfssector dan die waarin men nu werkzaam is. Deze uitwijkmogelijkheden worden in beeld gebracht op basis van een spreidingsindicator, die kan worden geïnterpreteerd als het genormeerd aantal bedrijfssectoren waarin mensen in een specifieke beroepsgroep of met een specifieke opleidingsachtergrond werkzaam zijn. In tabel 4.25 is per bedrijfssector aangegeven naar hoeveel verschillende bedrijfssectoren een werknemer zou kunnen uitwijken, gegeven diens opleidingsachtergrond.

Tabel 4.25

Uitwijkmogelijkheden naar verschillende bedrijfssectoren per bedrijfssector (gemiddelde 19971998)

Akkerbouw, bosbouw en visserij

Voeding

Vlees- en visverwerking

Drank en tabaksproducten

Basischemie

Eindproducten chemie

Kunststofverwerking

Metaal- en elektrotechniek

Basismetaal

Metaalproducten

Machine-industrie

Elektrotechniek

Transportmiddelen

Overige industrie

Textiel

Hout- en bouwmaterialen

Papier

Grafische industrie 
Tabel 4.25 (vervolg)

Uitwijkmogelijkheden naar verschillende bedrijfssectoren per bedrijfssector (gemiddelde 19971998)

Bedrijfssector

Spreidingsindex

Bouw en onroerend goed

Bouw

9,04

Exploitatie van onroerend goed

Handel en reparatie

10,86

Transport en communicatie

11,17

Scheeps- en luchtvaart

11,17

Weg- en railvervoer

10,95

Communicatie

Bank- en verzekeringswezen

Bankwezen

Verzekeringswezen

Horeca en zakelijke dienstverlening

Horeca

Zakelijke dienstverlening

Overige commerciële dienstverlening

Kwartaire diensten

Gezondheidszorg

Overige kwartaire diensten

Overheid en onderwijs

Overheid

Bron: ROA

\section{Arbeidsmarktperspectieven}

In tabel 4.26 is per bedrijfssector het percentage werknemers weergegeven dat goede tot zeer goede arbeidsmarktperspectieven heeft, gegeven de opleidingsachtergrond van de betreffende werknemer. Of een werknemer goede tot zeer goede arbeidsmarktperspectieven heeft hangt af van de verwachte vraag naar en het verwachte aanbod van mensen met een bepaalde opleidingsachtergrond op de areidsarkt. Confrontatie van vraag en aanbod levert de indicator toekomstige arbeidsmarktperspectieven, de ITA (zie ook: ROA, 1999 en Van Eijs en De Grip, 1999), die de basis vormt bij het bepalen van de arbeidsmarktperspectieven van werknemers in de verschillende bedrijfssectoren. 
Tabel 4.26

Percentage werknemers (zeer) goede arbeidsmarktperspectieven gezien hun opleiding, per bedrijfssector

Bedrijfssector

Landbouw en visserij 36

Tuinbouw 26

Veehouderij 41

Akkerbouw, bosbouw en visserij 45

Voeding 23

Vlees- en visverwerking 14

Overige voedingsproducten $\quad 25$

Drank en tabaksproducten 26

Chemie

Basischemie

Eindproducten chemie

Kunststofverwerking

Metaal- en elektrotechniek 23

Basismetaal 20

Metaalproducten 16

Machine-industrie $\quad 25$

Elektrotechniek 35

Transportmiddelen 17

Overige industrie 23

Textiel 23

Hout- en bouwmaterialen 19

Papier 20

Grafische industrie $\quad 32$

Energie

Bouw en onroerend goed 17

14

Exploitatie van onroerend goed

$\begin{array}{ll}\text { Handel en reparatie } & 37\end{array}$

$\begin{array}{ll}\text { Transport en communicatie } & 40\end{array}$

Scheep- en luchtvaart $\quad 56$

Weg-en railvervoer $\quad 40$

Communicatie 32

$\begin{array}{ll}\text { Bank- en verzekeringswezen } & 48\end{array}$

Bankwezen $\quad 51$

Verzekeringswezen 43

Horeca en zakelijke dienstverlening $\quad \mathbf{5 0}$

\begin{tabular}{ll} 
Horeca & 35 \\
\hline
\end{tabular}

Zakelijke dienstverlening 54

Overige commerci\%le dienstverlening $\quad 50$

Kwartaire diensten $\quad 56$

Gezondheidszorg $\quad 54$

Overige kwartaire diensten 63 
Tabel 4.26 (vervolg)

Percentage werknemers (zeer) goede arbeidsmarktperspectieven gezien hun opleiding, per bedrijfssector

$\begin{array}{ll}\text { Bedrijfssector } & \%\end{array}$

$\begin{array}{ll}\text { Overheid en onderwijs } & 69 \\ \text { Onderwijs } & 84 \\ \text { Overheid } & 57 \\ \text { Totaal } & 43\end{array}$

\section{Bron: ROA}

\subsection{Effectueringscondities}

De effectueringscondities zoals die voor werknemers binnen bedrijfssectoren bestaan worden in beeld gebracht door allereerst gebruik te maken van de CAO-Inventarisatie zoals die door Arbeidsinspectie is uitgevoerd. Omdat deze inventarisatie enkel betrekking heeft op de employability-afspraken zoals die in de diverse CAO's zijn terug te vinden zal bovendien gebruik worden gemaakt van gegevens uit het OSA-Vraagpanel en het SZW-Werkgeverspanel.

Institutioneel en fiscaal kader

Opleiding

Afspraken in CAO's over scholing kunnen het beste in beeld worden gebracht door te kijken naar het percentage werknemers waarvoor CAO-afspraken op het gebied van scholing zijn gemaakt. Hierbij wordt gekeken naar afspraken op het gebied van algemene en functiespecifieke scholing, scholingsverlof en persoonlijke en bedrijfsopleidingsplannen. In tabel 4.27 wordt per bedrijfssector het percentage werknemers vermeld, waarvoor CAO-afspraken gelden.

Als gevolg van de sectorindeling die Arbeidsinspectie gebruikt is het vooralsnog niet mogelijk de tabel te presenteren op het niveau van de gebruikelijke dertien bedrijfssectoren. Voor een optimale invulling van de Employability Monitor zou dit echter wel gewenst zijn. 
Tabel 4.27

Percentage werknemers waarvoor $\mathrm{CAO}$-afspraken over scholing zijn gemaakt, naar bedrijfssector, 1999

\begin{tabular}{|c|c|c|c|c|c|}
\hline Bedrijfssector & $\begin{array}{c}\text { Functie } \\
\text { Gerichte } \\
\text { Scholing } \\
\%\end{array}$ & $\begin{array}{c}\text { Algemene } \\
\text { scholing } \\
\%\end{array}$ & $\begin{array}{c}\begin{array}{c}\text { Scholings- } \\
\text { verlof }\end{array} \\
\%\end{array}$ & $\begin{array}{l}\text { Persoonlijk } \\
\text { opleidings of } \\
\text { plan } \\
\%\end{array}$ & $\begin{array}{r}\text { Bedrijfs } \\
\text { pleidings } \\
\text { plan } \\
\%\end{array}$ \\
\hline $\begin{array}{l}\text { Landbouw en visserij } \\
\text { Voeding, chemie, metaal- en } \\
\text { elektrotechniek en overige industrie }\end{array}$ & 100 & 48 & 100 & 0 & 0 \\
\hline (incl. aardolieverwerking) & 99 & 7 & 41 & 12 & 49 \\
\hline $\begin{array}{l}\text { Energie (excl. Aardolieverwerking) } \\
\text { Bouw en onroerend goed (excl. }\end{array}$ & 100 & 18 & 100 & 0 & 0 \\
\hline Verhuur van onroerend goed) & 100 & 62 & 87 & 0 & 61 \\
\hline Handel en reparatie & 88 & 22 & 48 & 6 & 5 \\
\hline Transport en communicatie & 96 & 5 & 59 & 9 & 6 \\
\hline $\begin{array}{l}\text { Bank- en verzekeringswezen } \\
\text { Horeca en zakelijke dienstverlening }\end{array}$ & 100 & 0 & 73 & 98 & 73 \\
\hline (excl. overige dienstverlening) & 100 & 28 & 97 & 0 & \\
\hline Horeca & 100 & 89 & 100 & 0 & 0 \\
\hline Verhuur, zakelijke dienstverlening & 100 & 1 & 95 & 0 & 4 \\
\hline $\begin{array}{l}\text { Kwartaire diensten (incl. overige dienst } \\
\text { verlening) }\end{array}$ & 100 & 1 & 93 & 0 & 38 \\
\hline Gezondheids- en welzijnszorg & 100 & 0 & 93 & 0 & 39 \\
\hline Overige dienstverlening & 100 & 10 & 90 & 0 & 27 \\
\hline $\begin{array}{l}\text { Overheid en onderwijs } \\
\text { Openbaar bestuur, sociale }\end{array}$ & 94 & 9 & 51 & 45 & 1 \\
\hline verzekeringen & 90 & 16 & 90 & 3 & 2 \\
\hline Onderwijs & 100 & 0 & 0 & 100 & 0 \\
\hline Totaal & 97 & 17 & 69 & 14 & 21 \\
\hline
\end{tabular}

Bron: Al/Pulleman en Rojer, 2000/ROA

Naast de CAO-afspraken wordt door de Arbeidsinspectie ook gekeken in hoeverre bedrijven bij het uitvoeren van het scholingsbeleid een beroep kunnen doen op subsidie van de Arbeidsvoorzieningsorganisatie of van sectorale opleidingsfondsen (O\&O-fondsen). Op basis van gegevens uit het OSA-Vraagpanel is in tabel 4.28 per bedrijfssector het percentage bedrijven vermeld dat subsidie ontvangt.

Tabel 4.28

Percentage bedrijven dat subsidie ontvangt voor scholingskosten, naar bedrijfssector, 1997

\begin{tabular}{lc}
\hline Bedrijfssector & $\%$ \\
\hline Landbouw en visserij & 25 \\
Tuinbouw & 18 \\
Veehouderij & 40 \\
Akkerbouw, bosbouw en visserij & -
\end{tabular}


Tabel 4.28 (vervolg)

Percentage bedrijven dat subsidie ontvangt voor scholingskosten, naar bedrijfssector, 1997

\begin{tabular}{lr}
\hline Bedrijfssector & $\%$ \\
\hline Voeding & 43 \\
Vlees- en visbewerking & 45 \\
Overige voedingsproducten & 41 \\
Drank en tabaksproducten & -
\end{tabular}

$\begin{array}{ll}\text { Chemie } & 8\end{array}$

Basischemie

Eindproducten chemie

Kunststofverwerking

$\begin{array}{lr}\text { Metaal en elektrotechniek } & 65\end{array}$

$\begin{array}{ll}\text { Basismetaal } & 62\end{array}$

$\begin{array}{ll}\text { Metaalproducten } & 80\end{array}$

Machine-industrie $\quad 66$

$\begin{array}{ll}\text { Elektrotechniek } & 48\end{array}$

Transportmiddelen $\quad 55$

$\begin{array}{ll}\text { Overige industrie } & \mathbf{3 0}\end{array}$

Textiel $\quad 43$

Hout- en bouwmaterialen $\quad 31$

Papier $\quad 33$

$\begin{array}{lr}\text { Grafische industrie } & 24\end{array}$

Energie $\quad 40$

Bouw en onroerend goed $\quad 59$

Bouw $\quad 65$

$\begin{array}{ll}\text { Exploitatie van onroerend goed } & 24\end{array}$

$\begin{array}{ll}\text { Handel en reparatie } & 21\end{array}$

Transport en communicatie $\quad 19$

Scheeps- en luchtvaart $\quad 15$

Weg- en railvervoer $\quad 20$

Communicatie -

$\begin{array}{lr}\text { Bank- en verzekeringswezen } & 17\end{array}$

$\begin{array}{ll}\text { Bankwezen } & 16\end{array}$

$\begin{array}{lr}\text { Verzekeringswezen } & 14\end{array}$

$\begin{array}{ll}\text { Horeca en zakelijke dienstverlening } & 18\end{array}$

$\begin{array}{ll}\text { Horeca } & 47\end{array}$

Zakelijke dienstverlening $\quad 14$

$\begin{array}{lr}\text { Overige commerciële dienstverlening } & 27\end{array}$

Kwartaire diensten $\quad 41$

Gezondheidszorg $\quad 56$

Overige kwartaire diensten 4

Overheid en onderwijs $\quad 44$

Onderwijs $\quad 44$

$\begin{array}{ll}\text { Overheid } & 43\end{array}$

$\begin{array}{ll}\text { Totaal } & 35\end{array}$

Bron: OSA/ROA 


\section{Mobiliteit en inzetbaarheid}

Afspraken in CAO's ter stimulering van de mobiliteit en inzetbaarheid van werknemers worden in beeld gebracht door te kijken naar het percentage werknemers waarvoor CAO-afspraken zijn gemaakt over het houden van functioneringsgesprekken en over een aan de inzetbaarheid van werknemers gekoppeld beloningsbeleid. Voor deze laatste categorie afspraken wordt een onderscheid gemaakt tussen afspraken, waarbij de relatie tussen het beloningsbeleid en de inzetbaarheid expliciet aanwezig is en afspraken waarbij de relatie met employability niet direct in de CAO zelf wordt gelegd, maar deze wel impliciet aanwezig is (zie ook: Rojer en Pulleman, 2000).

Tabel 4.29

Percentage werknemers waarvoor CAO-afspraken over bevordering van mobiliteit en inzetbaarheid zijn gemaakt, naar bedrijfssector, 1999

\begin{tabular}{|c|c|c|c|}
\hline $\begin{array}{l}\text { Functionerin } \\
\text { gesprekk }\end{array}$ & $\begin{array}{l}\text { gs- } \\
\text { ren } \\
\%\end{array}$ & $\begin{array}{r}\text { Motiverend } \\
\text { beloningbeleid } \\
\%\end{array}$ & $\begin{array}{r}\text { Motiverend } \\
\text { beloningsbeleid } \\
\text { (expliciet) } \\
\%\end{array}$ \\
\hline $\begin{array}{l}\text { Landbouw en visserij } \\
\text { Voeding, chemie, metaal- en elektrotechniek en }\end{array}$ & 7 & 0 & 94 \\
\hline overige industrie (incl. aardolieverwerking) & 18 & 40 & 95 \\
\hline $\begin{array}{l}\text { Energie (excl. Aardolieverwerking) } \\
\text { Bouw en onroerend goed }\end{array}$ & 0 & 0 & 100 \\
\hline (excl. Verhuur van onroerend goed) & 0 & 0 & 87 \\
\hline Handel en reparatie & 20 & 2 & 85 \\
\hline Transport en communicatie & 36 & 29 & 96 \\
\hline $\begin{array}{l}\text { Bank- en verzekeringswezen } \\
\text { Horeca en zakelijke dienstverlening (excl. }\end{array}$ & 98 & 73 & 75 \\
\hline $\begin{array}{l}\text { overige dienstverlening) } \\
\text { Kwartaire diensten (incl. overige }\end{array}$ & 3 & 2 & 98 \\
\hline dienstverlening) & 50 & 26 & 94 \\
\hline Overheid en onderwijs & 3 & 1 & 25 \\
\hline Totaal & 21 & 15 & 81 \\
\hline
\end{tabular}

Bron: Al/Rojer en Pulleman, 2000/ROA

In tabel 4.29 wordt per bedrijfssector het percentage werknemers vermeld waarvoor CAO-afspraken op de genoemde gebieden zijn gemaakt.

Fiscale maatregelen gericht op employability

Behalve de genoemde CAO-afspraken is er ook een aantal fiscale en andere wettelijke maatregelen dat gericht is op een verbetering van de employability van werknemers. In tabel 4.30 wordt een overzicht gepresenteerd van de bestaande maatregelen. 
Tabel 4.30

(Fiscale) maatregelen ten behoeve van de employability van werknemers

Maatregel

Submaatregel

Inhoud (sub)maatregel

Doelgroep

\section{WVA}

Werkgevers kunnen op grond van de Wet Vermindering Afdracht loonbelasting en premie volksverzekeringen voor verschillende groepen werknemers de loonkosten aanzienlijk verlagen. Op grond van deze wet hoeven werkgevers minder loonbelasting en premies voor de volksverzekeringen af te dragen dan ze hebben ingehouden De WVA kent acht afdrachtverminderingen, waarvan er drie voornamelijk op werknemers zijn gericht. Dit zijn:

Afdrachtvermindering onderwijs (VO):

Werkgevers mogen korting op de loonheffing toepassen als de werknemer de beroepspraktijkvorming (BBL, voorheen: leerlingwezen) of de duale leerweg in het hoger beroepsonderwijs volgt en jonger is dan 25 jaar. Gedurende maximaal vier jaar mag een vermindering van 4.750 gulden op de aangifte loonbelasting worden toegepast mits de werknemer niet meer verdient dan $130 \%$ van het wettelijk minimum (jeugd)loon (dit toetsloon geldt niet voor werknemers van 25 jaar of ouder)

Afdrachtvermindering scholing non-profit:

Omdat de VO alleen voor profit-organisaties geldt, is met ingang van 1 januari 1999 de afdrachtvermindering scholing non-profitorganisaties ingevoerd. Deze faciliteit is bedoeld voor werkgevers die niet zijn onderworpen aan de inkomstenbelasting of vennootschapsbelasting en die kosten voor scholing hebben gemaakt ten behoeve van bij hen werkzame personen. In beginsel zal $7 \%$ van de scholingskosten in mindering mogen worden gebracht op de af te dragen loonheffing. Afhankelijk van de totale scholingskosten en de leeftijd van degene waarvoor deze gemaakt worden kan maximaal $28 \%$ van de scholingskosten in mindering worden gebracht op de loonheffing. Met ingang van 2001 geldt een extra afdrachtvermindering van $7 \%$ van bepaalde scholingskosten (zie scholingsaftrek).

Werkgevers

Profit

Werkgevers non-profit 
Tabel 4.30 (vervolg)

(Fiscale) maatregelen ten behoeve van de employability van werknemers

Maatregel

Submaatregel

Inhoud (sub)maatregel

Doelgroep

Afdrachtvermindering kinderopvang:

$30 \%$ van de kosten die een werkgever maakt voor kinderopvang van de kinderen van werknemers is aftrekbaar van de loonbelasting/ premies volksverzekeringen. Eigen bijdragen van de werknemer worden van het bedrag waarover de vermindering wordt berekend afgetrokken. Het gaat hierbij om kinderopvang voor eigen, stief- en/ of pleegkinderen jonger dan 13 jaar.

Van de overige vijf afdrachtverminderingsregelingen worden er drie besproken in tabel 5.20 (SPAK, Doorstroom-SPAK en de afdrachtvermindering langdurig werklozen). De overige twee regelingen: afdrachtvermindering speur- en ontwikkelingswerk en afdrachtvermindering zeevaart, houden geen verband met de employability van werknemers en/of niet-werkenden en vallen dus buiten de Employability Monitor.

Afdrachtvermindering kinderopvang vennootschapsbelasting $\mathrm{Na}$ aftrek van de eigen bijdrage van de werknemer en de $30 \%$ afdrachtvermindering op loonbelasting $c . q$ premies volksverzekeringen in het kader WVA, kan de werkgever nog $37 \%$ van de resterende kosten aftrekken van de winst waarover vennootschapsbelasting verschuldigd is.

Aftrek kosten kinderopvang inkomstenbelasting

Werknemers kunnen de kosten voor kinderopvang volledig als buitengewone lasten aftrekken van hun belastbaar inkomen.

Scholingsaftrek voor de profitsector

Bedrijven mogen $20 \%$ van de scholingskosten extra aftrekken van de fiscale winst indien de scholingskosten niet meer dan fl. 250.000,bedragen. Voor scholing van personen ouder dan 40 wordt een aanvullende aftrek van 40\% ingevoerd. Met ingang van 2001 geldt een extra aftrek van $20 \%$ van bepaalde scholingskosten. Het gaat hierbij om scholingskosten voor werknemers die een middelbare beroepsopleiding tot een bepaald niveau (niveau 2) volgen. Opleidingen die daarvoor in aanmerking komen, staan in het zogenoemde bestaande CREBO-register van het Ministerie van OC en W. De verruiming is ook van toepassing op beroepsgerichte taalopleidingen of cursussen.

Willekeurige afschrijving ARBO investeringen(FARBO)

Investeringen in bedrijfsmiddelen ter verbetering van arbeidsomstandigheden kunnen willekeurig worden afgeschreven. De lijst met gefacilieerde bedrijfsmiddelen wordt jaarlijks -mede aan de hand van voorstellen van bedrijven- samengesteld.

Werkgevers

Werkgevers

(BV, NV)

Werknemers

Werkgevers

Werkgevers 
Tabel 4.30 (vervolg)

(Fiscale) maatregelen ten behoeve van de employability van werknemers

Maatregel

Submaatregel

Inhoud (sub)maatregel

Doelgroep

Verlofspaarregeling

Op basis van deze regeling kunnen aanspraken ingevolge een tussen een werkgever en werknemer overeengekomen verlofspaarregeling onder bepaalde voorwaarden worden vrijgesteld en de uitkeringen worden belast. De regeling biedt de mogelijkheid om in een jaar $10 \%$ van het loon van dat jaar of een daarmee corresponderend aantal verlofuren naar een tijdstip in de toekomst te verschuiven. De regeling zal naar verwachting per 1 januari 2001 van kracht worden.

\section{Aftrek studiekosten}

Individuele werknemers kunnen hun scholingskosten aftrekken van de belasting. Uitgaven ter zake van opleiding of studie voor een beroep zijn aftrekbaar als buitengewone lasten voor zover zij meer bedragen dan fl. 800 ,- of, indien dit minder is, $2 \%$ van het onzuiver inkomen.

Wet financiering loopbaanonderbreking

Deze niet-fiscale maatregel biedt de mogelijkheid tot financiële ondersteuning voor werknemers die verlof opnemen voor zorg (ouderschapsverlof/adoptieverlof) of studie. Door de wet worden werknemers gestimuleerd verlof op te nemen, kunnen werklozen en herintreders werkervaring opdoen en wordt de reïntegratie van arbeidsgehandicapten bevorderd. Werknemers kunnen voor een periode van minimaal 2 en maximaal 6 maanden tot een bedrag van fl. 960,- bruto per maand aan financiële steun ontvangen. Een voorwaarde is wel dat de loopbaanonderbreker vervangen wordt door iemand die een werkloosheids-, bijstands-, arbeidsongeschiktheids- of algemene nabestaandenuitkering heeft. Ook kunnen iemand met een arbeidshandicap of een herintreder als vervanger optreden, mits zij ingeschreven staan bij het arbeidsbureau. Deze voorwaarde geldt overigens niet wanneer er sprake is van palliatief verlof (verlof voor het bijstaan van ongeneeslijk zieke naasten).

Werkgevers/werknemers

Werknemers

Werknemers 


\section{Faciliteiten}

Faciliteiten gericht op mobiliteit en inzetbaarheid

Om de mobiliteits- en inzetbaarheidsfaciliteiten die de werknemer in verschillende bedrijfssectoren worden geboden in beeld te brengen is gebruik gemaakt van twee verschillende databronnen, namelijk het OSA-Vraagpanel en het SZW-Werkgeverspanel. In tabel 4.31 wordt allereerst een beeld gegeven van de mate waarin bedrijven hun werknemers faciliteiten bieden die hun inzetbaarheid c.q. mobiliteit bevorderen. De gegevens die in tabel 4.31 zijn weergegeven zijn afkomstig uit het SZW-Werkgeverspanel. In het panel wordt aan bedrijven gevraagd of zij systematisch aandacht besteden aan de inzetbaarheid van werknemers en of zij ter bevordering van de inzetbaarheid van personeel beoordelingsgesprekken voeren. Bovendien wordt gevraagd of bedrijven bij een te geringe inzetbaarheid mensen over- of herplaatsen of outplacement toepassen. In de laatste kolom van tabel 4.31 wordt een indexcijfer gepresenteerd. Dit maakt het mogelijk in één oogopslag te zien binnen welke bedrijfssectoren de aanwezigheid van de genoemde mobiliteits- en inzetbaarheidsfaciliteiten in vergelijking met andere bedrijfssectoren mogelijk tekort schieten.

In tabel 4.32 wordt met gebruikmaking van het OSA-Vraagpanel bovendien inzicht gegeven in de mate waarin bedrijfssectoren zich bezighouden met beleid op het gebied van functieroulatie, personeelsplanning en loopbaanontwikkeling. Personeelsplanning en loopbaanontwikkeling zijn beiden gericht op de sturing van personeelsstromen binnen de organisatie en eventueel ook daarbuiten en kunnen dus worden opgevat als mobiliteitsfaciliteiten. Functieroulatie wordt door bedrijven toegepast om de inzetbaarheid van het personeel te vergroten, waarmee het voeren van beleid op het gebied van functieroulatie duidt op de aanwezigheid van faciliteiten gericht op inzetbaarheid. In tabel 4.32 wordt het percentage bedrijven per bedrijfssector gepresenteerd dat aangeeft beleid te voeren op het gebied van functieroulatie, personeelsplanning of loopbaanontwikkeling. In de laatste kolom van de tabel is d.m.v. indexcijfers direct te zien binnen welke bedrijfssectoren relatief veel faciliteiten op het gebied van mobiliteit en inzetbaarheid worden geboden. 


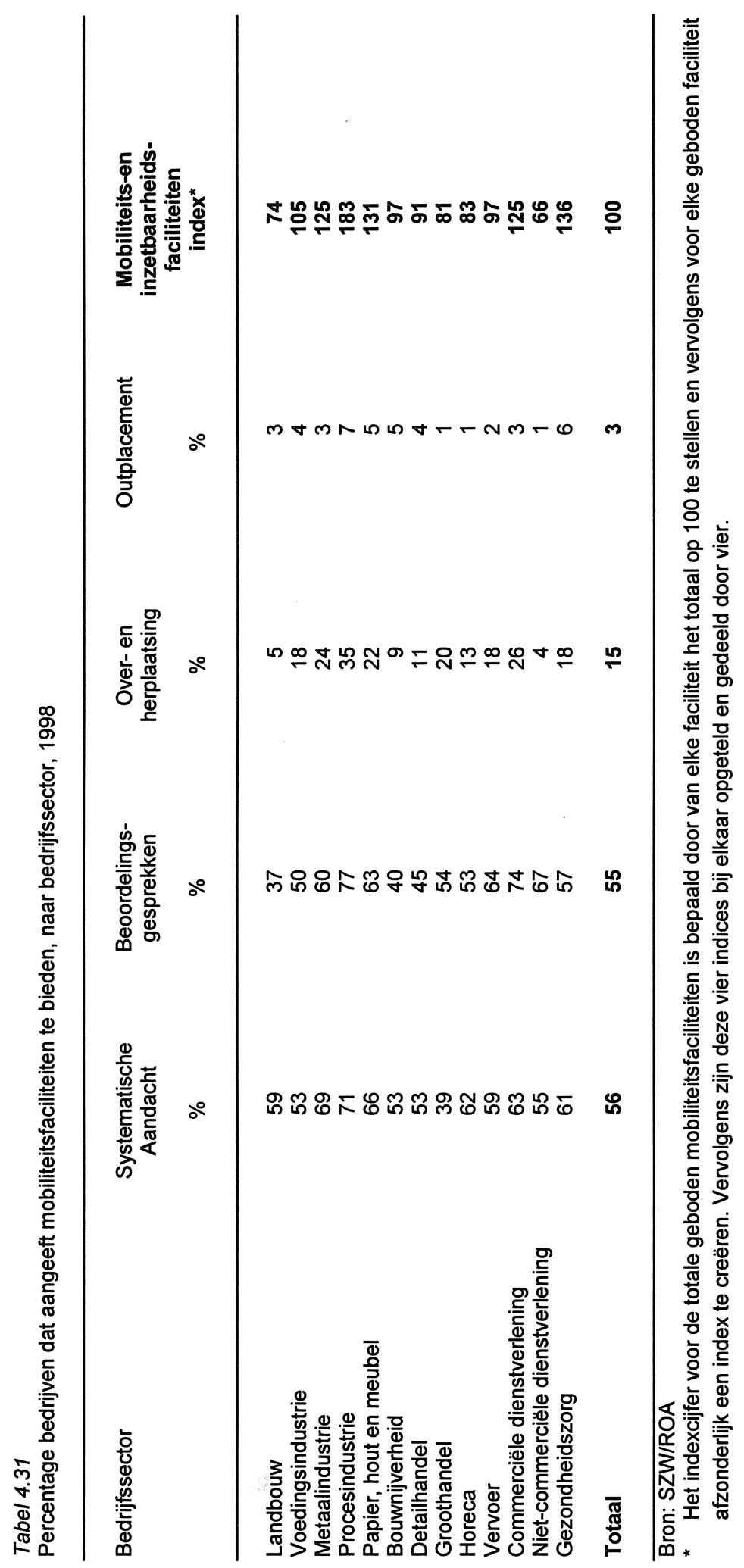


Tabel 4.32

Percentage bedrijven dat beleid voert op het gebied van functieroulatie, personeelsplanning en loopbaanontwikkeling, 1997

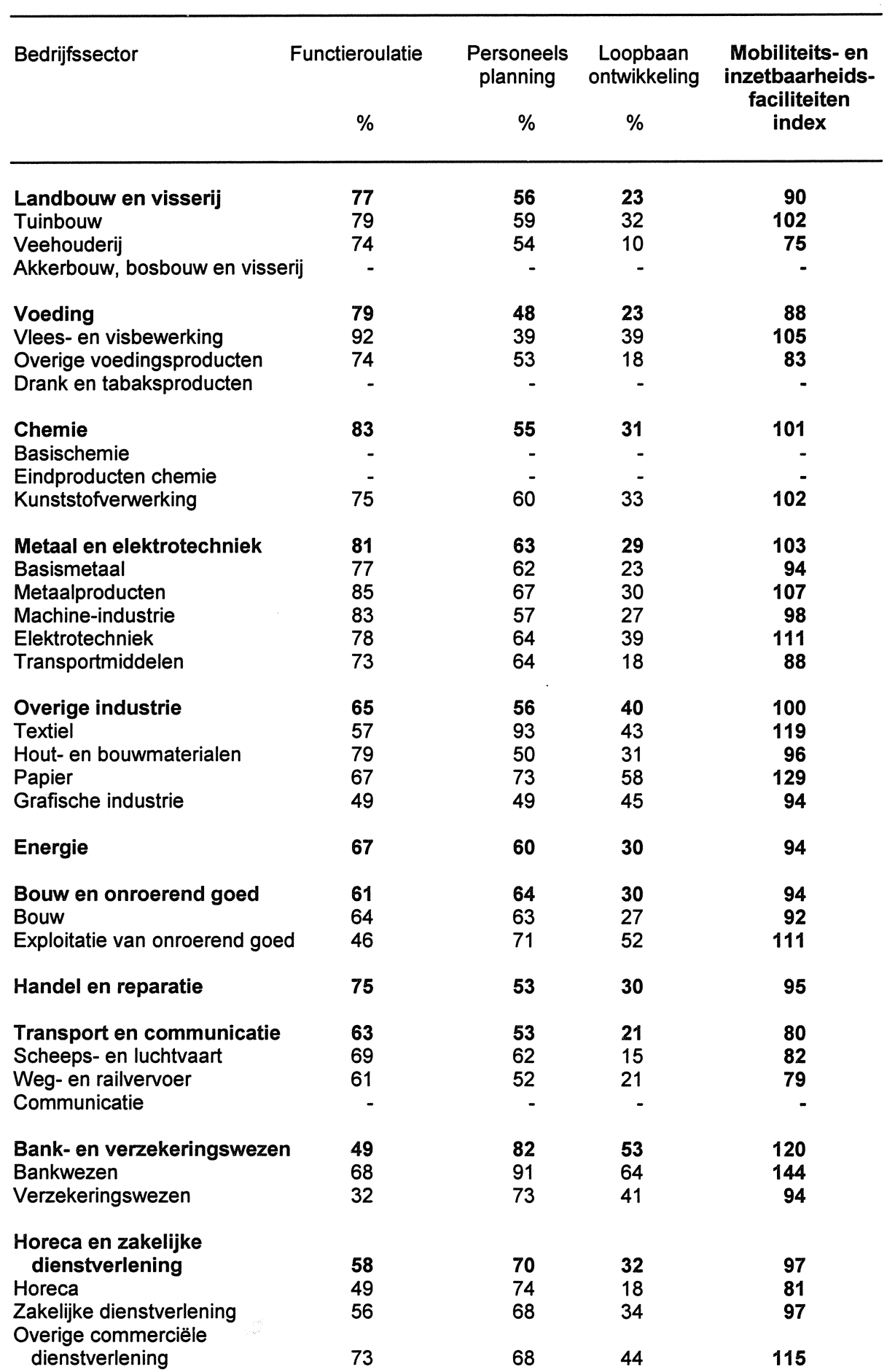


Tabel 4.32 (vervolg)

Percentage bedrijven dat beleid voert op het gebied van functieroulatie, personeelsplanning en loopbaanontwikkeling, 1997

\begin{tabular}{lcccc}
\hline Bedrijfssector & Functieroulatie & $\begin{array}{c}\text { Personeels } \\
\text { Planning }\end{array}$ & $\begin{array}{c}\text { Loopbaan } \\
\text { ontwikkeling }\end{array}$ & $\begin{array}{c}\text { Mobiliteits-en } \\
\text { inzetbaarheids- } \\
\text { faciliteiten } \\
\text { index }\end{array}$ \\
\hline Kwartaire diensten & 5 & $\%$ & $\%$ & 107 \\
Gezondheidszorg & 55 & 76 & 41 & 112 \\
Overige kwartaire diensten & 52 & 82 & 42 & 92 \\
Overheid en onderwijs & 57 & 59 & 36 & 130 \\
Onderwijs & 59 & 86 & 57 & 130 \\
Overheid & 44 & 79 & 57 & 125 \\
Totaal & 66 & 64 & 34 & 100 \\
\hline
\end{tabular}

Bron: OSA

De totaalindex is bepaald door de percentages in iedere kolom te indexeren, de gevonden indexcijfers op te tellen en de som te delen door drie. Wanneer een bedrijfssector een score heeft die hoger is dan 100, dan worden voldoende faciliteiten geboden

Opleidingsfaciliteiten

In tabel 4.33 wordt met gebruikmaking van data uit het SZW-Werkgeverspanel weergegeven in hoeverre bedrijfssectoren opleidingsfaciliteiten bieden. Hierbij wordt een vijftal vormen van training onderscheiden, te weten:

- vaktechnische training;

- beroepsvaardigheidstraining;

- motivatietraining;

- weerbaarheids- en sociale vaardigheidstraining;

- flexibiliteitstraining gericht op veranderingsgezindheid.

Behalve de mate waarin bedrijven aangeven opleidingsfaciliteiten te bieden is het ook van belang te weten in hoeverre bedrijven dat kunnen vanuit hun eigen opleidingscentrum. Het beschikken over een eigen opleidingscentrum maakt het immers aanzienlijk gemakkelijker voor bedrijven om hun personeel opleidingen aan te bieden. Vooralsnog is het niet mogelijk de aanwezigheid van een opleidingscentrum per bedrijfssector in beeld te brengen, omdat geen enkele databron deze informatie levert. Voor de toekomst kan het Continuing Vocational Training Survey hiervoor echter geschikt zijn. Bovendien kan voor informatie omtrent interne opleidingscentra mogelijk een vraag worden opgenomen in een volgende golf van het OSA-Vraagpanel.

Als gevolg van de door SZW gebruikte sectorindeling is het vooralsnog niet mogelijk de aanwezigheid van opleidingsfaciliteiten in beeld te brengen voor 35 bedrijfsklassen. 


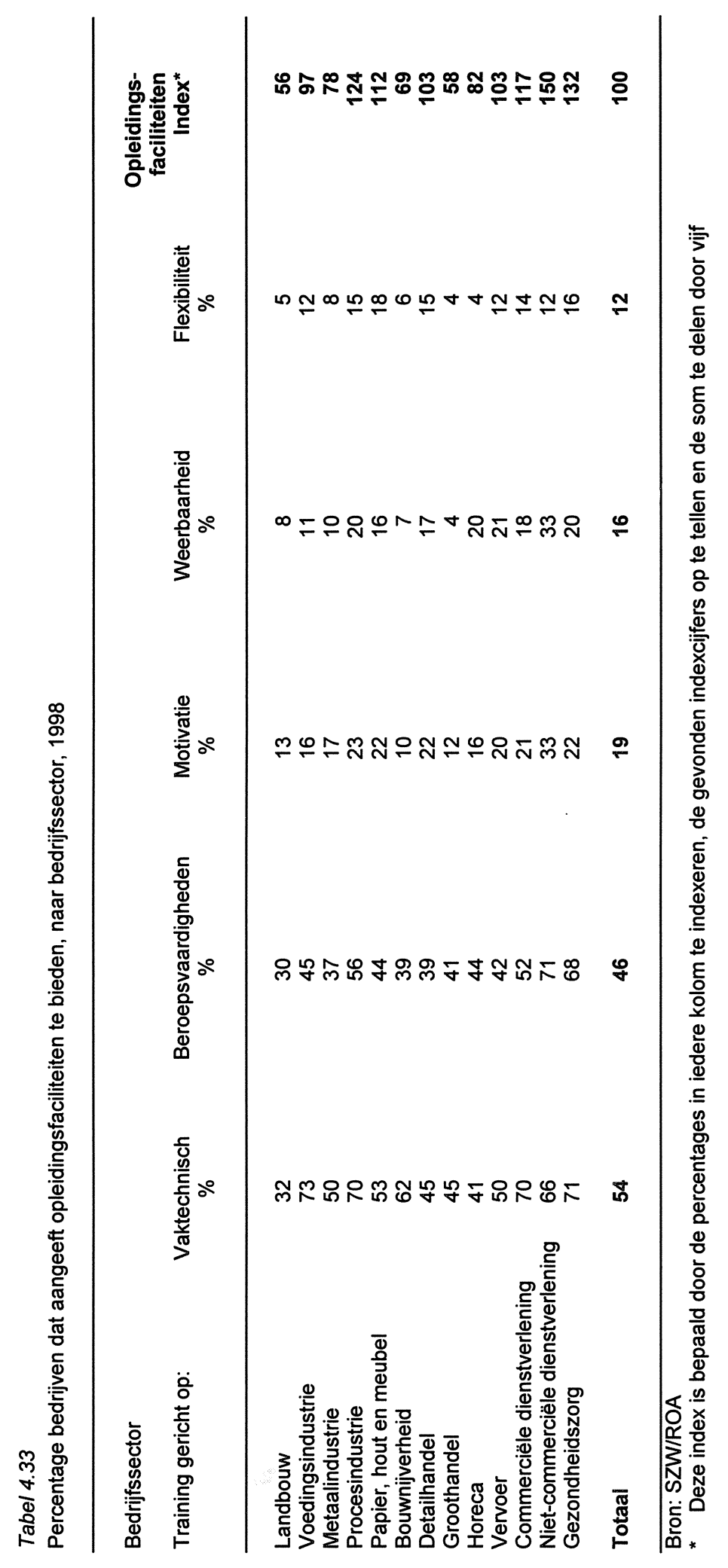


Andere faciliteiten

Met gebruikmaking van data uit het OSA-Vraagpanel wordt in tabel 4.34 inzicht verschaft in de mate waarin bedrijven andere faciliteiten bieden ter ondersteuning van de employability van werknemers. De faciliteiten die hierbij aan de orde komen zijn het al dan niet aanwezig zijn van faciliteiten ter kinderopvang, het al dan niet voeren van leeftijdsbewust personeelsbeleid en ARBO-beleid en het structureel verzorgen van verzuimbegeleiding.

Tabel 4.34

Percentage bedrijven dat andere faciliteiten biedt ter bevordering van de employability, naar bedrijfssector, 1997

\begin{tabular}{|c|c|c|c|}
\hline \multirow[t]{2}{*}{ Bedrijfssector } & \multicolumn{3}{|c|}{ Faciliteiten op het gebied van: } \\
\hline & $\begin{array}{l}\text { Leeftijdsbewust } \\
\text { Personeelsbeleid } \\
\%\end{array}$ & $\begin{array}{c}\text { Kinderopvang } \\
\%\end{array}$ & $\begin{array}{c}\text { ARBO/verzuim } \\
\%\end{array}$ \\
\hline Landbouw en visserij & 31 & 0 & 68 \\
\hline Tuinbouw & 42 & 0 & 72 \\
\hline Veehouderij & 6 & 0 & 61 \\
\hline Akkerbouw, bosbouw en visserij & - & - & - \\
\hline Voeding & 27 & 9 & 83 \\
\hline Vlees-en visbewerking & 42 & 23 & 100 \\
\hline Overige voedingsproducten & 16 & 3 & 77 \\
\hline Drank en tabaksproducten & - & - & - \\
\hline Chemie & 55 & 10 & 79 \\
\hline Basischemie & - & - & - \\
\hline Eindproducten chemie & - & - & - \\
\hline Kunststofverwerking & 50 & 7 & 60 \\
\hline Metaal en elektrotechniek & 41 & 7 & 86 \\
\hline Basismetaal & - & 15 & 100 \\
\hline Metaalproducten & 53 & 7 & 85 \\
\hline Machine-industrie & 39 & 7 & 98 \\
\hline Elektrotechniek & 28 & 7 & 74 \\
\hline Transportmiddelen & - & 9 & 64 \\
\hline Overige industrie & 44 & 15 & 88 \\
\hline Textiel & 54 & 14 & 93 \\
\hline Hout- en bouwmaterialen & 46 & 8 & 81 \\
\hline Papier & 45 & 17 & 91 \\
\hline Grafische industrie & 38 & 23 & 94 \\
\hline Energie & - & 30 & 50 \\
\hline Bouw en onroerend goed & 41 & 10 & 87 \\
\hline Bouw & 41 & 6 & 86 \\
\hline Exploitatie van onroerend goed & 41 & 38 & 93 \\
\hline Handel en reparatie & 26 & 7 & 80 \\
\hline
\end{tabular}


Tabel 4.34 (vervolg)

Percentage bedrijven dat andere faciliteiten biedt ter bevordering van de employability, naar bedrijfssector, 1997

\begin{tabular}{|c|c|c|c|}
\hline \multirow[t]{2}{*}{ Bedrijfssector } & \multicolumn{3}{|c|}{ Faciliteiten op het gebied van: } \\
\hline & $\begin{array}{c}\text { Leeftijdsbewust } \\
\text { Personeelsbeleid } \\
\%\end{array}$ & $\begin{array}{c}\text { Kinderopvang } \\
\%\end{array}$ & $\begin{array}{c}\text { ARBO/verzuim } \\
\%\end{array}$ \\
\hline Transport en communicatie & 43 & 5 & 81 \\
\hline Scheeps- en luchtvaart & - & 0 & 85 \\
\hline Weg-en railvervoer & 44 & 5 & 81 \\
\hline Communicatie & - & - & - \\
\hline Bank- en verzekeringswezen & 30 & 49 & 86 \\
\hline Bankwezen & 41 & 68 & 100 \\
\hline Verzekeringswezen & 13 & 32 & 73 \\
\hline Horeca en zakelijke dienstverlening & 33 & 13 & 74 \\
\hline Horeca & 29 & 9 & 67 \\
\hline Zakelijke dienstverlening & 34 & 16 & 76 \\
\hline Overige commerciële dienstverlening & 42 & 13 & 80 \\
\hline Kwartaire diensten & 56 & 48 & 89 \\
\hline Gezondheidszorg & 62 & 59 & 96 \\
\hline Overige kwartaire diensten & 30 & 16 & 72 \\
\hline Overheid en onderwijs & 70 & 26 & 95 \\
\hline Onderwijs & 71 & 21 & 95 \\
\hline Overheid & 63 & 68 & 100 \\
\hline Totaal & 40 & 14 & 83 \\
\hline
\end{tabular}

Bron: OSA/ROA

Tabel 4.35

Percentage bedrijven dat langdurig zorgverlof (zeer) terecht vindt, per bedrijfssector, 1999

Bedrijfssector SZW (ROA indeling)

Landbouw (Landbouw en visserij)

Metaalindustrie (Metaal- en elektrotechniek)

Voedingsindustrie (Voeding)

Procesindustrie (Chemie)

Papier, hout en meubel (Overige industrie)

Bouwnijverheid (Bouw en onroerend goed)

Detailhandel (Handel en reparatie)

Groothandel (Handel en reparatie)

Horeca (Horeca en zakelijke dienstverlening)

Vervoer (Transport en communicatie)

Commerciële dienstverlening (Horeca en zakelijke dienstverlening)

Niet-commerciële dienstverlening (Kwartaire diensten)

Gezondheidszorg (Overheid en Onderwijs)

Totaal

Bron: SZW 
In tabel 4.35 wordt ten slotte het percentage bedrijven per sector weergegeven dat positief staat tegenover langdurig zorgverlof. Een dergelijke houding kan bijvoorbeeld vrouwen met jonge kinderen of werknemers met een zieke partner of een ziek familielid stimuleren om in dienst te treden of in dienst te blijven.

\section{Communicatie}

Inzicht in toekomstperspectief

Op basis van het OSA-Aanbodpanel wordt per bedrifssector het percentage werknemers vermeld dat aangeeft een zekere mate van inzicht te hebben in het eigen toekomstperspectief. In tabel 4.36 wordt het percentage werknemers vermeld dat op de vraag zich voor te stellen hoe de arbeidsmarktsituatie er over 5 jaar uitziet een ander antwoord geeft dan 'weet niet'.

Tabel 4.36

Percentage werknemers dat aangeeft inzicht te hebben in het eigen toekomstperspectief, naar bedrijfssector, 1998

Bedrijfssector

Landbouw en visserij

Tuinbouw

Veehouderij

Akkerbouw, bosbouw en visserij

Voeding

Vlees- en visbewerking

Overige voedingsproducten

Drank en tabaksproducten

Chemie

Basischemie

Eindproducten chemie

Kunststofverwerking

Metaal en elektrotechniek

Basismetaal

100

Metaalproducten

90

Machine-industrie

100

Transportmiddelen

Overige industrie

Textiel

Hout- en bouwmaterialen

Papier

Grafische industrie

Energie

Bouw en onroerend goed

Bouw

Exploitatie van onroerend goed 
Tabel 4.36 (vervolg)

Percentage werknemers dat aangeeft inzicht te hebben in het eigen toekomstperspectief, naar bedrijfssector, 1998

\begin{tabular}{lc}
\hline Bedrifssector & $\%$ \\
\hline Transport en communicatie & \\
Scheeps- en luchtvaart & 94 \\
Weg- en railvervoer & 83 \\
Communicatie & 94 \\
Bank- en verzekeringswezen & 96 \\
Bankwezen & 95 \\
Verzekeringswezen & 95 \\
Horeca en zakelijke dienstverlening & 95 \\
Horeca & 94 \\
Zakelijke dienstverlening & 86 \\
Overige commerciële dienstverlening & 95 \\
Kwartaire diensten & 94 \\
Gezondheidszorg & 93 \\
Overige kwartaire diensten & 93 \\
Overheid en onderwijs & 88 \\
Onderwijs & \\
Overheid & 94 \\
Totaal & 95 \\
& 94 \\
\hline Bron: OSAROA & 94 \\
\hline
\end{tabular}

Bron: OSA/ROA

Voor de overige communicatievariabelen zijn vooralsnog geen data voorhanden. 


\section{Een eerste invulling van de Employability Monitor: niet-werkenden}

De employability van de niet-werkenden spitst zich, zoals in hoofdstuk 3 werd aangegeven, toe op de intredekans op de arbeidsmarkt. Omdat voor niet-werkenden niet zozeer de kans op behoud van werk als wel de kans op het verkrijgen van werk centraal staat, moet de employability van niet-werkenden ook op een andere manier in beeld worden gebracht dan de employability van werknemers. In dit hoofdstuk zal een eerste invulling van de Employability Monitor voor niet-werkenden worden gegeven. Zoals in hoofdstuk 2 werd aangegeven, is geprobeerd bij de monitoring van de employability van niet-werkenden vier verschillende groepen te onderscheiden, te weten:

- niet-werkende werkzoekenden;

- niet-participerenden met een werkende partner;

- niet-participerenden met een bepaalde arbeidshandicap;

- niet-participerende vijftigplussers.

Helaas is het als gevolg van beperkingen in de gebruikte databronnen niet altijd mogelijk de niet-werkenden naar de vier genoemde groepen te verbijzonderen. Met name de verbijzondering naar niet-participerenden met een werkende partner is niet mogelijk met de beschikbare databronnen. In deze gevallen is ervoor gekozen binnen de groep niet-werkenden in eerste instantie een onderscheid te maken naar niet-werkende werkzoekenden en niet-participerenden ('niet-werkende niet werkzoekenden' ). Wanneer ook dat onderscheid niet te maken is, kan slechts gekeken worden naar de gehele groep niet-werkenden. In enkele gevallen worden alleen cijfers vermeld voor de groep niet-werkende werkzoekenden. Dit laatste geldt met name voor aspecten die betrekking hebben op het zoekgedrag.

De gegevens die in dit hoofdstuk worden gepresenteerd zijn verbijzonderd naar 5 opleidingsniveaus.

De indeling van het hoofdstuk is min of meer vergelijkbaar met die van hoofdstuk 4 . In paragraaf 5.1 wordt gekeken naar de individuele employability van niet-werkenden. In paragraaf 5.2 wordt een beeld gegeven van de korte termijn arbeidsmarktperspectieven en de uitwijkmogelijkheden van niet-werkenden en in paragraaf 5.3 worden ten slotte de effectueringscondities voor de employability van de verschillende groepen niet-werkenden in kaart gebracht.

\subsection{Individuele employability van niet-werkenden}

De individuele employability van niet-werkenden kan het beste in beeld worden gebracht door gebruik te maken van de Enquête Beroepsbevolking, het OSAAanbodpanel en het Hoe Zoeken Werkzoekenden bestand. Als aanvullende bron is gebruik gemaakt van de International Adult Literacy Survey (IALS). Nadeel van het gebruik van het OSA-Aanbodpanel is dat het niet goed mogelijk is het gewenste 
onderscheid naar de verschillende groepen niet-werkenden te maken. In die gevallen dat een nader onderscheid wel te maken is, blijkt het aantal respondenten veelal te gering om enigszins betrouwbare uitspraken te kunnen doen. Het gebruik van de EBB voorkomt dergelijke problemen. Er is dan ook zoveel mogelijk van deze laatste bron gebruikt gemaakt.

Kanttekening bij het gebruik van data afkomstig uit het $\mathrm{HZW}$-bestand is dat alleen informatie wordt verzameld over mensen die op zoek zijn naar werk, mensen die het laatste jaar werk hebben gevonden en mensen die ingeschreven staan bij arbeidsbureaus/CWI's of daar recent ingeschreven hebben gestaan. De informatie over nietparticiperenden die in dit hoofdstuk is opgenomen en die afkomstig is uit het HZWbestand heeft daardoor alleen betrekking op niet-participerenden die ingeschreven staan of hebben gestaan bij arbeidsbureaus/CWI's. Dat duidt erop dat deze categorie niet-werkenden in elk geval ooit gedacht heeft aan intrede op de arbeidsmarkt, waardoor het beeld van de intredekansen voor niet-participerenden wat rooskleuriger zal zijn dan het in werkelijkheid is. Zeker waar het de variabelen betreft die betrekking hebben op de bereidheid om in te treden.

\section{Vermogen}

Om het employability-vermogen van niet-werkenden in beeld te brengen moeten allereerst de kwalificaties van de niet-werkenden worden vastgesteld. Kwalificaties worden, net als bij de werknemers, bepaald aan de hand van gegevens over de hoogst genoten opleiding. Vervolgens wordt ook voor de niet-werkenden het competentieniveau bepaald op basis van de lees-, schrijf-, spreek-, en rekenvaardigheid. Behalve naar deze kwalificaties wordt ook gekeken naar de periode waarin een nietwerkende geen betaald werk heeft verricht. De periode van inactiviteit bepaalt immers voor een belangrijk deel de directe inzetbaarheid van niet-werkenden. Wanneer iemand al geruime tijd niet actief is geweest op de arbeidsmarkt, als gevolg van bijvoorbeeld zorgtaken of ziekte, dan zijn de kwalificaties waarover hij of zij beschikt waarschijnlijk verouderd. In dit kader wordt ook wel van 'atrofie' gesproken (zie ook: De Grip c.s., 1990). Het beeld van het employability-vermogen van niet-werkenden kan worden aangevuld door te kijken naar hun mobiliteitsvermogen, opleidingsvermogen en hun vermogen zich breed in te zetten.

Kwalificaties: Initiële en vervolgopleiding

Om een beeld te krijgen van het opleidingsniveau van de verschillende groepen nietwerkenden is in tabel 5.1 als indicator de hoogst voltooide opleiding van niet-werkenden gebruikt. De gepresenteerde data komen uit het OSA-Aanbodpanel. In de laatste kolom van tabel 5.1 wordt het percentage niet-werkenden aangegeven met een goede 'startkwalificatie' voor de arbeidsmarkt, dat wil zeggen degenen met een HAVONWO/MBO opleiding of hoger. 
Tabel 5.1

Opleidingsniveau van niet-werkenden, 1998

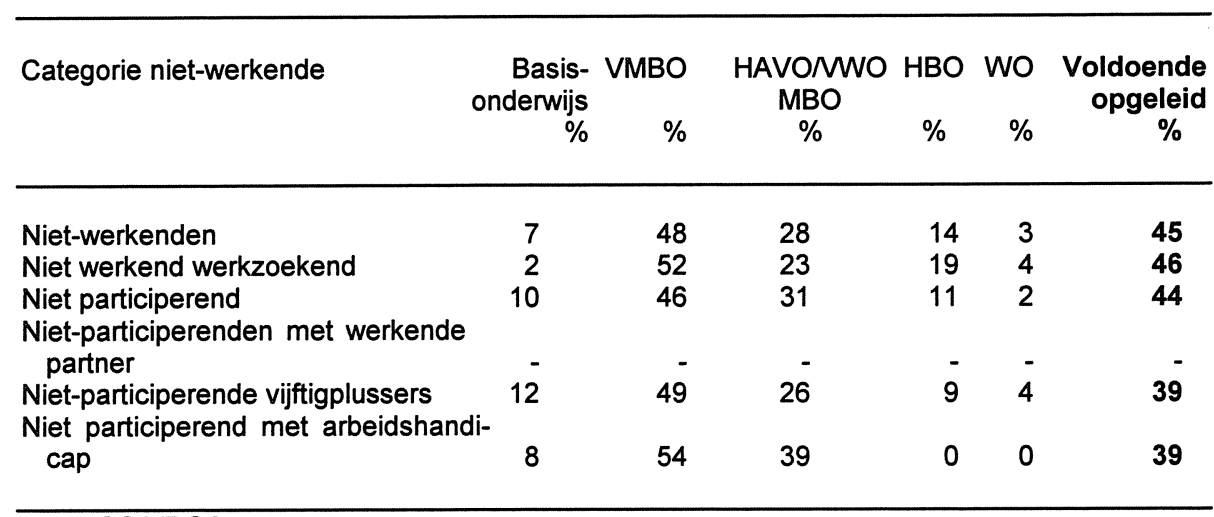

Bron: OSA/ROA

Kwalificaties: Competenties

De competenties van niet-werkenden worden bepaald aan de hand van de beschikbare gegevens uit de IALS. Evenals de werknemers zijn de niet-werkenden in dit onderzoek op een drietal terreinen getest, waarbij telkens een viertal competentieniveaus wordt onderscheiden (zie hoofdstuk 4). Omdat in de IALS-data geen onderscheid wordt gemaakt tussen de verschillende groepen niet-werkenden, wordt in de tabellen 5.2 tot en met 5.5 alleen het competentieniveau weergegeven van de totale groep niet-werkenden, verbijzonderd naar opleidingsniveau. In de laatste kolom van de tabellen 5.2 tot en met 5.4 wordt aangegeven welk percentage van de niet-werkenden met een bepaalde opleidingsachtergrond als 'voldoende competent' kan worden beschouwd. Het betreft hier de niet-werkenden die minimaal competentieniveau 3 hebben en dus voldoen aan de minimumeisen. In tabel 5.5 wordt per opleidingsachtergrond het percentage van de niet-werkenden weergegeven dat op alle gemeten competenties minimaal niveau 3 heeft.

Tabel 5.2

Competentieniveau van niet-werkenden om geschreven informatie te begrijpen, naar opleidingsniveau, 1994

\begin{tabular}{|c|c|c|c|c|c|}
\hline Opleidingsniveau & $\begin{array}{r}\text { Niveau } \\
1 \\
\%\end{array}$ & $\begin{array}{r}\text { Niveau } \\
2 \\
\%\end{array}$ & $\begin{array}{r}\text { Niveau } \\
3 \\
\%\end{array}$ & $\begin{array}{r}\text { Niveau } \\
4 / 5 \\
\%\end{array}$ & $\begin{array}{c}\text { Voldoende } \\
\text { Competent } \\
\%\end{array}$ \\
\hline $\begin{array}{l}\text { Basisonderwijs } \\
\text { V(M)BO (incl. MAVO) } \\
\text { HAVOMWO en MBO } \\
\text { HBONO }\end{array}$ & $\begin{array}{r}46 \\
14 \\
5 \\
4\end{array}$ & $\begin{array}{l}40 \\
48 \\
29 \\
17\end{array}$ & $\begin{array}{l}12 \\
32 \\
52 \\
53\end{array}$ & $\begin{array}{r}2 \\
6 \\
15 \\
26\end{array}$ & $\begin{array}{l}14 \\
38 \\
66 \\
79\end{array}$ \\
\hline Totaal & 16 & 37 & 37 & 10 & 47 \\
\hline
\end{tabular}

Bron: OECD/ROA 
Tabel 5.3

Competentieniveau van niet-werkenden om informatie te lokaliseren en te gebruiken, naar opleidingsniveau, 1994

\begin{tabular}{|c|c|c|c|c|c|}
\hline Opleidingsniveau & $\begin{array}{r}\text { Niveau } \\
1 \\
\%\end{array}$ & $\begin{array}{r}\text { Niveau } \\
2 \\
\%\end{array}$ & $\begin{array}{r}\text { Niveau } \\
3 \\
\%\end{array}$ & $\begin{array}{r}\text { Niveau } \\
4 / 5 \\
\%\end{array}$ & $\begin{array}{c}\text { Voldoende } \\
\text { Competent } \\
\%\end{array}$ \\
\hline $\begin{array}{l}\text { Basisonderwijs } \\
\text { V(M)BO (incl. MAVO) } \\
\text { HAVONWO en MBO } \\
\text { HBOMO }\end{array}$ & $\begin{array}{r}51 \\
17 \\
8 \\
4\end{array}$ & $\begin{array}{l}30 \\
42 \\
27 \\
22\end{array}$ & $\begin{array}{l}17 \\
35 \\
50 \\
57\end{array}$ & $\begin{array}{r}2 \\
6 \\
16 \\
17\end{array}$ & $\begin{array}{l}18 \\
41 \\
66 \\
74\end{array}$ \\
\hline Totaal & 19 & 33 & 39 & 10 & 48 \\
\hline
\end{tabular}

Bron: OECD/ROA

\section{Tabel 5.4}

Competentieniveau van niet-werkenden om wiskunde toe te passen, naar opleidingsniveau, 1994

\begin{tabular}{|c|c|c|c|c|c|}
\hline Opleidingsniveau & $\begin{array}{r}\text { Niveau } \\
1 \\
\%\end{array}$ & $\begin{array}{r}\text { Niveau } \\
2 \\
\%\end{array}$ & $\begin{array}{r}\text { Niveau } \\
3 \\
\%\end{array}$ & $\begin{array}{r}\text { Niveau } \\
4 / 5 \\
\%\end{array}$ & $\begin{array}{c}\text { Voldoende } \\
\text { Competent } \\
\%\end{array}$ \\
\hline $\begin{array}{l}\text { Basisonderwijs } \\
\text { V(M)BO (incl. MAVO) } \\
\text { HAVONWO en MBO } \\
\text { HBOMO }\end{array}$ & $\begin{array}{r}51 \\
18 \\
8 \\
4\end{array}$ & $\begin{array}{l}30 \\
45 \\
33 \\
18\end{array}$ & $\begin{array}{l}17 \\
30 \\
45 \\
59\end{array}$ & $\begin{array}{r}2 \\
8 \\
13 \\
18\end{array}$ & $\begin{array}{l}19 \\
38 \\
59 \\
78\end{array}$ \\
\hline Totaal & 19 & 35 & 36 & 10 & 45 \\
\hline
\end{tabular}

Bron: OECD/ROA

Tabel 5.5

Percentage niet-werkenden dat voldoende competent is, naar opleidingsniveau, 1994

\begin{tabular}{lc}
\hline Opleidingsniveau & $\begin{array}{c}\text { Voldoende } \\
\text { Competent } \\
\%\end{array}$ \\
\hline Basisonderwijs & 10 \\
V(M)BO (incl. MAVO) & 28 \\
HAVONWO en MBO & 50 \\
HBONO & 68 \\
Totaal & 36 \\
\hline
\end{tabular}

Bron: OECD/ROA

Evenals bij de werknemers is het voor niet-werkenden vooralsnog niet mogelijk om een beeld te krijgen van andere 'key-skills', die bepalend zijn voor de employability van niet-werkenden, zoals hun probleemoplossend vermogen en ICT-vaardigheden. 
Periode waarin geen betaald werk is verricht

De duur dat iemand geen betaald werk heeft verricht, bepaalt voor een belangrijk deel de mate waarin er sprake zal zijn van verouderde kwalificaties. Het langere tijd niet gebruiken van de kwalificaties waarover men beschikt, betekent immers dat deze kwalificaties steeds meer van hun waarde verliezen. Voor deze variabele is gebruik gemaakt van de cijfers uit de EBB.

In de laatste kolom van tabel 5.6 wordt het percentage niet-werkenden weergegeven dat langer dan één jaar geen betaald werk heeft verricht.

Tabel 5.6

Periode waarin niet-werkende geen betaald werk heeft verricht, naar opleidingsniveau, 1999

Categorie niet-werkenden
Opleidingsniveau

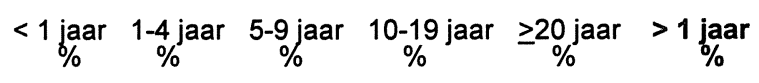

Niet-werkenden totaal

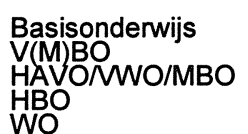

Totaal

Niet-werkende werkzoekenden

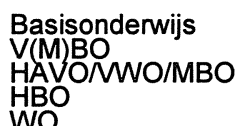

WO

Totaal

Niet-participerenden

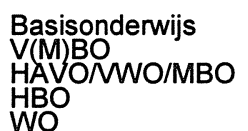

Totaal

Niet-participerenden met een arbeidshandicap

34

$\begin{array}{rrrrrr}26 & 34 & 19 & 14 & 3 & 71 \\ 38 & 40 & 13 & 7 & - & 60 \\ 47 & 34 & 12 & 5 & - & 52 \\ 42 & 33 & 12 & - & - & 35 \\ 48 & 35 & - & - & - & \\ & & & \mathbf{8} & 2 & 60\end{array}$

Basisonderwijs

$\mathrm{V}(\mathrm{M}) \mathrm{BO}$

HAVO/WWO/MBO

WBO

$\begin{array}{lll}18 & 37 & 2 \\ 31 & 44 & 1 \\ 37 & 41 & 1 \\ 43 & 33 & 13 \\ 52 & 30 & \end{array}$

39

26
16
15
13
-

$\begin{array}{rr}14 & - \\ 8 & - \\ 5 & - \\ - & -\end{array}$

77
68
61
46
30

Totaal

$\begin{array}{lll}28 & 33 & 17 \\ 41 & 38 & 12 \\ 52 & 31 & 10 \\ 42 & 32 & 12 \\ 44 & 40 & \end{array}$

17
12
10
12
13

14
6
5
-
-

69
57
46
43
40

57

$\begin{array}{rrrrrr}50 & 32 & - & - & - & 32 \\ 41 & 41 & - & - & - & 41 \\ 50 & 42 & - & - & - & 42 \\ - & - & - & - & - & - \\ - & - & 9 & - & - & 45\end{array}$


Tabel 5.6 (vervolg)

Periode waarin niet-werkende geen betaald werk heeft verricht, naar opleidingsniveau, 1999

Categorie niet-werkenden

Opleidingsniveau

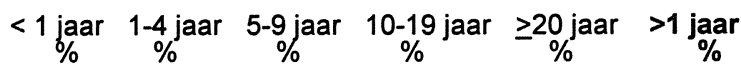

Niet-participerende vijftigplussers

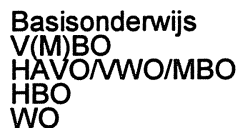

Totaal

Bron: CBS

Intredevermogen

Om het vermogen van niet-werkenden om in te treden in beeld te brengen moet worden bezien in hoeverre niet-werkenden direct beschikbaar zijn voor de arbeidsmarkt. Dit intredevermogen wordt in beeld gebracht door te kijken naar het percentage niet-werkenden dat binnen twee weken kan beginnen met werken. Vooralsnog kan op basis van het OSA-Aanbodpanel alleen voor niet-werkende werkzoekenden het intredevermogen in beeld worden gebracht. In tabel 5.7 wordt, verbijzonderd naar opleidingsniveau, het percentage niet-werkende werkzoekenden weergegeven dat binnen twee weken aan de slag zou kunnen.

Tabel 5.7

Percentage werkzoekenden dat binnen nu en twee weken kan beginnen, per opleidingsniveau, 1998

Categorie niet-werkenden

Opleidingsniveau

$\%$

Niet-werkende werkzoekenden

Basisonderwijs

VMBO

HAVONWO/MBO

HBO

WO

Totaal

90

\section{Bron: OSA}

Met gebruikmaking van de EBB data is eventueel een beter inzicht te verkrijgen in het intredevermogen van niet-werkenden. Een aanpassing in de routing van de EBB maakt een verdere verbijzondering naar groepen niet-werkenden mogelijk, zonder dat daarbij een te geringe celvulling voor problemen zal zorgen. 


\section{Mobiliteitsvermogen}

Het mobiliteitsvermogen is het vermogen dat een niet-werkende heeft om in verschillende functies in te treden. Hierbij is het vooral belangrijk om te kijken in hoeverre iemand te kampen heeft met 'ervaringsconcentratie', doordat men voorheen lange tijd werkzaam is geweest in één bepaalde functie. Het mobiliteitsvermogen kan het beste worden bepaald op basis van informatie over het aantal verschillende functies dat een niet-werkende in het verleden heeft bekleed, of op basis van informatie over de periode waarin men werkzaam was in de laatste functie die men uitoefende. Vooralsnog is er echter geen databron voorhanden, waarin deze informatie is te vinden. Daardoor is het in deze eerste opzet van de Employability Monitor niet mogelijk om het mobiliteitsvermogen van niet-werkenden in beeld te brengen.

\section{Opleidingsvermogen}

Het vermogen van niet-werkenden om zich te laten scholen is, evenals bij de werkenden, mede afhankelijk van hun opleidingsniveau. Dit opleidingsniveau is immers van grote invloed op iemands 'leervermogen'. De in tabel 5.1 gepresenteerde informatie over het opleidingsniveau van de niet-werkenden geeft dus ook een indicatie van hun opleidingsvermogen. Ook leeftijd kan voor het in beeld brengen van het opleidingsvermogen van belang zijn. Hoe ouder een werknemer is des te geringer is diens leervermogen (Salthouse, 1994). Dat oudere werknemers goed blijven functioneren danken zij meestal aan de opgebouwde ervaring. Nieuwe dingen leren gaat steeds moeizamer (Becker, 1964; Thijssen, 1992).

\section{Vermogen tot een brede kwantitatieve inzet}

Het vermogen van niet-werkenden om te werken onder onregelmatige arbeidstijdenregimes kan het beste worden geïndiceerd op basis van informatie over hun eerdere werkervaring. Heeft een niet-werkende bijvoorbeeld altijd op onregelmatige tijden gewerkt dan is het vermogen om dat bij intrede op de arbeidsmarkt weer te doen waarschijnlijk in voldoende mate aanwezig. Omdat dergelijke gegevens niet voorhanden zijn is vooralsnog het vermogen tot een brede kwantitatieve inzet niet in beeld gebracht. In de toekomst zou het OSA-Aanbodpanel mogelijk een interessante databron zijn, omdat daarin nu ook aandacht wordt geschonken aan het werken onder specifieke arbeidstijdenregimes, zij het alleen voor wat betreft inspanningen op dat gebied nu.

\section{Bereidheid}

Bij het bepalen van de employability-bereidheid van niet-werkenden wordt gekeken naar een viertal vormen van bereidheid: de intredebereidheid, mobiliteitsbereidheid, opleidingsbereidheid en de bereidheid tot een brede inzetbaarheid. De mobiliteitsbereidheid wordt, evenals bij de werknemers, onderverdeeld in de functionele mobiliteitsbereidheid en de geografische mobiliteitsbereidheid. Bij het in beeld brengen van de bereidheid tot een brede inzet wordt voor niet-werkenden alleen gekeken naar de bereidheid tot een brede kwantitatieve inzet. Primaire databron bij het in 
beeld brengen van de employability-bereidheid van niet-werkende werkzoekenden is het Hoe Zoeken Werkzoekenden bestand. Voor de overige categorieën is de EEB de meest bruikbare databron, aangevuld met gegevens afkomstig uit het OSA-Aanbodpanel.

Intredebereidheid

Bij het in beeld brengen van de intredebereidheid van niet-werkenden staat idealiter de vraag of niet-werkenden zouden willen werken centraal. Letterlijk wordt deze vraag in geen van de onderzochte databronnen gesteld, maar aan de hand van de vraag in het OSA-Aanbodpanel, of een niet-werkende werkzoekende in de afgelopen twaalf maanden iets heeft gedaan om aan werk te komen kan wel een indicatie worden verkregen van de bereidheid om aan de slag te komen. Bovendien kan aan de hand van de vraag of niet-participerenden denken binnen drie jaar weer op zoek te gaan naar een betaalde baan een beeld worden verkregen van de intredebereidheid van de niet-participerenden. Een verdere verbijzondering binnen de groep nietparticiperenden staat het OSA-Aanbodpanel niet toe.

Tabel 5.8

Intredebereidheid van niet-werkenden, naar opleidingsniveau, 1998

Categorie niet-werkenden

Opleidingsniveau

Niet-werkende werkzoekenden*

Basisonderwijs

VMBO

HAVO/MWO/MBO

HBO

WO

Totaal

Niet-participerenden ${ }^{* *}$

Basisonderwijs

VMBO

HAVO/WWO/MBO

HBO

WO

76

73

Totaal

Bron: OSA

* Het betreft hier degenen die de afgelopen 12 maanden actief naar werk hebben gezocht

** Het betreft hier degenen die denken binnen nu en 3 jaar weer op zoek te gaan naar een betaalde baan

Bovendien is het niet mogelijk de intredebereidheid van de gehele groep niet-werkenden in beeld te brengen. De routing in de vragenlijst van het OSA-Aanbodpanel maakt dit onmogelijk. 
Tabel 5.8 geeft een overzicht van het percentage niet-werkende werkzoekenden dat aangeeft in de afgelopen 12 maanden iets te hebben gedaan om aan werk te komen en het percentage niet-participerenden dat denkt binnen nu en drie jaar weer op zoek te gaan naar een betaalde baan. De percentages worden weergegeven per opleidingsniveau. Als databron is gebruik gemaakt van het OSA-Aanbodpanel.

\section{Functionele mobiliteitsbereidheid}

De functionele mobiliteitsbereidheid heeft betrekking op de bereidheid om in verschillende soorten functies te werken. Om de functionele mobiliteitsbereidheid van niet-werkenden in beeld te brengen zou hen dus idealiter gevraagd moeten worden naar hun beroepswens. Is deze beroepswens zeer specifiek dan is er sprake van een geringe mobiliteitsbereidheid. Geeft een niet-werkende te kennen in meerdere uiteenlopende functies geïnteresseerd te zijn, dan is sprake van een grote mobiliteitsbereidheid. Vooralsnog is het niet mogelijk de beroepswens van niet-participerenden in beeld te krijgen. Wel kan deze met behulp van het HZW voor nietwerkende werkzoekenden worden bepaald. In tabel 5.9 is per opleidingsniveau het percentage niet-werkende werkzoekenden weergegeven dat geen speciale voorkeur heeft voor een bepaalde functie.

Tabel 5.9

Percentage niet-werkenden dat geen speciale voorkeur heeft voor een bepaalde functie, naar opleidingsniveau, 1999

Categorie niet-werkenden

Opleidingsniveau

$\%$

Niet-werkende werkzoekenden

Basisonderwijs $\quad 42$

$\begin{array}{ll}\mathrm{V}(\mathrm{M}) \mathrm{BO} & 29\end{array}$

HAVO/NWO/MBO $\quad 19$

HBO 23

$\begin{array}{ll}\text { WO } & 15\end{array}$

$\begin{array}{ll}\text { Totaal } & 25\end{array}$

Bron: HZW

Geografische mobiliteitsbereidheid

De geografische mobiliteitsbereidheid van niet-werkenden kan in beeld worden gebracht door gebruik te maken van de in het HZW-bestand gestelde vraag naar het al dan niet bereid zijn om een baan te accepteren waarvoor men zou moeten verhuizen. In tabel 5.10 is, verbijzonderd naar opleidingsniveau, naast het percentage niet-werkenden dat bereid is een baan te accepteren waarvoor men zou moeten verhuizen ook een overzicht gegeven van de geografische mobiliteitsbereidheid van niet-werkende werkzoekenden en niet-participerenden. 
Tabel 5.10

Percentage niet-werkenden dat bereid is te verhuizen voor een baan, naar opleidingsniveau, 1999

Categorie niet-werkenden

Opleidingsniveau

Niet-werkenden totaal

Basisonderwijs

$\begin{array}{ll}\text { VMBO } & 17 \\ \text { VAVOMWOMBO } & 37\end{array}$

HAVO/WO/MBO $\quad 37$

$\begin{array}{ll}\mathrm{HBO} & 47\end{array}$

WO 45

$\begin{array}{ll}\text { Totaal } & 30\end{array}$

Niet-werkende werkzoekenden

Basisonderwijs 16

$\begin{array}{ll}\text { VMBO } & 17\end{array}$

HAVONWO/MBO

HBO

WO $\quad 46$

$\begin{array}{lr}\text { Totaal } & 29\end{array}$

Niet-participerenden

Basisonderwijs

VMBO

HAVO/WO/MBO

HBO

WO

Totaal

Bron: HZW

Opleidingsbereidheid

Aan de hand van de vraag of een niet-werkende bereid is een opleiding te volgen om daarmee zijn of haar kansen op werk te vergroten, kan de opleidingsbereidheid van niet-werkenden in kaart worden gebracht. Vooralsnog zijn er geen data beschikbaar over de opleidingsbereidheid van niet-werkenden. In de toekomst zou het OSAAanbodpanel mogelijk uitkomst kunnen bieden, aangezien vrij eenvoudig een vraag zou kunnen worden opgenomen over het al dan niet bereid zijn van personen om opleidingen te volgen die de kansen op werk vergroten.

Bereidheid tot brede kwantitatieve inzet

Om de bereidheid tot een brede kwantitatieve inzet in beeld te krijgen moet aan nietwerkenden worden gevraagd in hoeverre zij bereid zijn op onregelmatige tijden te werken, op zaterdag en zondag te werken, in wisseldiensten te werken, overuren te 
maken en zowel parttime als fulltime te werken. Deze informatie is deels beschikbaar via het HZW-bestand, waarin aan respondenten gevraagd wordt in hoeverre zij al dan niet een voorkeur hebben voor een bepaald dienstverband. Bovendien wordt hen gevraagd of zij de voorkeur geven aan een partime of fulltime betrekking en of zij een voorkeur hebben voor het aantal te werken uren per week. Tabel 5.11 geeft een overzicht van deze indicaties van de mate waarin werkzoekenden bereid zijn zich in kwantitatieve zin breed in te zetten. In de laatste kolom van de tabel wordt het percentage niet-werkenden vermeld dat geen voorkeur heeft voor een bepaald dienstverband of een bepaald aantal werkuren per week of de voorkeur geeft aan een werkweek van 35 uur of meer. Deze niet-werkenden zijn bereid zich qua werktijden en dienstverband flexibel op te stellen. In de toekomst zou aansluiting kunnen worden gezocht bij het OSA-Aanbodpanel, waarin nu reeds aandacht wordt besteed aan het werken onder verschillende arbeidstijdenregimes, maar waarin nog niet aan niet-werkenden wordt gevraagd of men bereid is om op onregelmatige tijden te werken of overuren te maken.

Tabel 5.11

Bereidheid om zich kwantitatief breed in te zetten, per categorie niet-werkenden, naar opleidingsniveau, 1999

\begin{tabular}{lccc}
\hline $\begin{array}{l}\text { Categorie niet-werkenden } \\
\text { Opleidingsniveau }\end{array}$ & $\begin{array}{l}\text { Geen voorkeur } \\
\text { vast of tijdelijk } \\
\text { dienstverband }\end{array}$ & $\begin{array}{l}\text { Geen voorkeur } \\
\text { voor dienstver- } \\
\text { band voor } \\
\text { minder dan } \\
35 \text { uur }\end{array}$ & $\begin{array}{l}\text { Breed } \\
\text { inzetbaar }\end{array}$ \\
& $\%$ & $\%$ & $\%$ \\
\hline
\end{tabular}

Niet-werkenden

Basisonderwijs
VMBO
HAVO/MO/MBO
HBO
WO

Totaal

Niet-werkende werkzoekenden

Basisonderwijs

VMBO

HAVONWO/MBO

HBO

WO

Totaal

Bron: HZW

\section{Inspanning}

Behalve het vermogen en de bereidheid van niet-werkenden om werk te krijgen moet ook een beeld worden gegeven van de inspanningen die niet-werkenden leveren om 
attractief te zijn voor werkgevers en aldus een plaats op de arbeidsmarkt te krijgen. Daarbij wordt een onderscheid gemaakt naar: intrede-inspanningen, functionele mobiliteitsinspanningen, opleidingsinspanningen en inspanningen op het gebied van de brede kwantitatieve inzetbaarheid. De databronnen die worden gebruikt om inzicht te krijgen in de mate waarin de diverse inspanningen worden geleverd, zijn het HZWbestand en de EBB.

Intrede-inspanningen

De intrede-inspanningen moeten worden opgevat als de inspanningen die een nietwerkende levert om aan de slag te komen. Om de intrede-inspanning in beeld te brengen is er voor gekozen om gebruik te maken van antwoorden op de vraag of niet-werkenden in de afgelopen vier weken iets hebben gedaan om aan werk te komen. Bij het bepalen van de intrede-inspanning wordt dus van een soortgelijke variabele gebruik gemaakt als bij het bepalen van de intredebereidheid. Hoewel hier in feite slechts sprake is van een gradueel verschil, zou men kunnen zeggen dat er van bereidheid al sprake is als iemand in de afgelopen 12 maanden iets heeft gedaan om aan werk te komen. Men levert intrede-inspanning als men zich in de afgelopen 4 weken heeft ingespannen om aan werk te komen.

In tabel 5.12 is het percentage niet-werkenden weergegeven dat in de afgelopen maand actief heeft gesolliciteerd, verbijzonderd naar opleidingsniveau. De databron die hierbij is gebruikt is het HZW bestand.

Tabel 5.12

Percentage niet-werkenden dat in de afgelopen 4 weken actief naar een baan heeft gezocht, naar opleidingsniveau, 1999

Categorie niet-werkenden

Opleidingsniveau

$\begin{array}{ll}\text { Niet-werkende werkzoekenden } & \\ \text { Basisonderwijs } & 30 \\ \text { VMBO } & 57 \\ \text { HAVOMWO/MBO } & 55 \\ \text { HBO } & 57 \\ \text { WO } & 56 \\ \text { Totaal } & 54\end{array}$

Bron: HZW

Functionele mobiliteitsinspanningen

Bij de functionele mobiliteitsinspanning van niet-werkenden wordt gekeken naar de verscheidenheid aan functies waarop een niet-werkende solliciteert. Spant een nietwerkende zich uitsluitend in om één bepaald soort functie te krijgen dan beperkt dit vanzelfsprekend de intredekans. Voor het in beeld brengen van de inspanningen op het gebied van de functionele mobiliteit ontbreekt momenteel een geschikte data- 
bron, waardoor het onmogelijk is de variabele in deze eerste opzet van de Employability Monitor in beeld te brengen.

\section{Opleidingsinspanningen}

Bij het in kaart brengen van de opleidingsinspanningen die niet-werkenden leveren om hun kansen op de arbeidsmarkt te vergroten, kan gebruik worden gemaakt van de beschikbare informatie in de EBB. In de EBB wordt aan niet-werkenden gevraagd of zij momenteel bezig zijn met een opleiding. De percentages zijn vermeld in tabel 5.13. Er is in de tabel verbijzonderd naar 5 opleidingsniveaus.

Tabel 5.13

Percentage niet-werkenden dat op dit moment een opleiding volgt, naar opleidingsniveau, 1998

Categorie niet-werkenden

Niet-werkenden

Basisonderwijs

$\mathrm{V}(\mathrm{M}) \mathrm{BO}$

5

HAVO/MO/MBO

HBO

WO

Totaal

Niet-werkende werkzoekenden

Basisonderwijs

$\mathrm{V}(\mathrm{M}) \mathrm{BO}$

HAVO/NWO/MBO

HBO

WO

Totaal

Niet-participerenden

Basisonderwijs

$\mathrm{V}(\mathrm{M}) \mathrm{BO}$

HAVO/NWO/MBO

HBO

WO

Totaal

Niet-participerende vijftigplussers

Basisonderwijs

$\mathrm{V}(\mathrm{M}) \mathrm{BO}$

HAVO/WVO/MBO

$\mathrm{HBO}$

WO 
Tabel 5.13 (vervolg)

Percentage niet-werkenden dat op dit moment een opleiding volgt, naar opleidingsniveau, 1998

Categorie niet-werkenden

Opleidingsniveau

Niet-participerenden met een arbeidshandicap

Basisonderwijs

$\mathrm{V}(\mathrm{M}) \mathrm{BO}$

HAVONWO/MBO

$\mathrm{HBO}$

WO

Totaal

Bron: CBS

Inspanningen op het gebied van een brede kwantitatieve inzetbaarheid

De inspanningen die niet-werkenden leveren om in kwantitatieve zin breed inzetbaar te zijn, kunnen in beeld worden gebracht door hen te vragen in hoeverre zij zich inspannen om een baan te krijgen ongeacht de werktijden. Een niet-werkende die alleen inspanningen levert om aan een parttime betrekking te komen met regelmatige werktijden, waarbij niet op zondag, niet op zaterdag en niet in wisselende diensten wordt gewerkt is op het punt van de kwantitatieve inzetbaarheid minder breed inzetbaar dan een niet-werkende die inspanningen levert in wat voor baan dan ook aan de slag te komen. Een databron die het mogelijk maakt het bovenstaande goed in beeld te brengen is echter niet beschikbaar.

Tabel 5.14

Inspanningen op het gebied van een brede kwantitatieve inzetbaarheid (aantal uren inzetbaar per week) van niet-werkende werkzoekenden, naar opleidingsniveau, 1999

\begin{tabular}{|c|c|c|c|}
\hline $\begin{array}{l}\text { Categorie niet-werkenden } \\
\text { Opleidingsniveau }\end{array}$ & $<20$ uur & $20-30$ uur & $\begin{array}{l}\geq 30 \\
\text { uur }\end{array}$ \\
\hline
\end{tabular}

Niet-werkende werkzoekenden

$\begin{array}{lrrr}\text { Basisonderwijs } & 29 & 7 & 59 \\ \text { V(M)BO } & 44 & 8 & 46 \\ \text { HAVONWO/MBO } & 43 & 9 & 45 \\ \text { HBO } & 38 & 12 & 47 \\ \text { WO } & 22 & 17 & 61 \\ \text { Totaal } & 39 & 9 & 49\end{array}$

Bron: CBS

De inspanningen van niet-werkenden om in kwantitatieve zin breed inzetbaar te zijn, kunnen voorlopig op een andere manier in beeld worden gebracht, namelijk door te kijken naar het aantal uren per week waarvoor een niet-werkende werk zoekt. Degenen die zoeken naar een functie voor 30 of meer uur per week kunnen als vol- 
doende breed inzetbaar worden beschouwd. Het is echter alleen mogelijk deze gegevens voor niet-werkende werkzoekenden op te nemen. Van de overige categorieën niet-werkenden is hierover geen informatie beschikbaar. De data die zijn gebruikt komen uit het $\mathrm{HZW}$ bestand en zijn weergegeven in tabel 5.14.

\section{Persoonlijke belemmeringen}

Om het beeld van de individuele employability van niet-werkenden compleet te maken is het ten slotte van belang dat wordt gekeken naar de mate waarin persoonlijke belemmeringen de arbeidsmarktintrede in de weg staan. De belemmeringen die daarbij de revue zullen passeren zijn achtereenvolgens de gezinssituatie en het al dan niet hebben van een arbeidshandicap. De gezinssituatie kan een belemmering vormen om tot arbeidsmarktintrede over te gaan, omdat de zorg voor thuiswonende kinderen het voor veel mensen onmogelijk maakt een fulltime functie te aanvaarden. Een arbeidshandicap maakt het voor niet-werkenden doorgaans extra moeilijk om aan de slag te komen, omdat (beperkt) arbeidsgehandicapten zonder additionele faciliteiten een functie, waarvoor zij in principe geschikt zijn, vaak niet optimaal kunnen invullen. De databronnen die zijn gebruikt bij het in beeld brengen van de persoonlijke belemmeringen zijn de EBB en het HZW-bestand.

\section{Gezinssituatie}

Een achttal mogelijke gezinssituaties kunnen de intredekans van niet-werkenden beïnvloeden. De acht mogelijke situaties zijn:

- alleenstaande zonder kind(eren) of anderen;

- alleenstaande ouder met kind(eren) of anderen van 0-5 jaar;

- alleenstaande ouder met kind(eren) of anderen van 6-11 jaar;

- alleenstaande ouder met kind(eren) of anderen van 12-17 jaar;

- gehuwd of samenwonend zonder kind(eren) of anderen;

- gehuwd of samenwonend met kind(eren) of anderen van 0-5 jaar;

- gehuwd of samenwonend met kind(eren) of anderen van 6-11 jaar;

- gehuwd of samenwonend met kind(eren) of anderen van 12-17 jaar.

De eerste categorie niet-werkenden ondervindt doorgaans de minste persoonlijke belemmeringen bij het intreden op de arbeidsmarkt. De tweede categorie de meeste. De overige categorieën vallen hier qua mate van belemmering tussenin.

In tabel 5.15 is, op basis van de beschikbare informatie in de EBB, per categorie nietwerkenden aangegeven welk percentage in de desbetreffende gezinssituatie verkeert, verbijzonderd naar opleidingsniveau. In de laatste kolom wordt het percentage niet-werkenden aangegeven dat waarschijnlijk belemmeringen ondervindt als gevolg van de gezinssituatie. Hierbij gaat het om de niet-werkenden met thuiswonende kinderen van zeventien jaar of jonger. 


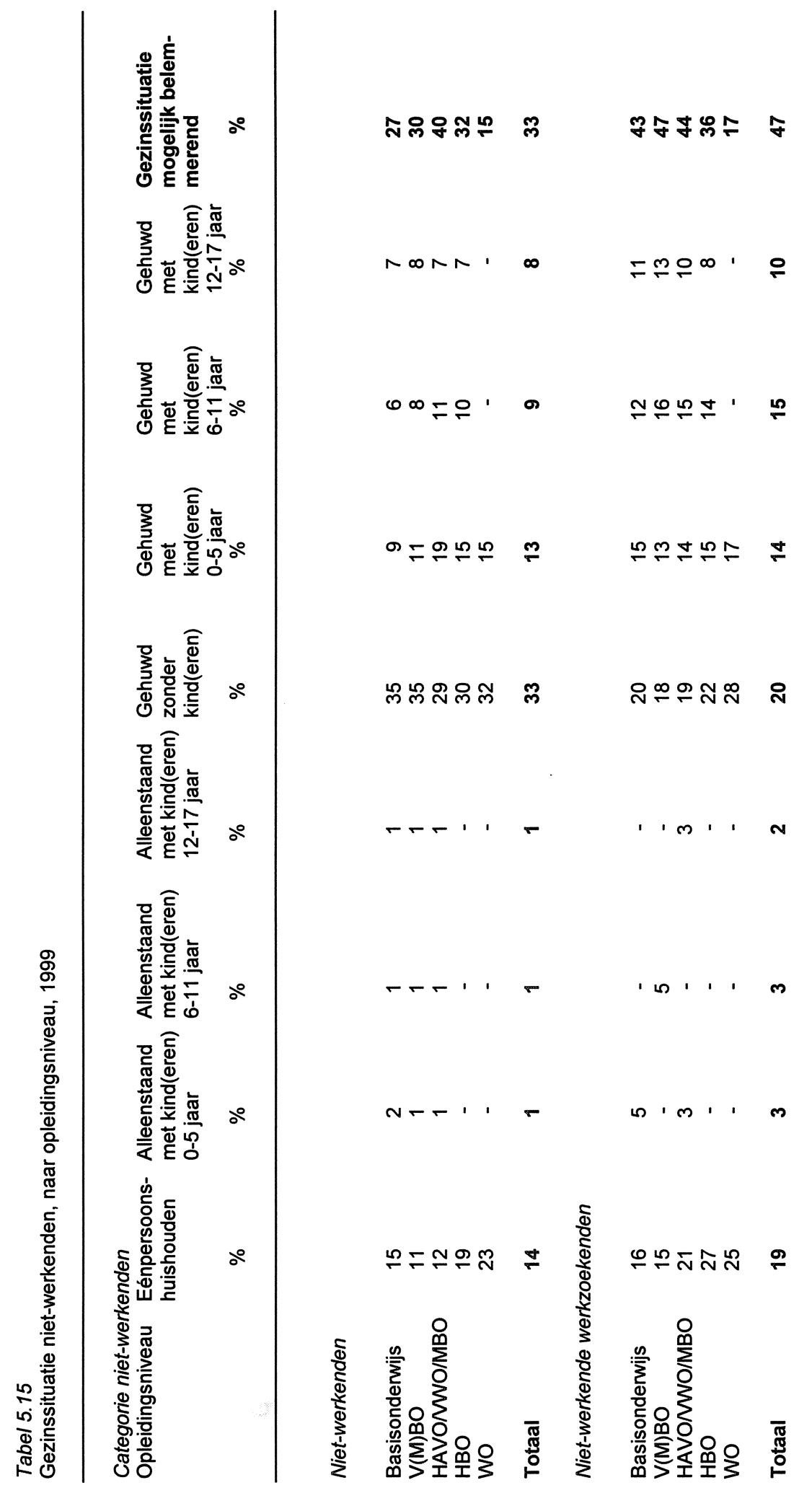




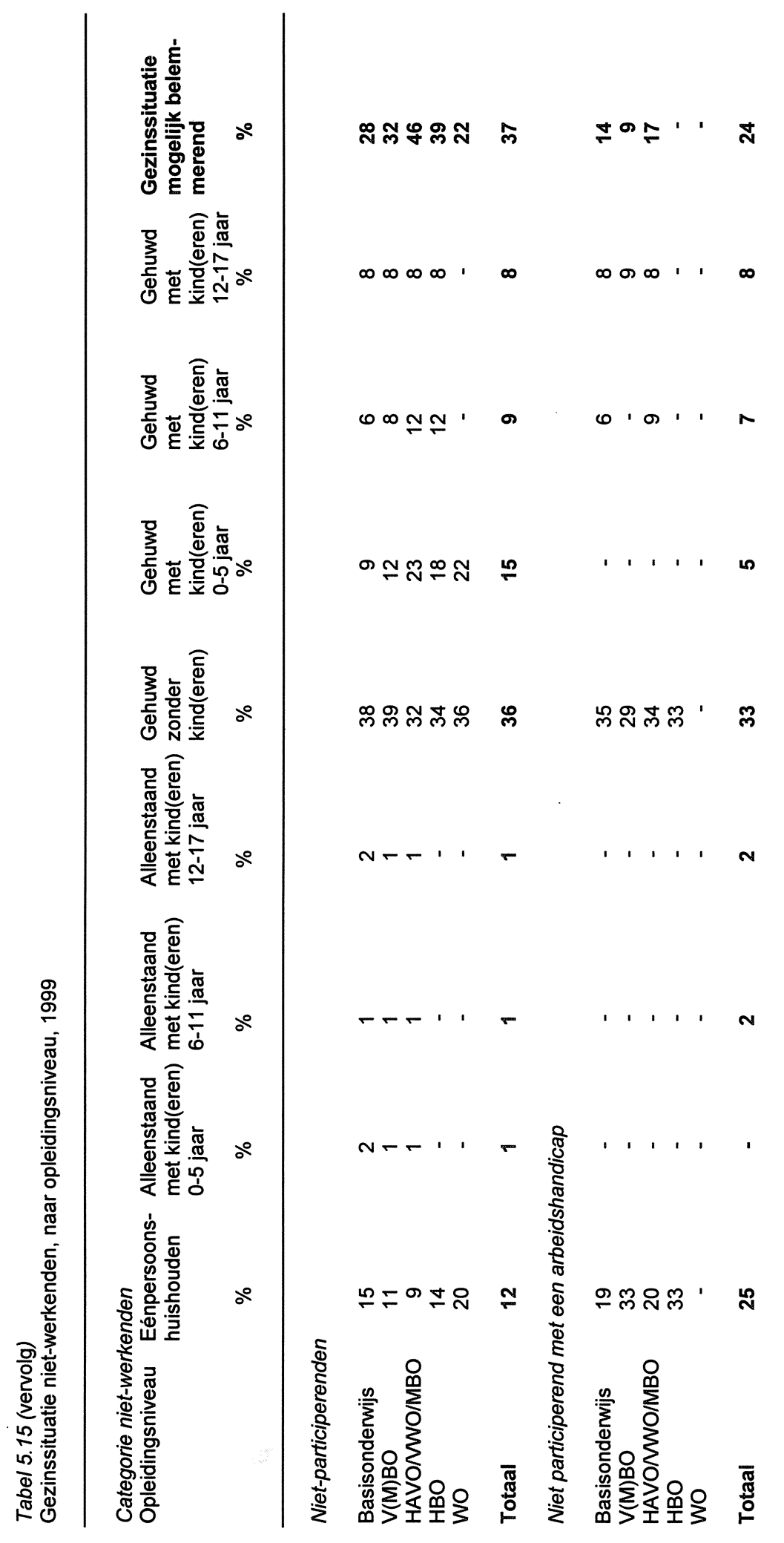




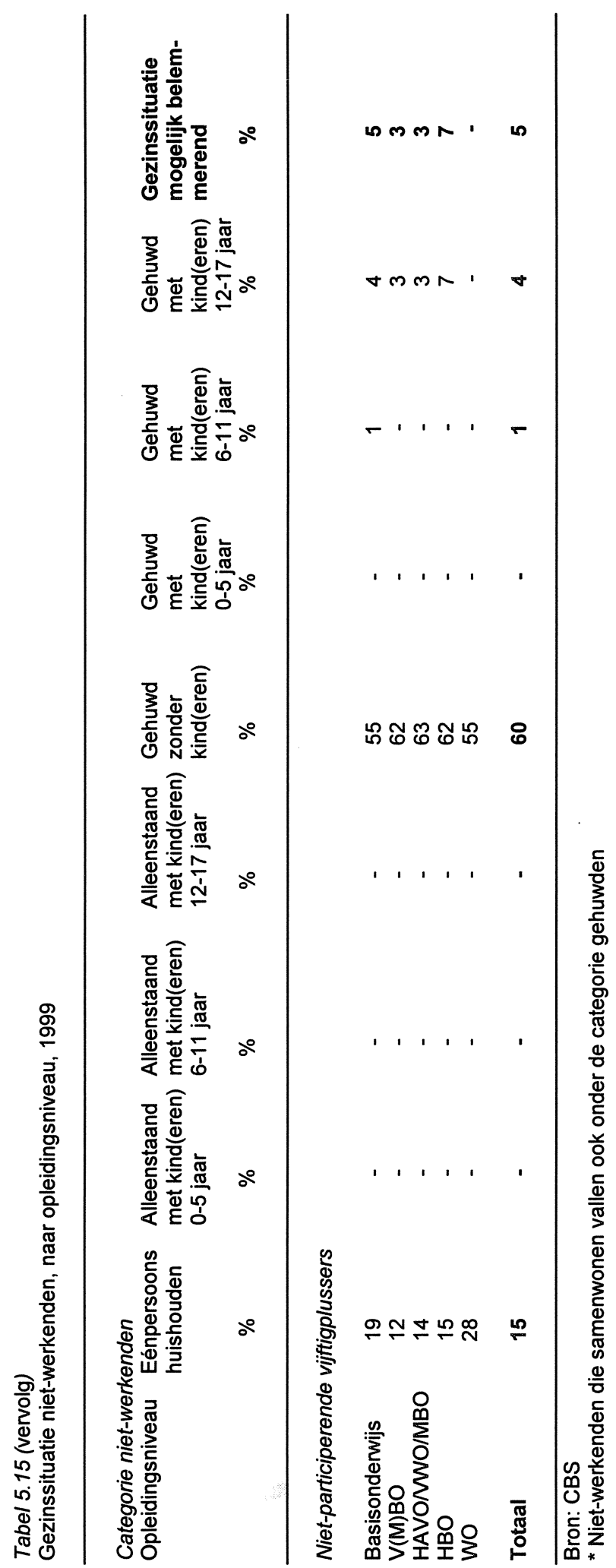




\section{Arbeidshandicap}

Om een goed beeld te krijgen van de mate waarin niet-werkenden als gevolg van een arbeidshandicap niet intreden, zou idealiter aan de niet-werkenden zelf gevraagd moeten worden of zij de idee hebben dat zij als gevolg van een bepaalde handicap moeilijkheden ervaren bij het vinden van een passende baan. Fot nu toe is een dergelijke vraag in geen van de onderzochte databronnen gesteld. In deze eerste opzet is derhalve voor een andere indicator gekozen en wel de aanwezigheid van een arbeidshandicap. Deze informatie is in principe beschikbaar in het HZW-bestand, waarin de vraag wordt gesteld of iemand geheel of gedeeltelijk arbeidsongeschikt is verklaard. Hierbij wordt de veronderstelling gemaakt dat een niet-werkende met een arbeidshandicap meer moeite heeft in te treden dan een niet-werkende die niet arbeidsgehandicapt is. In tabel 5.16 wordt het percentage niet-werkenden aangegeven dat te maken heeft met een arbeidshandicap.

Tabel 5.16

Percentage niet-werkenden dat mogelijk belemmerd wordt door een arbeidshandicap, 1999

Categorie niet-werkende

Niet-werkenden

Basisonderwijs

$\mathrm{V}(\mathrm{M}) \mathrm{BO}$

HAVOMWO/MBO

HBO 30

$\begin{array}{ll}\text { WO } & 15\end{array}$

$\begin{array}{ll}\text { Totaal } & 32\end{array}$

Niet-werkende werkzoekenden

Basisonderwijs $\quad 42$

$\mathrm{V}(\mathrm{M}) \mathrm{BO} \quad 36$

HAVONWO/MBO 29

HBO 23

WO 12

Totaal 31

Niet-participerenden

Basisonderwijs $\quad 30$

$\mathrm{V}(\mathrm{M}) \mathrm{BO}$

HAVONWO/MBO

HBO

WO 29

Totaal

Bron: HZW 


\subsection{Arbeidsmarktperspectieven van niet-werkenden}

In deze paragraaf wordt een beeld gegeven van de arbeidsmarktperspectieven van de verschillende groepen niet-werkenden. Hierbij is hun opleidingsachtergrond als uitgangspunt genomen. Dit bepaalt immers in belangrijke mate in welk soort functies zij op de arbeidsmarkt kunnen instromen. Voor het indiceren van de intredekans van niet-werkenden moet niet primair gekeken worden naar de arbeidsmarktsituatie op middellange termijn (5 jaar), maar veeleer naar de arbeidsmarktsituatie op de korte termijn (1 jaar). De arbeidsmarktsituatie wordt geschetst met gebruikmaking van de korte termijnprognoses die door het ROA recentelijk zijn opgesteld in het kader van het Project Onderwijs Arbeidsmarkt. Daarnaast wordt gekeken naar de uitwijkmogelijkheden die mensen met een bepaalde opleidingsachtergrond op de arbeidsmarkt hebben. Daarbij wordt gebruik gemaakt van gegevens uit de EBB. Bij het bezien van de arbeidsmarktperspectieven van niet-werkenden wordt geen onderscheid gemaakt naar de vier onderscheiden categorieën niet-werkenden.

\section{Werkgelegenheidskrimp of -groei}

In tabel 5.17 worden de verwachte uitbreidingsvraag en de (bruto) arbeidsmarktuitstroom naar opleidingssector weergegeven. Bovendien wordt de totale vraag naar arbeid per opleidingssector weergegeven. De uitbreidingsvraag is de vraag naar nieuwe arbeidskrachten die ontstaat door groei van de werkgelegenheid. Bij een negatieve uitbreidingsvraag is er dus sprake van een krimpende werkgelegenheid. De arbeidsmarktuitstroom bepaalt de (bruto) vervangingsbehoefte, dat wil zeggen: de vraag die ontstaat doordat de arbeidsplaatsen van werkenden die met pensioen gaan, arbeidsongeschikt worden of zich (tijdelijk) terugtrekken van de arbeidsmarkt opnieuw moeten worden opgevuld. Om de totale vraag naar arbeidskrachten te bepalen zijn de arbeidsmarktuitstroom en de uitbreidingsvraag bij elkaar opgeteld. In de tabel worden de korte termijnprognoses voor eind 2000 en eind 2001 gepresenteerd. De cijfers in de tabel zijn percentages.

Tabel 5.17

Verwachte uitbreidingsvraag, vervangingsvraag en totale vraag per opleidingssector in 2000 en 2001

\begin{tabular}{|c|c|c|c|c|c|c|}
\hline \multirow[t]{2}{*}{ Opleidingssector } & \multicolumn{2}{|c|}{$\begin{array}{l}\text { Uitbreidingsvraag } \\
2000 \quad 2001\end{array}$} & \multicolumn{2}{|c|}{$\begin{array}{c}\text { Vervangingsvraag } \\
2000 \quad 2001\end{array}$} & \multicolumn{2}{|c|}{$\begin{array}{l}\text { Totale vraag } \\
2000 \quad 2001\end{array}$} \\
\hline & $\%$ & $\%$ & $\%$ & $\%$ & $\%$ & $\%$ \\
\hline Basisonderwijs & $-2,9$ & $-3,5$ & 17,3 & 17,2 & 14,4 & 13,7 \\
\hline $\begin{array}{l}\text { VMBO theorie } \\
\text { VMBO landbouw en techniek } \\
\text { VMBO economie } \\
\text { VMBO verzorging }\end{array}$ & $\begin{array}{r}1,3 \\
-0,7 \\
-2,0 \\
0,3\end{array}$ & $\begin{array}{r}1,0 \\
-1,5 \\
-2,4 \\
0,2\end{array}$ & $\begin{array}{l}20,7 \\
13,6 \\
16,4 \\
20,1\end{array}$ & $\begin{array}{l}20,5 \\
13,4 \\
16,1 \\
19,9\end{array}$ & $\begin{array}{l}22,0 \\
12,9 \\
14,4 \\
20,4\end{array}$ & $\begin{array}{l}21,5 \\
11,9 \\
13,8 \\
20,1\end{array}$ \\
\hline HAVONWO & 4,4 & 3,9 & 18,9 & 18,8 & 23,3 & 22,7 \\
\hline
\end{tabular}


Tabel 5.17 (vervolg)

Verwachte uitbreidingsvraag, vervangingsvraag en totale vraag per opleidingssector in 2000 en 2001

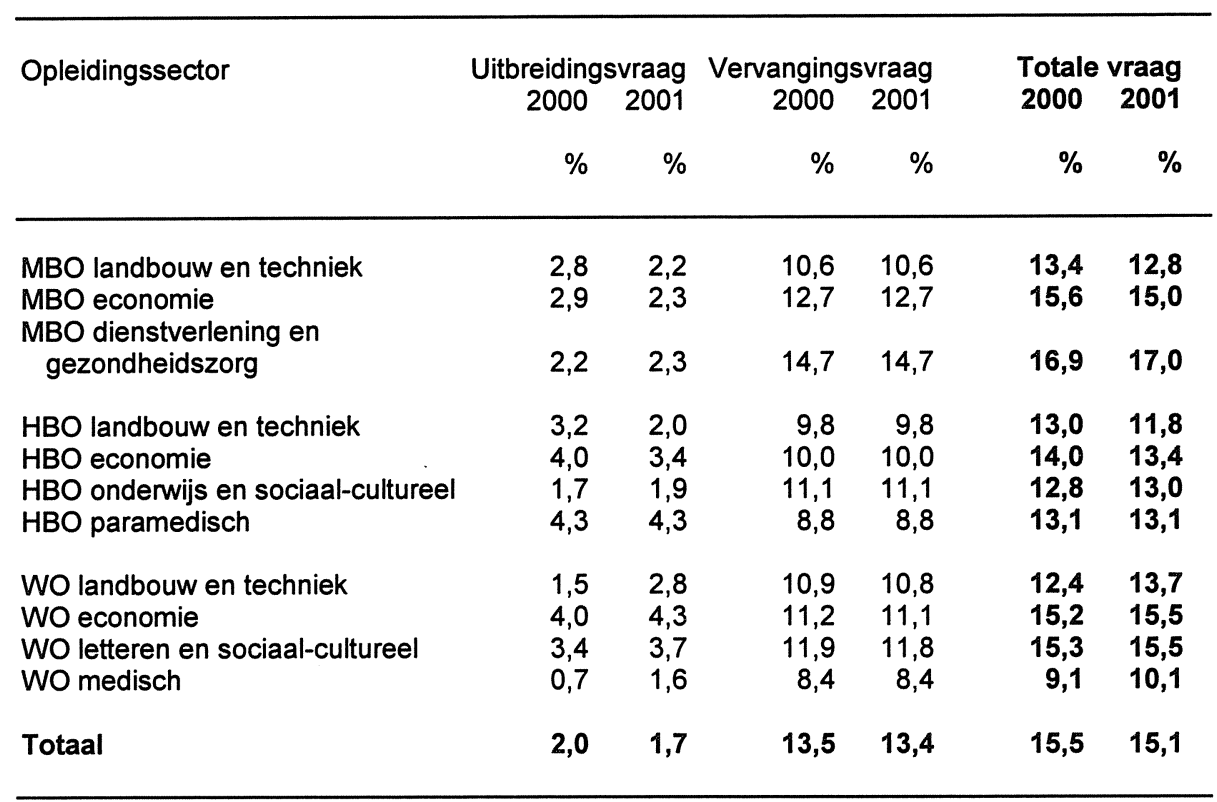

\section{Bron: ROA}

\section{Uitwijkmogelijkheden}

In tabel 5.18 wordt aangegeven in hoeverre niet-werkenden met een bepaalde opleidingsachtergrond naar bepaalde beroepen zouden kunnen uitwijken. Daarbij is gebruik gemaakt van de informatie die hierover beschikbaar is in het ROA-rapport De arbeidsmarkt naar opleiding en beroep tot 2004. De gepresenteerde spreidingsindex kan min of meer geïnterpreteerd worden als het aantal beroepsgroepen waarin men met een bepaalde opleidingsachtergrond zou kunnen gaan werken. Overigens moet worden beseft dat het in principe hebben van veel uitwijkmogelijkheden niet betekent dat er de komende jaren sprake is van een hoge vraag naar mensen met een bepaalde opleidingsachtergrond. Voor de verwachte ontwikkeling van de vraag naar mensen met een bepaalde opleidingsachtergrond wordt verwezen naar tabel 5.17.

Tabel 5.18

Uitwijkmogelijkheden naar verschillende beroepsgroepen per opleidingssector, gemiddelde 1997-1998 
Tabel 5.18 (vervolg)

Uitwijkmogelijkheden naar verschillende beroepsgroepen per opleidingssector, gemiddelde 1997-1998

\begin{tabular}{lr}
\hline Opleidingssector & Spreidingsindex \\
\hline HAVOMWO & 18,17 \\
& \\
MBO landbouw en techniek & 6,28 \\
MBO economie & 9,97 \\
MBO dienstverlening en gezondheidszorg & 6,09 \\
HBO landbouw en techniek & 9,44 \\
HBO economie & 10,54 \\
HBO onderwijs en sociaal-cultureel & 5,50 \\
HBO paramedisch & 2,53 \\
& 13,32 \\
WO landbouw en techniek & 8,06 \\
WO economie & 13,78 \\
WO letteren en sociaal-cultureel & 1,64 \\
WO medisch & \\
\hline Bron: ROA &
\end{tabular}

\section{Bron: ROA}

\section{Arbeidsmarktperspectieven}

In tabel 5.19 wordt per opleidingsniveau het percentage arbeidskrachten vermeld dat goede of zeer goede arbeidsmarktperspectieven heeft. Hierbij wordt gebruik gemaakt van de korte termijn arbeidsmarktprognoses van het ROA voor het jaar 2001 (zie Vlasblom et al. 2000)

\section{Tabel 5.19}

Percentage niet-werkenden met (zeer) goede arbeidsmarktperspectieven op de korte termijn, naar opleidingsniveau

\begin{tabular}{lc}
\hline Opleidingsniveau & $\%$ \\
\hline Basisonderwijs & \\
V(M)BO & 0 \\
HAVONWO/MBO & 4 \\
HBO & 50 \\
WO & 90 \\
Totaal & 95 \\
& 53 \\
\hline Bron: ROA & \\
\hline
\end{tabular}

\subsection{Effectueringscondities}

In deze paragraaf wordt een beeld gegeven van de effectueringscondities. Hierbij ligt de nadruk op de stimulansen van de overheid en het bedrijfsleven die de intredemogelijkheden voor niet-werkenden vergemakkelijken. De overheid vervult een be- 
langrijke rol bij het bieden van een wettelijk kader dat gericht is op het bevorderen van de (her)intrede van mensen uit specifieke doelgroepen, zoals arbeidsgehandicapten, langdurig niet-werkenden, personen met zorg voor (kleine) kinderen en ouderen. Hiertoe zijn diverse wettelijke maatregelen getroffen of in voorbereiding en zijn verschillende subsidies beschikbaar. Naast de overheid houden ook uitkeringsinstanties en organisaties als Arbeidsvoorziening zich bezig met de (re)integratie van nietwerkenden. In deze paragraaf zal in kaart worden gebracht welke subsidiemogelijkheden en reïntegratietrajecten voorhanden zijn om de activering van de groepen nietwerkenden te bespoedigen. Primaire databron hierbij is een aantal notities omtrent reïntegratie inspanningen en wetgeving op dat gebied.

\section{Institutioneel en fiscaal kader}

Tabel 5.20 gaat in op de institutionele fiscale maatregelen die zijn getroffen om intrede van groepen niet-werkenden te vergemakkelijken. Hierbij is met name gekeken naar de maatregelen die erop gericht zijn werkgevers te stimuleren werknemers, die moeite hebben aan de slag te komen als gevolg van bijvoorbeeld een arbeidshandicap, in dienst te nemen.

Tabel 5.20

Institutionele en fiscale maatregelen ter bevordering van de employability van niet-werkenden

Maatregel

Submaatregel

Inhoud (sub)maatregel

Doelgroep

WULBZ

Wet Uitbreiding Loon-door-Betalingsverplichting bij Ziekte. Verplicht de individuele werkgever om het loon van een zieke werknemer gedurende maximaal één jaar. Zet werkgevers er dus niet alleen toe aan verzuimbeleid te implementeren, maar ook voor reïntegratie te zorgen.

Wet PEMBA

Wet Premiedifferentiatie en marktwerking bij arbeidsongeschiktheidsverzekeringen. Werkgevers betalen verzekeringspremie afhankelijk van de uitstoot van werknemers naar de WAO. Hierdoor worden werkgevers gestimuleerd aandacht te besteden aan ARBO voorzieningen, zodat de uitstoot naar WAO beperkt blijft. Bovendien spannen werkgevers zich in om werknemers weer terug te laten keren na eventuele ziekte of gedeeltelijke arbeidshandicap. Reïntegratie wordt dus ook gestimuleerd.

\section{Wet REA}

De Wet op de Reïntegratie van Arbeidsgehandicapten is erop gericht de kansen op de arbeidsmarkt voor mensen met een arbeidshandicap te vergroten. De wet biedt herplaatsingsbudgetten voor werkgevers. Een werkgever kan dit budget aanwenden om een werkplek aan te passen, om mensen om-, her-, of bij- te scholen, om mensen in te werken of te begeleiden, om productieverlies te compenseren en/of om loonkosten te drukken.

\section{RSP}

De Regeling Schoonmaakdiensten Particulieren is een vorm van loonkostensubsidie. De doelstelling van de regeling is het verruimen van de markt voor huishoudelijke dienstverlening en de inschakeling van met name laag opgeleide langdurig werklozen.

Werkgevers/ werknemers

Werkgevers

Werkgevers

Laag opgeleide langdurig werklozen 
Tabel 5.20 (vervolg)

Institutionele en fiscale maatregelen ter bevordering van de employability van niet-werkenden

Maatrege

Submaatregel

Inhoud (sub)maatregel

Doelgroep

WIW

Wet Inschakeling Werkzoekenden. Gericht op het aan gemeenten bieden van een samenhangend instrumentarium. Om de afstand tot de arbeidsmarkt van langdurig werklozen, werkloze uitkeringsgerechtigden en werkloze jongeren te verkleinen dan wel te voorkomen dat deze afstand toeneemt. Het instrumentarium bestrijkt het gehele terrein van sociale activering, scholing, arbeidsbemiddeling, kinderopvang en mogelijkheden tot het toekennen van financiële incentives tot gesubsidieerde arbeid in de vorm van WIW-banen en WIW-ervaringsplaatsen. Overigens heeft de overheid zich voorgenomen om gemeenten vanaf 2001 in het kader van het Fonds Werk en Inkomen de mogelijkheid te bieden om niet benut geld voor WIW dienstbetrekkingen in te zetten voor scholing en activering. Gemeenten kunnen deze gelden gebruiken om fase-4 werklozen, arbeidsgehandicapten en mensen met een WIW dienstbetrekking naar de reguliere arbeidsmarkt toe te leiden.

ID-banen

In- en Doorstroombanen bieden extra werkgelegenheid via de gemeenten (in de collectieve en de non-profitsector), Gericht op de instroom in het arbeidsproces en op doorstroom.

WVA

Werkgevers kunnen op grond van de Wet Vermindering Afdracht loonbelasting en premie volksverzekeringen voor verschillende groepen werknemers de loonkosten aanzienlijk verlagen. Op grond van deze wet hoeven werkgevers minder loonbelasting en premies voor de volksverzekeringen af te dragen dan ze hebben ingehouden. De WVA kent acht afdrachtverminderingen, waarvan er drie specifiek op (re)integratie van langdurig werklozen zijn gericht, te weten:

- Afdrachtvermindering lage lonen (SPAK):

Voor iedere werknemer die tot $115 \%$ van het wettelijk minimumloon verdient kan bijna 4.000 gulden in mindering worden gebracht op de af te dragen premies en belasting. Toepassen van deze regeling verlaagt de loonkosten voor laagbetaalden met maximaal $10 \%$.

- Doorstroom-afdrachtvermindering lage lonen (doorstroom SPAK): Geldt voor werknemers van 23 jaar en ouder die niet meer verdienen dan $130 \%$ van het wettelijk minimumloon. De doorstroomvermindering bedraagt maximaal 2.040 gulden.

- Afdrachtvermindering langdurig werklozen (VLW):

Korting van 4.750 gulden per jaar op de afdracht van loonbelasting en premies volksverzekering voor elke langdurig werkloze die wordt aangenomen. Wordt de VLW gecombineerd met de SPAK dan kunnen de loonkosten voor laagbetaalden met maximaal $23 \%$ worden verlaagd.

Langdurig

werklozen

Langdurig

werklozen

Werkgevers

Werkgevers

Werkgevers

langdurig

werklozen

De SPAK heeft inmiddels voor ruim 45.000 werknemers werkgelegenheid opgeleverd. De VLW heeft ruim 10.000 langdurig werklozen aan een baan geholpen. Overigens is het mogelijk de afdrachtvermindering lage lonen (SPAK) te combineren met de afdrachtvermindering langdurig werklozen (VLW) en de afdrachtvermindering onderwijs (VO) (zie tabel 4.29). Hierbij kan het voordeel per werknemer oplopen tot maximaal 11.490 gulden per jaar. 
Tabel 5.20 (vervolg)

Institutionele en fiscale maatregelen ter bevordering van de employability van niet-werkenden

\section{Maatregel}

Submaatregel

Inhoud (sub)maatregel

Doelgroep

\section{WSW}

Wet Sociale Werkvoorziening. Gericht op het bieden van aangepast werk in een beschermde omgeving aan Arbeidsgehandicapten. De regeling kent ook een doorstroomfunctie.

Arbeidsgehandicapten

\section{Faciliteiten}

Behalve het institutioneel en fiscaal kader is het ook van belang dat helder in beeld komt welke vormen van hulp en begeleiding er worden geboden aan groepen nietwerkenden die niet of nauwelijks op eigen kracht aan de slag kunnen komen. Met name de door uitvoeringsinstanties (UVI's) en Arbeidsvoorziening aangeboden (re)integratietrajecten zijn hierbij van belang.

Tabel 5.21

Overzicht van de verschillende faciliteiten die voor bepaalde groepen niet-werkenden beschikbaar zijn

\begin{tabular}{|c|c|c|}
\hline Maatregel & Doelgroep & Uitvoerende instantie \\
\hline $\begin{array}{l}\text { Basisdienstverlening } \\
\text { Activering en controle }\end{array}$ & $\begin{array}{l}1 \text { (fase } 1,2,3,4 \text { ) } \\
1 \text { (fase } 1,2,3,4)\end{array}$ & $\begin{array}{l}\text { Arbeidsvoorziening } \\
\text { UVI's }\end{array}$ \\
\hline $\begin{array}{l}\text { Reïntegratietrajecten } \\
\text { Prestatie-bijdrage } \\
\text { ESF3 } \\
\text { Reïntegratiebudget } \\
\text { Sluitende aanpak } \\
\text { WIW: scholing en activering }\end{array}$ & $\begin{array}{l}1 \text { (fase } 2,3 \text { ) } \\
1 \text { (fase } 2,3,4 \text { ) } \\
1 \text { (fase } 2,3 \text { ) } \\
1 \text { (fase } 2,3,4 \text { ) } \\
1 \text { (fase } 2,3,4 \text { ) }\end{array}$ & $\begin{array}{l}\text { Arbeidsvoorziening } \\
\text { Arbeidsvoorziening } \\
\text { UVl's } \\
\text { Arbeidsvoorziening } \\
\text { Gemeenten }\end{array}$ \\
\hline $\begin{array}{l}\text { Gesubsidieerde arbeid } \\
\text { ID-banen (In en Doorstroom) } \\
\text { WIW: werkervaringsplaatsen en } \\
\text { dienstbetrekkingen }\end{array}$ & $\begin{array}{l}1 \text { (fase } 2,3,4 \text { ) } \\
1 \text { (fase } 3,4)\end{array}$ & $\begin{array}{l}\text { Gemeenten } \\
\text { Gemeenten }\end{array}$ \\
\hline
\end{tabular}

In tabel 5.21 wordt gekeken naar faciliteiten, die erop gericht zijn de intredekansen van groepen niet-werkenden te vergroten. De faciliteiten die in de tabel vermeld zijn worden door arbeidsvoorziening en uitkerende instanties aangeboden. In de tabel is enkel een opsomming gegeven van de beschikbare regelingen. 


\section{Communicatie}

Naast wetgeving en bestaande faciliteiten die de arbeidsmarktintrede van nietwerkenden kunnen bevorderen, is het ook van belang een beeld te krijgen van de bekendheid van niet-werkenden met de bestaande faciliteiten en wetgeving. Zijn nietwerkenden immers niet of nauwelijks op de hoogte van het feit dat er subsidies beschikbaar zijn om hun intrede op de arbeidsmarkt te bevorderen dan lijkt de afstand tot de arbeidsmarkt voor hen mogelijk groter dan deze in werkelijkheid is. Zij kunnen daardoor ontmoedigd worden en zich niet beschikbaar stellen voor betaalde arbeid. Vooralsnog is inzicht in de bekendheid van niet-werkenden met bestaande faciliteiten, maatregelen en wetten nauwelijks gemeten. Voor de toekomst is het van belang dat op basis van de inventarisatie van institutionele en fiscale maatregelen en faciliteiten ook wordt geïnventariseerd in hoeverre niet-werkenden van dergelijke voorzieningen op de hoogte zijn.

Ook over de bekendheid van werkgevers met bepaalde regelingen en wetten zou informatie verzameld moeten worden, aangezien de mate waarin werkgevers bekend zijn met regelingen die gericht zijn op het vergemakkelijken van de arbeidsmarktintrede van groepen niet-werkenden medebepalend is voor de intredekansen van deze groepen niet-werkenden. Is het bestaan van bijvoorbeeld een reïntegratieregeling bij werkgevers onbekend dan is de kans dat een werkgever er gebruik van maakt gering en de effectiviteit van een dergelijke regeling dus beperkt. Vooralsnog is hieromtrent geen informatie beschikbaar hieromtrent, waardoor het onmogelijk is deze factoren mee te nemen bij de inrichting van deze eerste opzet van de Employability monitor voor niet-werkenden. 


\section{Employability Index}

In dit zesde hoofdstuk wordt invulling gegeven aan de tweede doelstelling van deze haalbaarheidsstudie: het ontwikkelen van een 'samenvattende' Employability Index. Op basis van de belangrijkste resultaten uit beide voorgaande hoofdstukken wordt voor zowel werknemers als niet-werkenden een Employability Index gecreëerd. Met deze indices is het mogelijk een vergelijking te maken tussen de verschillende groepen mensen. In paragraaf 6.1 wordt de Sectorale Employability Index voor werknemers gepresenteerd. Deze index maakt het mogelijk om in één oogopslag verschillende bedrijfssectoren met elkaar te vergelijken op een aantal centrale aspecten van de employability van werknemers. In paragraaf 6.2 wordt de Employability Index voor niet-werkenden gepresenteerd. Op basis van de beschikbare data is het niet mogelijk gebleken afzonderlijke indexcijfers te construeren voor de vier in hoofdstuk 2 onderscheiden categorieën niet-werkenden (niet-werkende werkzoekenden, niet-participerenden met een werkende partner, niet-participerende vijftigplussers en niet-participerenden met een arbeidshandicap). Wel is een verbijzondering gemaakt naar opleidingsniveau.

\subsection{Sectorale Employability Index voor werknemers}

In deze paragraaf wordt aan de hand van de gegevens in hoofdstuk 4 de Sectorale Employability Index gepresenteerd. Deze index wordt, op basis van het in het conceptuele model aangereikte raamwerk, geconstrueerd in vijf stappen:

Stap 1: De individuele employability per bedrijfssector;

Stap 2: De behoefte aan employability binnen bedrijfssectoren;

Stap 3: De arbeidsmarktperspectieven van werknemers binnen bedrijfssectoren op middellange termijn;

Stap 4: De effectueringscondities zoals die per bedrijfssector zijn geschapen;

Stap 5: Constructie van de samenvattende Sectorale Employability Index.

Voor alle in dit hoofdstuk geconstrueerde indices geldt dat, indien de cijfers van een bepaalde variabele niet betrouwbaar zijn, als gevolg van een te gering aantal waarnemingen, deze scores ook in de index niet zijn meegenomen. Voor een aantal van de 35 onderscheiden bedrijfsklassen is het dus niet mogelijk op een betrouwbare wijze de relatieve positie op de verschillende indices en de totaalindex te bepalen.

\section{Stap 1: de individuele employability}

Allereerst wordt in stap 1 per bedrijfssector de individuele employability van de werknemers in kaart gebracht. Hierbij wordt gekeken naar de vier centrale aspecten: Vermogen, Bereidheid, Inspanning en Persoonlijke belemmering. De scores van individuele werknemers op deze vier aspecten worden bepaald met behulp van een of meerdere variabelen. Zo wordt het employability-vermogen van werknemers bepaald door te kijken naar het opleidingsniveau, de werkervaring en het mobiliteitsvermogen. Met behulp van indexcijfers, waarbij de totaalscore van de gehele populatie voor 
de verschillende variabelen telkens op 100 is gesteld, kan een totaalindex worden gecreëerd. Daarbij worden de afzonderlijke indexcijfers opgeteld en gedeeld door het aantal variabelen dat is gebruikt. Van verdere weging wordt vooralsnog afgezien omdat het gewicht van de verschillende aspecten per sector, organisatie en soms zelfs functie verschilt. De weging wordt dus voorlopig overgelaten aan de gebruiker van deze Employability Monitor. Alvorens echter de totaalindex op te stellen, is gekeken naar de onderlinge correlatie van de verschillende variabelen die een bepaald aspect van de individuele employability meten. Wanneer bijvoorbeeld drie variabelen worden gebruikt om een aspect in beeld te brengen en twee van deze variabelen correleren onderling sterk met elkaar, dan is de kans groot dat deze beide variabelen in feite hetzelfde meten. Wanneer beide variabelen niettemin even zwaar mee zouden tellen zouden zij een te zwaar gewicht krijgen in de index van het desbetreffende employability-aspect. Om dit te voorkomen is ervoor gekozen in geval van een sterke onderlinge correlatie slechts één van de correlerende variabelen mee te nemen bij het vaststellen van de indexscore ${ }^{13}$ op een van de vier aspecten.

Bij de constructie van de uiteindelijke individuele Employability Index wordt aan de gebruikte variabelen een gelijk gewicht toegekend. Dit betekent dat bij de constructie van de individuele employability index, vermogen een gewicht van drie krijgt, bereidheid eveneens een gewicht van drie, inspanning een gewicht van zes en persoonlijke belemmeringen een gewicht van één. Op die manier telt elke variabele uiteindelijk dus even zwaar mee. Vooralsnog worden de scores op de volgende variabelen meegenomen bij het bepalen van de individuele employability van werknemers per bedrijfssector $^{14}$ :

- Vermogen:

- opleidingsniveau (tabel 4.1);

- werkervaring (tabel 4.6);

- mobiliteitsvermogen (tabel 4.7).

- Bereidheid:

- functionele mobiliteitsbereidheid (tabel 4.8);

- opleidingsbereidheid (tabel 4.9);

- bereidheid tot een brede kwalitatieve inzet (tabel 4.10).

- Inspanning:

- functionele mobiliteitsinspanningen (tabel 4.11);

- geografische mobiliteitsinspanningen (tabel 4.12);

- opleidingsinspanningen (tabel 4.13);

- kwalitatieve inzetbaarheidsinspanning (tabel 4.14);

- kwantitatieve inzetbaarheidsinspanning: flexibiliteit qua werktijden (tabel 4.15);

- kwantitatieve inzetbaarheidsinspanning: betaalde en onbetaalde overuren (tabel 4.16).

13. Voor deze aanpak is gekozen omdat andere methoden (bijv. factoranalyse) niet effectiever zijn gebleken en bovendien in de praktijk vaak minder inzichtelijk.

14. Er kan vanzelfsprekend alleen gebruik gemaakt worden van variabelen waarvoor data beschikbaar zijn. 
- Persoonlijke belemmeringen:

- gezinssituatie (tabel 4.17).

In tabel 6.1 wordt een zo compleet mogelijk beeld geschetst van de individuele employability van werknemers verbijzonderd naar bedrijfssector. Analyse van de onderlinge correlaties tussen de voor de index relevante variabelen maakt duidelijk dat, zoals verwacht mocht worden, met name de correlatie tussen opleidingsniveau en competentieniveau relatief hoog is (.637). Derhalve is ervoor gekozen de variabele die het competentieniveau weergeeft niet te betrekken in de berekening van de index van het employability-vermogen.

Tabel 6.1

Individuele Employability Index, naar bedrijfssector

\begin{tabular}{|c|c|c|c|c|c|}
\hline Bedrijfssector & $\begin{array}{c}\text { Vermogen } \\
\text { Index }\end{array}$ & $\begin{array}{l}\text { Bereidheid } \\
\text { Index }\end{array}$ & $\begin{array}{c}\text { Inspanning } \\
\text { Index }\end{array}$ & $\begin{array}{l}\text { Persoonlijke } \\
\text { Belemmeringen } \\
\text { Index }\end{array}$ & $\begin{array}{l}\text { Individuele } \\
\text { Employability } \\
\text { Index }\end{array}$ \\
\hline $\begin{array}{l}\text { Landbouw en visserij } \\
\text { Tuinbouw } \\
\text { Veehouderij } \\
\text { Akkerbouw, bosbouw } \\
\text { en visserij }\end{array}$ & $\begin{array}{r}99 \\
101 \\
-\end{array}$ & $\begin{array}{r}112 \\
112 \\
-\end{array}$ & $\begin{array}{r}76 \\
- \\
75 \\
-\end{array}$ & $\begin{array}{l}90 \\
96 \\
88 \\
86\end{array}$ & $\begin{array}{r}91 \\
91 \\
-\end{array}$ \\
\hline $\begin{array}{l}\text { Voeding } \\
\text { Vlees- en visbewerking } \\
\text { Overige } \\
\text { voedingsproducten } \\
\text { Drank en } \\
\text { tabaksproducten }\end{array}$ & $\begin{array}{r}94 \\
81 \\
95 \\
105\end{array}$ & $\begin{array}{r}99 \\
89 \\
106 \\
90\end{array}$ & $\begin{array}{r}114 \\
106 \\
121 \\
105\end{array}$ & $\begin{array}{r}98 \\
97 \\
94 \\
160\end{array}$ & $\begin{array}{r}105 \\
95 \\
109 \\
106\end{array}$ \\
\hline $\begin{array}{l}\text { Chemie } \\
\text { Basischemie } \\
\text { Eindproducten chemie } \\
\text { Kunststofverwerking }\end{array}$ & $\begin{array}{r}108 \\
113 \\
109 \\
-\end{array}$ & $\begin{array}{r}100 \\
84 \\
118 \\
-\end{array}$ & $\begin{array}{r}110 \\
126 \\
99 \\
-\end{array}$ & $\begin{array}{l}93 \\
81 \\
93 \\
97\end{array}$ & $\begin{array}{r}106 \\
110 \\
105 \\
-\end{array}$ \\
\hline $\begin{array}{l}\text { Metaal en } \\
\text { elektrotechniek } \\
\text { Basismetaal } \\
\text { Metaalproducten } \\
\text { Machine-industrie } \\
\text { Elektrotechniek } \\
\text { Transportmiddelen }\end{array}$ & $\begin{array}{r}95 \\
105 \\
87 \\
97 \\
96 \\
91\end{array}$ & $\begin{array}{r}102 \\
110 \\
81 \\
118 \\
93 \\
116\end{array}$ & $\begin{array}{r}100 \\
121 \\
104 \\
97 \\
77 \\
111\end{array}$ & $\begin{array}{r}101 \\
70 \\
102 \\
101 \\
108 \\
100\end{array}$ & $\begin{array}{r}99 \\
111 \\
94 \\
102 \\
87 \\
107\end{array}$ \\
\hline $\begin{array}{l}\text { Overige industrie } \\
\text { Textiel }\end{array}$ & $\begin{array}{l}94 \\
83\end{array}$ & $\begin{array}{l}101 \\
109\end{array}$ & $\begin{array}{r}92 \\
112\end{array}$ & $\begin{array}{l}116 \\
124\end{array}$ & $\begin{array}{r}96 \\
105\end{array}$ \\
\hline $\begin{array}{l}\text { Hout- en } \\
\text { bouwmaterialen } \\
\text { Papier } \\
\text { Grafische industrie }\end{array}$ & $\begin{array}{r}87 \\
93 \\
106\end{array}$ & $\begin{array}{r}93 \\
132 \\
95\end{array}$ & $\begin{array}{r}79 \\
95 \\
101\end{array}$ & $\begin{array}{l}121 \\
115 \\
113\end{array}$ & $\begin{array}{r}87 \\
105 \\
102\end{array}$ \\
\hline Energie & 102 & 68 & 110 & 104 & 98 \\
\hline
\end{tabular}


Tabel 6.1 (vervolg)

Individuele Employability Index, naar bedrijfssector

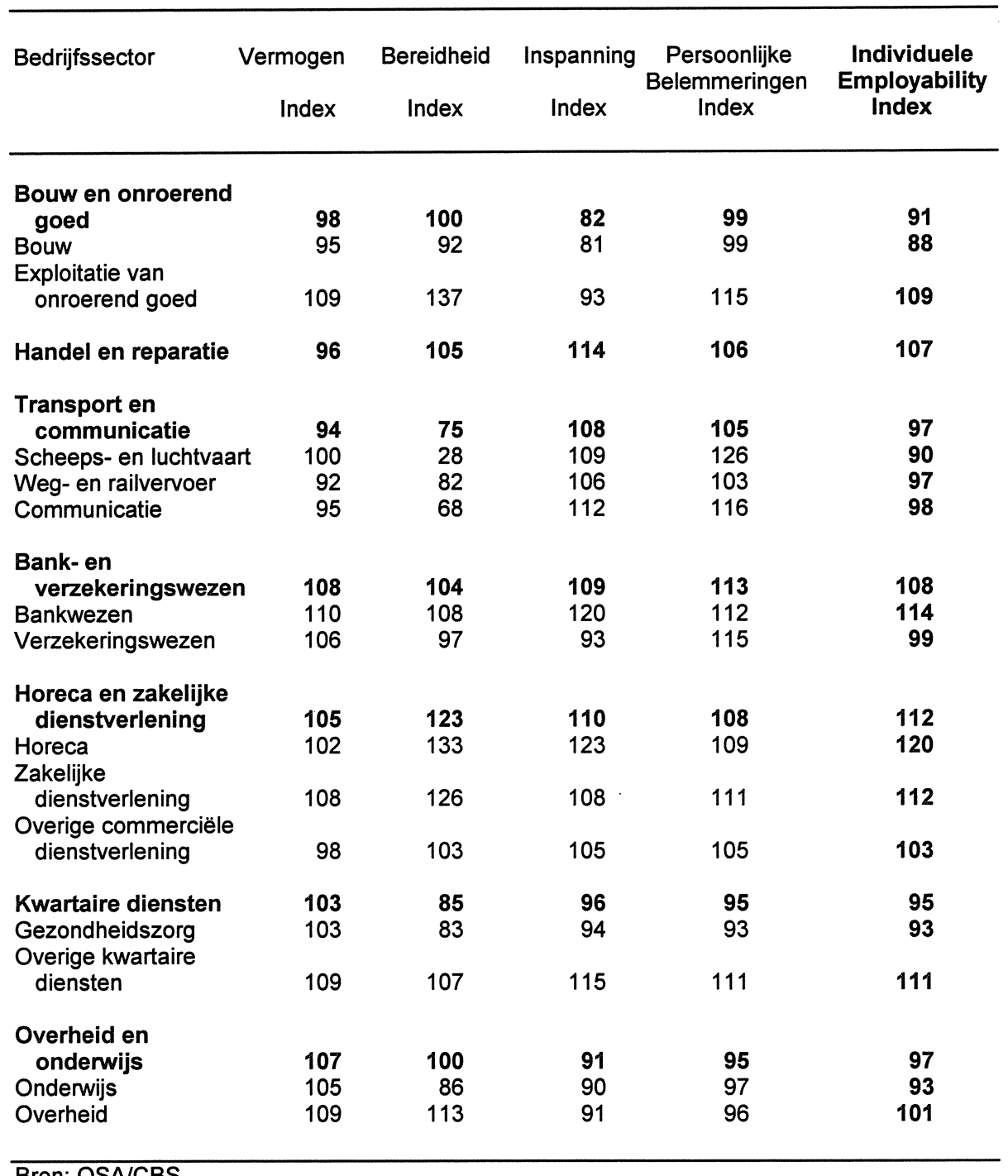

Bron: OSA/CBS

Stap 2: behoefte aan employability

In stap 2 wordt de sectorale behoefte aan employability bepaald. Hierbij wordt gekeken naar een zestal ontwikkelingen die de behoefte versterken, te weten:

- demografische ontwikkelingen (tabel 4.18);

- $\quad$ economische ontwikkelingen (tabel 4.19;

- $\quad$ technologische ontwikkelingen (tabel 4.20);

- $\quad$ organisatorische ontwikkelingen (tabel 4.21);

- $\quad$ fysiek belastende arbeidsomstandigheden (tabel 4.22); 
psychisch belastende arbeidsomstandigheden (tabel 4.23).

Om een totaaloverzicht van de sectorale employability-behoefte te kunnen geven is evenals bij de individuele employability een index geconstrueerd voor elk van de behoefte-indicatoren. Vervolgens zijn de afzonderlijke indices samengenomen en is een totaalindex gecreëerd. Hierbij is vanzelfsprekend ook weer gekeken naar onderlinge correlaties.

In tabel 6.2 wordt de sectorale behoefte aan employability in kaart gebracht. Hierbij is gekeken naar een zestal variabelen, die bepalend zijn voor de employability-behoefte. Zoals in hoofdstuk 2 werd aangegeven, spelen met name economische, technologische en organisatorische ontwikkelingen hierbij een belangrijke rol, maar ook demografische ontwikkelingen en de mate waarin sprake is van fysiek en psychisch belastende arbeidsomstandigheden zijn bepalend voor de behoefte van bedrijven aan employable personeel. Omdat elke ontwikkeling op zichzelf staat, is bij het bepalen van de sectorale behoefte aan employability geen nadere weging toegepast. Voor enkele bedrijfssectoren is het vanwege een te geringe celvulling niet mogelijk bepaalde indexcijfers op een betrouwbare manier te bepalen. Daardoor kan het totaalindexcijfer voor deze sectoren niet op basis van alle onderliggende variabelen worden bepaald.

\section{Stap 3: Arbeidsmarktperspectieven}

In stap 3 worden de arbeidsmarktperspectieven van werkenden binnen verschillende bedrijfssectoren geschetst. Hierbij is wederom gebruik gemaakt van indexcijfers gebaseerd op het percentage werknemers per bedrijfssector dat goede tot zeer goede arbeidsmarktperspectieven heeft. De hier gebruikte gegevens komen uit tabel 4.26.

In tabel 6.3 wordt per bedrijfssector aangegeven in hoeverre de werkenden in de desbetreffende sector een opleidingsachtergrond hebben waarvan de arbeidsmarktsituatie gunstig is. Naarmate een bedrijfssector hoger scoort op deze index, betekent dit dat er voor een hoger percentage werknemers in deze sector gunstige arbeidsmarktperspectieven bestaan. De arbeidsmarkt is gunstig als er sprake is van goede tot zeer goede arbeidsmarktperspectieven. 


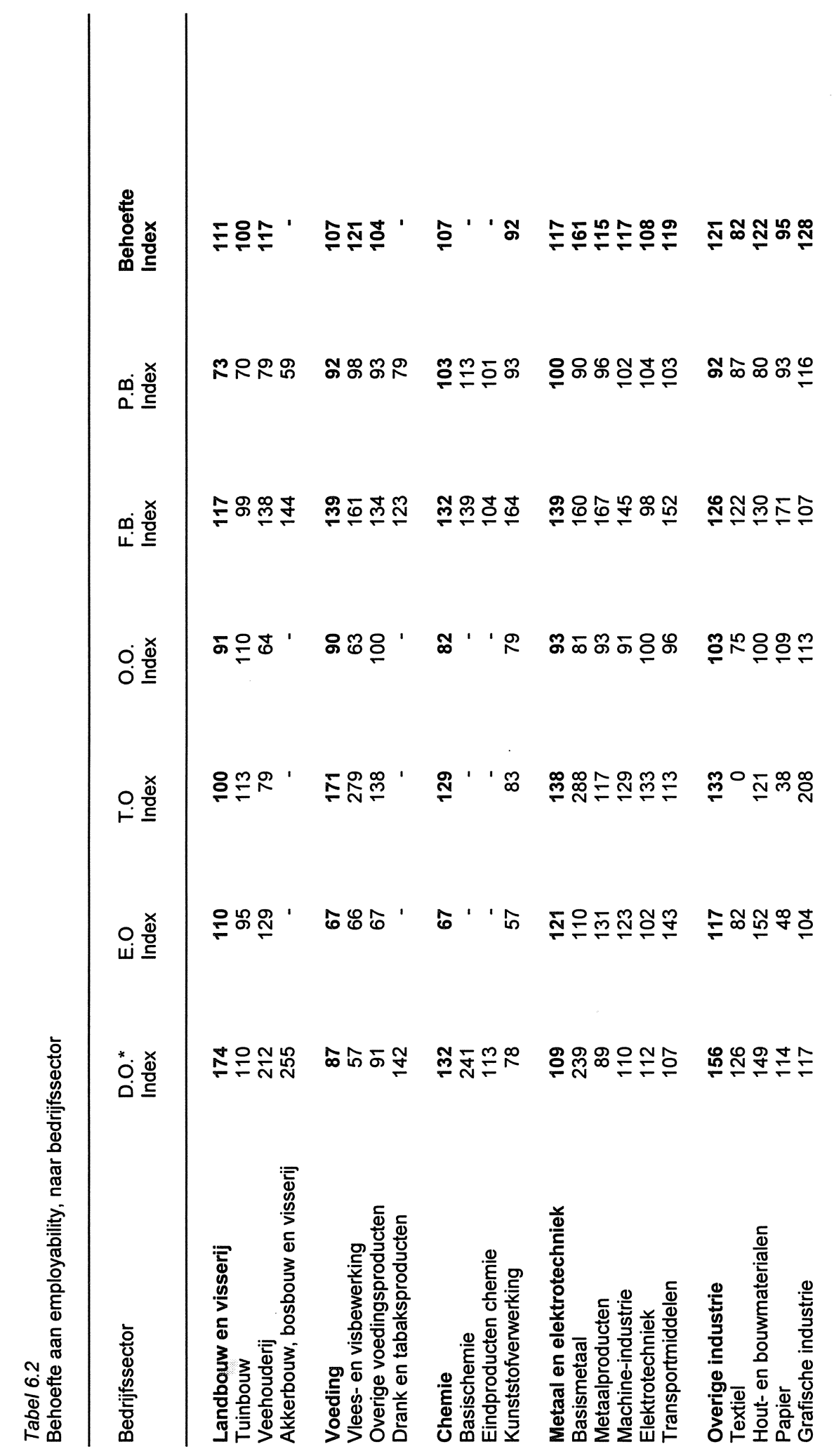




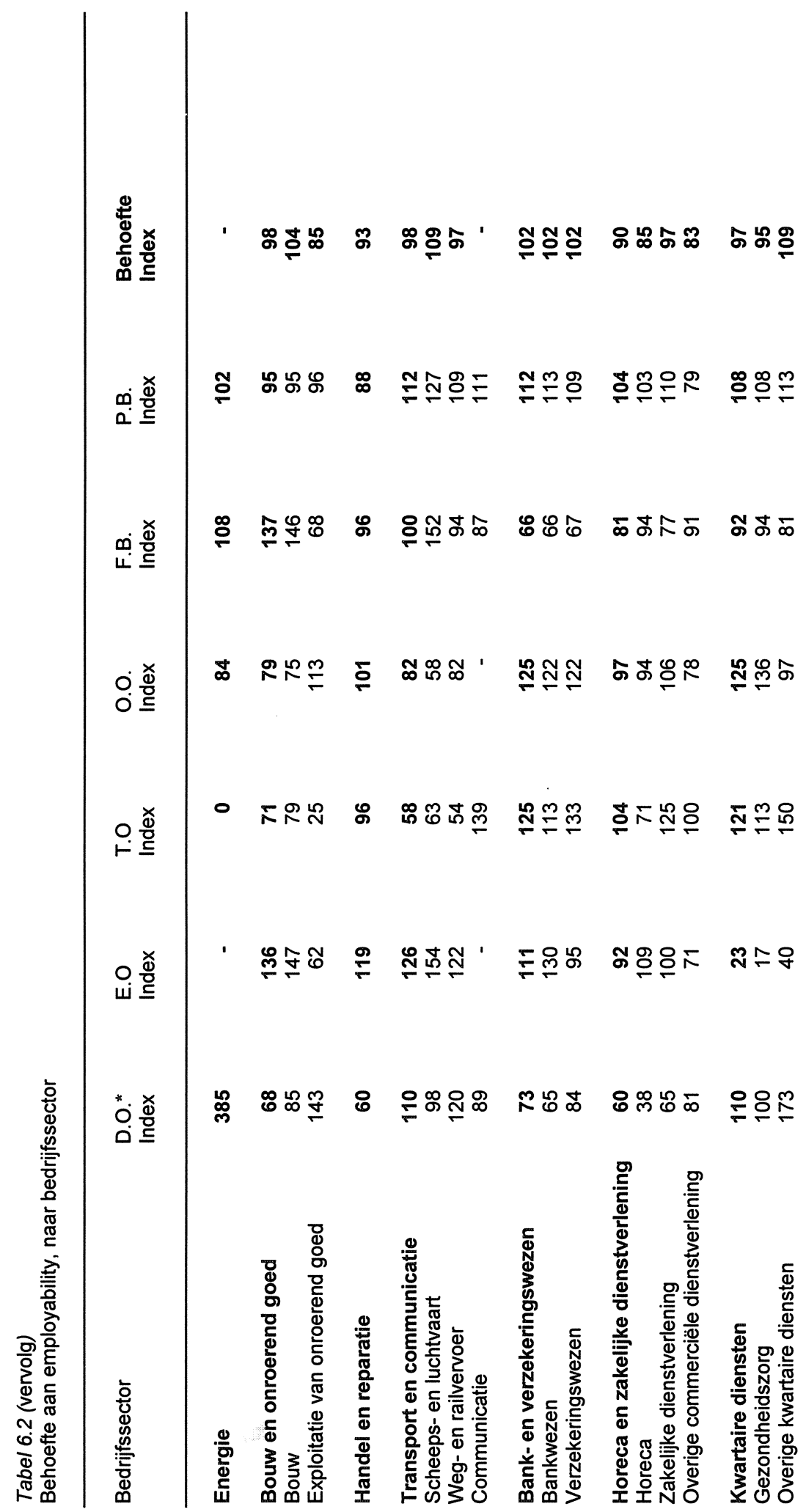




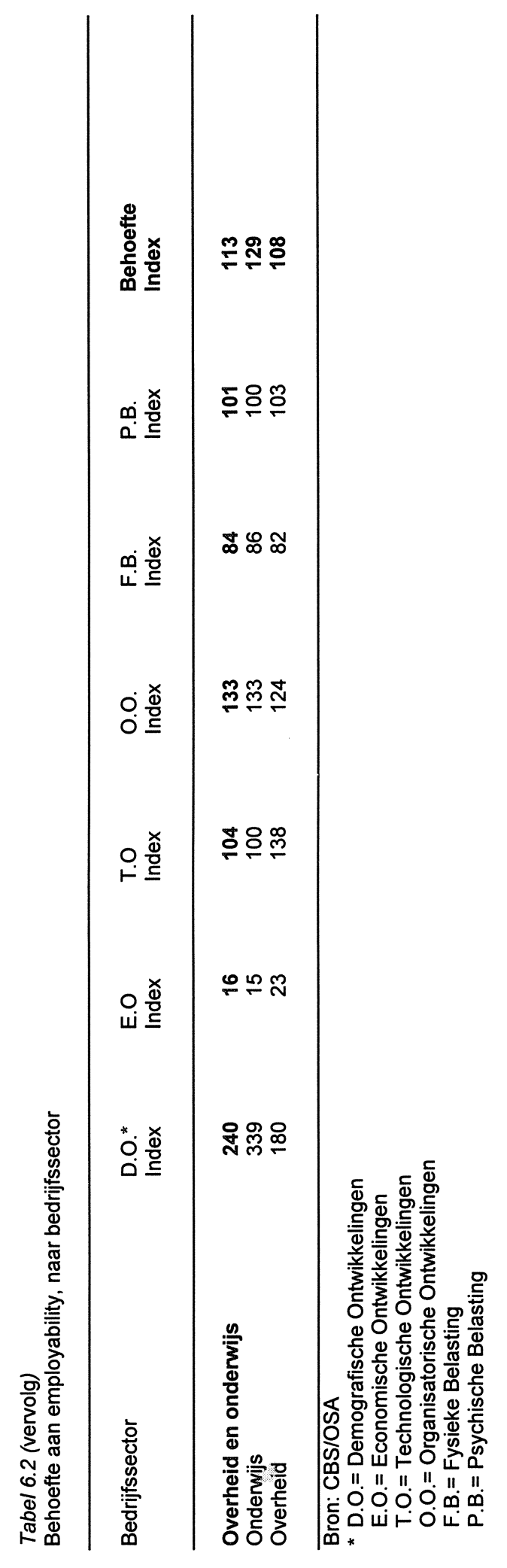


Tabel 6.3

Arbeidsmarktperspectieven van werknemers, per bedrijfssector

Bedrijfssector

(Zeer) goede arbeidsmarktperspectieven index

Landbouw en visserij

85

Tuinbouw

Veehouderij

61

Akkerbouw, bosbouw en visserij

Voeding

53

Vlees- en visbewerking 33

Overige voedingsproducten $\quad 58$

Drank en tabaksproducten $\quad 60$

Chemie $\quad 80$

Basischemie 106

Eindproducten chemie $\quad 86$

Kunststofverwerking 39

Metaal en elektrotechniek

Basismetaal 48

Metaalproducten 36

Machine-industrie $\quad 57$

Elektrotechniek $\quad 81$

$\begin{array}{ll}\text { Transportmiddelen } & 40\end{array}$

Overige industrie $\quad 54$

Textiel $\quad 54$

Hout- en bouwmaterialen $\quad 44$

Papier $\quad 47$

$\begin{array}{ll}\text { Grafische industrie } & 76\end{array}$

$\begin{array}{ll}\text { Energie } & 78\end{array}$

Bouw en onroerend goed 39

Bouw $\quad 32$

Exploitatie van onroerend goed 100

$\begin{array}{ll}\text { Handel en reparatie } & 87\end{array}$

Transport en communicatie $\quad 93$

Scheeps- en luchtvaart $\quad 131$

Weg-en railvervoer $\quad 94$

Communicatie $\quad 74$

Bank- en verzekeringswezen 111

Bankwezen 118

$\begin{array}{ll}\text { Verzekeringswezen } & 101\end{array}$

Horeca en zakelijke dienstverlening 117

$\begin{array}{lr}\text { Horeca } & 81\end{array}$

Zakelijke dienstverlening $\quad 127$

Overige commerciële dienstverlening 116

Kwartaire diensten $\quad 130$

$\begin{array}{ll}\text { Gezondheidszorg } & 127\end{array}$

Overige kwartaire diensten 146 
Tabel 6.3 (vervolg)

Arbeidsmarktperspectieven van werknemers, per bedrijfssector

Bedrijfssector

(Zeer) goede arbeidsmarktperspectieven

index

Overheid en onderwijs

Onderwijs

Overheid

196

Bron: ROA

\section{Stap 4: effectueringscondities}

In stap 4 wordt vervolgens aan de hand van een groot aantal verschillende variabelen per bedrijfssector bepaald in hoeverre de werknemers in een bepaalde bedrijfssector in staat worden gesteld hun employability op peil te houden c.q. te versterken (de 'effectueringscondities'). Hierbij wordt in eerste instantie bekeken in hoeverre in CAO's aandacht bestaat voor de employability-problematiek. Bovendien wordt gekeken naar de mate waarin binnen bedrijfssectoren faciliteiten worden geboden om de employability van werknemers op peil te houden. Om het beeld van de effectueringscondities zo volledig mogelijk te krijgen, is gekeken naar de volgende variabelen:

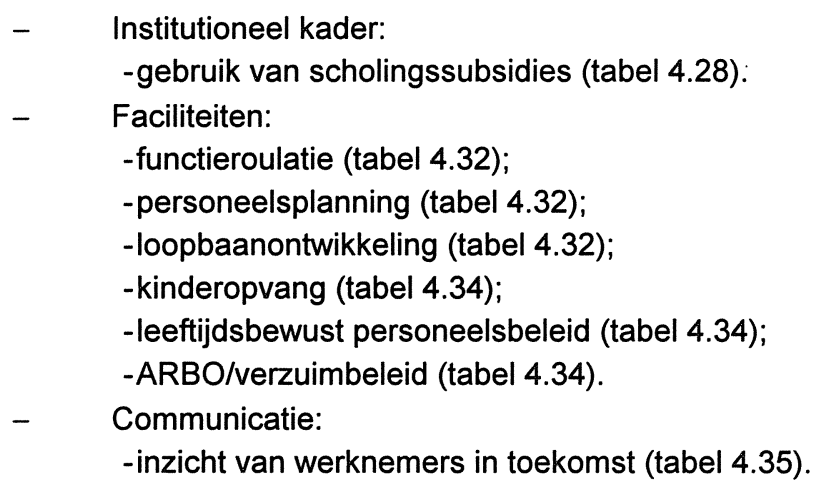

Op basis van bovenstaande variabelen wordt een totaalindex gecreëerd op dezelfde wijze als dat in de stappen 1 en 2 gebeurde. Hierbij doet zich echter het probleem voor dat bij het in beeld brengen van de effectueringscondities niet in alle gevallen dezelfde sectorindeling is gebruikt. De variabelen die meten in hoeverre afspraken zijn gemaakt in CAO's zijn slechts verbijzonderd naar 10 bedrijfssectoren, terwijl de variabelen die een beeld geven van de door bedrijven geboden faciliteiten deels naar 35 bedrijfssectoren en deels naar 13 bedrijfssectoren worden verbijzonderd. Het gebruik van verschillende databronnen maakt deze verschillende indelingen onvermijdelijk. Er is bij de constructie van de index om deze reden alleen gebruik gemaakt van gegevens die beschikbaar zijn voor zowel 13 bedrijfssectoren als 35 bedrijfsklassen. De overige cijfers blijven vooralsnog buiten beschouwing. 
In tabel 6.4 wordt met behulp van een index weergegeven in hoeverre er binnen de verschillende bedrijfssectoren gunstige effectueringscondities bestaan. Hierbij wordt gekeken naar de faciliteiten die worden geboden en de mate waarin werknemers inzicht hebben in hun eigen toekomst. Omdat de cijfers die betrekking hebben op het institutionele kader, waarbinnen bedrijven hun beleid kunnen inrichten, alleen kunnen worden bepaald voor een afwijkende indeling van 13 bedrijfssectoren, kon bij het bepalen van de index voor de effectueringscondities geen gebruik worden gemaakt van de meeste van deze variabelen. Wel wordt het gebruik van subsidiemogelijkheden in de index meegenomen.

Tabel 6.4

Effectueringscondities, per bedrijfssector

Bedrijfssector

Effectueringscondities

Index

Landbouw en visserij

73

Tuinbouw

Veehouderij

Akkerbouw, bosbouw en visserij

Voeding

Vlees- en visbewerking

119

Overige voedingsproducten

Drank en tabaksproducten

Basischemie

Eindproducten chemie

Kunststofverwerking

Metaal en elektrotechniek

Basismetaal

Metaalproducten

Machine-industrie

Elektrotechniek

Transportmiddelen

Overige industrie

Textiel

Hout- en bouwmaterialen

Papier

Energie $\quad 123$

Bouw en onroerend goed $\quad 105$

Bouw 102

$\begin{array}{ll}\text { Exploitatie van onroerend goed } & 127\end{array}$

Handel en reparatie $\quad 82$

$\begin{array}{ll}\text { Transport en communicatie } & 79\end{array}$

Scheeps- en luchtvaart $\quad 64$

$\begin{array}{ll}\text { Weg- en railvervoer } & 79\end{array}$

Communicatie 


\begin{tabular}{lc}
\hline Bedrijfssector & $\begin{array}{c}\text { Effectueringscondities } \\
\text { Index }\end{array}$ \\
\hline Bank- en verzekeringswezen & 131 \\
Bankwezen & 166 \\
Verzekeringswezen & 97 \\
Horeca en zakelijke dienstverlening & 85 \\
Horeca & 84 \\
Zakelijke dienstverlening & 90 \\
Overige commerciële dienstverlening & 97 \\
Kwartaire diensten & 144 \\
Gezondheidszorg & 167 \\
Overige kwartaire diensten & 82 \\
Overheid en onderwijs & 141 \\
Onderwijs & 136 \\
Overheid & 178 \\
& \\
\hline
\end{tabular}

Bron: OSA

Stap 5: Constructie van de samenvattende Sectorale Employability Index

In stap 5 worden de vier geconstrueerde dimensie-indices met elkaar geconfronteerd, zodat een compleet beeld ontstaat van de relatieve positie die bedrijfssectoren ten opzichte van elkaar innemen, voor wat betreft de stand van zaken op het gebied van de employability van werknemers en de arbeidsmarktsituatie in de verschillende bedrijfssectoren. Elk van de vier dimensies heeft echter voor de totale employabilitysituatie van een bedrijfssector een even grote betekenis, zodat ervoor gezorgd moet worden dat elk van de vier dimensies bij de constructie van de Sectorale Employability Index een even groot gewicht krijgt. Bij het uitvoeren van de verschillende opeenvolgende confrontaties zal er dus telkens voor gewaakt worden dat de te confronteren variabelen, aspecten en dimensies even zwaar mee wegen. Het is vervolgens aan de gebruiker van deze monitor om op basis van de eigen prioriteiten te bepalen in hoeverre op bepaalde aspecten acties nodig zijn. De Sectorale Employability Index biedt enkel een totaaloverzicht, maar heeft niet de intentie waarde-oordelen te geven.

In de eerste fase van de constructie van de SEI worden de behoefte aan en het aanbod van employability tegen elkaar afgezet. Dit gebeurt door het individuele employability indexcijfer te delen door het behoefte indexcijfer. Uit deze confrontatie volgt een ratio die aangeeft in hoeverre er, gerelateerd aan de sectorale employability-behoefte, in een bepaalde bedrijfssector in vergelijking met andere sectoren mogelijk tekorten bestaan aan werknemers met een goede employability. De resultaten van deze confrontatie zijn weergegeven in tabel 6.5. In de tabel zijn de ratio's vermenigvuldigd met 100 , zodat direct te zien is in hoeverre een bedrijfssector een relatief 'employability-tekort' dan wel een 'employability-overschot' heeft. Een 
score van meer dan 100 betekent dat een sector ten opzichte van andere sectoren beter voorziet in de bestaande employability-behoefte. Scoort een sector minder dan 100 dan betekent dit dat de employability van de werkenden mogelijk tekort schiet.

Tabel 6.5

Relatieve tekorten aan employability per bedrijfssector

$\begin{array}{cc}\text { Bedrijfssector } & \begin{array}{c}\text { Relatieve tekorten } \\ \text { Index }\end{array}\end{array}$

Landbouw en visserij

Tuinbouw

Veehouderi]

Akkerbouw, bosbouw en visserij

Voeding

Vlees- en visbewerking

Overige voedingsproducten

Drank en tabaksproducten

Chemie

Basischemie

Eindproducten chemie

Kunststofverwerking

Metaal en elektrotechniek

Basismetaal

Metaalproducten

Machine-industrie

Elektrotechniek

Transportmiddelen

Overige industrie

Textiel

Hout- en bouwmaterialen

Papier

Grafische industrie

Energie

Bouw en onroerend goed

Bouw

Exploitatie van onroerend goed

Handel en reparatie

Transport en communicatie

Scheeps- en luchtvaart

Weg- en railvervoer

Communicatie

Bank- en verzekeringswezen

Bankwezen

Verzekeringswezen

Horeca en zakelijke dienstverlening

Zakelijke dienstverlening

116

Overige commerciële dienstverlening 
Tabel 6.5 (vervolg)

Relatieve tekorten aan employability per bedrijfssector

$\begin{array}{cc}\text { Bedrijfssector } & \begin{array}{c}\text { Relatieve tekorten } \\ \text { Index }\end{array}\end{array}$

$\begin{array}{lr}\text { Kwartaire diensten } & 98 \\ \text { Gezondheidszorg } & 99 \\ \text { Overige kwartaire diensten } & 102 \\ \text { Overheid en onderwijs } & 86 \\ \text { Onderwijs } & 72 \\ \text { Overheid } & 93\end{array}$

Bron: OSA/CBS/ROA

Omdat van enkele bedrijfssectoren helaas niet alle benodigde gegevens voorhanden zijn, is het niet mogelijk voor deze bedrijfssectoren te indiceren in hoeverre er relatieve tekorten bestaan aan werknemers met een goede employability ${ }^{15}$.

Nu duidelijk is geworden in hoeverre de aanwezige employability beantwoordt aan de behoefte aan employability is het van belang te bezien in hoeverre het gevaar van een, gezien de behoefte, geringe aanwezige employability wordt versterkt door een ongunstige arbeidsmarktsituatie en een beperkte aanwezigheid van effectueringscondities. Om dit te kunnen bepalen worden de indexcijfers voor de aanwezige employability, de behoefte aan employability, de arbeidsmarktsituatie en de effectueringscondities elk afzonderlijk vermenigvuldigd met het aantal variabelen dat is gebruikt bij het bepalen van de indexcijfers bij de betreffende employability-dimensie. Het indexcijfer voor de aanwezige individuele employability binnen een sector wordt dus vermenigvuldigd met dertien, het behoefte-indexcijfer met zes, het indexcijfer voor arbeidsmarktperspectieven met één en het effectueringsconditie-indexcijfer met acht. De som van deze afzonderlijke producten wordt vervolgens gedeeld door achtentwintig om te komen tot de in de laatste kolom van tabel 6.6 vermelde Sectorale Employability Indexcijfers. Deze methode is gebruikt om ervoor te zorgen dat elke individuele variabele even zwaar meetelt in de eindindex. Vanzelfsprekend is er daarbij voor gezorgd dat een hoger indexcijfer een gunstigere situatie betekent. Hiervoor moesten de behoefte indexcijfers worden herberekend, zodat een hoog indexcijfer een geringe behoefte betekent. De confrontatie van de behoefte, de aanwezige employability, de arbeidsmarktsituatie en de effectueringscondities levert per bedrijfssector een indexcijfer op. In tabel 6.6, wordt een overzicht gegeven van de indexcijfers voor de verschillende bedrijfssectoren. Het dient nogmaals gezegd dat het hierbij gaat om indicerende cijfers en niet om een waarde-oordeel.

15. Het tekort aan werknemers met een goede employability in een sector moet niet worden verward met de mate waarin zich in die sector arbeidsmarktknelpunten voordoen. 


\subsection{Employability Index voor niet-werkenden}

In deze paragraaf wordt op basis van de gegevens in hoofdstuk 5 de Employability Index voor niet-werkenden geconstrueerd. De index wordt, mede op basis van het in het conceptuele model in hoofdstuk 2 aangereikte raamwerk, geconstrueerd in drie stappen:

Stap 1: De individuele employability per bedrijfssector.

Stap 2: De arbeidsmarktsituatie voor niet-werkenden op korte termijn.

Stap 3: Constructie van de samenvattende Employability Index.

De data die nodig zijn voor een verbijzondering naar de verschillende in hoofdstuk 2 aangereikte categorieën niet-werkenden zijn voor deze eerste invulling van de Monitor niet beschikbaar. Enkele van de onderzochte databronnen, waaronder de EBB, bieden echter voldoende mogelijkheden om in de toekomst een aparte index te creëren voor niet-participerenden en niet-werkende werkzoekenden. Een verdere verbijzondering van de groep niet-participerenden naar niet-participerende vijftigplussers, niet-participerenden met een werkende partner en niet-participerenden met een arbeidshandicap lijkt veel beter te kunnen als de EBB vragenlijst op een aantal punten wordt aangepast. Niettemin is zo goed mogelijk getracht voor de verschillende categorieën niet-werkenden een index op te stellen. Deze moet echter met de nodige terughoudendheid worden behandeld. Met name voor niet-participerende vijftigplussers en niet-participerenden met een arbeidshandicap zijn nog te weinig data voorhanden.

Omdat er nog te weinig informatie beschikbaar is over de mate waarin niet-werkenden gebruik kunnen maken van de institutionele en fiscale maatregelen en de door verschillende instanties geboden faciliteiten kan bij de constructie van de uiteindelijke Employability Index voor niet-werkenden geen rekening meer worden gehouden met de effectueringscondities. In de toekomst zou dit wel tot de mogelijkheden behoren, mits informatie beschikbaar komt omtrent de bekendheid van groepen nietwerkenden en werkgevers met bepaalde regelingen en faciliteiten en de mate waarin niet-werkenden met een bepaalde opleidingsachtergrond gebruik (kunnen) maken van de bestaande faciliteiten.

Bij de constructie van de Employability Index voor niet-werkenden is verbijzonderd naar opleidingsniveau. Ook hierbij geldt dat een verdere verbijzondering naar bijvoorbeeld 18 opleidingssectoren vooralsnog niet tot de mogelijkheden behoort, gezien het geringe aantal waarnemingen per opleidingssector dat in dat geval resteert. Het gebruik van EBB data in de toekomst zou een dergelijke verbijzondering echter wel mogelijk maken. 


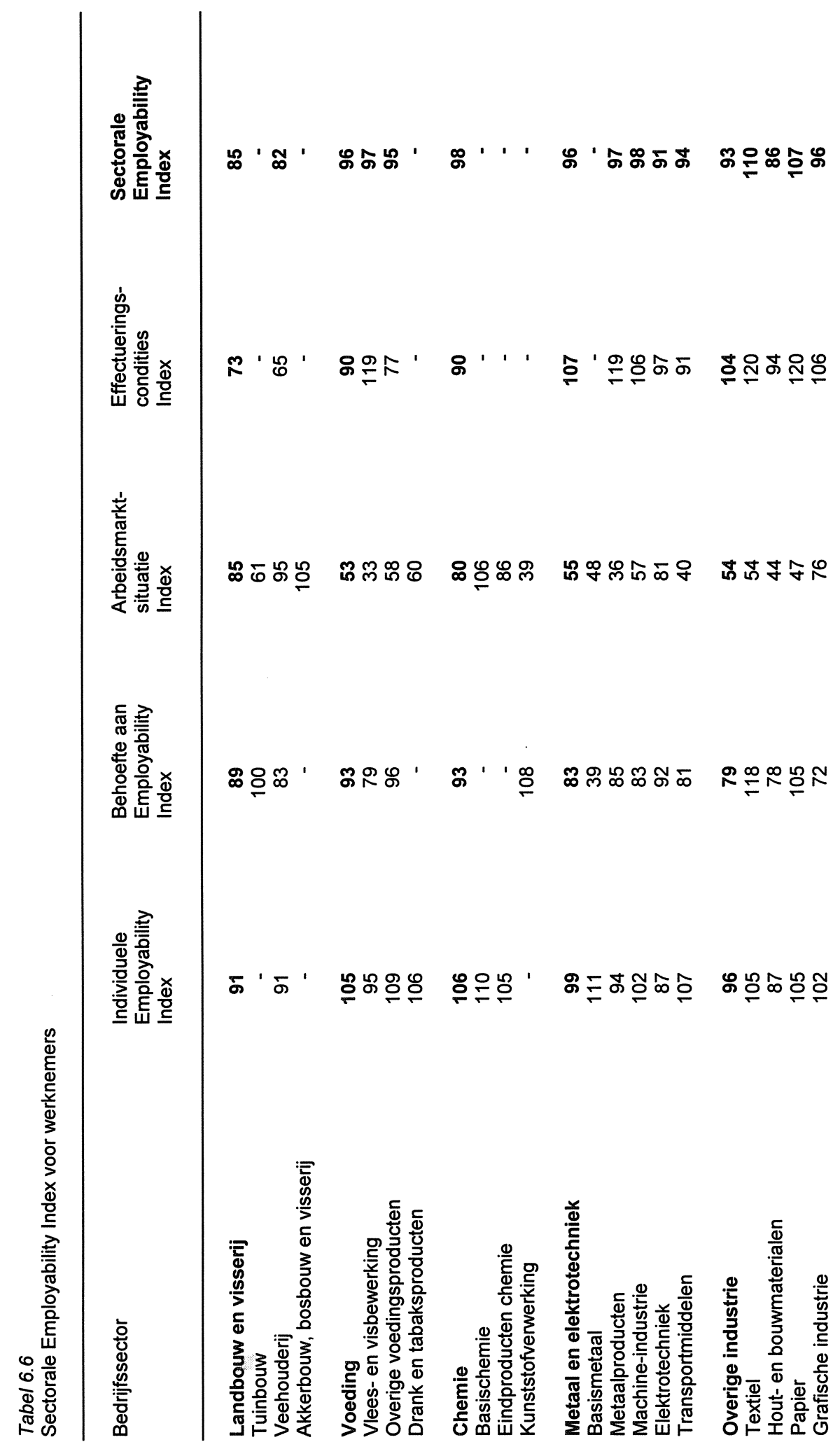




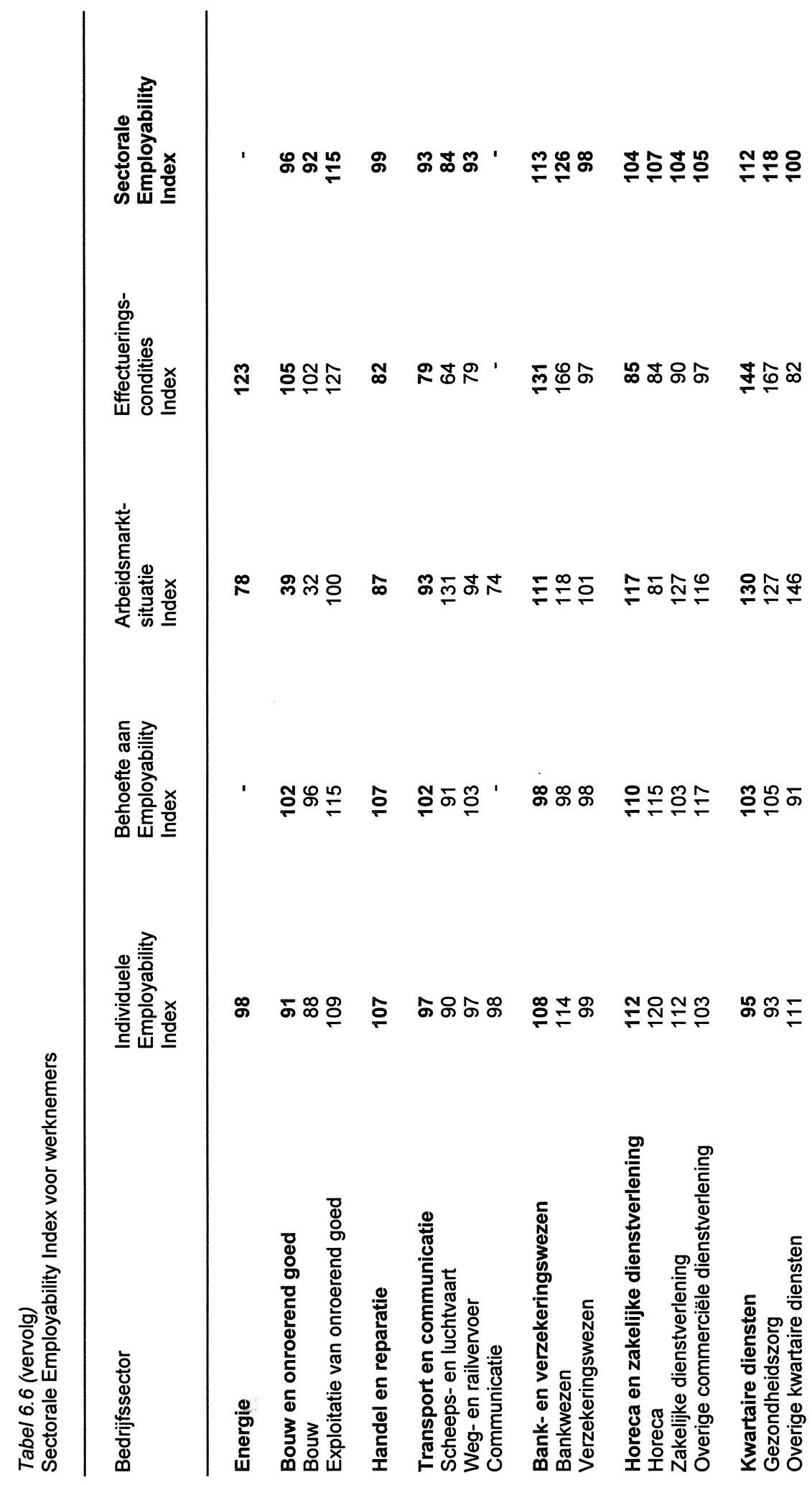




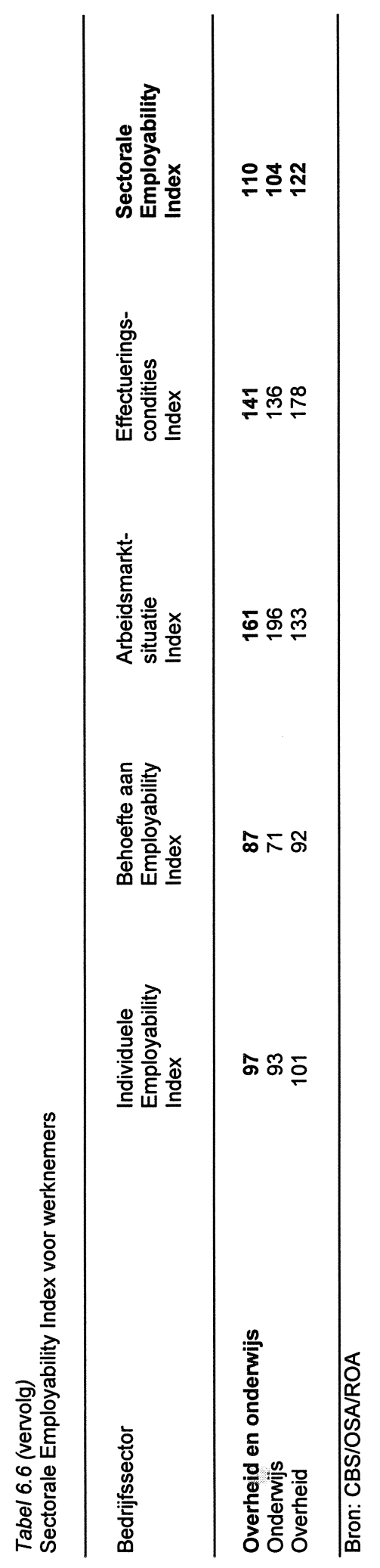




\section{Stap 1: de individuele employability}

Allereerst wordt in stap 1 bepaald in hoeverre groepen niet-werkenden employable zijn. Hierbij wordt evenals bij de werknemers gekeken naar een viertal centrale aspecten: Vermogen, Bereidheid, Inspanning en Persoonlijke belemmering. De scores van de niet-werkenden op deze vier aspecten worden aan de hand van een of meerdere variabelen bepaald. Het employability-vermogen van de groepen niet-werkenden wordt bijvoorbeeld bepaald door te kijken naar het competentieniveau, de periode waarin men geen betaald werk heeft verricht en het opleidingsvermogen.

Bij de constructie van de uiteindelijke individuele Employability Index voor de verschillende groepen niet-werkenden wordt aan de vier afzonderlijke aspecten een gelijk gewicht toegekend. Vooralsnog worden de scores op de volgende variabelen meegenomen bij het bepalen van de individuele employability van de verschillende groepen niet-werkenden:

- Vermogen ${ }^{16}$ :

- competentieniveau (tabel 5.1);

- werkloosheidsduur (tabel 5.6);

- opleidingsvermogen (afgeleid van tabel 5.1).

- Bereidheid $^{17}$ :

- geografische mobiliteitsbereidheid (tabel 5.10);

- bereidheid tot een brede kwantitatieve inzet (tabel 5.11).

- Inspanning ${ }^{18}$.

- opleidingsinspanning (tabel 5.13).

- Persoonlijke belemmeringen ${ }^{19}$ :

- gezinssituatie (tabel 5.15);

- arbeidshandicap (tabel 5.16).

In tabel 6.7 wordt een zo compleet mogelijk beeld geschetst van de individuele employability van niet-werkenden, verbijzonderd naar categorie niet-werkenden en

16. Voor niet-werkende werkzoekenden zijn werkloosheidsduur en intredevermogen (tabel 5.7) als variabelen gebruikt. Voor de verschillende groepen niet-participerenden kon alleen werkloosheidsduur als variabele worden gebruikt.

17. Voor niet-werkende werkzoekenden is ook functionele mobiliteitsbereidheid (tabel 5.9) als variabele gebruikt. Voor de totale groep niet-participerenden kon de bereidheid tot een brede kwantitatieve inzet niet worden gebruikt. Wel is gebruik gemaakt van de variabele intredebereidheid (tabel 5.8).

18. Voor de niet-werkende werkzoekenden is behalve opleidingsinspanning ook naar intredeinspanning en inspanning op het gebied van de kwantitatieve inzetbaar had gekeken (tabellen 5.12 en 5.14).

19. Voor de niet-participerende vijftigplussers is het vooralsnog niet mogelijk de variabele arbeidshandicap in de analyse mee te nemen. Voor deze categorie is derhalve alleen de gezinssituatie gebruikt. 
opleidingsniveau. De verschillende indexcijfers zijn zodanig geconstrueerd dat de situatie voor de niet-werkende gunstiger wordt naarmate het indexcijfer hoger is.

\section{Stap 2: arbeidsmarktsituatie voor niet-werkenden}

In stap 2 wordt de arbeidsmarktsituatie voor niet-werkenden onder de loep genomen. Hierbij is slechts één variabele van belang, namelijk het percentage niet-werkenden waarvoor op grond van hun opleidingsachtergrond op korte termijn goede tot zeer goede arbeidsmarktperspectieven bestaan. In tabel 6.8 wordt het bijbehorende indexcijfer vermeld. 


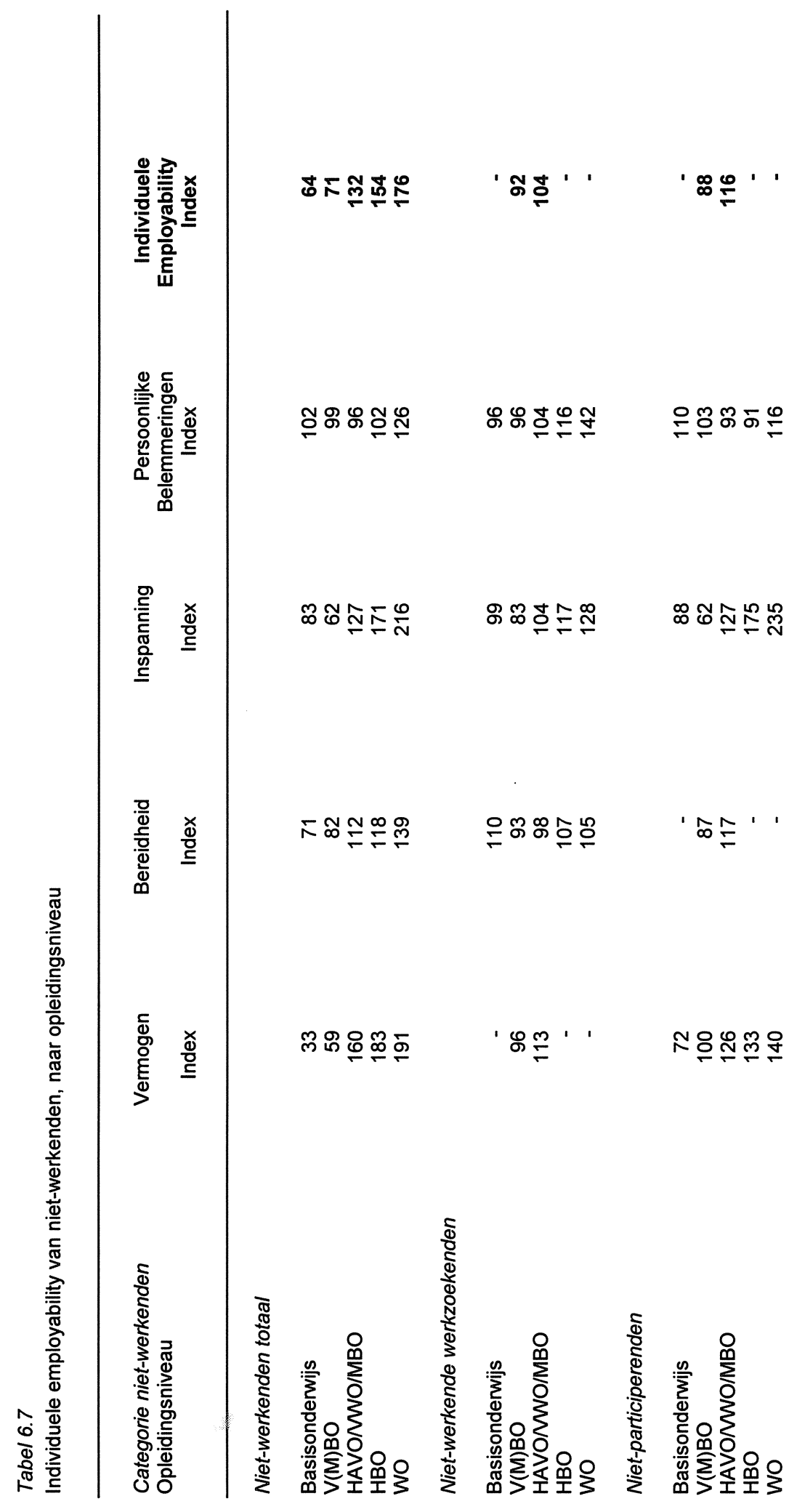




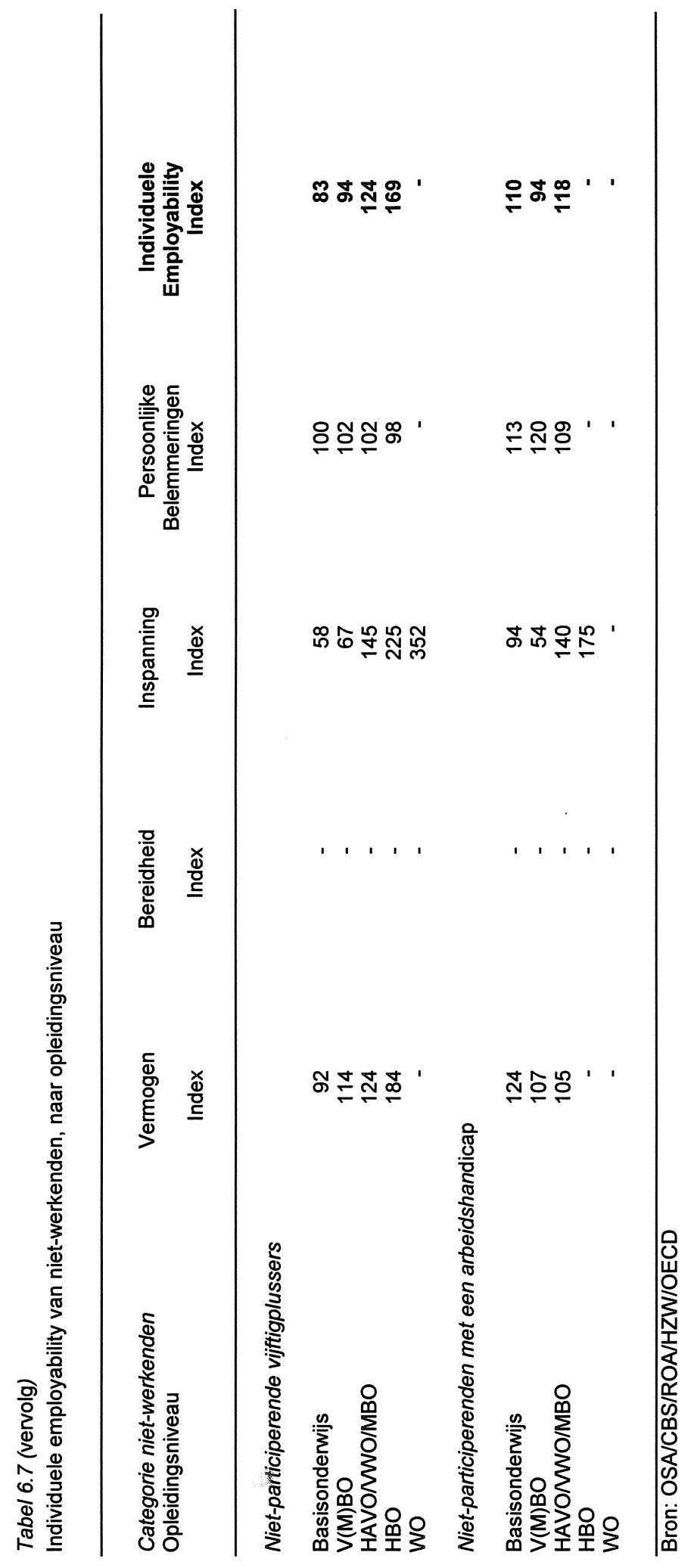


Tabel 6.8

Arbeidsmarktperspectieven van niet-werkenden, naar opleidingsniveau

Categorie niet-werkenden

Opleidingsniveau

(Zeer) goede arbeidsmarktperspectieven Index

Niet-werkenden

Basisonderwijs

$\mathrm{V}(\mathrm{M}) \mathrm{BO}$

HAVO/WO/MBO

HBO

WO

$$
\begin{array}{r}
0 \\
8 \\
95 \\
170 \\
179
\end{array}
$$

Bron: OSA/CBS/ROA/HZW/OECD

Stap 3: constructie van de samenvattende Employability Index

In stap 3 komen tabel 6.7 en 6.8 samen om een compleet beeld te geven van de employability van niet-werkenden. Gezien de zeer beperkte beschikbaarheid van data die op grond van het in hoofdstuk 2 voorgestelde conceptuele model nodig zijn om een compleet beeld te krijgen van de employability van niet-werkenden is het van belang dat de in tabel 6.9 weergegeven indices voor de niet-werkende werkzoekenden, de niet-participerenden, de niet-participerende vijftigplussers en de niet-participerenden met een arbeidshandicap met de nodige terughoudendheid worden behandeld. Bovendien is het als gevolg van het feit dat aan de verschillende indices verschillende variabelen ten grondslag liggen niet mogelijk de vijf gepresenteerde indices onderling met elkaar te vergelijken. Bij de constructie van de verschillende indices is er net als bij de werkenden voor gezorgd dat elke onderliggende variabele even zwaar meetelt.

Tabel 6.9

Employability Index voor niet-werkenden, naar opleidingsniveau

\begin{tabular}{lccc}
\hline $\begin{array}{l}\text { Categorie niet-werkenden } \\
\text { Opleidingsniveau }\end{array}$ & $\begin{array}{c}\text { Individuele } \\
\text { Employability } \\
\text { Index }\end{array}$ & $\begin{array}{c}\text { Arbeidsmarkt } \\
\text { perspectieven } \\
\text { Index }\end{array}$ & Employability \\
\hline
\end{tabular}

Niet-werkenden

Basisonderwijs

$\mathrm{V}(\mathrm{M}) \mathrm{BO}$

HAVO/WWO/MBO

HBO

WO

$\begin{array}{rr}0 & 57 \\ 8 & 64 \\ 95 & 128 \\ 170 & 155 \\ 179 & -\end{array}$

Niet-werkende werkzoekenden

Basisonderwijs

$\mathrm{V}(\mathrm{M}) \mathrm{BO}$

$\begin{array}{rr}0 & 82 \\ 8 & 103 \\ 95 & - \\ 170 & -\end{array}$

HBO

WO 
Tabel 6.9 (vervolg)

Employability Index voor niet-werkenden, naar opleidingsniveau

\begin{tabular}{lccc}
\hline $\begin{array}{l}\text { Categorie niet-werkenden } \\
\text { Opleidingsniveau }\end{array}$ & $\begin{array}{c}\text { Individuele } \\
\text { Employability } \\
\text { Index }\end{array}$ & $\begin{array}{c}\text { Arbeidsmarkt } \\
\text { perspectieven } \\
\text { Index }\end{array}$ & Employability \\
\hline
\end{tabular}

Niet-participerenden

Basisonderwijs

$\mathrm{V}(\mathrm{M}) \mathrm{BO}$

HAVO/MWO/MBO

HBO

WO

$\begin{array}{rr}88 & 0 \\ 116 & 8 \\ - & 95 \\ - & 170\end{array}$

Niet-participerende vijftigplussers

Basisonderwijs

$\mathrm{V}(\mathrm{M}) \mathrm{BO}$

HAVONWO/MBO

179

HBO

WO

83
94
124
169

0

62
72

117

Niet-participerenden met een handicap

Basisonderwijs

$\mathrm{V}(\mathrm{M}) \mathrm{BO}$

170

179

117

HAVO/WWO/MBO

HBO

WO

$\begin{array}{rrr}110 & 0 & 83 \\ 94 & 8 & 72 \\ 118 & 95 & 113 \\ - & 170 & - \\ - & 179 & -\end{array}$

Bron: OSA/CBS/ROA/HZW/OECD 


\section{Verdere ontwikkeling van de Employability Monitor}

\subsection{Lacunes in de beschikbare informatie}

In figuur 7.1 is in het kort weergegeven wat de belangrijkste lacunes zijn in de tot nu toe beschikbare data voor de Employability Monitor voor zowel werkenden als nietwerkenden. In de figuur worden de aangetroffen lacunes bij het inrichten van een eerste Employability Monitor aangegeven. Daarnaast wordt aangegeven op welke wijze in deze lacunes zou kunnen worden voorzien. In een aantal gevallen zou met een eenvoudige verandering in de routing van een vragenlijst kunnen worden volstaan om een lacune weg te werken. In andere gevallen is het mogelijk door extra vragen op te nemen in bestaande vragenlijsten of door bepaalde vragen anders te stellen te voorzien in een nog openstaande informatiebehoefte.

Een van de grootste lacunes in de eerste opzet van de Employability Monitor voor zowel werknemers, als niet-werkenden, is het ontbreken van informatie over de mate waarin mensen beschikken over de voor hun employability essentiële vakspecifieke expertise en wat wel wordt aangeduid als de 'key-skills' voor de kennisintensieve samenleving. In het Verenigd Koninkrijk is in 1997 in kaart gebracht in hoeverre werkenden over deze competenties beschikken en in hoeverre bepaalde competenties vereist zijn voor het adequaat uitoefenen van hun huidige baan. Dit 'Skills Survey' zal binnenkort weer worden herhaald.

In het in 1999 in opdracht van het Ministerie van Sociale Zaken en Werkgelegenheid door ons uitgevoerde onderzoek onder medewerkers van ABP/USZO zijn soortgelijke vragen gesteld (zie Borghans, c.s., 2000). Bovendien is in dit onderzoek gevraagd of het werk dat men doet de afgelopen jaren veranderd is door technologische en organisatorische ontwikkelingen en op welke wijze men de in verband met deze ontwikkelingen vereiste competenties heeft verworven.

Gezien de centrale rol die de competenties van werkenden en niet-werkenden spelen voor hun employability, is het gewenst ook in Nederland een soortgelijke Competentie-Enquête op te zetten. In paragraaf 7.2 zal hierop nader worden ingegaan.

\subsection{Naar een periodieke Employability Monitor}

In de hoofdstukken 4 en 5 van dit rapport is aangegeven op welke wijze op basis van de momenteel beschikbare databronnen een eerste invulling aan een Employability Monitor voor werkenden en niet-werkenden kan worden gegeven. In deze paragraaf zal worden aangeven op welke wijze dit zou kunnen worden uitgebouwd tot een periodieke monitoring van de verschillende aspecten van de employability van werkenden en niet-werkenden. 


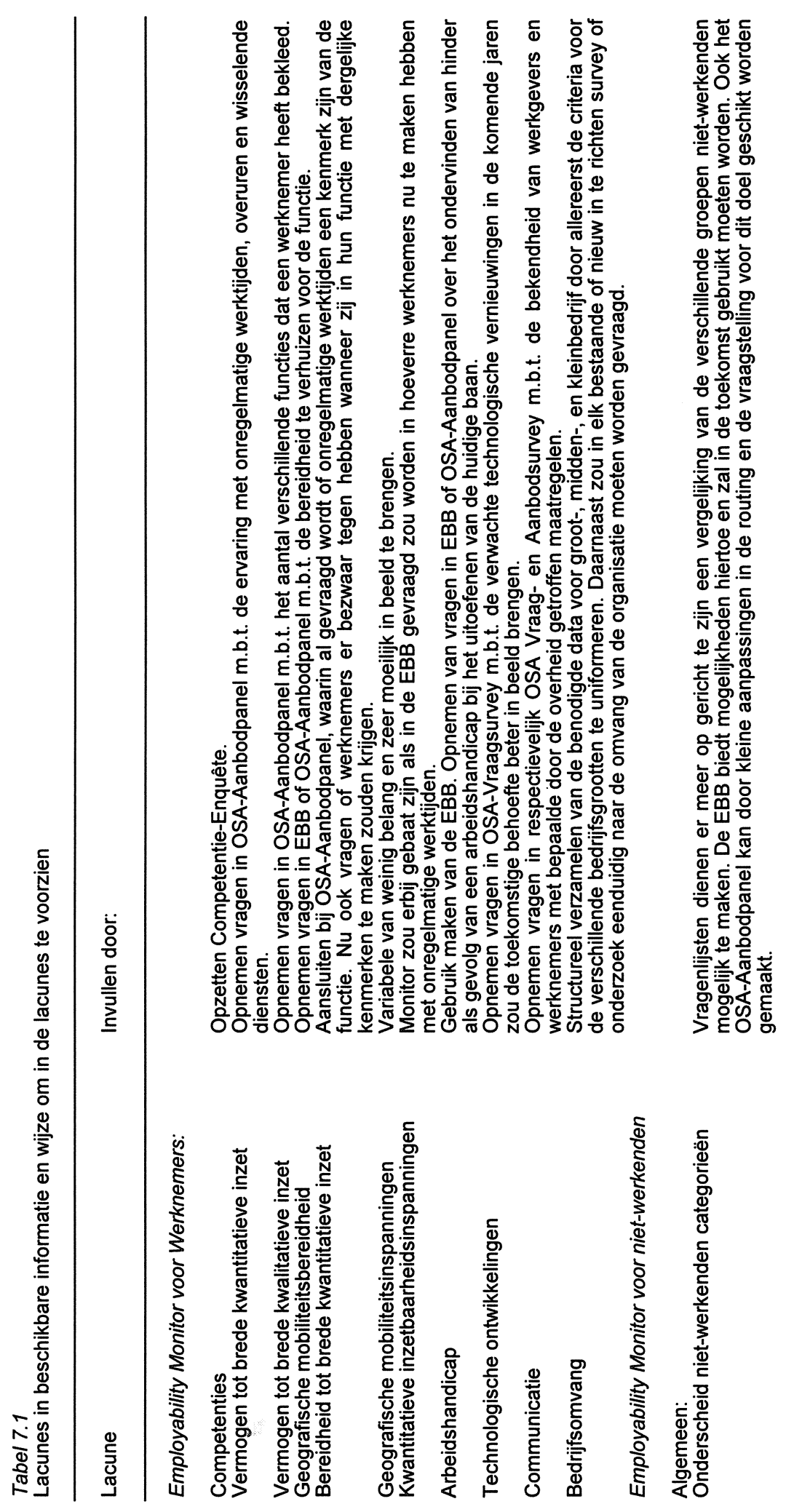




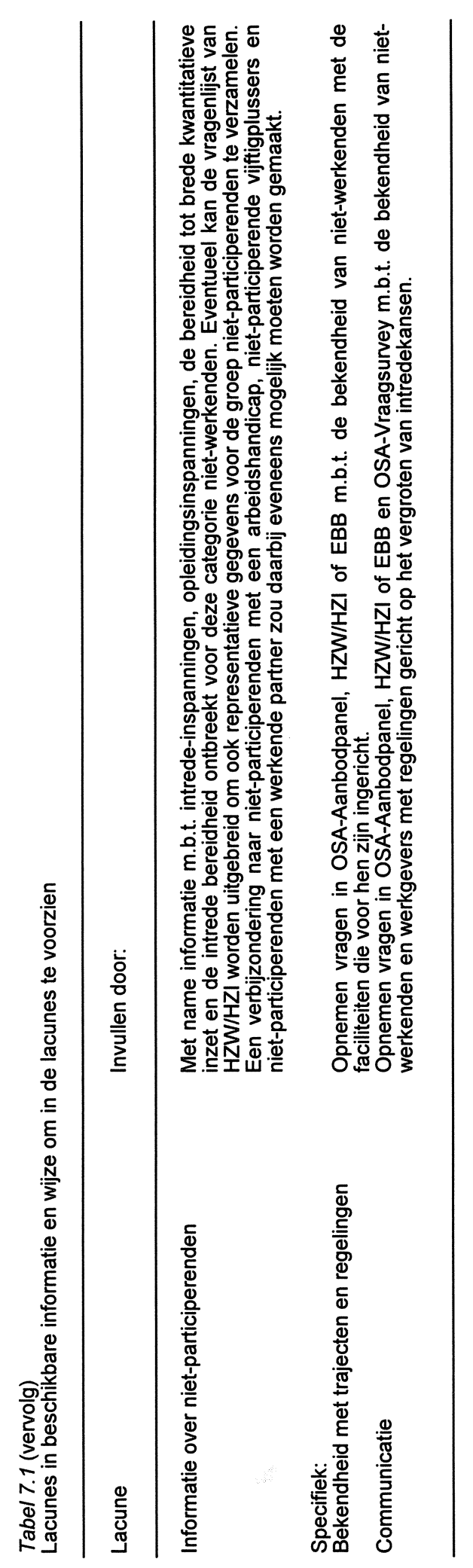


Uitgangspunt daarbij is dat de lijn die in de in dit rapport gepresenteerde eerste opzet van de Employability Monitor wordt voorgesteld, wordt gevolgd. Dit betekent dat de monitoring van de verschillende aspecten van de employability van werkenden en niet-werkenden betrekking zal hebben op groepen van mensen, waarbij gebruik gemaakt wordt van geaggregeerde data.

Een verdergaande mogelijkheid is, zoals in hoofdstuk 1 reeds werd aangestipt, het registreren van employability-kenmerken van individuen. Dit laatste zou met name een mogelijkheid zijn voor de monitoring van de employability van geregistreerde werkzoekenden in het kader van de gegevensverzameling ten behoeve van de 'sluitende aanpak', die erop gericht is de arbeidsmarktintrede van niet-werkende arbeidskrachten te vergemakkelijken. Een dergelijke registratie overstijgt echter het kader van een Employability Monitor en zal derhalve hier ook niet verder worden uitgewerkt.

Voor een periodieke monitoring van de employability van werkenden en niet-werkenden kan worden aangesloten bij de in dit rapport geschetste werkwijze. Zoals in de vorige paragraaf is aangegeven bestaan er echter op verschillende onderdelen van de voorgestelde Employability Monitor lacunes in de beschikbare informatie. Voor een deel zouden deze lacunes kunnen worden opgevuld door een aantal aanvullende vragen te stellen in bestaande surveys. Op deze wijze zou de Employability Monitor op diverse punten kunnen worden verrijkt en bijvoorbeeld ook voor het midden- en kleinbedrijf worden ingericht. Een veel verdergaande invulling van de Employability Monitor zou kunnen worden gerealiseerd door het opzetten van een competentie-enquête en een uitgebreide cohortstudie. Bovendien zou een aparte studie moeten worden uitgevoerd, die gericht is op de monitoring van de employability van de 'stille reserve', omdat van die groep niet-werkenden tot nu toe weinig bekend is omtrent hun afstand tot de arbeidsmarkt en daarmee ook hun intredekans. Hieronder zullen de basisoptie voor een Employability Monitor en de drie genoemde nieuw op te zetten enquête-onderzoeken nader worden uitgewerkt.

\section{Employability Monitor}

Om aan een periodieke actualisering van de Employability Monitor vorm te geven, is het belangrijk dat er ruimte komt voor het verder verbeteren van de monitor op basis van de nieuw beschikbaar komende informatie over de verschillende aspecten van de employability van werkenden en niet-werkenden. Bovendien is het belangrijk dat er aandacht kan worden gegeven aan nadere analyses van de achtergronden van de gesignaleerde opvallende ontwikkelingen in bepaalde bedrijfssectoren of de employability-problemen bij bepaalde groepen werkenden of niet-werkenden. Ten slotte zal er voor moeten worden gezorgd dat de Employability Monitor zich ontwikkelt tot een aansprekende rapportage. Dit vereist dat de veelheid aan cijfers die wordt gepresenteerd wordt aangevuld met meer kwalitatieve informatie en eventuele op een bepaald aspect van de employability van werkenden of niet-werkenden toegespitste analyses. 
Zoals uit de presentatie van de beschikbare gegevens voor het in kaart brengen van de verschillende aspecten van de employability van werkenden en niet-werkenden blijkt, hebben we in deze eerste opzet gebruik gemaakt van databronnen die betrekking hebben op verschillende kalenderjaren. Dit is met name het gevolg van het feit dat sommige data, zoals bijvoorbeeld het International Adult Literacy Survey (vooralsnog), slechts eenmalig zijn verzameld. De meeste belangrijke databronnen worden echter jaarlijks (EBB) of tweejaarlijks (OSA-aanbod- en vraagpanel) geactualiseerd. Hierdoor is het in principe mogelijk de Employability Monitor jaarlijks of tweejaarlijks te actualiseren.

Gezien de aard van de verzamelde informatie mag echter niet verwacht worden dat er op de meeste aspecten van de employability van werkenden en niet-werkenden in één jaar grote veranderingen optreden. Daarom wordt voorgesteld de Employability Monitor tweejaarlijks te actualiseren.

Om de tweejaarlijkse rapportage van de Employability Monitor tot een aansprekend rapport te maken, is het wenselijk om de gepresenteerde kwantitatieve informatie aan te vullen met kwalitatieve informatie op basis van gesprekken met sleutelpersonen, beschrijvingen van best-practices, e.d. Ook kan gedacht worden aan een themahoofdstuk waarin verslag gedaan wordt van meer diepgaande analyses van relaties tussen competentie-ontwikkeling, kwalificatieveroudering, inzetbaarheid, mobiliteit en employability.

In het tussenliggende jaar zouden dan specifieke studies kunnen worden uitgevoerd naar bepaalde aspecten van de employability van werkenden en/of niet-werkenden (bijvoorbeeld kwalificatieveroudering, inzetbaarheid), of studies die nader ingaan op een specifieke bedrijfssector, of een specifieke probleemgroep (bijvoorbeeld lager opgeleiden of ouderen). Over deze onderzoeken kan in afzonderlijke rapporten worden gepubliceerd. Bovendien kunnen dergelijke verdiepende studies een belangrijke bijdrage leveren aan het verbeteren van de kwaliteit van de Employability Monitoren, en zouden ze de basis voor de analyses in het themahoofdstuk, of bepaalde 'kadertjes' in het eerstvolgende overzichtsrapport kunnen vormen.

\section{Competentie-Enquête}

De belangrijkste lacune in de momenteel beschikbare data op basis waarvan de employability van werkenden en niet-werkenden in beeld kan worden gebracht, heeft betrekking op informatie over de mate waarin mensen beschikken over de voor hun employability essentiële vakspecifieke expertise en 'key-skills' die cruciaal zijn voor hun employability. Daarbij is het overigens ook van groot belang meer inzicht te krijgen in de competenties die essentieel zijn voor de verschillende groepen werkenden en niet-werkenden.

Niet alleen is er geen informatie beschikbaar over de competenties van mensen die het initiële onderwijs hebben verlaten. Ook wordt het steeds belangrijker om inzicht te hebben in de ontwikkeling van de kennis en vaardigheden van werkenden en nietwerkenden en om te weten hoe deze competenties worden benut. 
Om adequate informatie te krijgen over de competenties waarover werkenden en niet-werkenden beschikken, zou een nieuwe periodiek te houden enquête moeten worden opgezet. Hierbij kan het Britse 'Skills Survey' min of meer als een voorbeeld worden gezien. Dit temeer daar het - vanwege de competentietoetsen erg kostbare - International Adult Literacy Survey vooralsnog in Nederland niet zal worden herhaald.

Het Britse Skills Survey of the Employed British Workforce en de International Adult Literacy Survey van de OECD zijn momenteel de enige databronnen die dergelijke informatie verschaffen. Uit het onderzoek dat inmiddels met deze bronnen is verricht wordt duidelijk dat dergelijk data een belangrijke bijdrage kunnen leveren aan de inzichten die we hebben over de rol van kennis op de arbeidsmarkt. In de nieuwe enquête die in het Verenigd Koninkrijk in 2001 wordt gehouden zullen circa 4.000 werkenden worden geënquêteerd. Voor een in Nederland te houden CompetentieEnquête zou de voorkeur uitgaan naar een wat grotere steekproefomvang van $\mathbf{5 . 0 0 0}$ respondenten. Deze steekproefomvang is nodig om een tweetal redenen. In de eerste plaats, omdat, in tegenstelling tot de enquête in het Verenigd Koninkrijk, naast de werkenden ook de niet-werkenden zullen moeten worden bevraagd. In de tweede plaats, omdat ten behoeve van de Employability Monitor een uitsplitsing naar bedrijfssector vereist is, terwijl ook een verbijzondering naar beroepssegment of opleidingsachtergrond wenselijk zou zijn.

Wij stellen voor jaarlijks 5.000 mensen te bevragen. Gezien de omvang en de aard van de te stellen vragen zal het hier moeten gaan om een 'face-to-face' enquête. Van de 5.000 mensen die worden bevraagd, zouden er 1.000 betrekking kunnen hebben op een specifieke groep, waarop in een bepaald jaar wordt ingezoomd. De resterende 4.000 ondervraagden zorgen dan voor de representativiteit ten aanzien van de samenstelling van de potentiële beroepsbevolking. De 'oversampling' van een specifieke groep werkenden of niet-werkenden kan zich bijvoorbeeld richten op groepen in de samenleving waarbij mogelijk sprake is van kwalificatieveroudering (bijvoorbeeld werklozen, herintreders, of ouderen).

Een dergelijke opzet van de competentie-enquête biedt een breed scala aan mogelijkheden om het maatschappelijk inzicht in de competentie-ontwikkeling en employability van werkenden en niet-werkenden te vergroten. Zo is het, door bij de te benaderen specifieke doelgroep af te wijken van het normale steekproefpatroon, ook mogelijk om bijvoorbeeld in een aantal bedrijven binnen een bepaalde sector meerdere werknemers te ondervragen, om zo de relatie tussen bedrijfsbeleid en competenties te kunnen onderzoeken. Een groot voordeel van een dergelijke aanpak is dat de gegevens over de specifieke doelgroep steeds in het perspectief van de gehele arbeidsmarkt kunnen worden geplaatst.

Jaarlijks zou dit specifieke deel van de steekproef vanuit een andere invalshoek kunnen worden ingevuld. Dit biedt ook goede mogelijkheden voor de dataverzameling ten behoeve van de verdiepende studies in het kader van de Employability Monitor. 
Ook is het mogelijk om een bestaande cohort-studie eenmalig in te lijven in de enquête. Dit heeft als groot voordeel dat de longitudinale gegevens over een bepaald cohort kunnen worden gerelateerd aan de algehele arbeidsmarktsituatie op dat moment van de gehele beroepsbevolking.

Naast een afwijkende steekproef voor een deel van de onderzoekspopulatie kan ook in aanvulling op de enquête een deel van de respondenten verder worden ondervraagd of getest. Dit geeft de mogelijkheid om aanvullende gedetailleerdere informatie over specifieke deelgroepen te verwerven. De gegevens die beschikbaar zijn gekomen in de reguliere enquête kunnen gebruikt worden als steekproefkader voor verder onderzoek, waardoor een zeer subtiele steekproeftrekking mogelijk is, bijvoorbeeld iedereen die aangeeft moeite te hebben met het omgaan met computers. Binnen dit kader valt ook de mogelijkheid om een deelgroep na verloop van tijd opnieuw te benaderen, maar ook interessant is de optie om in aanvulling op de persoonsenquête, een interview af te nemen bij de betreffende werkgever (of de directe baas) om zo aan elkaar te relateren gegevens van de werknemer en de werkgever te verkrijgen.

\section{Cohortstudie}

De in dit hoofdstuk voorgestelde Employability Monitor geeft, zoals reeds is opgemerkt, slechts een dwarsdoorsnede van de employability van de werkenden in de verschillende bedrijfssectoren en de niet-werkenden. Een dergelijke periodieke monitoring van de employability geeft weliswaar een algemeen beeld van de employability van de potentiële beroepsbevolking, maar het geeft geen inzicht in de wijze waarop de employability van individuele mensen zich ontwikkelt en door welke factoren iemands employability zich in gunstige of ongunstige zin ontwikkelt. Om dergelijke ontwikkelingen in beeld te kunnen brengen is een longitudinaal onderzoek gewenst, waarin mensen in de tijd worden gevolgd. Een efficiënte mogelijkheid om dergelijke informatie over de ontwikkeling van verschillende aspecten van de employability op individueel niveau te kunnen genereren, is het opnieuw benaderen van mensen die in het verleden in een bepaalde cohort-studie zijn geënquêteerd. Een interessante mogelijkheid in dit verband is het opnieuw benaderen van het SMVO-cohort van het CBS. In dit schoolloopbaanonderzoek van het CBS is in 1977 de schoolloopbaan vastgelegd van circa 37.000 leerlingen die in dat jaar in het voortgezet onderwijs starten. Bovendien is deze leerlingen een intelligentietoets afgenomen (van Herpen en Thijssen, 1983). Bij het al dan niet verlaten van het volledig dagonderwijs zijn deze leerlingen in het kader van het CBS schoolverlatersonderzoek tussen 1981 en 1987 opnieuw geënquêteerd. In 1987 is dit schoolverlatersonderzoek echter stopgezet, waardoor alleen informatie beschikbaar is over degenen die maximaal 7 jaar voortgezet onderwijs hebben gevolgd (Meesters, 1992).

De toentertijd benaderde scholieren zijn thans circa 36 jaar oud. Wanneer uit het SMVO-bestand een representatieve steekproef zou worden getrokken, die geënquêteerd zou worden over hun loopbaan, de gevolgde aanvullende scholing, motivatie, attitudes, e.d., zou een longitudinaal databestand beschikbaar kunnen komen, 
op basis waarvan een goed beeld zou kunnen worden verkregen van de relaties tussen de capaciteiten waarover iemand beschikt, de gevolgde initiële opleiding en aanvullende scholing, iemands motivatie en attitudes, loopbaanontwikkeling en employability. Het is vooralsnog echter niet duidelijk of het mogelijk is het eerdere SMVO-cohort opnieuw te bevragen. Overigens heeft een cohortstudie als nadeel dat slechts een beeld wordt gekregen van de employability van mensen die in één bepaald jaar zijn geboren. Daardoor ontbreekt het inzicht in de employability ontwikkeling van andere leeftijdsgroepen.

\section{Employability niet-participerenden}

Gezien de vele lacunes die zijn aangetroffen in de eerste opzet van de Employability Monitor voor niet-participerenden en het, gezien de krapte op de arbeidsmarkt, grote belang van inzicht in de employability van deze groep potentiële werknemers lijkt het wenselijk volgens het raamwerk, zoals dat in hoofdstuk 2 werd aangereikt, een instrument te ontwikkelen om employability van de 'stille reserve' in beeld te krijgen. Daarmee zou de monitoring van de employability van de vooropgestelde doelgroep kunnen worden gerealiseerd. Hierbij is het niet strikt noodzakelijk dat een aparte enquête wordt opgezet, maar kan waarschijnlijk vrij eenvoudig worden aangesloten bij de vragenlijsten die zijn ontwikkeld in het kader van het 'Hoe Zoeken Werkzoekenden'- en het 'Hoe Zoeken Ingeschrevenen'-onderzoek dat jaarlijks door Arbeidsvoorziening wordt gehouden. Door de onderzoeksgroep uit te breiden met nietparticiperenden, die bovendien nooit ingeschreven hebben gestaan zou vrij gemakkelijk betrouwbare informatie kunnen worden verzameld over deze groep nietwerkenden. Aansluiten bij de EBB door een extra module toe te voegen zou de mogelijkheden voor een Employability Monitor gericht op niet-participerenden vergroten. De vragen die hierin centraal zouden moeten staan worden onderscheiden in tabel 7.1. Met name de groep niet-participerenden zou in volgende golven van de EBB meer aandacht moeten krijgen. 


\section{Literatuur}

Arbeidsinspectie (1999a), Voorjaarsrapportage CAO-Afspraken 1999. Arbeidsinspectie, Den Haag.

Arbeidsinspectie (1999b), Najaarsrapportage CAO-Afspraken 1999. Arbeidsinspectie, Den Haag.

Arbeidsinspectie (2000), Voorjaarsrapportage CAO-afspraken 2000. Arbeidsinspectie, Den Haag.

Becker, G.S. (1964), Human Capital. A theoretical and empirical analysis, with special reference to education, National Bureau of Economic Research (NBER), New York

Borghans, L. C.s. (2000), Organisatieveranderingen en competentie-ontwikkeling; Verslag van een enquête bij het Kantoor, ROA-R-2000/3, Maastricht.

Eijs, van P. en A. de Grip (1999), De ontwikkeling van het project onderwijs arbeidsmarkt 19861998, ROA-W-1998/7.

Graaf, P.H. de en Luijckx, R. (1997), Structurele veranderingen, aspiraties en arbeidsmobiliteit, OSA, Den Haag.

Grip, A. de, L.F.M. Groot (1990), Technologische ontwikkelingen en opleidingseisen in het bankwezen, Tijdschrift voor Arbeidsvraagstukken, Volume 6, nr.3, pp. 67-77

Grip, A. de, J. Van Loo, J. Sanders (1998), Employability in bedrij: Naar een Employability Index voor bedrijfsectoren, ROA-R-1998/10, Maastricht.

Herpen, L.W. van, L.J.M. Thijssen (1983), Schoolloopbaan en herkomst van leerlingen in het voortgezet onderwijs, deel Il; cohort 1977, schoolkeuze, Staatsuitgeverij, Den Haag.

Meesters, M.J. (1992), Loopbanen in het ondenwijs en op de arbeidsmarkt (dissertatie), OOMOreeks (ITS), Nijmegen.

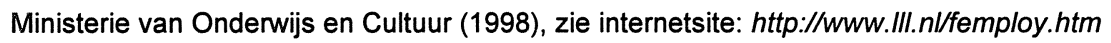

Ministerie van Sociale Zaken en Werkgelegenheid (1999), SZW-Werkgeverspanel, tabellenboek tweede meting, werkdocument nr. 128, Den Haag.

Ministerie van Sociale Zaken en Werkgelegenheid (1999), SZW-Werkgeverspanel, tabellenboek derde meting, werkdocument nr. 125, Den Haag.

Porter M.E. (1990), The competitive advantage of nations, Macmillan, London.

ROA (1999a), De Arbeidsmarkt naar Opleiding en Beroep tot 2004, ROA-R-1999/8, Maastricht.

ROA (1999b), De Arbeidsmarkt naar Opleiding en Beroep tot 2004, Statistische Bijlage, ROAR-1999/8b, Maastricht.

ROA (2000a), Werkgelegenheid en scholing 1999, ROA-R-2000/5, Maastricht.

ROA (2000b), Werkgelegenheid en scholing 1999, Statistische Bijlage, ROA-R-2000/5b, Maastricht.

Rojer, M.F.P., S.M. Pulleman (2000), Employability: een vergelijking tussen CAO's, Ministerie van Sociale Zaken en Werkgelegenheid, Den Haag.

Salthouse, T.A. (1994), Age related differences in basic cognitive processes: implications for work, Experimental aging research, vol. 20, no. 4, pp. 249-256. 
Stroeken, J.H.M. (1993), Informatietechnologie in het bankwezen, in: Horn, L.A. ten, J.H.M. Stroeken, F.R.H. Zijlstra (red.), Informatietechnologie in de maatschappij, wisselwerking, gebruik, sturing, Kluwer Bedrijfswetenschappen, Deventer.

Thijssen, J.G.L. (1989), Bedrijfsopleidingen als werkterrein: een oriëntatie, VUGA, Den Haag.

Thijssen, J.G.L. (1992), A model for adult training in flexible organizations. Journal of European Industrial Training, 16, (9), pp. 5-15.

Thijssen, J.G.L. (1997), Employability en employment: terminologie, modelvorming en opleidingspraktijk, Opleiding \& Ontwikkeling, nr. 10, pp. 9-14.

Verhaar, C.H.A., Smulders, H.R.M. en M.A.M. Meijs, van der (1999), Employability en scholing van werknemers in de agrarische sector, STOAS, Wageningen.

Vlasblom, J.D., B.J. Diephuis (2000), Methodiek voor korte-termijn arbeidsmarktprognoses op basis van een stromenmodel, ROA-W-2000/4, Maastricht.

Willemsen c.s. (2000), Kwantitatieve trends in personeelsbeleid, TNO, Hoofddorp.

Wong, R.A., E.C. Siegerist (1989), Schoolbaarheid: de resultaten van een oriënterend onderzoek naar de schoolbaarheid van werknemers en wat daarbij voor werkgevers en werknemers van belang kan zijn, OSA, Den Haag. 


\section{Appendix A Inventarisatie van de belangrijkste aan- dachtspunten}

In deze appendix wordt een beeld geschetst van de belangrijkste aandachtspunten, zoals die naar voren zijn gekomen tijdens de verschillende gesprekken 'in de markt'. De gesprekken hebben plaatsgevonden met hoofden P\&O- en HRM-specialisten van een klein aantal gerenommeerde ondernemingen in verschillende sectoren en met vertegenwoordigers van CNV, VNO/NCW (AWVN), FME/CWM, en Arbeidsvoorziening. Daarnaast is de Employability-problematiek door ons aan de orde gesteld in een gesprek met de Britse National Skills Task Force. Tevens is aansluiting gezocht bij bestaande publicaties en de in de verschillende segmenten van de arbeidsmarkt uitgevoerde onderzoeken om ook een goed en compleet beeld te krijgen van feitelijke inspanningen in de verschillende sectoren.

\section{Arbeidsvoorziening}

- Employability van werkzoekenden opvatten als de Intredekans.

- De Intredekans wordt geïndiceerd door de afstand tot de arbeidsmarkt.

- De afstand tot de arbeidsmarkt wordt voor werkzoekenden bepaald door gebruik te maken van bestaande instrumenten als de Kansmeter en de Kwint (Kwalificerende intake).

- Kansmeter bepaalt de fase waarin werkzoekende terechtkomt:

- Fase 1 direct bemiddelbaar;

- Nader te bepalen (Kwint bepaalt welke belemmeringen er bestaan en wat het traject is dat een werkzoekende zou moeten doorlopen om in te kunnen treden);

- Fase 4 Zeer moeilijk bemiddelbaar a.g.v. zware persoonlijke werkbelemmeringen.

- Kansmeter en Kwint worden weliswaar landelijk toegepast, maar landelijke databestanden zijn er (nog) niet.

- Variabelen die interessant zijn bij het monitoren van de employability van werkzoekenden:

Aanbodzijde: Arbeidsmarktkwalificaties (goed, redelijk, matig, slecht) in relatie tot bemiddelingsberoep o.b.v. opleiding en (hoeveel jaar opleiding, welke vakken, certificaten, stages) werkervaring (relevant, gering of geen).

Persoonlijke kwalificaties, variërend van goed, redelijk en matig tot slecht op basis van sollicitatiegedrag, presentatie, taal, flexibiliteit en belastbaarheid.

Vraagzijde: Op basis van wensberoep, laatst uitgeoefende beroep, stages etc. wordt het bemiddelingsberoep bepaald en op basis van korte termijn arbeidsmarktprognoses voor het bemiddelingsberoep wordt het Beroepsperspectief vastgesteld (slecht, matig, redelijk en goed). 
- Voor andere groepen, i.c. niet-participerenden (bijv. wao'ers), employability in beeld door gebruik te maken van gegevens omtrent wensen en vermogens op het gebied van mobiliteit, opleiding en inzetbaarheid aan de aanbodzijde en beroepsperspectief aan de andere kant.

- Mogelijk moet voor de employability van arbeidsongeschikten aansluiting worden gezocht bij het GAK en andere UVI's.

\section{Cap Gemini}

- Behoefte aan een monitor als deze een keurmerkfunctie zou krijgen vergelijkbaar met het Investors in People keurmerk.

- Sectorbreed in beeld brengen van employability-inspanningen levert problemen op omdat binnen de sector veel kleine IT-bedrijven alleen met detachering bezig zijn, waardoor er nauwelijks scholing plaatsvindt.

- De kracht van de IT-bedrijven is kennis, dus eigenlijk is alles wat er gebeurt employability-beleid.

- Het eigen Intranet wordt gebruikt door People managers. Het intranet bevat c.v.'s van medewerkers, op basis waarvan people managers projectteams kunnen samenstellen. Intranet is van groot belang om de in de organisatie aanwezige kennis en vaardigheden voor iedereen, op elk moment, zichtbaar te maken. Medewerkers zelf zijn verantwoordelijk voor het bijhouden van hun c.v. ('make your own destiny').

- Het functioneringsgesprek is gericht op het in beeld brengen van wensen van zowel de werknemer als de werkgever. In het gesprek komt dus ook aan de orde hoe business units zich ontwikkelen, wat er moet gebeuren om die ontwikkeling optimaal te doen verlopen en wat de rol van individuele medewerkers is. Om employability goed in beeld te krijgen en het beleid hierop af te stemmen is inzicht in de behoefte van de organisatie op middellange termijn ( 1 à 3 jaar) onontbeerlijk. De aanwezigheid van goede prognose-instrumenten bepaalt dus ook in zekere mate het mogelijke succes van employability-beleid. Cap Gemini heeft voor dergelijke prognoses een aparte business unit in het leven geroepen, het Cap Gemini Institute.

- 9 Competentiegebieden staan centraal bij functioneringsgesprekken.

- Externe mobiliteit wordt gestimuleerd, omdat het uitzetten van tevreden exwerknemers een gezond netwerk oplevert.

\section{DSM Limburg BV}

- Het eigen Intranet vormt centrum van goed gestructureerd 'stroombeleid', gericht op horizontale en verticale mobiliteit van werknemers.

- In een organisatiebreed verspreide 'Stroomwijzer' worden werknemers gewezen op de mogelijkheden om binnen DSM door te 'stromen'. Bewustmaking van werkenden is hierbij het primaire doel. Inzicht in de mogelijkheden die binnen bedrijven worden geboden ter bevordering van employability, lijkt een belangrijk aandachtspunt.

- DSM toetst ook de tevredenheid onder werknemers over het stroombeleid. 
- Jaarlijkse Loopbaangesprekken hebben betrekking op een viertal gebieden, te weten:

- Vinden er, nu of in de toekomst, veranderingen plaats in je omgeving?

- In hoeverre ben je zelf bereid en in staat je aan te passen, als dat nodig is?

- Hoe breed ben je inzetbaar voor andere taken en functies?

- Wat zijn je wensen, plannen en mogelijkheden voor de toekomst?

- DSM biedt in een Vademecum een uitgebreid overzicht van de instrumenten ter ondersteuning van het stroombeleid. In dit Vademecum wordt een groot aantal instrumenten aangereikt ter facilitering van het werken aan de eigen loopbaan, variërend van 360 -graden-feedback tot sollicitatietraining en van opleidingsadvies tot begeleiding naar de externe arbeidsmarkt.

- Mogelijkheden om tijdelijk iets anders te proberen bestaan.

- Collegiale in- en doorlening.

- Personal coaching.

- Opleidingsafspraken staan centraal in functioneringsgesprekken.

- Alle vacatures die binnen DSM-Limburg ontstaan worden vermeld in de dagelijks opgefriste Vacaturebank, een systeem op het Intranet van DSM. Het systeem biedt alle werknemers de mogelijkheid op vacatures te solliciteren.

- Ook is er op Intranet een Kandidatenbank beschikbaar, een overzicht van werknemers die zich beschikbaar hebben gesteld voor een andere functie. P\&O'ers hebben de mogelijkheid bestanden te matchen.

- Een aantal instrumenten valt onder de noemer Mobiliteitsondersteuning (persoonlijke sterkte/zwakte analyses, loopbaancounseling, management development, Topfit cursus (een cursus waarin men leert de eigen loopbaan te sturen)).

- Ook sollicitatietraining, presentatietrainingen, training op het gebied van persoonlijke effectiviteit, assertiviteit en managerseffectiviteit staan in principe open voor alle DSM'ers.

- Heropvoeding van leidinggevenden, zodat zij oog krijgen voor het belang van employability.

- Outplacement, ondersteuning bij plaatsing extern, begeleiding t.b.v. WSWplaatsing en informatie over de arbeidsmarkt ten slotte geven werknemers ook nog mogelijkheden zich op de externe arbeidsmarkt te oriënteren.

\section{VNO/NCW (AWVN)}

- AWVN ontwikkelde de quick scan, die een aardig beeld oplevert van de positie van bedrijven op de arbeidsmarkt. Uitgangspunten zijn Instroom, Doorstroom en Uitstroom.

- Instroom: gebruikt men effectieve wervingskanalen?, zijn de gevraagde kwalificaties (competenties) helder?, zijn er voldoende sollicitanten van gewenst niveau, imago van onderneming, specifieke doelgroepen, netwerken of samenwerkingsverbanden in de regio, gebruik van onconventionele wervingskanalen (kweekvijver, internet etc.).

- Doorstroom: voldoende doorstroom van tijdelijk naar vaste functies, mobiliteit, inzetbaarheid van werknemers, effectief gebruik van beschikbare arbeidscapaciteit, lengte dienstverband, worden er functioneringsgesprekken gevoerd of is er 
sprake van persoonlijke ontwikkelingsplannen, is de leeftijdsopbouw evenwichtig, horizontale mobiliteit, inventarisatie loopbaanwensen en kan aan die wensen tegemoet worden gekomen, mogelijkheden voor opleiding, interne/externe doorstroom, zijn de werkomstandigheden en het werkklimaat stimulerend, zijn de opgedane vaardigheden specifiek of generiek, wordt aan ervaringsvariatie gewerkt en komt de stijl van leidinggeven de motivatie en brede inzetbaarheid ten goede?

- Uitstroom: ligt het vrijwillig verloop op een acceptabel niveau, is er regelmatig sprake van wegkopen of headhunting van medewerkers, niveau beloning concurrerend, exit-gesprekken?

- De quick scan vormt het startpunt bij het in beeld brengen van de mate waarin bedrijven zich bezighouden met een employability-beleid. Aan de hand van de scan kan worden bepaald in hoeverre sprake is van een probleem, nu of in de nabije toekomst. De Scan vormt dus een interessant instrument bij het in beeld brengen van de effectueringscondities per bedrijfssector. Zeker daar zij op bedrijfsniveau wordt uitgevoerd, zodat individuele bedrijven gemakkelijk zouden kunnen benchmarken.

- VNO/NCW adviseert werkgevers op het gebied van anti-vastloop activiteiten vanuit de gedachte dat ontslagprocedures kostbaar zijn. AWVN organiseert inmiddels ook trainingen op het gebied van employability-management.

- De rol van employability als thema bij CAO onderhandelingen wordt steeds belangrijker. Centraal hierbij staan zaken als multi-inzetbaarheid, overplaatsing, scholing (zie ook: Arbeidsinspectie, 1999a, 1999b en 2000).

\section{CNV}

- CNV heeft in samenwerking met Economische Zaken het 'Op Koers' programma opgezet. Dit programma is erop gericht een meetinstrument voor employability te ontwikkelen. CNV is met de ontwikkeling van dit meetinstrument inmiddels ruim twee jaar bezig en staat op het punt in een groot aantal bedrijven de employability te gaan meten. Omdat de vragenlijsten nog in ontwikkeling zijn is er nog geen expliciet zicht op gebruiksmogelijkheden, maar CNV staat zeker open voor vergaande samenwerking.

- Op Koers bestaat uit drie onderdelen: Bedrijvenvragenlijst (de organisatietoets), Gesprek met P\&O-functionaris en individuele vragenlijsten (de werknemerstoets). Op Koers beoogt met name een beeld van het gevoerde beleid, bekendheid met beleid en tevredenheid over beleid binnen organisaties te geven.

- De Bedrijvenvragenlijst richt zich op instrumenten als taakverrijking, demotie, functieroulatie, promoties, loopbaangesprekken, scholing etc. en de aanwezigheid van dergelijke instrumenten. De vragenlijst peilt zogezegd de effectueringscondities binnen een onderneming.

- Het gesprek met P\&O-functionarissen levert vervolgens een beeld van de manier waarop de instrumenten worden gebruikt. Hierbij wordt bijvoorbeeld ook aandacht besteed aan EVC's (Erkenning van Verworven Competenties), maar het EVCinstrument is nog onvoldoende ontwikkeld om er structureel gebruik van te gaan maken. 
- De individuele vragenlijsten leveren informatie op over wensen en belemmeringen van werknemers ten aanzien van employability. Centrale thema's hierbij zijn tijdsdruk, leiderschapsstijl, collegiale ondersteuning, sociale steun en tevredenheid over de functie.

\section{Agrarische Sector}

- Van belang is het hebben van zicht op toekomstige ontwikkelingen om een goed idee te hebben van vereiste kwalificaties. Door vervolgens uit te gaan van de aanwezige kwalificaties kan de additionele behoefte aan kwalificaties worden ingevuld.

- Van belang is echter ook bewustwording onder werkgevers en werknemers van het feit dat investeren in het menselijk kapitaal van groot belang is.

- Bij het beoordelen van de vereiste kwalificaties en de behoefte aan flexibiliteit maakt men binnen de sector een onderscheid in economische ontwikkelingen met name door veranderende concurrentieverhoudingen, technologische ontwikkelingen in aard, snelheid en intensiteit en ontwikkelingen op het gebied van de wetgeving (ontslagregels).

- Ook scholingsafspraken in CAO's, de mate waarin naar homogene scholing wordt gevraagd binnen de sector, de innovatie en de bedrijfsspecificiteit van de diverse ontwikkelingen vormen aandachtspunten bij het in beeld brengen van employability binnen de agrarische sector.

- Om de employability van individuele werknemers in beeld te brengen wordt gekeken naar leeftijd, scholingsbereidheid, schoolbaarheid en soort dienstverband.

- Ten slotte acht men het cursusaanbod, de aansluiting van school op werk, de beschikbaarheid van gekwalificeerd personeel (de concurrentie op de arbeidsmarkt) en de scholingsinfrastructuur binnen de organisatie van belang.

- De OR van Frico Kaas zoekt naar mogelijkheden om werkzekerheid als beloning te introduceren. Opleidingen en trainingen of taakverrijking zouden dan worden geïntroduceerd als beloningsvormen.

- Veel aandacht voor systematiek van EVC's om ervaringsleren te kwantificeren.

\section{FME/CWM}

- Employability wordt in de Metaal en Elektrotechniek vooral benaderd vanuit een scholingsoptiek.

- Bedrijven storten een percentage van de loonsom in een scholings- en ontwikkelingspot.

- Via indienen van Bedrijfsopleidingsplannen (BOP) kunnen bedrijven zoveel mogelijk van hun bijdrage terugkrijgen. Deze BOP's worden beoordeeld op een drietal centrale criteria: Relatie met ander beleid, doelgroepen, reëel kostenplaatje. De doelgroepen zijn laagopgeleiden, vrouwen en 40-plussers. Bovendien wordt veel aandacht geschonken aan scholing en opleiding op het gebied van veiligheid.

- De opleidingen voor de sector staan in een opleidingscatalogus. 
- Extra beloning voor on-the-job-training is weinig zinvol. OJT is in bijna alle gevallen niet meer dan bijhouden en daarvoor hoeft in principe niet extra te worden beloond.

- Bij het grote aantal middelgrote bedrijven in de metaal en elektrotechniek is door het ontbreken van een P\&O-afdeling vaak weinig aandacht voor de employability van werkenden. De door de sectorale scholingsfondsen gestimuleerde BOP's slaan wel steeds meer aan.

- Naast scholing krijgt flexibilisering de laatste jaren ook de nodige aandacht.

- Vormen van flexibiliteit die binnen de metaal en elektrotechniek worden onderscheiden en die mogelijk van belang zijn bij het in beeld brengen van employability zijn de volgende:

- Flexibele arbeidsduur en werktijden (deeltijdarbeid, flexibel jaarrooster, overwerk, variabele werktijden etc.);

- Flexibele arbeidscontracten (detachering, uitzendarbeid, in- en uitlenen, arbeidspools, thuiswerk etc.);

- Flexibele inzet van arbeid (multi-inzetbaarheid, autonome taakgroepen, uitbesteding etc.);

- Flexibele primaire arbeidsvoorwaarden (prestatiebeloning, winstdeling, belonen van multi-inzetbaarheid, werknemersparticipatie in vermogen);

- Flexibele secundaire arbeidsvoorwaarden (sparen voor verlof, sabbatical, loopbaanonderbreking, pensioenregelingen, cafetaria-systeem).

National Skills Task Force (UK)

Employability spitst zich met name toe op de mate waarin men beschikt over zes 'key-skills':

- Communicatieve vaardigheden;

- Rekenvaardigheid/Wiskunde;

- ICT-skills;

- Probleemoplossend vermogen;

- Teamwork;

- Leervaardigheid. 